\author{
Universidade de São Paulo \\ Escola de Engenharia de São Carlos (EESC) \\ Departamento de Hidráulica e Saneamento \\ Programa de Pós-Graduação em Ciências da Engenharia Ambiental
}

\title{
PROPOSTA DE UM SISTEMA DE AVALIAÇÃO GEOAMBIENTAL PARA RIOS: ESTUDO DE CASO PARA O CÓRREGO DAS CRUZES (SANTO ANTONIO DO ARACANGUÁ/ SP)
}

AUTOR: EDWARDO JOSÉ DE ALBUQUERQUE SOBRINHO ORIENTADOR: PROF. DR. FREDERICO FÁBIO MAUAD

São Carlos

2013 


\author{
Universidade de São Paulo \\ Escola de Engenharia de São Carlos (EESC) \\ Departamento de Hidráulica e Saneamento \\ Programa de Pós-Graduação em Ciências da Engenharia Ambiental
}

Edwardo José de Albuquerque Sobrinho

\title{
PROPOSTA DE UM SISTEMA DE AVALIAÇÃO GEOAMBIENTAL PARA RIOS: ESTUDO DE CASO PARA O CÓRREGO DAS CRUZES (SANTO ANTONIO DO ARACANGUÁ/ SP)
}

Tese de Doutorado apresentada à Escola de Engenharia de São Carlos, da Universidade de São Paulo, como parte dos pré-requisitos para obtenção do título de Doutor em Ciências da Engenharia Ambiental.

Orientador: Prof. Dr. Frederico Fábio Mauad

São Carlos

2013 
AUTORIZO A FEFRODUCAO TOTAL OU FARCLL DESTE TRABALHO POR QUALQUER UEIO COWUENCIONAL OU ELETRONIOO, RARA FIHS DE EGTUDO E FESOUISA, DESDE CUE CITADAA FONTE

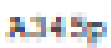

Albuquequ Sobrime, Rdvardo Jond da

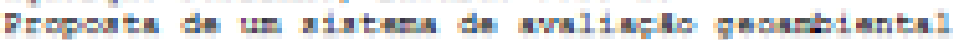

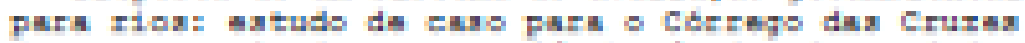

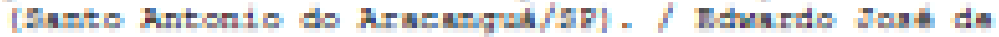

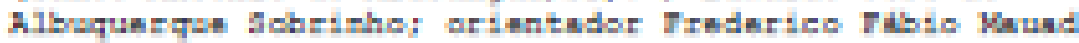

- She carlen, zoiz.

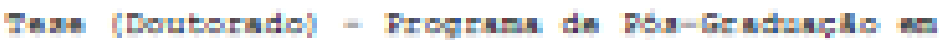

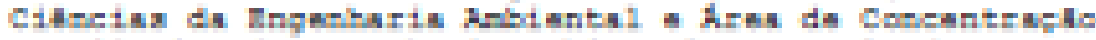

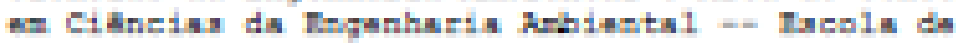

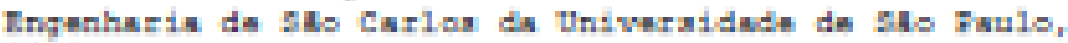
2012.

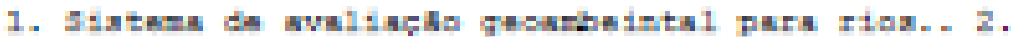

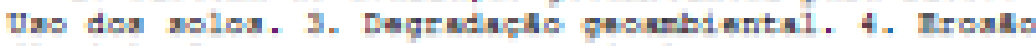

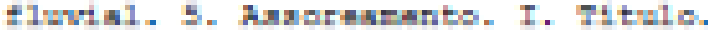




\section{FOLHA DE JULGAMENTO}

Candidato: Bacharel e Licenciado EDWARDO JOSÉ DE ALBUQUERQUE SOBRINHO.

Título da tese: "Proposta de um sistema de avaliação geoambiental para rios: estudo de caso para o Córrego das Cruzes (Santo Antonio do Aracanguá/SP)".

Data da defesa: 04/03/2013

\section{Comissão Julgadora:}

Prof. Dr. Frederico Fabio Mauad (Orientador)

(Escola de Engenharia de São Carlos/EESC)

Prof. Associado Francisco Arthur da Silva Vecchia

(Escola de Engenharia de São Carlos/EESC)

Prof. Titular Jurandyr Luciano Sanches Ross (Faculdade de Filosofia, Letras e Ciências Humanas/USP)

Prof. Dr. Reinaldo Lorandi

(Universidade Federal de São Carlos/UFSCar)

Profe. Drª. Marcia Noélia Eler

(Universidade Federal de São Carlos/UFSCar)
Resultado:
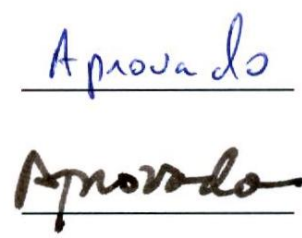

AsnOVIADO
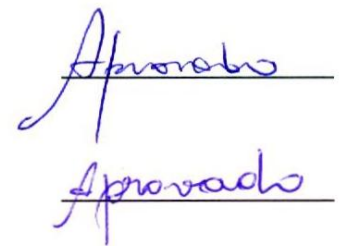

Coordenador do Programa de Pós-Graduação em Ciências da Engenharia Ambiental: Prof. Dr. Frederico Fabio Mauad

Presidente da Comissão de Pós-Graduação:

Prof. Titular Denis Vinicius Coury 
"Mas eu sou como a oliveira verde na casa de Deus; confio na misericórdia de Deus para sempre, eternamente. Para sempre te louvarei, porque tu o fizeste, e esperarei no teu nome, porque é bom diante de teus santos" (Salmos 52: 10-11). 
Dedico esta tese a Deus por tudo que tem feito em minha vida, incluindo os diversos livramentos que tem me dado ao longo de minha existência e pelas pessoas abençoadas que passaram e passam pela minha vida.

Aos meus avós,Maria Marçal dos Santos e Jovino Marcos de Albuquerque Santos, in memorium por terem contribuidos na minha formação pessoal e educacional.

Ao "Lazinho" que muito tem me ajudado, abaixo de Deus, como meu braço direito e esquerdo.

A todos os familiares e amigos que me apoiaram nesta jornada cheia de tribulações, mas superadas e suportadas por Deus.

A todos os "mestres" que passaram em minha vida e contribuíram no que eu sou hoje.

Às minhas "crianças", pela ausência em casa.

Humildemente,

Dedico. 


\section{AGRADECIMENTOS}

Ao poderoso, maravilhoso, misericordioso e único Deus por tudo que tem feito em minha vida, pois com o Senhor. sou mais que vencedor, e nada, nem ninguém vai me separar do meu amor pelo Senhor.

À CAPES pela concessão da bolsa de Doutorado, através do Projeto PróEngenharia NÚMERO PE-029.

Ao Prof. Dr. Frederico Fábio Mauad, por aceitar a orientação desta tese, bem como, disponibilizar os aparatos técnicos existentes para o desenvolvimento da mesma.

À amiga e irmã em Cristo Profa. Dra. Márcia Noéia Éler (UFScar) pelas sugestões e críticas construtivas dadas durante a elaboração do projeto de tese, como também, pelas orações e jejum (pois "O senhor é nosso pastor e nada nos faltará, nem que andemos nas trevas nada temeremos").

À amiga e ex-orientadora Profa. Dr. Helena Polivanov, do Departamento de Geologia da UFRJ, pelas críticas e sugestões dadas. Aprendi muito com a sra. durante o período em que fui seu orientando, durante o mestrado (IGEO/UFRJ). Saudade de suas cobraças e pressões psicológicas. Muito sábias, por sinal. Sou eternamente grato por sua amizade, carinho e criticidade ao meu trabalho. É uma pena que nem todos trabalhem como a ssenhora

À amiga Profa. Dra. Janete Brigante que fraternalmente analisou e teceu críticas construtivas durante a fase final deste trabalho. Sinto-me feliz em tê-la como amiga. Voce é uma das profissionais que conheço que mais possui uma visão holística sobre os ambientes aquáticos. Sou profundamente grato pelo seu socorro, em um momento desesperador da minha vida que, abaixo de Deus, me foi muito, muito importante.

Ao Departamento de Engenharia de Transporte, na pessoa do Prof. Dr. Paulo Cesar Segantine por ceder o engenheiro Paulo Cesar "Paulinho" no levantamento topográfico preliminar da área de estudo.

Ao Departamento de Geotecnia da ESSC/USP, na pessoa do Prof. Dr. Edmundo Rogério Esquivel por ter permitido a realização de parte dos ensaios geotécnicos no citado departamento. 
À engenheira de agrimensura Rosimeire da Silva Neto pela ajuda dada durante a execução do levantamento topográfico preliminar da área de estudo e pelas orações.

Aos técnicos da estação climatológica José Roberto Maramaque "Betão" pelas dúvidas tiradas sobre execução de batimetria e medição de vazão e ao meu amigo André Silva pelo apoio moral durante o desenvolvimento do presente trabalho.

Ao técnico da hidrometria Waldomiro Antonio Filho "Dr. Miro", à Dra. Juliana Moceline e ao engenheiro Diego pela execução do levantamento ecobatimétrico na desembocadura da área de estudo, como também, ao engenheiro André Aukar Britschgy de Camargo pelo apoio dado durante os demais levantamentos topográficos feitos comigo na área de estudo.

Aos técnicos José Luis Guerra e Oscar dos Santos Neto (EESC/ Geotecnia) pelas dúvidas tiradas e ajuda fornecida durante a realização dos ensaios geotécnicos.

Ao Dr. Tadeu e a MSc. América pelos momentos de reflexões sobre o problema da erosão em rios.

Ao "cidão" e à Regina por prepararem nossas refeições no RU da USP/ EESC/ CRHEA, São Carlos, com tanto zelo e carinho, ao longo do tempo que estudei no PPG-SEA.

A todos os funcionários da EESC/USP, em especial: Nelson E. Tessarin, José Luis (secretaria do PPG-SEA) e Mara Lúcia Cotrim Gomes (bibliotecária) pelos serviços prestados com tanto carinho e a atenção a todos os alunos.

Aos trabalhadores tercerizados, que tornam nossos amigos, tornando nosso dia menos penoso. Voces são 1000; em especial a Jô, Suzana, Eduardo, Nilson, Valmir, Ailton, Elisvaldo, Márcio, Viana, Samuel, Ronaldo, Sr. Luiz, Rubens, Clodoaldo.

A todos os colegas, colaboradores e ex-pesquisadores do programa do PPGSEA.

Aos professores membros da banca de tese: Dr. Reinaldo Lorandi (Ufscar), Dr. Jurandir Ross e Dra. Marcia Noélia Eler - pelas críticas e sugestões dadas durante a defesa da tese, em 04/03/2013. 
A minha mãe e a todas as pessoas que se lembraram de mim em suas orações.

Aos irmãos em Cristo que têm orado por mim nesta fase tão difícil da minha vida, de muita luta, tribulação e perseguições de natureza diversa. Só Deus e meus irmãos em Cristo sabem o que passei.

Ao Edson Dorneles pela correção ortográfica da tese. Abençoada ajuda.

A todos os "mestres" que passaram em minha vida e plantaram a semente do conhecimento.

A todos que contribuiram diretamente e indiretamente para a materialização do fruto de anos de estudo, trabalho, dedicação e fé no Altíssimo, pela perseverança e fé em Deus, nosso único Criador e Salvador (Testemunho de fé e adoração a Deus: Pai, Filho e Espírito Santo).

Muito, muito obrigado por tudo, ofereço profunda gratidão. 


\section{Resumo}

Albuquerque Sobrinho, E. J. de. Proposta de um sistema de avaliação geoambiental para rios: estudo de caso para o Córrego das Cruzes (Santo Antonio do Aracanguá/ SP). São Carlos-SP, 2013. 230f. Tese (Doutorado) Escola de Engenharia de São Carlos. Universidade de São Paulo, São Carlos, 2013.

Os rios, enquanto produtos da interação entre os agentes internos e externos da Terra, são elementos da paisagem em constante mutação ao longo do tempo e do espaço, sujeitos aos fenômenos da erosão e da sedimentação (assoreamento). Contudo, o homem ao interagir de forma negligente com o meio, no caso, os diferentes cursos de água, intensifica o processo natural de degradação ambiental. Estes impactos variam de lugar para lugar, em função de diferentes fatores, dentre eles o clima, o tipo de solo, resistência geomecânica dos materiais, condições geomorfológicas e estruturais da drenagem, entre outros.

Por conta disto, este trabalho propõe um sistema de avaliação geoambiental para rios, cuja aplicação ocorreu em um curso d'água de segunda ordem, localizado na porção noroeste do Estado de Estado de São Paulo, com área de $7,81 \mathrm{~km}^{2}$. $\mathrm{O}$ desenvolvimento deste sistema deu-se a partir da compartimentação de sete grupos distintos (Climático, geomorfológico, geológico, hidráulico, físico-químico para água e sedimentos, biológico e uso e ocupação, contendo 33 parâmetros). A atribuição dos pesos teve como base, o potencial que uma determinada variável tem em contribuir no processo degradação ambiental, vista isoladamente mas integrada ao sistema classificatório em questão. No caso de existir limites apoiados pela comunidade científica, os mesmo foram adotados, embora a forma de apresentação dos mesmos foi adaptada à lógica adotada nesta tese. Vale ressaltar que o limite atribuído para cada variável apresentou valores distintos, onde o menor valor foi atribuído, como sendo peso 1 (muito estável) e máximo de peso 9 (muito instável), onde quanto menor a pontuação, melhor a classificação. Após a definição dos pesos, foram delimitados cinco intervalos de classes distintos, cujos valores das classificação - natural, alterado e degradado - partiram do somatório de todas 
variáveis agrupadas por pontuação (natural $=\Sigma$ peso $<5$; alterado $=\Sigma$ peso 5-7; degradado $=\Sigma$ peso $>8$ ). Intermediariamente a estas classes, foram definidas as subclasses cujos valores estivessem entre os limites atribuídos pelas classes (levemente alterado $=84-141$ pontos e muito alterado $=194-234$ pontos. Os resultados apresentados pelo conjunto de dados expostos separadamente foram satisfatórios, pois permitiram compreender a correlação entre as condições geoambientais e a participação destas no processo de degradação ambiental, onde conclui-se que o Córrego das Cruzes possui características que o torna susceptível à erosão, especialmente no que diz respeito as condições pedológicas e geotécnicas, ademais que a constituição topográfica (morfologia da drenagem) por meio da inclinação das vertentes propicia processos erosivos como tombamento, erosão marginal e feições lineares (erosão linear, ravinas e voçorocas).

As diferentes abordagens relacionadas à análise ambiental (técnicas investigativas em geociências), , podem ser empregadas, embora possuam limitações entre si como a comparação do objeto de estudo apontando os agentes causadores do processo de degradação do ambiente. No caso em questão, trata-se de um córrego localizado no interior do Estado de São Paulo que padece de problemas diversos. Através do sistema de avaliação proposto e da comparação dos resultados obtidos pelo mesmo, com técnicas investigativas vigentes, conclui-se que: 1) Apesar da difusão destas técnicas no meio acadêmico e técnico, as mesmas mostraram-se ineficientes para inserir o fator social como agente causador de perturbações ambientais, já que o homem/sociedade exerce um agressivo papel como deflagrador ou facilitador da degradação ambiental nos diversos ambientes/ecossistemas; 2) na abordagem feita pelos parâmetros morfométricos, a mesma tem um papel extremamente físico do ambiente fluvial, sendo adequado seu emprego no caso de um determinado curso d'água sofrer influência dos elementos geomorfológicos e geológicos, e; 3) a cartografia temática de cunho geológicogeotécnico é uma importante ferramenta avaliativa, embora seja um pouco limitada por questões que transcendem ao arcabouço teórico e geológico-geotécnico, seja ele baseado em dados de campo e/ou investigados por meio de ensaios laboratoriais. Neste sentido, o uso combinado destas técnicas, como o sistema de 
avaliação em foco, teve um papel importante para corroborar os dados do meio físico e demais variáveis expostas.

O Sistema de Avaliação Geoambiental mostrou-se flexível quanto às diferentes combinações de problemas de natureza sócio-econômico-ambiental, apesar de ter um significativo número de variáveis que permitem "descobrir" ou mesmo apontar o(s) agente(s) transformador(es) do meio; pelo menos nas variáveis que comumente ocorrem; apesar de que as ações caóticas não tenham sido colocadas neste sistema, a fim de não dificultar a aplicação por parte de pessoas de outras áreas da ciência, no caso destas utilizarem esta ferramenta. Devido ao fato deste sistema ser de cunho quali-quantitativo, o conjunto de parâmetros aqui proposto, seguido de suas variáveis, facilita comparar rios de natureza distintas, como se fossem uma forma de "check list". Os documentos cartográficos foram realizados em estaca distinta, visando expor os dados levantados de forma global (1: 10.000) e de detalhe (1: 2.500), conforme a técnica de detalhamento progressivo.

Palavras Chaves: Sistema de Avaliação de erosão de rios, uso dos solos, degradação geoambiental, erosão fluvial, assoreamento. 


\begin{abstract}
Albuquerque Sobrinho, E. J. de. Proposal of a geoenvironmental evaluation system for rivers: study of case for Córrego das Cruzes stream (Santo Antonio do Aracanguá/ SP). São Carlos-SP, 2013. 227f. Tese (Doutorado) - Escola de Engenharia de São Carlos. Universidade de São Paulo, São Carlos, 2013.
\end{abstract}

The rivers, as products of interaction between internal and external earth agents are landscape elements constantly changing during the time, and they are subject to the erosion and sedimentation (siltation) phenomena. However, the mankind negligently when interacting with the environment, in this case, the different streams, it enhances the natural process of environmental degradation. These impacts vary from place to place, depending on different factors, including climate, soil type, strength of materials geomechanics, structural and geomorphological conditions of drainage, etc. Due to these factors, the present PHD Thesis proposed a system of geoenvironmental assessment for rivers, to make this task more simple, where it was tested on stream of $1^{\text {st }}$ order, located in the northwestern portion of the State of São Paulo, with $7,81 \mathrm{~km}^{2}$ of area. This system was partitioned on seven distinct groups (climatic, geomorphological, geological, hydraulic, physical-chemical water and sediment, biological, and use and occupancy) totalizing 33 parameters. The assignment of weights based on the potential that a particular variable contributes to the erosion or correlated with this environmental problem. It is noteworthy that the limit was adopted for each variable from 1 (very stable) to 10 (very unstable). After the scores definition, five distinct classes' intervals were limited, which values of classifications: natural, modified and degraded, came from sum of all variable grouped by punctuation (natural $=\Sigma$ score $<5$; modified $=\Sigma$ score $5-7$; degraded $=$ $\Sigma$ score $>8$ ). Between these classification, two subclasses were defined (slightly altered $=84-141$ points e very altered $=194-234$ points. The results presented by the set of data were satisfactory. It was because of their ability of understanding geoenvironmental features and their participation on the environmental degradation process. It was concluded that the stream in focus has aspects that present it high susceptibility to erosion, especially regarding soil and geotechnical conditions, not to 
mention that the constitution topographic (drainage morphology) by means of the inclination of the slopes and tipping provides erosion, bank erosion and the linear (linear erosion, ravines and gullies). The different approaches related to environmental analysis (geosciences investigation techniques), although they have limitations between them, they could be employed, besides the difficult of comparison to different rivers and hability to indicate the main degradation agents, in this case, a stream located within the State of Sao Paulo/Brazil that has serious environmental problems. Through the proposed evaluation system and comparison of obtained results by some of existing investigation techniques, it concluded that: 1) Despite the spread of these techniques in the academic and technical environment, they proved to be inefficient to insert the social factor as causative an environmental perturbations agent, since man / society plays an aggressive role as a trigger off or facilitator of environmental degradation in different ecosystems; 2) the approach taken by the morphometric parameters, it plays a physical perspective of river environment and its use is more appropriated for water course under influence of geomorphologic and geological elements, and 3) the thematic mapping of geotechnical focus is an important evaluative tool, although it is somewhat limited by issues that transcend geological and geotechnical field, even if it is based on field data and / or tested on laboratorial analysis. In this direction, the combination of different tools, as a system of evaluation focus, played an important role to corroborate the data of the physical environment with the other variables exposed. The Geoenvironmental Evaluation System proved to be flexible about different combinations of socio-economic and environmental problems, although a significant number of variables that allows you to find out agent(s) modifiers of environment, at least the most usual variables that occur, although chaotic actions have not been placed on this system, in order not to hamper the implementation by people from other areas of science, if they try to apply this technique. Due the nature of the proposition technique (qualitative and quantitative tool), the set of parameters proposed here and followed by its variables, facilitate to compare rivers of different nature, like a form of "check list". Cartographic documents were made on different scales to express data survey on global aspects (1: 10.000) and detailed (1: 2.500), according to the Progressive Detailing Technique. 
Key-words: Assessment of rivers erosion system, soil uses, environmental degradation, river erosion. 


\section{SIGLAS E ABREVIAÇÕES}

ABNT - Associação Brasileira de Normas Técnicas

ANA - Agência Nacional de Águas

ANEEL - Agência Nacional de Energia Elétrica

AQEM - Integrated Assessment System for the Ecological Quality of streams and

Rivers throughout Europe using Benthic Macroinvertebrates

CAD - Computer Aided Design

CETESB - Companhia Estadual de Tecnologia de Saneamento Ambiental

$\mathrm{CRH}$ - Conselho Estadual de Recursos Hídricos

CTCG - Comissão Técnica de cartografia geotécnica e geoambiental

DAEE - Departamento de Águas e Energía Elétrica

DGPS - Sistema de Posicionamento Global Diferencial

DLWC - Department of Land e Water Conservation

DNPM - Departamento Nacional de Produção Mineral

EESC - Escola de Engenharia de São Carlos

GIS - Geographical Information System

GNSS - Global Navigation Satellite System

GPR - Ground Penetration Radar

GPS - Sistema de Posicionamento Global

IAEG - International Association Engineering Geology

IBGE - Instituto Brasileiro de Geografia e Estatística

ILWIS - Integrated Land and Water Information Systems

IPEN - Instituto de Pesquisas Enérgetica e Nucleares

IPT - Instituto de Pesquisa Tecnológica

LiDAR - Light Detection and Ranging

LWA - Land \& Water Australia

MMA - Ministério do Meio Ambiente

NSW - New South Wales

PMP - Ponto de Murchamento Permanente

PNUMA - Programa das Nações Unidas para o Meio Ambiente

RHB - Região Hidrográfica Brasileirs 
RUSLE - Revised Universal Soil Loss Equation

SBCS - Sociedade Brasileira de Ciência do Solo

SIG - Sistema de Informação Geográfica

SIGRH - Sistema Integrado de Gestão de Recursos Hídricos

SMR - Slope Mass Rating

SPT - Standard Penetration Test

SWAT - Soil and Water Assessment Tool

TFSE - Terra fina seca ao ár

THMs - Trialometanos

UFC - Universidade Federal do Ceará

UFF - Universidade Federal Fluminense

UFRJ - Universidade Federal do Rio de Janeiro

UGRHI - Unidades Hidrográficas de Gerenciamento de Recursos Hídricos

UHE - Usina Hidrelétrica

UNESP - Universidade Estadual Paulista

USLE - Universal Soil Loss Equation

USP - Universidade de São Paulo

WFD - Water Framework Directive

ZCAS - Zona de Convergência do Atlântico Sul

ZCIT - Zona de Convergência Inter-tropical 


\section{Lista de Figuras}

Figura 1 - Localização espacial da área de estudo (Fonte: Adaptado de Google, 2009 \& CBH-BT, 2009).

Figura 2 - Distribuição climática do Estado de São Paulo pelo sistema de Köppen (adaptado de SETZER, 1966 apud ROLIM et al. 2007).

Figura 3 - Fatores que enflunciam no vale cruzado (adaptado em WARN, 2011)

Figura 4 - As diferentes variações das formas das vertentes (adaptado de TROEH, 1965 apud ARAUJO, 2011). .29

Figura 5 - Classificação taxonômica das diversas formas de relevo (ROSS, 1992)

Figura 6 - Presença de nascente influenciando na degradação do solo (Autor: E. J. Albuquerque Sobrinho). .32

Figura 7 - Gráfico textural do solo (VIEIRA, 1988) 36

Figura 8 - Exemplo de intervenção geotécnica para estabilização e reforço de maciço com via (Autor: E. J. Albuquerque Sobrinho).

Figura 9 - Tipos de estruturas existentes nos diferentes horizontes dos solos (SBCS, 1982; VIERIA, 1988). 63

Figura 10 - Aplicação do potencial de recuperação do framework para vale parcialmente confinado com leito rochoso com descontinuidade controlada do River Style da planície de inundação (BRIERLEY et al., 2002).

Figura 11 - Feição erosiva do tipo ravina, na margem esquerda do Córrego das Cruzes (Autor: E. J. Albuquerque Sobrinho). .94

Figura 12 - Uso da área para pastagem em janeiro de 2011 (Autor: E. J. Albuquerque Sobrinho). 
Figura 13 - Carta geológica do Córrego das Cruzes (Santo Antônio do Aracanguá, SP).

Figura 14 - Planta geológica do Córrego das Cruzes (Santo Antônio do Aracanguá, SP): Folhas 1, 2, 3 e 4.

Figura 15 - Carta dos materiais geológicos do Córrego das Cruzes (Santo Antônio do Aracanguá, SP). 98

Figura 16 - Planta dos materiais geológicos do Córrego das Cruzes (Santo Antônio do Aracanguá, SP): Folhas 1, 2, 3 e 4 .99

Figura 17 - Planta dos problemas geotécnicos do Córrego das Cruzes (Santo Antônio do Aracanguá, SP), Folhas 1, 2, 3 e 4 100

Figura 18 - Carta dos problemas geotécnicos do Córrego das Cruzes (Santo Antônio do Aracanguá, SP). 101

Figura 19 - Componentes do sistema de avaliação proposto. 102

Figura 20 - Equipamentos utilizados no levantamento plani-altimétrico da área de estudo: $a$ = Estação total; b=prisma óptico e tripé (Autor: E. J. Albuquerque Sobrinho). 104

Figura 21 - Preparação dos equipamentos utilizado no levantamento ecobatimétrico no contato córrego/ribeirão das Cruzes (Autor: E. J. Albuquerque Sobrinho). 105

Figura 22 - Distribuição espacial das seções topobatimétricas (Fonte: Google Earth, 2012). 106

Figura 23 - Software utilizado na elaboração das curvas de nível (Surfer 6.04). 107

Figura 24 - Molinete usado na medição de vazão (Autor: André Aukar Britschgy de Camargo). 108 
Figura 25 - Equipamentos utilizados na definição da quantidade de materia orgânica dos solos (Autor: E. J. Albuquerque Sobrinho).

Figura 26 - Localização dos pontos de amostragem do teor de matéria orgânica dos materiais geológicos da área de estudo (Fonte: Google Earth, 2012).

Figura 27 - Coleta de amostra em duplicata para definição do teor de sólidos em suspensão (Autor: E. J. Albuquerque Sobrinho) 113

Figura 28 - Equipamento utilizado no processo de filtragem das amostras de campo (Autor: E. J. Albuquerque Sobrinho).

Figura 29 - Modelo de infiltrômetro usado na área de estudo (adaptado de GUERRA, 2001).

Figura 30 - Localização do antigo reservatório que se rompeu no interior do Córrego das Cruzes (Autor: E. J. Albuquerque Sobrinho).

Figura 31 - Vista do segundo reservatório que se rompeu ao longo do Córrego das Cruzes (Autor: E. J. Albuquerque Sobrinho). 120

Figura 32 - Locais utilizados na investigação da permeabilidade do solo (Auto: E. J. Albuquerque Sobrinho). 129

Figura 33 - Afloramento de areníto biotítico (a) e remobilização do fundo e transporte por rolamento do material mais grosseiro (b) (Auto: E. J. Albuquerque Sobrinho). 130

Figura 34 - Vista da desembocadura direita (Autor: E. J. Albuquerque Sobrinho). 134

Figura 35 - Estratificações formadas pela interação hidrodinâmicas nas proximidades da desembocadura do Córrego das Cruzes com o ribeirão de mesmo nome (Autor: E. J. Albuquerque Sobrinho). 134

Figura 36 - Vista da desembocadura direita (perene) ao fundo o Ribeirão das Cruzes (Autor: E. J. Albuquerque Sobrinho). 138 
Figura 37 - Distribuição espacial dos pontos investigados pelo Sistema de Avaliação Geoambiental em proposição (Fonte: Google Earth, 2012).

Figura 39 - Uma das áreas usadas pelo gado para acesso ao Córrego das Cruzes (a) e degradação das margens pelo pisoteio do gado (b). 175

Figura 39 - Vista da desembocadura esquerda sob período de estiagem (a) e em escoamento causado durante a quadra chuvosa (b). 182

Figura 40 - Vista da área localizada próxima aos pontos de controle 19 e 20 (Autor: E. J. Albuquerque Sobrinho). 183

Figura 41 - Vista da manilha localizada entre os pontos 16 e 17 (Autor: E. J. Albuquerque Sobrinho). 185

Figura 42 - Ponto de estudo com maior pontuação total - Estação 6 (Autor: Google Earth; E. J. Albuquerque Sobrinho). 188

\section{Lista de Gráficos}

Gráfico 1- Variação do volume de infiltração ao longo da área de estudo......129

Gráfico 2 - Valores referentes à média e desvio padrão dos Protocolo de Avaliação de Rápidos). 135

Gráfico 3 - Variação percentual do teor de matéria orgânica dos materiais geológicos da área de estudo. 175

Gráfico 4 - Distribuição da pontuação total do Sistema de Avaliação Geoambiental 178

Gráfico 5 - Variação das propriedades Geomorfológicas da área de estudo com base no Sistema de Avaliação Geoambiental. 180 
Gráfico 6 - Variação das propriedades hidráulicas da área de estudo com base no Sistema de Avaliação Geoambiental.

Gráfico 7- Variação das propriedades geotécnicas da área de estudo com base no Sistema de Avaliação Geoambiental. 183

Gráfico 8 - Variação das propriedades ecológicas da área de estudo com base no Sistema de Avaliação Geoambiental. 184

Gráfico 9 - Variação das propriedades relacionadas ao uso e ocupação ao longo da área de estudo com base no Sistema de Avaliação Geoambiental. 186

\section{Lista de Tabelas}

Tabela 1 - Exemplos das diferentes abordagens adotadas no estudo do problema da erosão em ambientes fluviais comumentes adotados.

Tabela 2 - Fatores que influem na suscetibilidade à erosão dos solos (adaptado de LAL, 1990 apud de LIMA, 2003) 14

Tabela 3 - Processos erosivos e seus impactos ambientais em áreas críticas brasileiras (Adaptado de BOTELHO \& GUERRA, 2003). 20

Tabela 4 - Definições os diferentes tipos de solos (MACIEL FIHO, 1994; IBGE, 2007)

Tabela 5 - Comparação entre áreas de bacias hidrográficas distintas e seus respectivos comprimentos (adaptado de MEADE et al. 1979; CHRISTOFOLETTI, 1983; MANABE \& VESEROLD, 2003; SHIKLOMANOV, 2003; GOULDING; BARTHEM; FERREIRA et al., 2003 apud MARTINEZ et al., 2009; MIKHAILOV, 2010; CARVALHO et al.; 2010). 32

Tabela 6 - Capacidade de campo para diferentes texturas do solo (adaptado de SOUSA PINTO, 1976). .35 
Tabela 7 - Características das texturas dos materiais geológicos sob diferentes parâmetros geotécnicos (adaptados de YOSHIZANE, 2005).

Tabela 8 - Impactos ambientais causados pelo uso diferenciado do solo na cidade de São Carlos/SP (PONS \& PEJON, 2008). 50

Tabela 9 - Ativades potencialmente poluidoras do Rio Mogi-Guaçu (MOTA, 1975; BRAILE \& CAVALCANTE, 1979; CETESB, 1999 apud ESPÍNDOLA; BRIGANTE; ELER, 2003). 52

Tabela 10 - Principais impáctos ambientais nos diferentes métodos de lavra que geram impáctos diretos nos ambientes fluviais (adaptado de FERREIRA, 2011). .54

Tabela 11 - Problemas ambientais vigentes nas regiões hidrográficas brasileiras (PNUMA, 2007). 55

Tabela 12 - Práticas que podem ser utilizadas na melhoria do solo e minimização dos impactos causados ao solo (ZOCCAL, 2007).

Tabela 13 - Propriedades físicas e morfológicas dos solos (adaptado de VIEIRA, 1988). 64

Tabela 14 - Variação entre os tamanhos das estruturas (adaptado de IBGE, 2007) 65

Tabela 15 - Capacidade de campo para diferentes texturas do solo (adaptado de SOUSA PINTO, 1976) 66

Tabela 16 - Características das texturas dos materiais geológicos sob diferentes parâmetros geotécnicos (adaptados de Yoshizane, 2005).

Tabela 17 - Descrição dos parâmetros morfométricos e suas fórmulas (SHERMAN, 1932; HORTON, 1945; STRAHLER, 1964; MELTON; 1957; VERSTAPPEN, 1983; PATTON, 1988; RITTER et al., 1995; BISWAS et al., 1999; MACKA, 2001; REDDY et al., 2004 apud OZDEMIR \& BIRD, 2009) .79 
Tabela 18 - Continuação da descrição dos parâmetros morfométricos (SHERMAN, 1932; HORTON, 1945; STRAHLER, 1964; MELTON; 1957; VERSTAPPEN, 1983; PATTON, 1988; RITTER et al., 1995; BISWAS et al., 1999; MACKA, 2001; REDDY et al., 2004 apud OZDEMIR \& BIRD, 2009).

Tabela 19 - Protocolo de Avaliação Rápida da Diversidade de Habitats em trechos de bacias hidrográficas, modificado do protocolo da Agência de Proteção Ambiental de Ohio (EUA) (EPA, 1987). (Obs.: 4 pontos (situação natural), 2 e 0 pontos (situações leves ou severamente alteradas). 82

Tabela 20 - Protocolo de Avaliação Rápida da Diversidade de Habitats em trechos de bacias hidrográficas, modificado do protocolo de Hannaford et al. (1997). (Obs.: 5 pontos (situação natural), 3, 2 e 0 pontos (situações leve ou severamente alteradas). .83

Tabela 21 - Continuação da tabela 60: Protocolo de Avaliação Rápida da Diversidade de Habitats em trechos de bacias hidrográficas, modificado do protocolo de Hannaford et al. (1997). (Obs.: 5 pontos (situação natural), 3, 2 e 0 pontos (situações leve ou severamente alteradas).

Tabela 22 - Distribuição dos pontos do Protocolo de Avaliação de Rápidos (adaptado de Callixto et al., 2002; XAVIER \& TEIXEIRA, 2007). .86

Tabela 23 - Propriedades morfológicas dos materiais pedológicos das vertentes (SBCS, 1982) 109

Tabela 24 - Variação das propriedades morfológicas dos diferentes materiais geológicos da área de estudo.

Tabela 25 - Teor dos sólidos em suspensão da área de estudo. 127

Tabela 26 - Distribuição granulométrica dos materiais geológicos da área de estudo. 131

Tabela 27 - Distribuição geral da pontuação do Protocolo de Avaliação de Rápidos (EPA, 1981). 136 
Tabela 28 - Descrição dos parâmetros morfométricos da área de estudo.....137

Tabela 29 - Tipo climático local (KÖPPEN \& GEIGER, 1928 apud PEEL; FINLAYSON; MCMAHON, 2007). 144

Tabela 30 - Tipo climático local - Köppen-Geiger (PEEL; FINLAYSON; MCMAHON, 2007). 145

Tabela 31 - Temperatura média - Köppen-Geiger (PEEL; FINLAYSON; MCMAHON, 2007)

Tabela 32 - Pontuação Parcial dos parâmetros climáticos. 147

Tabela 33 - Natureza do substrato 147

Tabela 34 - Tipos de solos 149

Tabela 35 - Pontuação Parcial dos parâmetros geológicos 150

Tabela 36 - Tipos de vales fluviais 150

Tabela 37 - Tipologia fluvial e suas características distintas (adaptado de DOEGLAS, 1962; CUNHA \& GUERRA, 1996; AHMED \& FAWZI, 2009; BARROS; RAPOSO; MAGALHÃES JÚNIOR, 2009; WARN, 2011) 151

Tabela 38 - Grau de Inclinação (EMBRAPA, 1979). 151

Tabela 39 - Tipo de vertentes (adaptado de NBR 11682, 2006). 152

Tabela 40 - Pontuação Parcial dos parâmetros geomorfológicos. 152

Tabela 41 - Tipo de regime 153

Tabela 42 - Vazão $\left(\mathrm{m}^{3} / \mathrm{s}\right)$ 153

Tabela 43 - Ocorrência de nascente. 154

Tabela 44 - Sólidos em suspensão (\% de sedimento/ 500ml) 155

Tabela 45 - Pontuação Parcial dos parâmetros hidráulicos. 155

Tabela 46 - Textura dos solos (granulometria) 
Tabela 47 - Permeabilidade dos solos (adaptado de STANCATI; NOGUEIRA; MONJEVILAR, 1981 apud LORANDI et al., 2001).

Tabela 48 - Teor de matéria orgânica dos solos.

Tabela 49 - Grau de Saturação dos materiais geológicos (adaptado de IAEG, 1979) 158

Tabela 50 - Problemas geotécnicos 159

Tabela 51 - Pontuação Parcial dos parâmetros geotécnicos. 159

Tabela 52 - Faixa marginal (mata ciliar) 160

Tabela 53 - Característica da faixa marginal (mata ciliar) 160

Tabela 54 - Aspecto vegetacional da mata ciliar. 161

Tabela 55 - Tipo de vegetação na drenagem (fixação ao leito) 161

Tabela 56 - Cobertura do solo da mata cilitar. 162

Tabela 57 - Pontuação Parcial dos parâmetros ecológicos 162

Tabela 58 - Infra-estruturas públicas e privadas 163

Tabela 59 - Tipo de uso e ocupação 164

Tabela 60 - Valores da massa, área do casco e pressão de animais (adaptado de SOUSA et al., 1998 apud SOUSA et al., 1998). 165

Tabela 61 - NÚMERO de animais por hectare. 166

Tabela 62 - Tipo de pastagem. 166

Tabela 63 - Planejamento do uso do solo. 167

Tabela 64 - Infra-estruturas pra controle de erosão 167

Tabela 65 - Tipo de Manejo (VIEIRA et al., 1996; BANCO DO NORDESTE, 1999; BERTONI \& LOMBARDI NETO, 1999;). 168 
Tabela 66 - Localização do cultivo agrícola na planície fluvial.

Tabela 67 - Tipo de cultura (adaptado de BERTONI \& LOMBARDI NETO, 1999; PONS, 2006 apud CEREDA JUNIOR, 2006).

Tabela 68 - Pontuação Parcial dos parâmetros relacionados ao uso e ocupação.

Tabela 69 - Pontuação adotada para a classificação paramétrica do curso d'água

Tabela 70 - Proposta de classificação final baseada na pontuação obtida após sua aplicação por segmento.

Tabela 71 - Dados provenientes do ensaio de infiltração. 176

Tabela 72 - Tipo climático local (Köppen-Geiger). 252

Tabela 73 - Tipo climático local - Köppen-Geiger (PEEL; FINLAYSON; MCMAHON, 2007).

Tabela 74 - Temperatura média - Köppen-Geiger (PEEL; FINLAYSON; MCMAHON, 2007)

Tabela 75 - Natureza do substrato

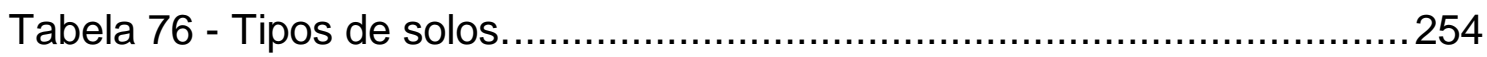

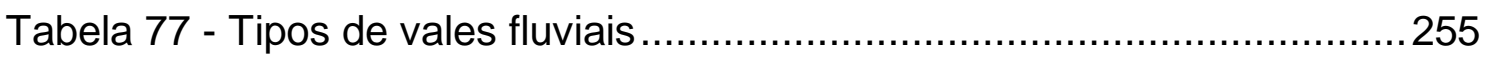

Tabela 78 - Tipo de canal fluvial. ..............................................................25

Tabela 79 - Grau de Inclinação do terreno (EMBRAPA, 1979). .....................255

Tabela 80 - Tipo de vertentes (adaptado de NBR 11682, 2006)..................256

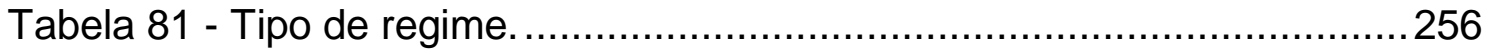

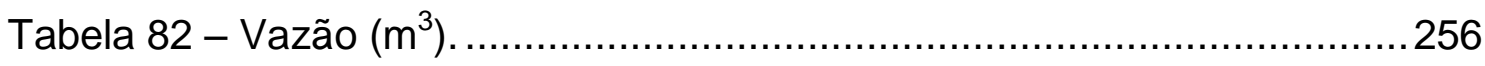

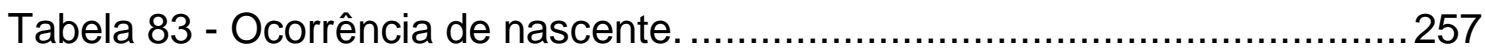


Tabela 84 - Sólidos em suspenção (\% de sedimento/ 500ml)

Tabela 85 - Textura dos solos (granulometria). 258

Tabela 86 - Permeabilidade dos solos (adaptado de STANCATI; NOGUEIRA; MONJEVILAR, 1981 apud LORANDI et al., 2001). 258

Tabela 87 - Teor de matéria orgânica dos solos. 258

Tabela 88 - Grau de Saturação (adaptado de IAEG, 1979) 259

Tabela 89 - Problemas geotécnicos. 259

Tabela 90 - Faixa marginal (mata ciliar) 260

Tabela 91 - Característica da faixa marginal (mata ciliar) 260

Tabela 92 - Aspécto vegetacional da mata ciliar. 260

Tabela 93 - Tipo de vegetação na drenagem (fixação ao leito) 260

Tabela 94 - Cobertura do solo da mata cilitar. 260

Tabela 95 - Infra-estruturas públicas e privadas 261

Tabela 96 - Tipo de uso e ocupação .261

Tabela 97 - Tipo de animal Valores da massa, área do casco e pressão de animais do Vale do Pajeú, em Pernambuco (adaptado de SOUSA et al., 1998 apud SOUSA et al., 1998). 262

Tabela 98 - $\mathrm{N}^{\circ}$ de animais por hectare. 262

Tabela 99 - Tipo de pastagem. 263

Tabela 100 - Planejamento do uso do solo. .263

Tabela 101 - Infra-estruturas pra controle de erosão .263

Tabela 102 - Tipo de Manejo (VIEIRA et al., 1996; BERTONI \& LOMBARDI NETO, 1999). 263 
Tabela 103 - Localização do cultivo agrícola na planície fluvial.

Tabela 104 - Tipo de cultura (adaptado de BERTONI \& LOMBARDI NETO, 1999; PONS, 2006 apud CEREDA JUNIOR, 2006). 264

Tabela 105 - Somatório total da pontuação para classificação final do curso d'água. 265

Tabela 106 - Ensaio de granulometria dos materias geológicos da área de estudo. 266

Tabela 107 - Variação da capacidade de infiltração da área de estudo. 268

Tabela 108 - Variação dos dados de campo baseados no Sistema de Avaliação Geoambiental. 270 


\section{SUMÁRIO}

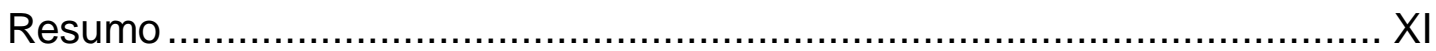

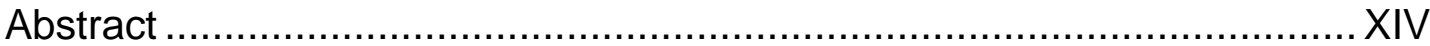

SIGLAS E ABREVIAÇÕES................................................................ XVII

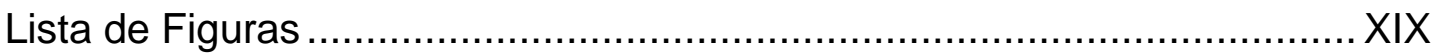

Lista de Tabelas ................................................................................

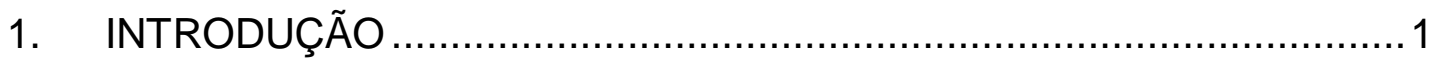

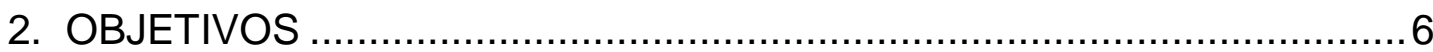

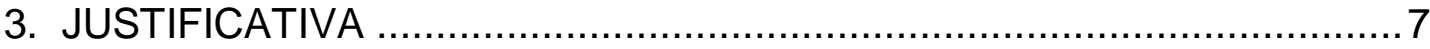

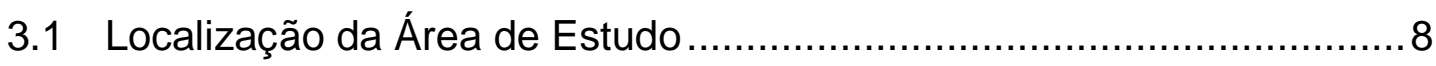

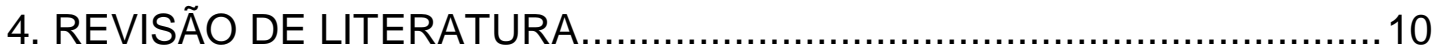

4. 1 Abordagens utilizadas em estudos de erosão e suas múltiplas escalas

4. 2 Variáveis que influenciam na degradação dos rios e de seu entorno ..

4.2.1 O clima como agente modelador do terreno..................................16

4.2.2 Condicionantes geológicos indutores da erosão ………………....21

4.2.3 Parâmetros geomorfológicos dos problemas geotécnicos ocorrentes em áreas em erosão

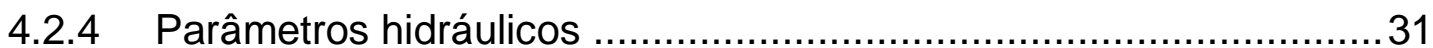

4.2.5 Parâmetros pedológicos e geotécnicos ..........................................33

4.2.5.1 Problemas geotécnicos ocorrentes em rios e em suas margens. 38 4.2.6 Parâmetros Ecológicos Relacionados aos Processos de Erosão ....41 
4.2.7 Uso e ocupação do solo

4.3 Propriedades pedológicas (físicas e morfológicas) ………………....... 62

4.4 Sistemas de avaliação da qualidade dos ambientes fluviais ................67

4.4.1 The River Styles Framework (NSW \& DLWC)...............................72

4.4.2 Análise Morfométrica dos Ambientes Fluviais ...............................74

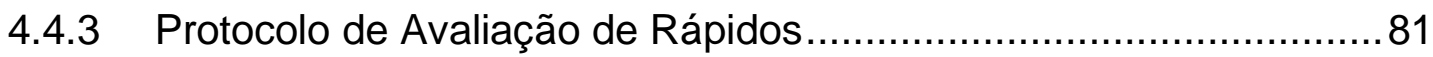

5. CARACTERIZAÇÃO FISIOGRÁFICA DA ÁREA DE ESTUDO ............88

5.1 Caracterização regional do Meio Físico................................................ 88

5.2 Caracterização geoambiental do Córrego das Cruzes ........................92

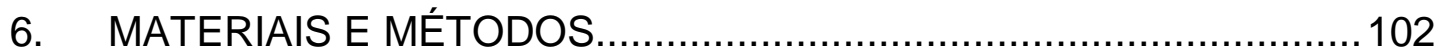

6.1 Levantamento Topográfico e Topobatimétrico por Estação Total .......103

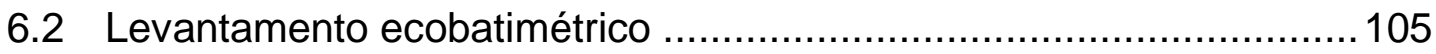

6.4 Representação das curvas de nível e das isópatas ...........................107

6.5 Medição de Vazão por Molinete …………………..........................108

6.6 Caracterização morfológica dos depósitos consolidados e

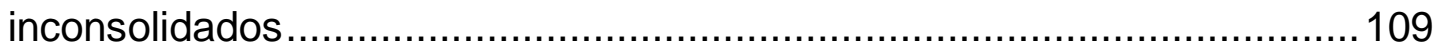

6.7 Caracterização granulométrica e textural da área de estudo ..............110

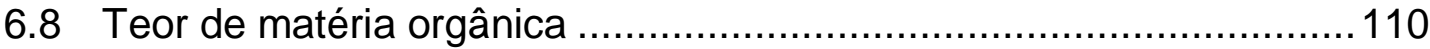

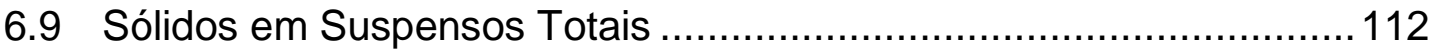

6.10 Medição de infiltração do solo ..................................................114

6.11 Mapeamento Geológico-geotécnico por Detalhamento Progressivo ... 116

7. AVALIAÇÃO DA ÁREA DE ESTUDO POR TÉCNICAS DISTINTAS. 118

7.1 Abordagem geológico-geotécnico de avaliação ambiental em ambiente fluvial 118

7.1.1 Caracterização geológica. 118 
7.1.2 Caracterização pedológica

7.1.3 Caracterização geotécnicas dos sedimentos ..............................127

7.1.4 Avaliação geotécnica da área de estudo .....................................128

7.2 Protocolo de Avaliação de Rápidos (EPA, 1981; adaptado de CALLIXTO et al., 2002; XAVIER \& TEIXEIRA, 2007) ..............................133

7.3 Análise morfométrica da área de estudo .......................................137

8. PROPOSTA DE SISTEMA DE AVALIAÇÃO DE EROSÃO FLUVIAL 140

8.1 Parâmetros Climáticos 144

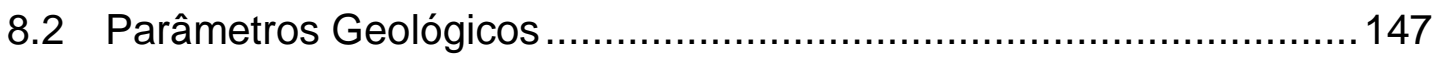

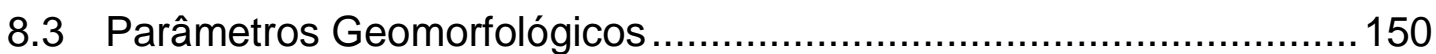

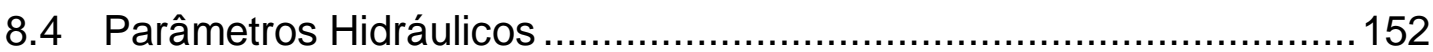

8.5 Parâmetros Pedológicos e Geotécnicos ...........................................156

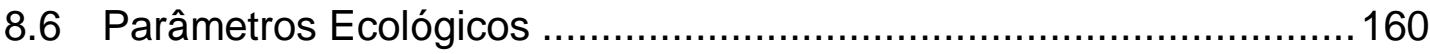

8.7 Parâmetros relacionados ao uso e ocupação do solo ........................162

9. APRESENTAÇÃO E ANÁLISE DOS RESULTADOS .......................174

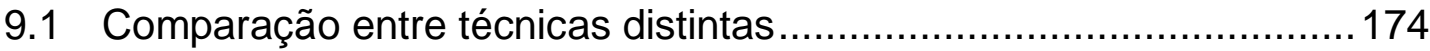

9.2 Análise dos dados do Sistema de Avaliação Geoambiental ...............178

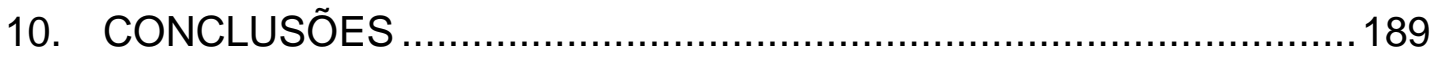

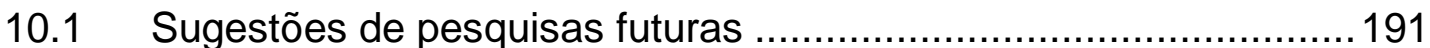

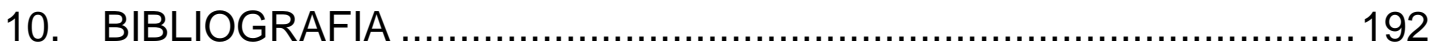

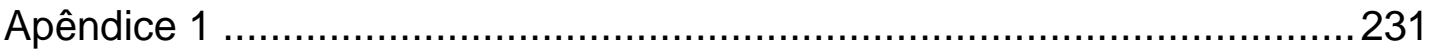

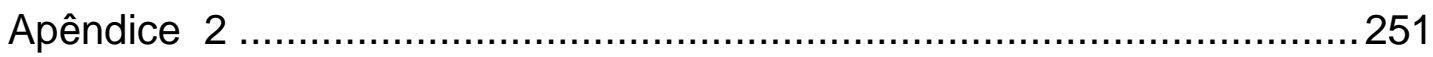

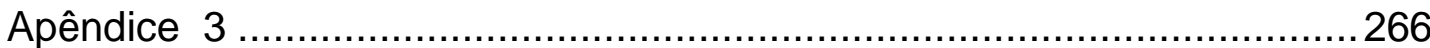

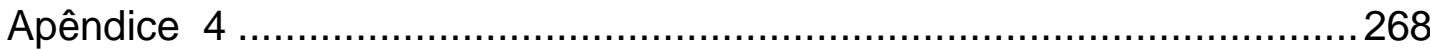


Apêndice 5

270 


\section{INTRODUÇÃO}

A água é um recurso mineral indispensável à manutenção da vida, sendo encontrada em diferentes ambientes/ ecossistemas.

Este patrimônio exerce um papel fundamental para todos os elementos do meio natural e do espaço construído.

No entanto, ela é utilizada, também, nos processos biológicos (alimento), como matéria-prima, na irrigação de vegetais úteis, como também, em aquavias, na geração de energia elétrica, na refrigeração de máquinas, nos processos químicos industriais e construtivos, na limpeza de ruas e no transporte de dejetos e resíduos em geral (BRANCO, 1991).

A água é um importante agente modelador do relevo, pois seu contato com as rochas causa alterações geoquímicas e geomecânicas, a ponto de transformar rochas em solos (residuais) ou erodir o manto de intemperismo, criando solos transportados e depósitos sedimentares inconsolidados ou mesmo erodindo os diferentes materiais geológicos encontrados próximos à superfície. Quando em circulação, mesma exerce um papel fundamental pois, além de distribuir os materiais geológicos de frações diferentes ao longo do terreno, propicia que a superfície evolua ao longo do tempo e do espaço.

Quando em escoamento, a água pode transportar estes materiais em suspensão, saltação e tração, dependendo do tamanho e densidades dos mesmos, ao longo do local onde a mesma se desloca, podendo gerar depósitos e estratificações geológicas, segundo a hidrodinâmica no interior do canal.

A água, quando encontrada em estado sólido, na forma de geleira, tem o poder de criar feições geomorfológicas, típicas de climas frios, como por exemplo, os vales fluviais em $\mathrm{U}$, estrias glaciais, depósitos de morenas, áreas formadas ao longo das geleiras que apresentam materiais geológicos de fração geralmente grosso, formados pela ação direta das geleiras, etc., devido ao peso do gelo em conjunto com os fragmentos de rochas transportados na parte frontal e lateral dessa massa congelada, promovendo a abrasão no substrato rochoso. 
Sob intervenção humana, o poder de alteração ambiental causado pela água é potencializado, pois ao entrar em contato com solos e rochas, em especial as de baixa competência, promove a erosão de suas margens, disponibilizando materiais geológicos que podem acelerar o processo natural de colmatação (assoreamento) dos corpos aquosos, comprometendo assim, todo o ecosistema fluvial.

Áreas ocupadas ao longo de rios, lagos e demais reservatórios, podem estar sujeitas a inundações, causando diversos problemas sócio-econômicos, inclusive, a proliferação de doenças, como a leptospirose, destruições de imóveis e infraestruturas de importante uso público, entre outros danos.Nos grandes centros urbanos, como na cidade de São Paulo (TUCCI, 1997) e Rio de Janeiro (CAMBRA \& COELHO NETO, 1997), essas áreas estão sujeitas aos problemas comentados anteriormente, gerando problemas sócio-econômicos e ambientais para a população e economia local.

Em áreas rurais, a modificação do uso do solo e alteração da faixa marginal têm acelerado o processo de erosão, criando feições erosivas do tipo ravina, voçoroca e erosão linear ao longo do seu leito maior e excepcional, podendo assorear os diferentes corpos aquosos.

Por tal importância que a água exerce na vida de toda uma sociedade, compreender sua dinâmica e interação, no caso, dos rios e córregos, com suas respectivas margens, sob o ponto de vista conservacionista, por exemplo, é de suma importância para se ter um ambiente mais harmônico entre homem e meio, via desenvolvimento sustentável.

Embora os rios sejam feições dinâmicas de curta duração, sob o ponto de vista geológico, tais elementos da paisagem estão sujeitos à interação entre as diferentes variáveis (volume de precipitação pluviométrica e velocidade dos ventos, condições geológico-geotécnicas de suas margens, flutuações climáticas; presença ou ausência de matas ciliares; vulcanismo e tectonismo, dentre outras questões), que dialogam entre si, com fluxos de matéria e energia diferenciados.

Por conta disto, avaliar as condições geoambientais destes ecossistemas e padronizar as variáveis relacionadas e correlacionadas ao processo de degradação dos rios é de suma importância, pois permite, além de comparar às condições do 
meio, ter seus dados utilizados no planejamento ambiental, em cursos d'águas localizados nas mais diversas áreas (rurais, urbanas, industriais, mistas e "naturais").

Do ponto de vista investigativo, estes ecossistemas são analisados sob diversas perspectivas, embora a maioria delas não seja adequada à compreensão processual da degradação ambiental, posto que põe em foco questões específicas, que as tornariam ineficazes na classificação do estado de conservação, não permitindo ou mesmo dificultando a comparação entre diferentes drenagens, pelo fato de que as variáveis envolvidas serem diversas.

O foco da maioria destas avaliações é variado, não considerando questões de natureza geomorfológica, geológico-geotécnica, bem como, hidrossedimentológica por exemplo, atores participantes do processo erosivo. Isso torna penosa a aplicação dos sistemas de avaliações vigentes, como testado por Albuquerque Sobrinho et al. (2010), no caso, o Protocolo de Avaliação de Rápidos (EPA, 1987). Faz-se, portanto, necessário uma abordagem multidisciplinar, envolvendo questões relacionadas às diferentes áreas do conhecimento, como climatologia, ecologia, hidráulica, pedologia, geologia, geomorfologia e geotecnia.

No outro extremo, a observação sobre a dinâmica da paisagem propiciou que muitos estudiosos criassem e utilizassem parâmetros morfométricos na classificação dos rios e das bacias hidrográficas (geomorfológica), tais como o hierarquização de drenagem (STRAHLER, 1952 apud COELHO NETTO \& AVELAR, 2002), os padrões das drenagens (LEOPOLD \& WOLMAN, 1957; SCHUMM, 1963; DURY, 1969; CHITALE, 1970 apud CHRISTOFOLETTI, 1981; CANT, 1982 apud NICHOLS, 1999), formato dos vales fluviais (THORNBURY, 1969) e pela disposição morfométrica (ROSGEN, 1994).

Sob o ponto de vista ecológico, a classificação dos rios é feita tanto na análise ambiental quanto no biomonitoramento, através do uso de comunidades biológicas, como por exemplo, animais bentônicos.

Isto se deve ao fato de que "as comunidades biológicas fornecem respostas integrais aos poluentes, e perturbação humana através da exposição contínua de magnitude, duração e frequência de estressores, constituindo-se assim como um importante avaliador da saúde ambiental" (BARBOUR \& PAUL, 2010). 
Existem diferentes sistemas de avaliação fluvial, voltado para abordagens diferentes (ecológica, ecotoxicológica e geomorfológica) como por exemplo o Protocolo de Avaliação de Rápidos (EPA, 1987), River Habitat Survey (BALESTRINI; CAZZOLA; BUFFAGNI, 2004), AQEM (HERING et al., 2004; BALESTRINI; CAZZOLA; BUFFAGNI, 2004). Urban River Survey (DAVENPORT; GURNELL; ARMITAGE, 2004), Water Framework Directive (BARBOUR \& PAUL, 2010), Índices de Avaliações Ambientais para Qualidade da Margem de Rio, composto pelos índices: Índice de Estado Selvagem, Índice faixa tampão e Índice de Paisagem Ambiental (BRAIONI et al., 1994 apud BRAIONI et al., 2001), etc.

Devido à importância que os rios exercem na vida de toda uma sociedade, avaliar os diferentes níveis de degradação a que os mesmos estão sujeitos, é crucial na elaboração de políticas públicas conservacionistas.

Visando preencher esta lacuna, esta tese tem como objetivo propor um Sistema de Avaliação Geoambiental voltado aos ambientes fluviais, levando em consideração as variáveis que compõem esta trama de cunho sócio-econômico e ambiental, a fim de retratar além das condições do meio físico, os agentes causadores dos diferentes fenômenos de degração destes ambientes, em uma perspectiva multidisciplinar e sistêmica.

O tema em questão surgiu em consequência da hipótese inicial da presente tese, onde ao analisar a área de estudo, por meio do mapa topográfico da região, percebeu-se que sua drenagem encontrava-se com alinhamento estrutural, dando como hipótese, a influência de feições morfotecctônicas.

No trabalho de campo inicial, não foi encontrado nenhum elemento geológico a fim de apoiar essa hipótese, embora as camadas geológicas estejam discordantes em relação à orientação da drenagem.

Com o desenvolvimento do tema da degradação do ambiente fluvial, percebeu-se uma certa variedade de técnicas usadas para o propósito inicial (avaliação da drenagem em questão), surgindo a ideia de propor uma ferramenta de avaliação da qualidade física dos cursos d'água, de modo que a mesma apontasse os atores causadores da degradação do córrego em foco.

Desta forma, nasceu esta proposta investigativa, de cunho quali-quantitativa, que aqui se apresenta. 
Para isto, a presente tese foi organizada da seguinte forma:

a) O capítulo 1 - Introdução do tema e sua importância;

b) O capítulo 2 - Apresentação dos objetivos da tese (geral e específicos);

c) O capítulo 3 - Exposição da justificativa de se propor este sistema de avaliação voltado aos ambientes fluviais;

d) O capítulo 4 - A revisão da literatura está inserida neste capítulo, onde os temas relacionados e correlacionados às abordagens fluviais foram revisados, bem como, as variáveis que compõem o corpo do sistema de avaliação em proposição foram expostos e justificados quanto aos pesos atribuídos as mesmas, seguido da técnica de mapeamento adotada, as propriedades morfológicas e físicas dos solos usadas na avaliação comparativa entre esta abordagem de cunho geológico-geotécnica e o sistema em questão; bem como a técnica de mapeamento geotécnico adotado no registro cartográfico dos dados obtidos;

e) O capítulo 5 - Caracterização fisiográfica da área de estudo, tanto em um contexto regional, quanto local, é abordada neste capítulo, incluindo ainda a localização espacial da área de estudo;

f) O capítulo 6 - Materiais e métodos adotados na elaboração deste trabalho são observados aqui, incluindo os procedimentos em campo, laboratório e em gabinete;

g) O capítulo 7 - A apresentação dos resultados obtidos por meio do sistema de avaliação em foco com Protocolo de Avaliação de Rápidos (EPA, 1987), é feita neste espaço, onde as bases conceituais que permeiam este capítulo foram explanados previamente, no capítulo 4;

h) O capítulo 8 - Dos dados apresentados no capítulo anterior incluindo o registro cartográfico destas informações serão analisados aqui;

i) O capítulo 9 - Apresentação das conclusões e considerações finais, bem como, propostas para pesquisas futuras;

j) O capítulo 10 trazas referências bibliográficas adotadas no escopo desta tese. 


\section{OBJETIVOS}

\section{Geral:}

- Propor um Sistema de Avaliação Geoambiental para cursos d'água localizados no interior do continente, de modo a servir como ferramenta de investigação e avaliação da qualidade física dos rios.

\section{Específicos:}

- $\quad$ Propor uma ferramenta para análise geoambiental aplicada a cursos d'águas continentais;

- Comparar os resultados obtidos pelo sistema em proposição, com o Protocolo de Avaliação de Rápidos (EPA, 1987), com a Análise Morfométrica (conjunto de parâmetros idealizados por diferentes autores), e com estudo geológico-geotécnico do Córrego das Cruzes;

- Avaliar a ferramenta de investigação geoambiental na análise do meio físico, e;

- Representar cartograficamente a condição ambiental da área de estudo por meio da técnica de Detalhamento Progressivo. 


\section{JUSTIFICATIVA}

As técnicas usadas nas investigações sobre a qualidade ambiental dos rios, inclusive sobre os processos erosivos que ocorrem ao longo deles, além de serem diversas, apresentam variações quanto aos parâmetros a serem adotados para tais fins, apresentando resultados divergentes, se comparados com a realidade local.

Integrar as múltiplas variáveis que atuam diretamente e indiretamente na definição da qualidade ambiental, contribuiria, amplamente, no aprimoramento das análises de caráter sistêmico, facilitando a abordagem ambiental e comparação entre rios, que ao final, serviria como ferramenta a ser empregada no planejamento ambiental.

Estes dados serviriam na tomada de decisão sobre o gerenciamento, que futuramente, facilitaria na escolha da(s) técnica(s) mais apropriada(s) para o controle do processo erosivo, embora não seja o foco deste trabalho, não impede que através da aplicação deste sistema de avaliação, o(s) agente(s) deflagador(es) do problema da erosão possa(m) ser sanado(s) ou minimizado(s), ao identificar os agentes causadores deste problema.

Por conta disso, propor um sistema que leve em conta o tipo climático, as formas de relevo existentes, a constituição geológica do local e suas características geotécnicas, incluindo, ainda, os tipos de uso do solo do entorno, etc., contribuiria para uma abordagem multidisciplinar, como também, auxiliaria na tomada de decisão, no gerenciamento e na escolha da(s) técnica(s) de controle de erosão mais adequado, embora tais questões não sejam o foco principal deste trabalho, não impedindo que através da aplicação deste sistema de avaliação, o(s) agente(s) deflagador(es) do problema de degradação ambiental, que inclui a erosão (canal e/ou margens), possam ser corrigidos ou minimizados.

O sistema aqui proposto visa ser uma ferramenta a ser utilizada no planejamento do uso do solo localizado ao longo das drenagens fluviais, tanto em áreas rurais, urbanizadas, mineradoras e industrializadas, já que os rios são agentes potencializadores da degradação ambiental, podendo ser intensificado pela ação antrópica indiscriminada, sob condições desfavoráveis do meio físico. 
O Córrego das Cruzes, local teste para o sistema de avaliação aqui proposto, é um curso de água de segunda ordem, cuja drenagem encontra-se em processo de degradação ambiental, posto que o mesmo apresenta diferentes problemas geotécnicos, como a erosão do solo formando feições erosivas do tipo laminar, ravina e voçoroca, assoreamento em parte do canal, dentre outros.

\subsection{Localização da Área de Estudo}

O Córrego das Cruzes está inserido na Unidade Hidrográfica de Gerenciamento de Recursos Hídricos 19, localizado a cerca de $30 \mathrm{~km}$ do município de Santo Antônio do Aracanguá, cujo acesso, partindo da cidade de São Carlo/SP, é feito pelas vias: Rodovia Washington Luiz (BR-463), Rodovia Feliciano Salles da Cunha (BR-262), Estrada Municipal Major Prado (SP-463), Rodovia Dr. Elyeser Montenegro Magalhães (SP-463) e Estrada Municipal Santo Antonio do Aracanguá (SP-463), como mostra a figura 1.

O referido município conta com uma micro-bacia composta pelos rios: Ribeirão das Cruzes, $478,72 \mathrm{~km}^{2}$, Ribeirão do Barreira, $327,80 \mathrm{~km}^{2}$, Ribeirão Lambarí, $420,2 \mathrm{~km}^{2}$, Córrego do Aracanguá, $315,44 \mathrm{~km}^{2}$, e Ribeirão Macaúbas, $779,25 \mathrm{~km}^{2}$ que fazem parte do Comitê da Bacia Hidrográfica do Baixo Tietê, 2009, - que se destina à UHE Três Irmãos (Rio Tietê). Vale salientar que o Córrego das Cruzes desagua em um ribeirão de mesmo nome.

A densidade populacional de Santo Antonio do Aracanguá é tida como inexpressiva $\left(5,14 \mathrm{hab} / \mathrm{km}^{2}\right)$ ao contrário de Araçatuba (30 $\mathrm{km}$ de distância) que corresponde a cidade de maior densidade populacional da UGRHI 19 (Comitê da Bacia Hidrográfica do Baixo Tietê, 2009). 


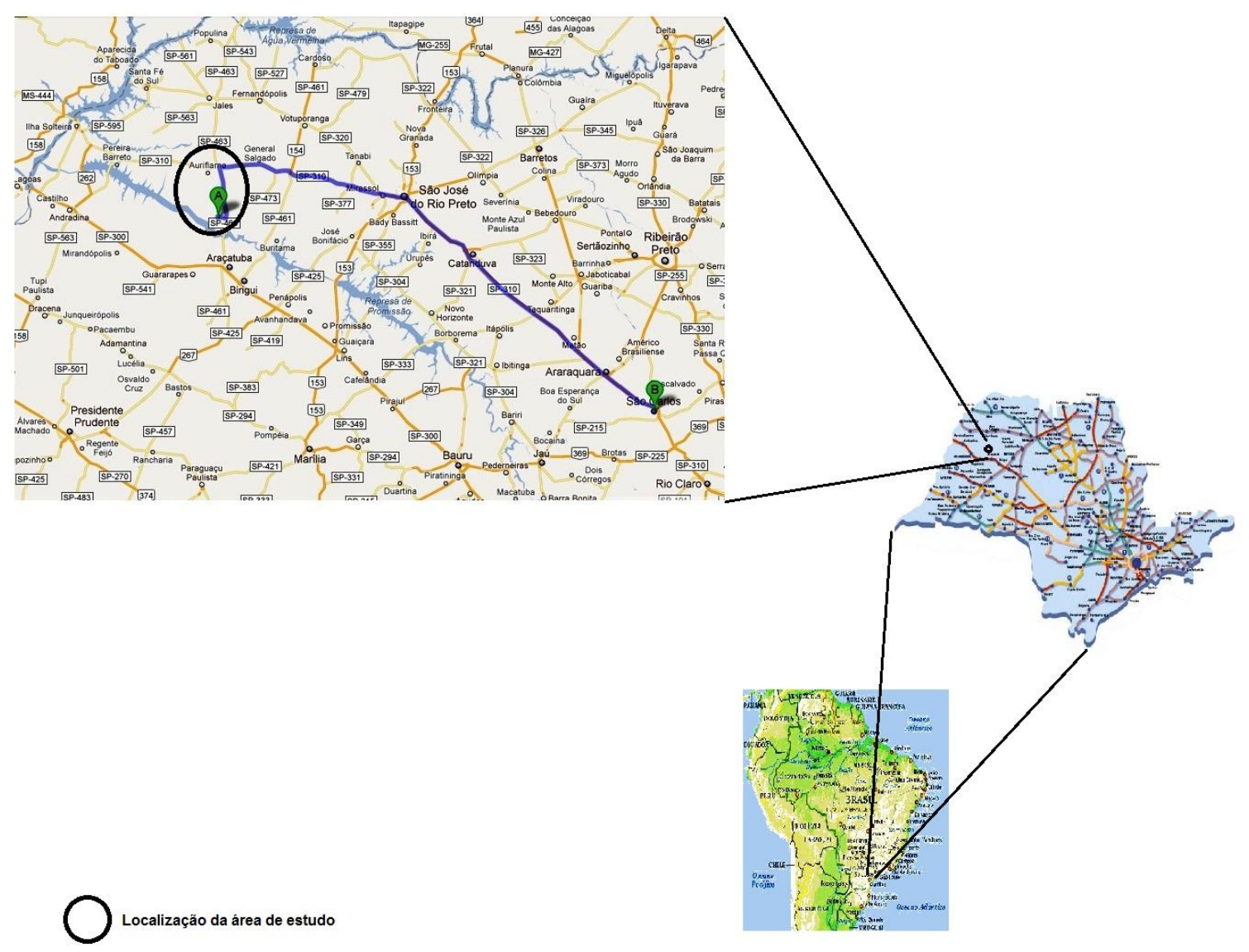

Figura 1 - Localização espacial da área de estudo (Fonte: Adaptado de Google, 2009 \& CBH-BT, 2009). 


\section{REVISÃO DE LITERATURA}

Neste capítulo é apresentado a revisão bibliográfica sobre os temas relacionados e correlacionados com a temática geral que compõe a tese, com ênfase nas variáveis que influenciam diretamente e indiretamente no processo de degradação fluvial, desde o próprio canal fluvial, como também, suas margens (leito menor ao excepcional).

Estas margens podem ocorrer em áreas de topografia aplainadas quanto íngrimes, dependendo da evolução geológica e geomorfológica dos locais onde os rios se apresentam.

Esta revisão bibliográfica e a própria tese foram direcionadas aos ambientes fluviais continentais, posto que os processos deflagradores da alteração física em ambientes estuarinos são diferentes dos que ocorrem no continente, posto que na zona costeira, incluindo os estuários, apresentam fluxo de matéria e energia distintos, como citado por Meireles \& Campos (2010): deriva litorânea, fluxo eólico, fluviomarinho, hidrogeológico, fluvial/pluvial, lacustre, lagunar e gravitacional. Poderse-ia incluir, ainda, a interação entre estes fluxos com infra-estruturas construidas (portos on shore e off shore e demais construções civis, instalação de infraestruturas de contenção à erosão costeira), cujo contato poderia contribuir na degradadação geoambiental.

A dinâmica do processo erosivo não respeita as barreiras físicas naturais e artificiais, ao passo que integrar os fenômenos e variáveis realizadas que participam deste processo, não é uma das tarefas mais fáceis, pois as questões comumente observadas durante a degradação do meio físico dos ambientes fluviais foram levadas em consideração, para ser uma ferramenta tecnicamente mais acessível a grande maioria dos profissionais em geociências, bem como sua aplicação para fins didáticos (avaliação ambiental).

NO sistema aqui proposto, por haver muitos parâmetros de outras áreas do conhecimento, requerendo pessoas com bases conceituais mais generalistas (holístico) de outras áreas do saber, como geógrafos, geológos, biólogos e engenheiros ambientais, ou mesmo a integração de profissionais de áreas distintas 
para aplicação deste sistema, que coleta parte dos dados em campo e os processa em laboratório.

\section{1 Abordagens utilizadas em estudos de erosão e suas múltiplas escalas}

Os corpos hídricos (rios e bacias hidrográficas), enquanto objetos de estudos, são analisados sob diferentes técnicas e escalas de observação.

A análise da vulnerabilidade à erosão dos rios e bacias, como também, a definição destes espaços pode ser realizada por meio de técnicas distintas.

As principais abordagens utilizadas em estudos sobre erosão em rios, tanto no Brasil quanto no exterior, podem ser observadas na tabela 1, onde alguns dos trabalhos produzidos são exemplificados, inclui-se, também definições a respeito do o curso d'água e localidade da mesmo.

Ao se observar a tabela 1, pode-se perceber como as técnicas de obtenção de dados espaciais vêm se aprimorando.Desde década de 80 do século passado, o uso de sensores remotos por fotografia aérea contribuíram para os estudos ambientais; nos dias atuais, também pode-se constatar o uso de outros sensores de forma popularizada, como por exemplo, uso de imagens de satélites e a fixação de Escâner a Laser em aeronave permitiu o aprimoramento das técnicas de coleta de dados, sob diferentes escalas de observação.

Vale salientar que, em função das características da área de estudo, optou-se em elaborar o mapa básico, bem como, os temáticos a partir de informações oriundas de levantamentos topográfico e batimétrico por Estação Total, já que o córrego em questão além de ser estreito e raso, o Núcleo de Hidrometria do PPGSEA possui este equipamento para tal finalidade.

Neste quesito, os equipamentos usados foram: estação total (margens e canal na porção mais rasa) e ecobatimetria (contato entre o Córrego das Cruzes e Ribeirão das Cruzes).

Os dados relacionados aos equipamentos e aos procedimentos utilizados durante a realização da coleta de campo encontram-se em Materiais e Métodos (ver capítulo 6). 
A tabela 1 exemplifica os diferentes trabalhos relacionados ao ambiente fluvial, onde se pode constatar a diversidade de técnicas que podem ser utilizadas para fins distintos, embora TODAS elas passíveis de serem aplicadas ao estudo da qualidade física de rio, foco principal desta tese.

Tabela 1 - Exemplos das diferentes abordagens adotadas no estudo do problema da erosão em ambientes fluviais comumentes adotados.

\begin{tabular}{|c|c|c|}
\hline Técnica & Local & Autor \\
\hline Cartografia por aerofotogrametria & $\begin{array}{l}\text { Bacia Wollongong, Illawarra - } \\
\text { Austrália }\end{array}$ & $\begin{array}{lll}\text { NANSON } & \& & \text { YOUNG } \\
(1981) & & \end{array}$ \\
\hline $\begin{array}{lll}\text { Cartografia, } & \text { Topografia } & \mathrm{e} \\
\text { batimetria } & & \end{array}$ & Rio Paraná, Porto Rico - PR & $\begin{array}{l}\text { SANTOS; FERNANDEZ; } \\
\text { STEVAUX (1992) }\end{array}$ \\
\hline $\begin{array}{l}\text { Simulação computacional (SWAT, } \\
\text { Simulação computacional) }\end{array}$ & $\begin{array}{l}\text { Ribeirão do Marins, Piracicaba - } \\
\text { SP }\end{array}$ & MACHADO (2002) \\
\hline Análise morfométrica e cartografia & $\begin{array}{l}\text { bacia hidrográfica do Rio Mogi } \\
\text { Guaçu, região Centro-Oriental }\end{array}$ & ZANCOPÉ (2004) \\
\hline $\begin{array}{l}\text { Simulação } \\
\text { (EUPS/SWAT } \\
\text { geoprocessamento) }\end{array}$ & $\begin{array}{l}\text { Ribeirão do Feijão, São Carlos - } \\
\text { SP }\end{array}$ & MINOTI (2006) \\
\hline $\begin{array}{l}\text { Simulação computacional (RUSLE } \\
+ \text { geoprocessamento) }\end{array}$ & $\begin{array}{l}\text { Bacia de Ribagorzana, Huesca - } \\
\text { Espanha }\end{array}$ & $\begin{array}{ll}\text { VICENTE; } & \text { NAVAS; } \\
\text { MACHÍN (2009) } & \end{array}$ \\
\hline Scanner laser terrestre (LiDAR) & $\begin{array}{l}\text { Glaciares Mont Miné e Ferpècle, } \\
\text { Valais - Suiça }\end{array}$ & MILAN et al. (2007) \\
\hline $\begin{array}{l}\text { GPS e Protocolo de Avaliação } \\
\text { Rápida de Diversidade de Habitats }\end{array}$ & Rio São João, Itaúna - MG & $\begin{array}{l}\text { XAVIER \& } \\
(2007)\end{array}$ \\
\hline $\begin{array}{lr}\begin{array}{l}\text { Zoneamento } \\
\text { geoprocessamento, }\end{array} & \text { ensiental, } \\
\text { geotécnicos, } & \text { cartografia } \\
\text { geotécnica } & \end{array}$ & $\begin{array}{l}\text { Rios Jacupiranga e Pariquepra- } \\
\text { açú, Vale do Ribeira - SP }\end{array}$ & LOURES (2008) \\
\hline Ground Penetration Radar (GPR) & $\begin{array}{ll}\text { Rio Taquari, } & \text { Pantanal } \\
\text { Matogrossense } & \end{array}$ & $\begin{array}{l}\text { MOUTINHO; PORSANI; } \\
\text { PORSANI (2005) }\end{array}$ \\
\hline $\begin{array}{l}\text { Simulador de } \\
\text { geoprocessamento e } \\
\text { laboratoriais }\end{array}$ & $\begin{array}{l}\text { Microbacia do Rio Caiabi (Bacia } \\
\text { Amazônica), MT }\end{array}$ & $\begin{array}{l}\text { FRANCESCHET et al. } \\
(2010)\end{array}$ \\
\hline
\end{tabular}




\section{2 Variáveis que influenciam na degradação dos rios e de seu entorno}

De acordo com Christofoletti (1980), a erosão fluvial ocorre através de três processos distintos: a corrosão (engloba todo e qualquer processo químico que se realize, como reação entre a água e as rochas superfícies que estão em contato com a água); corrasão (desgaste mecânico causado pelo atrito das partículas carregadas pela água, onde tais materiais causam a abrasão do leito, promovendo o polimento do substrato rochoso) e a cavitação (ocorre pelas variações de pressões sobre as paredes do canal, facilitando a fragmentação de suas rochas, devido às condições elevadas de velocidades da água).

Contudo, a erosão pode ocorrer tanto no interior dos rios quanto nas bacias hidrográficas, ocorrendo em diferentes porções não só no interior da própria drenagem como também, em suas margens, podendo seu processo erosivo ocorrer de forma mista, ao longo da mesma.

A capacidade de erosão do terreno, no caso, o espaço entre o talvegue e o leito excepcional, dependendo das diferentes variáveis, como o clima, formas de relevo, as condições geológico-geotécnicas de solos e rochas, condicionantes hidrodinâmicos do rio, aspectos vegetacionais do entorno (higrófilas, higrófitas e matas ciliares), bem como, uso e ocupação da bacia e da drenagem, pois dependendo do tipo de utilização, o impacto nas margens e no interior do rio pode ser mais proeminente, gerando, dentre outras coisas, erosão e deposição de materiais geológicos, na forma de assoreamento.

A capacidade dos rios serem degradados, no caso, o espaço geomorfológico entre o talvegue e o leito excepcional, dependendo ainda de diferentes variáveis, como o clima, formas de relevo, as condições geológico-geotécnicas de solos e rochas, condicionantes hidrodinâmicos do rio, tipo de vegetação do entorno (higrófilas, higrófitas e matas ciliares), as formas de uso e ocupação da bacia e da drenagem, elaborando feições erosivas nas margens e assoreamento do canal.

Vale ressaltar que, na natureza, os elementos da paisagem tais como clima, solo, vegetação, entre outros, interagem entre si, dificultando uma análise detalhada do papel de cada elemento, atuando no processo de degradação ambiental, tanto 
facilitando o processo quanto amenizando-o, em uma distribuição de forças (açãoreação).

Lal (1990) apud de Lima, (2003) agrupou as diferentes variáveis através das características físicas, químicas, mineralógicas e biológicas dos solos que proporcionam diferentes comportamentos durante o processo erosivo (ver tabela 2).

$\mathrm{Na}$ tabela 2, estes fatores que influenciam no problema da erosão foram compartimentados em: propriedades, fatores, e características físicas, químicas e biológicas.

Tabela 2 - Fatores que influem na suscetibilidade à erosão dos solos (adaptado de LAL, 1990 apud de LIMA, 2003).

\begin{tabular}{|c|c|c|}
\hline \multicolumn{3}{|c|}{ FATORES QUE INFLUEM NA SUSCETIBILIDADE Ȧ EROSÃO DOS SOLOS } \\
\hline PROPRIEDADES & FATORES & CARACTERISTICAS \\
\hline \multirow{4}{*}{ Mecânicas } & Textura & $\begin{array}{l}\text { Influi no destacamento e carreamento de partículas do } \\
\text { solo. } \\
\text { Determina a facilidade com que o solo se dispersa. }\end{array}$ \\
\hline & Estrutura & $\begin{array}{l}\text { Formação de agregados que resistem à dispersão, aos } \\
\text { efeitos abrasivos da água de escoamento e ao } \\
\text { destacamento. } \\
\text { Grau de agregação e distribuição de agregados estáveis. }\end{array}$ \\
\hline & $\begin{array}{c}\text { Tamanho dos torrões e } \\
\text { cultivos do solo }\end{array}$ & $\begin{array}{l}\text { Resistência à desagregação pela chuva e erosão pelo } \\
\text { vento. }\end{array}$ \\
\hline & Formação de crosta & $\begin{array}{l}\text { Responsável pela alta taxa de escoamento superficial. } \\
\text { Desenvolve-se em solos com baixa porcentagem de } \\
\text { matéria orgânica. }\end{array}$ \\
\hline \multirow[t]{2}{*}{ Resistência } & $\begin{array}{l}\text { Resistência ao } \\
\text { cisalhamento }\end{array}$ & $\begin{array}{l}\text { Rolamento e deslizamento de grãos. } \\
\text { Importante no destacamento de partículas de solo } \\
\text { (impacto e escoamento superficial). }\end{array}$ \\
\hline & Retenção de água & $\begin{array}{l}\text { O estado de energia da água do solo ou pressão neutra } \\
\text { influencia a resistência ao cisalhamento do solo. } \\
\text { Resistência do solo ao arrastamento pela água é } \\
\text { influenciada pela umidade inicial ou antecedente. } \\
\text { Solos secos são mais susceptíveis à erosão pelo vento e } \\
\text { pela água do que solos úmidos. }\end{array}$ \\
\hline
\end{tabular}




\begin{tabular}{|c|c|c|c|} 
Hidrológicas & $\begin{array}{c}\text { Transmissão de } \\
\text { água no solo- } \\
\text { infiltração }\end{array}$ & $\begin{array}{c}\text { Taxa de infiltração determina o maior ou menor volume } \\
\text { de escoamento superficial. }\end{array}$ \\
\cline { 2 - 4 } & Permeabilidade & $\begin{array}{c}\text { Solos com permeabilidade extremamente baixa a } \\
\text { moderada geram mais escoamento superficial. }\end{array}$ \\
\hline Reológicas & Sistema solo/água & $\begin{array}{c}\text { Umidade do solo influi na suscetibilidade à erosão por } \\
\text { afetar a coesão, a resistência ao cisalhamento, consistência e } \\
\text { plasticidade. }\end{array}$ \\
\hline
\end{tabular}

Continuação da tabela 2.

\begin{tabular}{|c|c|c|}
\hline \multicolumn{3}{|c|}{ FATORES QUE INFLUEM NA SUSCETIBILIDADE Ȧ EROSÃO DOS SOLOS } \\
\hline PROPRIEDADES & FATORES & CARACTERISTICAS \\
\hline $\begin{array}{l}\text { Químicas e } \\
\text { mineralógicas }\end{array}$ & Matéria orgânica & $\begin{array}{l}\text { Influencia a distribuição granulométrica, propriedades de } \\
\text { retenção e transmissão de água. } \\
\text { Fortalece as ligações que estabilizam as unidades } \\
\text { estruturais e mantém um balanço favorável entre retenção e } \\
\text { transmissão nos poros. } \\
\text { Diminui o efeito de compactação. } \\
\text { Concentração de matéria orgânica nos micro-agregados } \\
\text { aumenta a sua resistência à desagregação ("Slacking") e à } \\
\text { dispersão. } \\
\text { Elevadas concentrações de M.O. em alguns solos são } \\
\text { responsáveis pelas características hidrofóbicas. }\end{array}$ \\
\hline \multirow{2}{*}{$\begin{array}{c}\text { Características do } \\
\text { perfil }\end{array}$} & Argilo-minerais & $\begin{array}{l}\text { Estrutura do solo e a sua resistência são influenciadas } \\
\text { pela quantidade e natureza dos argilo-minerais. } \\
\text { Fração fina do solo interage com a matéria orgânica para } \\
\text { formar agregados estáveis que resistem ao impacto das } \\
\text { gotas da chuva. }\end{array}$ \\
\hline & Diretos e indiretos & $\begin{array}{l}\text { Influencia a erosão direta e indiretamente. } \\
\text { Influência sobre o escoamento subsuperficial de água } \\
\text { em decorrência de mudanças nas propriedades hidrológicas } \\
\text { de diferentes horizontes. } \\
\text { Influência sobre o crescimento vegetal. }\end{array}$ \\
\hline
\end{tabular}

Parte destas variáveis faz parte do sistema de avaliação desta tese, cujos parâmetros e pesos foram atribuídos na participação destes na degradação dos rios e de suas margens, como pode ser observado no capítulo 7 . 
Embora esta tese esteja relacionada com as condições geoambientais dos corpos fluviais, incluindo o processo erosivo que pode ocorrer no interior dos canais naturais, os solos localizados nas margens dos corpos d'água exercem um papel importante no processo erosivo das drenagens, já que este problema geotécnico afeta, além do próprio canal (leito menor) até à área correspondente ao leito excepcional, cuja observação do limite físico da drenagem é observada nas enchentes que ocorrem em longos intervalos de tempo (anos e/ou décadas).

A seguir é apresentado o arcabouço teórico dos elementos que compõem o sistema de avaliação de erosão em rios, iniciando-se pelas abordagens feitas neste tipo de estudo, suas múltiplas escalas de análise e seus aspéctos técnoinstrumental.

\subsubsection{O clima como agente modelador do terreno}

O clima exerce um papel fundamental, não só na produção de alimentos (DANTAS; CARVALHO; FERREIRA, 2007), como também, como um importante agente modelador da superfície do planeta.

De modo geral, sua ação dá-se pela interação entre os elementos do clima (temperatura, umidade, ação do vento, crioclastia e pelo volume de precipitação pluviométrica) com a superfície do terreno (tanto em solo quanto em rocha).

O volume de precipitação pluviométrica e sua distribuição espacial têm um papel importante na dinâmica ambiental, embora seus efeitos possam ser drásticos quando associado aos tipos de uso do solo, cujos efeitos transcendem aos impactos sócio-econômicos e ambientais associados, como citado por Menescal; Figueiredo; Franco (2005), para a cidade de Fortaleza (capital do Ceará, nordeste do Brasil).

Uma de suas características, enquanto agente modelador do terreno, é o de retrabalhar os materiais geológicos que compõem o substrato (terroso e rochoso), pois em regiões de clima semi-árido, por exemplo, o escoamento superficial e produção de sedimentos gerados têm um papel importante, já que a constituição vegetal predominante xerófita não permite grande proteção ao impacto das gotas de chuva sobre o solo (efeito "splash"), e em conjunto com práticas predatórias, como 
as queimadas, os sedimentos produzidos são carreados em direção aos rios e demais reservatórios, causando o assoreamento e perda da capacidade de acumulação de água, prejudicando o abastecimento das comunidades (SANTOS, 2009).

Nestes locais, onde predomina a ação física do clima sobre o meio, cujo volume e a distribuição das chuvas são irregulares, este processo ocorre de forma diferente ao longo do processo pedogenético, fazendo com que os solos sejam rasos, tendendo a pedregosos, cuja vegetação xerófita é adaptada ao regime climático.

"Sob a atuação de climas regidos por temperaturas relativamente elevadas e períodos destacados de déficit e excedente pluviométrico, as superfícies aplainadas dos continentes são submetidas à ação do intemperismo químico que constrói e reconstrói suas formas, juntamente com as estruturas das rochas que as compõem. Ao contrário dos processos mecânicos de transformação do relevo, a formação e o equilíbrio das formas concrecionárias e/ou lateríticas é algo que se desenvolve lentamente, envolvendo longos períodos de tempo" (CABRAL \& PRADO, 2008).

Os componentes que atuam na caracterização climática de uma determinada região estão associados à dinâmica atmosférica, que atuam nos diferentes sistemas atmosféricos (ZCAS, ZCIT, massas polares, equatoriais, etc.) atribuindo-lhe particularidades regionais, associadas à localização geográfica (altitude, maritimidade e continentalidade), etc.

Através da gama de variáveis que compõe o clima, diferentes classificações climáticas foram criadas, incluindo as de Köppen (1928) e Thornthwaite (1948).

Neste trabalho adotou-se a de Köppen por ser uma das mais difundidas, e de fácil utilização.

Nesta classificação, Köppen identificou as regiões climáticas da terra, por meio da vegetação, associando valores numéricos referentes à temperatura e volume de precipitação pluviométrica e neste sentido, segmentou-se 5 zonas fundamentais de clima, separando as variedades específicas de precipitação e temperatura (OMETTO, 1981).

Köppen \& Geiger (1928) e Ometto (1981), Köppen compartimentou em duas zonas distintas, onde uma era de climas úmidos (A - Tropical chuvoso, C - 
Temperado chuvoso e, D - Clima boreal/ Bosque nevado) e outra de climas secos (zona de clima B - Climas secos), que por outro lado, foram subdivididas de acordo com o valor apresentado nos 4 meses, cuja temperatura foi maior ou menor que $10^{\circ} \mathrm{C}$ : a - Subtropical $\left(>22^{\circ} \mathrm{C}\right), \mathrm{b}-$ Temperado $\left(<22^{\circ} \mathrm{C}\right)$, ou mesmo maior ou menor que $38^{\circ} \mathrm{C}, \mathrm{c}-$ Frio $\left(>38^{\circ} \mathrm{C}\right)$, e, $\mathrm{d}-$ Muito frio $\left(<38^{\circ} \mathrm{C}\right)$.

Quanto ao papel exercido pelo clima nas atividades agrícolas, Dantas, Carvalho e Ferreira (2007) afirmam que a precipitação pluviométrica corresponde a um dos elementos climáticos que pode apresentar grande variabilidade. Neste caso, o excesso ou falta de água afeta o sistema solo-planta atmosfera e reduz a produtividade agrícola., os autores não aconselham seu uso em estudos agroclimáticos regionais como na determinação de zonas agrometeorológicas, que não é o caso desta tese.

A precipitação pluviométrica é sem dúvida um dos maiores agentes causadores da erosão, pois sua ação se dá pela água da chuva em que as forças devidas ao escoamento superficial e subsuperficial que se instalam em função de um episódio de precipitação são capazes de proceder ao arranque e arraste das partículas do solo (SCHMIDT, 1991; GONÇALVES, 2002; VALDIVIESO, 2004; ZUQUETTE; CARVALHO; YAMANOUTH, 2007).

Em regiões de clima árido e semi-árido, o vento constitui como um importante agente erosivo, transportando o material geológico particulado, pela movimentação e circulação do ar (ZACHAR, 1982), embora tal fenômeno não tenha sido observado na área de estudo, o mesmo não foi incluído neste sistema de avaliação, por ser um fenômeno que ocorre, principalmente, em áreas em costeiras e desérticas, cujo aporte de sedimento e a velocidade dos ventos são o suficiente enérgicas para transportar estes produtos particulados, ao longo de uma determinada área.

Por outro lado, estes locais com baixo volume anual de chuva também estão sujeitos às precipitações extremas, onde chuvas de grande volume e pouca duração têm um enorme poder de erodir os solos e causar o assoreamento dos cursos de água.

A região da área de estudo se enquadra na faixa climática, segundo Köppen (1966) Aw, como pode ser observado na figura 2. 
Através da figura 3, observa-se a predominância do tipo climático Aw (Tropical chuvoso com inverno seco) e do tipo Af (clima tropical úmido ou superúmido, sem estação seca, onde a temperatura média do mês mais quente é superior a $18^{\circ} \mathrm{C}$ ) para o Estado de São Paulo, conforme mostrado por Rolim et al. (2007).

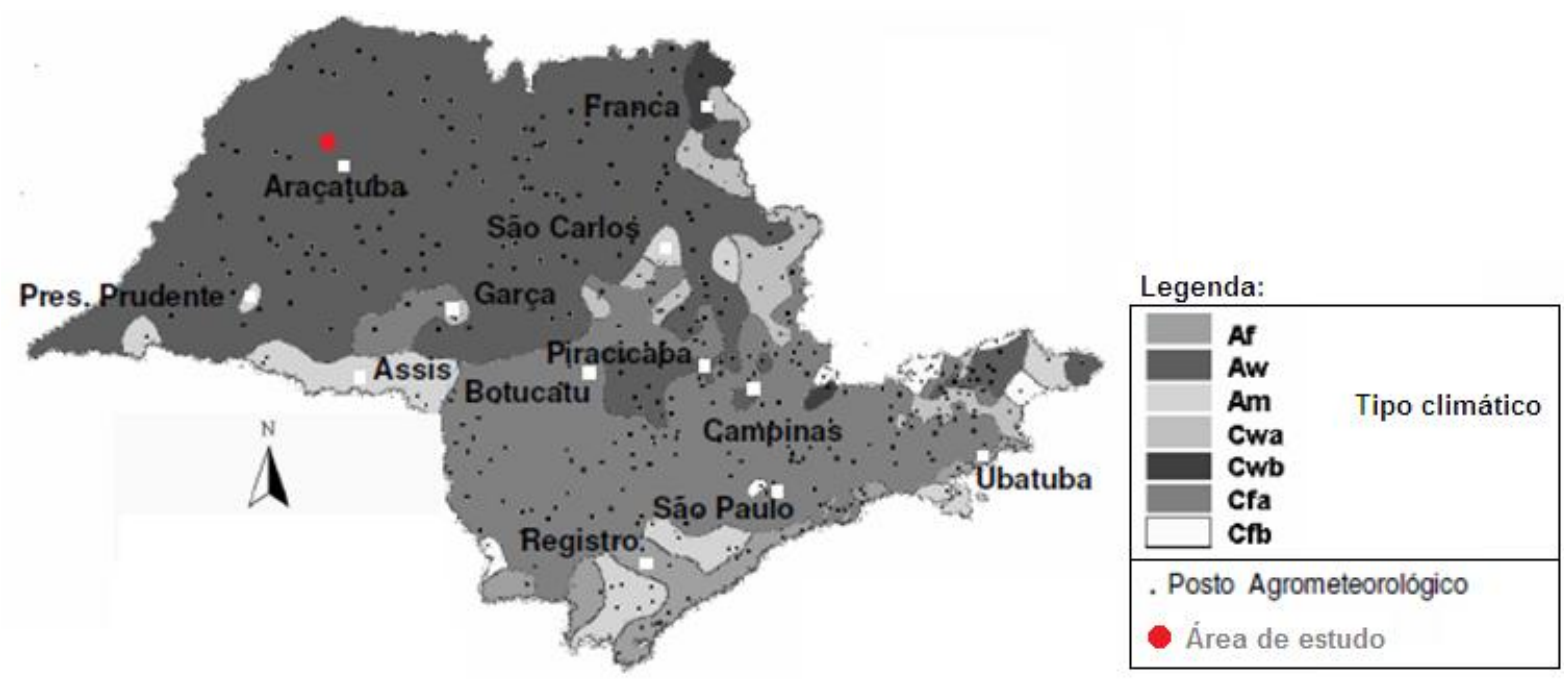

Figura 2 - Distribuição climática do Estado de São Paulo pelo sistema de Köppen (adaptado de SETZER, 1966 apud ROLIM et al. 2007).

Botelho \& Guerra (2003) elaboraram um estudo sobre a erosão dos solos, onde estes autores relacionaram o volume de precipitação de distintas áreas climáticas brasileiras em condições críticas de erosão, onde percebeu-se que o problema da erosão e consequentemente a degradação dos cursos de água, ocorrem sob diferentes condições climáticas e de meio físico distintas, sendo que em alguns casos, o uso inadequado dos solos com alta susceptibilidade à erosão foi potencializado pelo uso social, como pode ser vista através da tabela 3 .

A tabela 3 expressa os problemas sócio-ambientais que ocorrem nas diferentes zona climáticas do Brasil, embora certos problemas sejam comuns em diferentes áreas, como no caso do assoreamento dos corpos d'água.

Contudo, Schmidt (1991) comenta que, quando a intensidade da chuva é constante, o impacto causado pelas precipitações pluviométricas diminuem com o aumento do "run off" e aumento da profundidade do fluxo.

Geograficamente, as características físicas da chuva variam ao longo do território brasileiro, como apresentado por Crepani et al., (2001) apud Crepani; Medeiros; Palmeira (2004). 
Nas áreas urbanizadas, as precipitações pluviométricas de grande intensidade podem transportar os detritos provenientes do transporte feito pela água, durante o período de inundação, podem gerar assoreamento de parte da drenagem, alteração física de suas margens, erosão marginal e demais feições geomorfológicas existentes (WOLMAN, 1967).

Tabela 3 - Processos erosivos e seus impactos ambientais em áreas críticas brasileiras (Adaptado de BOTELHO \& GUERRA, 2003).

\begin{tabular}{|c|c|c|}
\hline Áreas críticas & $\begin{array}{l}\text { Precipitação } \\
\text { pluviométrica } \\
(\mathrm{mm})\end{array}$ & Problemas de erosão \\
\hline $\begin{array}{l}\text { Noroeste do } \\
\text { Paraná }\end{array}$ & $1.100-1.600$ & $\begin{array}{l}\text { Acelerados pelo ocucação territorial e formação de áreas } \\
\text { urbanas; atividades agrícolas e aspéctos geotécnicos } \\
\text { desfavoráveis }\end{array}$ \\
\hline Planalto central & 1.500 & $\begin{array}{l}\text { Processo de ocupação desordenado do campo e alta } \\
\text { mecanização das atividades no campo, causando } \\
\text { compactação dos solos, ocorrencia de erosão nos solos. }\end{array}$ \\
\hline Oeste paulista & 1.254 & $\begin{array}{l}\text { Área territorial com maior ocorrência de problemas } \\
\text { erosivos, solos geralmene arenosos, iversão de usos do } \\
\text { solo (urbano x rural), assoreamento de fundo de vales e } \\
\text { rios, }\end{array}$ \\
\hline $\begin{array}{l}\text { Médio vale do } \\
\text { Paraíba do Sul }\end{array}$ & 1.250 & $\begin{array}{l}\text { Área formada por relevos do tipo mares de morros, com } \\
\text { estação seca bem marcada ( } 4 \text { a } 5 \text { meses), forte incidência } \\
\text { de erosão malinar e linear, assoreamento de diferentes } \\
\text { reservatórios e derrubada de florestas nativas. }\end{array}$ \\
\hline $\begin{array}{l}\text { Campanha } \\
\text { Gaúcha }\end{array}$ & 1.400 & $\begin{array}{l}\text { Área em processo de desertificação por conta dos intensos } \\
\text { processos erosivos, os solos apresentam textura arenosa, } \\
\text { formação de ravinas e voçorocas nos interflúvios e meia } \\
\text { encosta, poca cobertura vegetal e aceleração do } \\
\text { escoamento superficial. }\end{array}$ \\
\hline Trângulo Mineiro & $\begin{array}{l}\text { Semi-úmido e } \\
\text { tropical úmido }\end{array}$ & $\begin{array}{l}\text { Importante região agropecuária do Estado de Minas Gerais } \\
\text { apresenta climas distintos, declividades do tereno variando } \\
\text { entre } 25^{\circ} \text { e } 40^{\circ} \text { onde afloram o basalto e de } 2^{\circ} \text { a } 5^{\circ} \text { em área } \\
\text { de relevo de topos aplainados e largos. }\end{array}$ \\
\hline
\end{tabular}


Desta forma, os parâmetros referentes ao clima, baseados na classificação de Köppen \& Geiger (1928) foram copilados e seus respectivos pesos foram atribuídos, como se observa nas tabelas 4,5 e 6 esta variável foi subdividida em três tabelas distintas em função da forma que a mesma foi proposta por KÖPPEN \& GEIGER (1928).

\subsubsection{Condicionantes geológicos indutores da erosão}

O processo de desgaste dos diferentes substratos geológicos (rochas, solos e depósitos sedimentares) ocorre segundo a dinâmica ambiental do local e da formação que os elabora.

As rochas são classificadas em três grandes grupos, baseados nos processos de formação das mesmas (ígneas, metamórficas e sedimentares).

Com relação à susceptibilidade ruptura de taludes rochosos, bem como a elaboração de feições erosivas nas porções compostas por solos residuais, Silva, Schulz e Camargo (2003) comentam que dentro do mesmo grupo litológico pode haver diferença na resistência contra este processo (desagregação física ou decomposição química), mas em diferentes locais e situações.

Este desgaste caracteriza-se por fissuras no terreno, materializadas na forma de erosão; embora nos cursos d'água, este problema geotécnico ocorra tanto no interior da drenagem quanto em sua área de influência, normalmente correspondendo à planície fluvial.

Zancopé (2004) cita a distribuição dos afloramentos rochosos das estruturas geológicas que influenciam na distribuição granulométrica dos materiais transportados pelo rio, incluindo ainda a mineralogia da carga detrítica e sua distribuição no perfil longitudinal; alinhamento da direção preferencial do curso d'água; erosão diferencial do fundo do leito e consequente efeito sobre o entalhamento do vale; e gradiente do curso d'água; entre outros.

Sob o ponto de vista da geomecânica, a variação da resistência das rochas depende dos seguintes fatores: tempo necessário para criá-las, conteúdo 
mineralógico, tempo de exposição aos agentes climáticos, tipo de clima, tensões exercidas sobre elas, etc.

Quando a modificação de um determinado seguimento de um rio, sobre rochas, o nível de degradação é bem diferenciado, quanto aos processos que ocorrem nos solos (residual ou transportado).

Rochas de mesmo conteúdo mineralógico podem apresentar textura e tamanho dos grãos diferentes, como no caso das rochas graníticas estudadas por Sousa (2004).

Por conta da variação dos tipos de rochas dentro do mesmo grupo litológico, optou-se em pontuá-los por grupo litológico que se encontram, como pode ser observado na tabela 8.

O processo de desprendimento e arraste acelerado das partículas do solo pode ser feito pela água e pelo vento. O mecanismo que gera este problema começa quando as gotas da chuva embatem a superfície do solo e destroem os agregados, culminando em: (a) desprendimento das partículas de solo; transporte do material desprendido, e em seguida, depósito em outros lugares(BERTONI \& LOMBARDE NETO, 1999).

Esta palavra, cuja origem é latina (BASTOS; MILITITSKY; \& GEHLING, 2000, erosão derivada do verbo erodere (corroer), podendo ser definida como sendo um conjunto de processos pelos quais os materiais da crosta terrestre são degradados, dissolvidos ou desgastados e transportados de um ponto a outro pelos agentes erosivos, tais como as geleiras, os rios, os mares, o vento ou a chuva (VILAR, 1987; PRANDI \& VILAR, 1993), como também, eventos de precipitações pluviométricas torrenciais podem causar danos sócio-econômicos e ambientais (DIODATO, 2005).

Neste caso, a influência das atividades humanas é apresentada no tópico 4.2.6, referente aos diferentes usos e ocupações.

Diferentes tipos de rochas sofrem o ataque dos agentes atmosféricos de formas distintas, embora, em sua grande maioria, seguem padrões distintos, como no caso do comportamento geotécnico do contato entre as rochas do tipo granítico e diabásica das encostas de Florianópolis (SC).

Os solos aluviais são encontrados no interior dos depósitos formados pelo transporte hidrodinâmico dos rios, podendo ser formados por aluviões antigos e 
recentes, na forma de faixas estreitas e alongadas com baixas alturas, correspondentes às planícies aluviais e terraços fluviais, encontrados ao longo das calhas dos rios principais (COSTA, 2009). Os mesmos são constituídos de materiais erodidos, retrabalhados e transportados pelos cursos d'água e depositados nos leitos ou margens dos mesmos (MEDRADO, 2009).

Estes solos possuem características físicas e químicas distintas, dependendo da configuração ambiental do lugar onde os mesmos se encontram, podendo ter alto teor de sais, $\mathrm{pH}$ ácido, até com granulometria de muito fina a muito grosseira, por vezes conglomeráticas, micáceas, feldspáticas e apresentando traços de minerais pesados (anfibólios e piroxênios) bem como estratificações plano-paralela e intercruzadas de pequeno a médio porte, de canais fluviais (COSTA; POLIVANOV; ALVES, 2008).

No que diz respeito às rochas e seus solos residuais, o contato entre estes materiais distintos (corpos graníticos e diabásicos), pode torná-los sujeitos aos problemas geotécnicos, como escorregamentos e ruptura de taludes (RAIMUNDO; SANTOS; DIAS, 2002).

De acordo com o IBGE (2007), os solos transportados são formados a partir de depósitos superficiais não consolidados do tipo colúvio, tálus, cones de dejeção, etc.

Os paleossolos podem estar à superfície caso tenham sido expostos pela erosão do manto de sedimentos sobrejacente.

Os vales fluviais variam entre si, que por sua vez,os que se apresentam fechados, com processos erosivos atuantes, podem causar erosão laminar/superficial, movimentação de solos residuais e deposição destes materiais na própria encosta (Lacerda, 2002).

Estes "solos" coluviais, devido à sua natureza porosa, aliada aos macroporos derivados do sistema radicular morto da vegetação em conjunto com a ação de animais, fazem com que estes materiais sejam muito permeáveis (LACERDA, 2002).

De acordo com Lacerda (2002), do ponto de vista geotécnico, os solos residuais são mais resistentes do que os coluviais, no caso de não ocorrer ruptura brusca destes produtos da ação do intemperismo.

No entanto, a denominação destes materiais varia entre as áreas do conhecimento, e por conta disto, optou-se em classificá-los segundo o processo de 
formação (classificação geotécnica) e definiram-se tais materiais, como pode ser observado na tabela 4.

Quanto à definição do "score" do sistema de classificação proposto, como pode ser observado na tabela tipos de solos, os solos com maior resistência ao processo erosivo foi o solo residual jovem e o de menor definição foi o coluvial.

Como foi possível observar, o processo erosivo está associado a uma diversidade de fatores e por conta disto, as variáveis adotadas no sistema de avaliação proposto, limitou-se, no caso dos parâmetros geológicos, aos tipos de substratos e definição dos tipos de solos, já que o comportamento varia entre os vários materiais.

Tabela 4 - Definições os diferentes tipos de solos (MACIEL FIHO, 1994; IBGE, 2007).

\begin{tabular}{|c|l|}
\hline Tipo de solo & \multicolumn{1}{|c|}{ Definiçao } \\
\hline Aluvião & $\begin{array}{l}\text { Formado pela acumulação dos materiais transportados pelo escoamento das } \\
\text { águas nos ambientes fluviais, lacustres, deltáicos e marinhos. }\end{array}$ \\
\hline Aterro & $\begin{array}{l}\text { São depósitos de materiais feitos pelo homem, para fins de engenharia, como } \\
\text { no caso de estradas e demais construções. }\end{array}$ \\
\hline Colúvio & $\begin{array}{l}\text { Depósito de materias sedimentares encontrados nas encostas, por conta do } \\
\text { deslocamento causado pelo próprio peso e por ação das águas pluviais. }\end{array}$ \\
\hline Orgânico & $\begin{array}{l}\text { Formado pelo acúmulo de matéria orgânica, especialmente em áreas } \\
\text { florestadas, ou acumulados pela sedimentação de material geológico rico em } \\
\text { resíduos vegetais. }\end{array}$ \\
\hline Solo residual & $\begin{array}{l}\text { Resultante da intemperização da rocha e que se comporta como solo, } \\
\text { podendo se compartimentado em Solo residual jovem e maduro. }\end{array}$ \\
\hline Eólicos & $\begin{array}{l}\text { Formados pelo acumulo de sedimentos finos transportandos pelo vento, } \\
\text { comum em áreas costeiras e desérticas, podendo formar feições } \\
\text { geomorfológicas do tipo duna. }\end{array}$ \\
\hline Paleossolo & $\begin{array}{l}\text { Material reliquiar, formado em uma paisagem numa época passada e que foi } \\
\text { posteriormente recoberto por sedimentos. }\end{array}$ \\
\hline
\end{tabular}




\subsubsection{Parâmetros geomorfológicos dos problemas geotécnicos ocorrentes em áreas em erosão}

Os rios, enquanto entidades criadas a partir da interação entre o meio externo e interno da terra, são susceptíveis à degradação em decorrência da relação entre o meio biótico e o abiótico, embora o "ser humano" seja o maior predador da natureza, cabe a ele planejar o uso dos recursos naturais sem transformar a Terra em um planeta onde o homem não possa subsistir com boa qualidade de vida (ROSS, 1994).

Neste processo evolutivo das formas de relevo, os rios se transformam de maneiras distintas, em funfção de várias variáveis, onde a sociedade tem exercido um forte papel na transformação da paisagem, como citado por (1994).

Para Barros; Raposo; Magalhães Júnior (2009) as variáveis que denotam os danos ocorridos nos rio, podem ser notados a partir da modificação da formado rio, das características das sequências estratigráficas deposicionais, parâmetros físicoquímicos das águas e variabilidade das vazões.

Neste contexto, a forma do canal fornece informações importantes, como as citadas por Ahmed \& Fawzi (2009), os quais classificam como meandrantes (migração gradual do curso do rio e erosão marginal), embora isto ocorra de forma natural e pelas atividades humanas.

Por outro lado, Cunha \& Guerra (1996) comentam que "umas das formas que o rio encontra para retornar ao equilíbrio anterior refere-se à intensa erosão das margens, assim como a mudança na topografia do fundo do leito".

No que se refere ao modelado do canal, o desenvolvimento da forma "long profile" ou vale cruzado, está relacionado aos seguintes fatores: nível de base (ponto mais baixo de qualquer rio); aumento da descarga rio a jusante; diminuição do diâmetro do material carreado; aumento da descarga implica no aumento da área da seção, se mudança na relação canal $x$ seção, tornando-se assim em um aumento eficiente, e; maior profundidade e transporte de materiais mais finos para a porção 
mais macia do canal, para que a transformação de energia causada pela turbulência diminua, como se observa na figura 3 (WARN, 2011).

Vale salientar que o termo "long profile" ou vale cruzado, corresponde a uma seção muito elaborada ao longo do gradiente rio, desde a nascente à foz, enquanto um perfil transversal é traçado através do vale do rio em intervalos ao longo de seu curso (WARN, 2011).

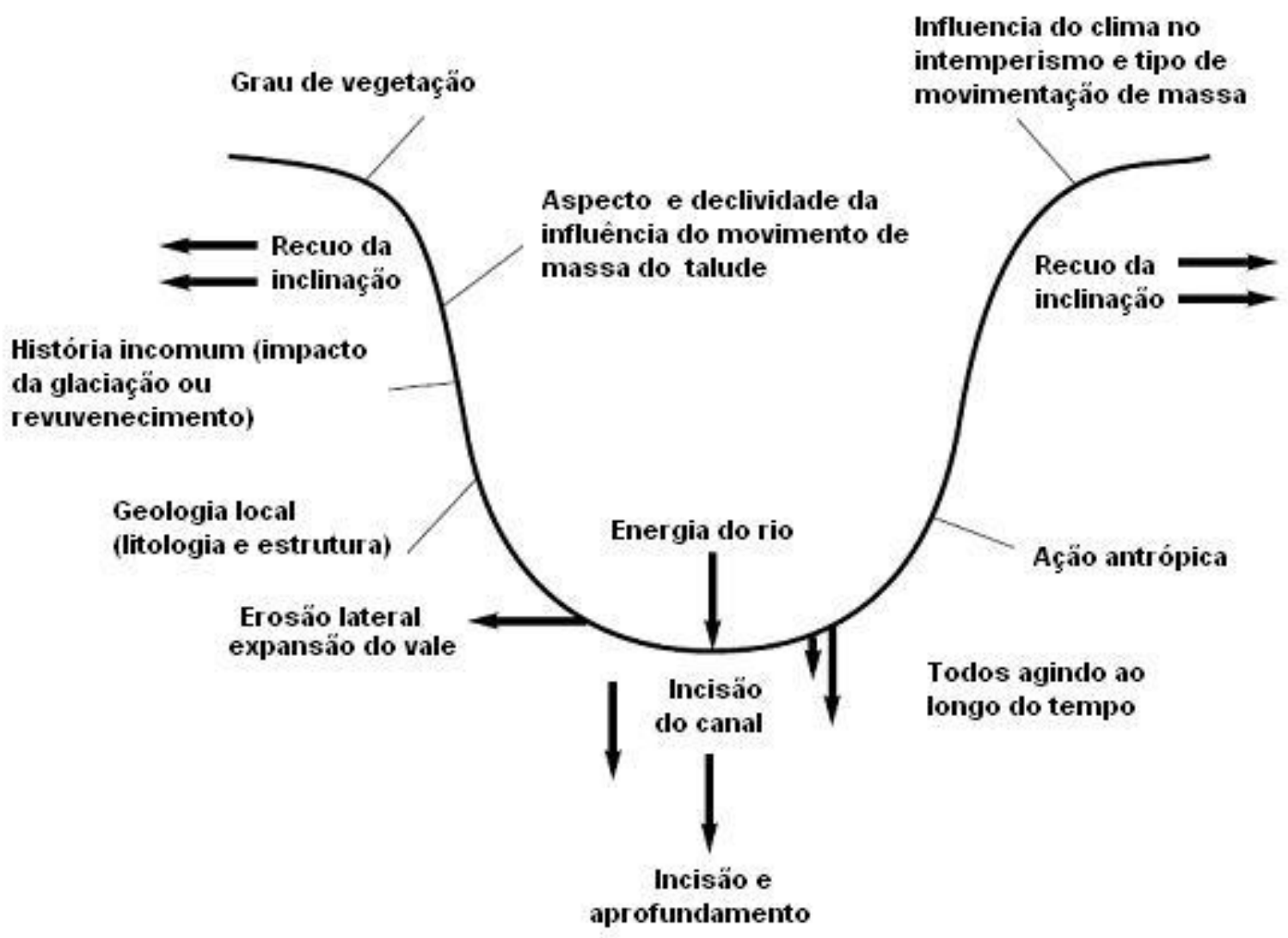

Figura 3 - Fatores que enflunciam no vale cruzado (adaptado em WARN, 2011).

Doeglas (1962) comenta que os rios entrelaçados expõem amplas flutuações em suas descargas, onde tais variações ocorrem por conta das condições climáticas (árido e semi-árido, com precipitações pluviométricas de tempestandes e longos períodos de estiagem; em locais de climas em condições árticas, com longos períodos de degelo e congelamento rápido); impermeabilização do subsolo na área de captura e ao longo do rio; nenhuma água é perdida pela percolação no solo, porém sem nenhuma fonte de água contínua ocorre; vegetação de pequeno porte causando um escoamento superficial forte e baixa evaporação, e gradiente íngreme. 
Quanto aos processos de erosão, transporte e deposição de sedimentos no leito fluvial, Cunha (2001) afirma que os mesmos alternam-se no decorrer do tempo e, que são, espacialmente, definidos pela distribuição da velocidade e da turbulência do fluxo dentro do canal, bem como, são processos interdependentes e que resultam não apenas das mudanças no fluxo, mas também, da carga existente.

A distribuição granulométrica exerce um papel importante da morfologia do rio, para o que Santos, Fernandez e Stevaux (1992) observaram a distribuição granulométrica das barras de canal do Rio Paraná, onde estes autores perceberam as seguintes características:

- Próximo ao canal central - areia média a grossa; presença de estratificação cruzada, acanalada e planar; pouca matéria orgânica, e; forte erosão das margens;

- Próximo às margens - areia fina a muito fina; estratificação cruzada de pequeno porte, marcas de ondas e "flaser"; abundância de matéria orgânica, e; baixa erosão das margens e canais de corte;

- Barra unida às ilhas - areia fina a muito fina; estratificação cruzada de pequeno porte, marcas ondulares e "flaser"; pouco conteúdo de matéria orgânica, e; apresenta baixo nível de erosão.

Um exemplo do uso da geomorfologia na engenharia de rios é o de Gilvear (1999), no qual as características citadas acima podem ser melhor observadas. Quanto à dinâmica das margens, as áreas com bancos estão sujeitas à erosão e os canais mais recentes ficam preenchidos pelo sedimento depositado (SARMA; BORAH; GOSWAMI, 2007).

A velocidade das águas de um rio depende da declividade, volume de água, viscosidade da água, largura, profundidade e forma do canal, bem como, da rugosidade do leito (CHRISTOFOLETTI, 1980).

A declividade influencia no escoamento da água, aumentando a velocidade do fluxo e, consequentemente, uma maior ou menor quantidade de solo arrastado (BIELAVSKY, 2002), transportando as partículas dos solos e nutrientes (PINESE JUNIOR; CRUZ \& RODRIGUES, 2008) ao longo do terreno, embora possa ser condicionado pelo uso e ocupação e pelas características dos solos (REGO, 1978). 
Gilsanz (1996) correlacionou o grau de inclinação das vertentes e os diferentes problemas geotécnicos que podem acontecer, onde a erosão, por exemplo, está relacionada aos ângulos de $2^{\circ}$ a $35^{\circ}$, nas morfologias do tipo fundo de vales (levemente inclinados) a escarpas montanhosas estruturadas.

Segundo Ross (1996) a fragilidade potencial do relevo está relacionada à morfologia, morfometria, arranjo morfol-estrutural, tipo de solo, aspécto climático, bem como, a cobertura vegetal.

Tonello et al. (2006) comentam que a declividade média de uma bacia hidrográfica é importante para o planejamento ambiental e dinâmica hídrica; que a ausência de cobertura vegetal, classe de solo e intensidade de chuvas, dentre outros, associada à maior declividade, conduzirá à maior velocidade de escoamento, menor quantidade de água armazenada no solo e resultará em enchentes mais pronunciadas, sujeitando a bacia à degradação; e que a magnitude dos picos de enchentes ou a menor oportunidade de infiltração e suscetibilidade à erosão dos solos dependem da rapidez com que ocorre o escoamento superficial, que está fortemente relacionado com o relevo.

Gilsanz (1996) considera vertente retilínea como tendo ângulo limitado entre $3^{\circ}$ e $5^{\circ}$; côncava é tida como uma superfície com inclinação constante e crescendo com a altura, ao passo que a convexa decresce com a altura.

A morfologia da encosta é um fator importante e de acordo com Troeh (1965) apud Miranda (2005), existem associações entre ela e os diversos tipos de erosão.

A figura 4 apresenta uma compartimentação taxonômica feita por Ross (1992) sobre as diversas formas de relevo que ocorrem no interior das bacias, como também, suas respectivas formas das encostas, embora tenha adotado a grande maioria delas, por conta de suas especificidade . 


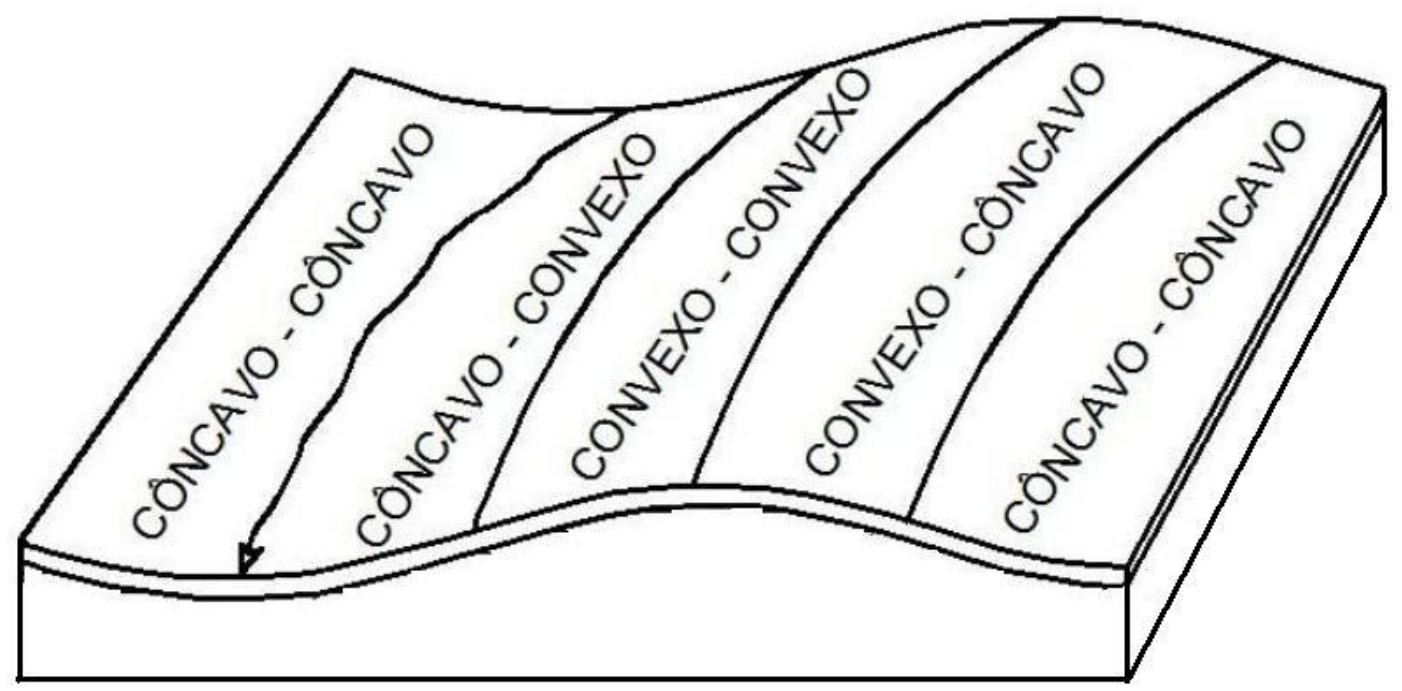

Figura 4 - As diferentes variações das formas das vertentes (adaptado de TROEH, 1965 apud ARAUJO, 2011).

No caso da área de estudo, o local apresenta variações, como sendo retilínea (desembocadura com o Ribeirão das Cruzes), e nas demais áreas, convexacôncava e côncava-côncava.

Outra combinação sobre o relevo, foi feita de forma mais detalhada por Ross (1992), através de uma perspectiva taxonômica geossistêmica, onde a figura 6 , representa os arranjos composicionais, da maior a menos forma de relevo encontrado no interior de uma bacia sedimentar (a área de estudo faz parte de uma bacia sedimentar metamorfisada).

Ross (1992) apresenta uma classificação taxonômica das formas de revelos que podem ser encontradas na natureza, que de acordo com sua posição no interior de uma bacia sedimentar (ver exemplo 6) é segmentada em 4 taxos distintos (Unidade Morfoescultural, Tipos de formas de relevo, Tipos de vertentes e formas de processos atuais). 
15 TAXON - BACIR SEOIMENTAR - UNIONDE MORFOESTRUTURAL

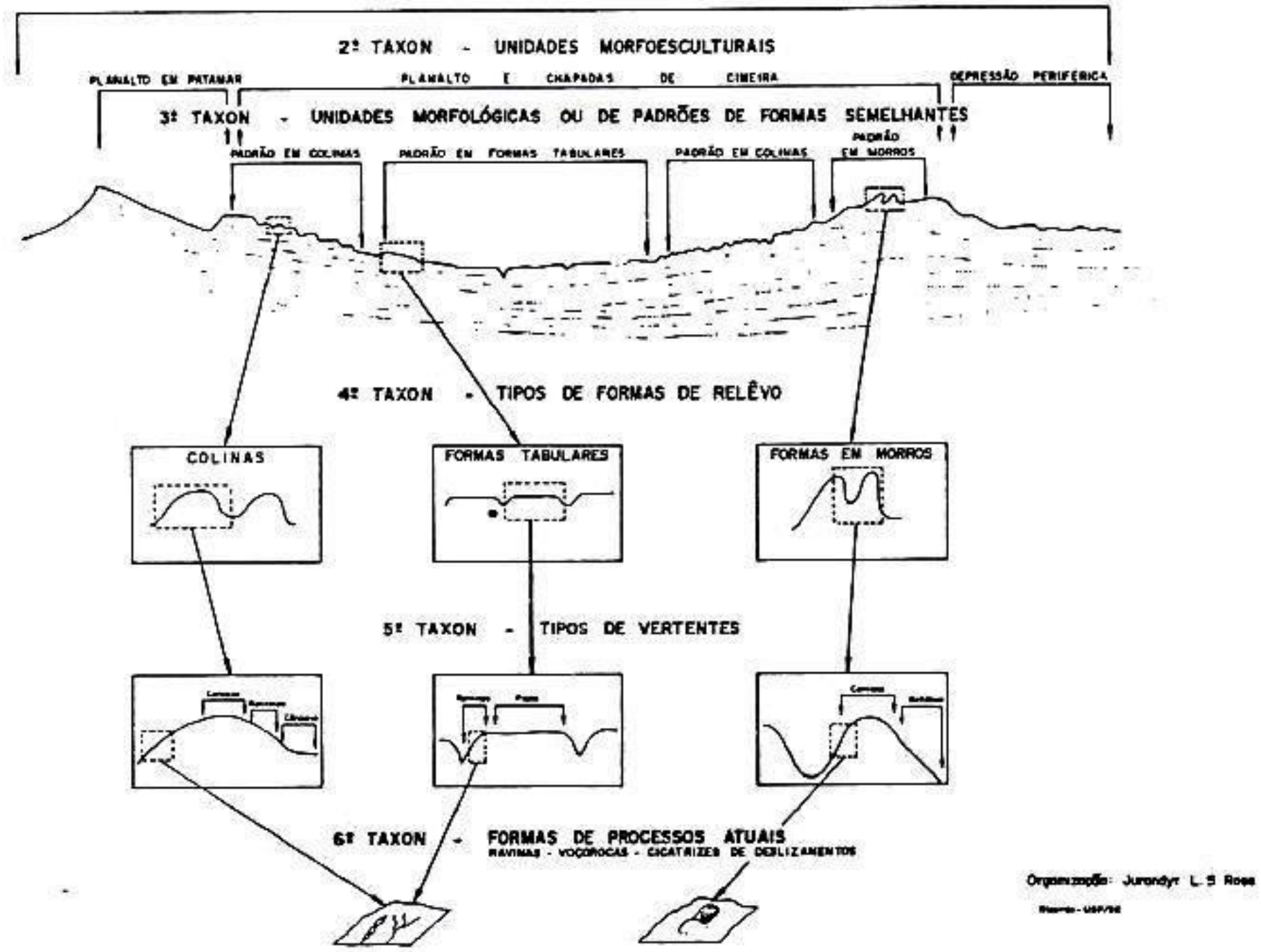

Figura 5 - Classificação taxonômica das diversas formas de relevo (ROSS, 1992). 


\subsubsection{Parâmetros hidráulicos}

A caracterização da atividade hídrica de um determinado rio fornece informações valiosas sobre sua dinâmica, posto que retrate a movimentação de água e de sedimentos em seu interior.

O volume de água que passa entre dois pontos distintos define a vazão de um determinado rio, cuja informação é influenciada pelas condições atmosféricas (aumenta durante os períodos chuvosos e diminui durante os períodos secos) e pelas estações do ano (PALHARES et al., 2007).

Neste sentido, o regime do rio está associado ao clima de uma determinada região, onde a distribuição das chuvas dentro de uma mesma região fornece um caráter perene ao rio, fazendo com que o fluxo hídrico ocorra durante todo ano, ao passo que os rios intermitentes sofrem interrupção das chuvas, de forma proeminente, ao ponto de expor o substrato geológico da drenagem no período de seca (ocorre com certa frequencia na região nordeste do Brasil).

Na comparação entre drenagens, a vazão e o aporte de sedimentos são uma das variáveis mais complexas de se trabalhar posto que os corpos fluviais variam drasticamente uns com os outros, tomando como exemplo o Rio Madeira, cuja área da bacia é de $1,42 \times 10^{6} \mathrm{~km}^{2}$ e uma vazão média anual na foz de $31.200 \mathrm{~m}^{3} / \mathrm{s}$ (ANA, 2004 apud CARVALHO et al., 2010), ao passo que a área de estudo apresenta sua área de $7,81 \mathrm{~km}^{2}$ e uma vazão média de $0,011 \mathrm{~m}^{3}$ (ver tabela 5). Por conta disto, o presente sistema de avaliação teve uma perspectiva mais qualitativa, apesar de se considerar algumas variáveis estatísticas na comparação dos dados entre os diferentes pontos de aplicação do sistema de avaliação em questão (ver tabela 42).

A obtenção dos dados de vazão podem ser realizadas de forma direta ou indireta, como no caso do estudo feito por (MARTINEZ et al., 2007) para avaliação qualitativa do Rio Amazonas, em conjunto com um Espectroradiômetro de Resolução da imagem moderada (MODIS) e técnica computacional (elaboração de um algoritmo de recuperação automática da qualidade da água aplicações de monitoramento, enfocado na carga de sedimentos em suspensão). 
Tabela 5 - Comparação entre áreas de bacias hidrográficas distintas e seus respectivos comprimentos (adaptado de MEADE et al. 1979; CHRISTOFOLETTI, 1983; MANABE \& VESEROLD, 2003; SHIKLOMANOV, 2003; GOULDING; BARTHEM; FERREIRA et al., 2003 apud MARTINEZ et al., 2009; MIKHAILOV, 2010; CARVALHO et al.; 2010).

\begin{tabular}{|l|c|c|}
\hline \multicolumn{1}{|c|}{ Rio } & $\begin{array}{c}\text { Area da bacia } \\
\mathbf{( k m}^{\mathbf{2}}\end{array}$ & $\begin{array}{c}\text { Comprimento } \\
\mathbf{( k m )}\end{array}$ \\
\hline Nilo & 2870000 & 6670 \\
\hline Mississipi & 3300000 & 6260 \\
\hline Amazonas & 6410000 & 7000 \\
\hline Rio Madeira (Porto Velho) & 988.997 & $\mathrm{Sd}$ \\
\hline Córrego das Cruzes & 7,81 & $+-3,3$ \\
\hline
\end{tabular}

Legenda: ${ }^{*}$ = valor média da área da bacia; +- = aproximadamente; $\mathrm{sd}=$ sem dados

A presença de nascentes é de extrema importância na manutenção da água em escoamento no rio;o que sob determinadas situações, em que ocorre um intenso pisoteamento destes locais, a ausência de proteção física, como por exemplo, de proteção da faixa marginal destes locais, pode induzir à erosão do solo, na forma de voçorocamento destes locais, como se observa na figura 7 (a).

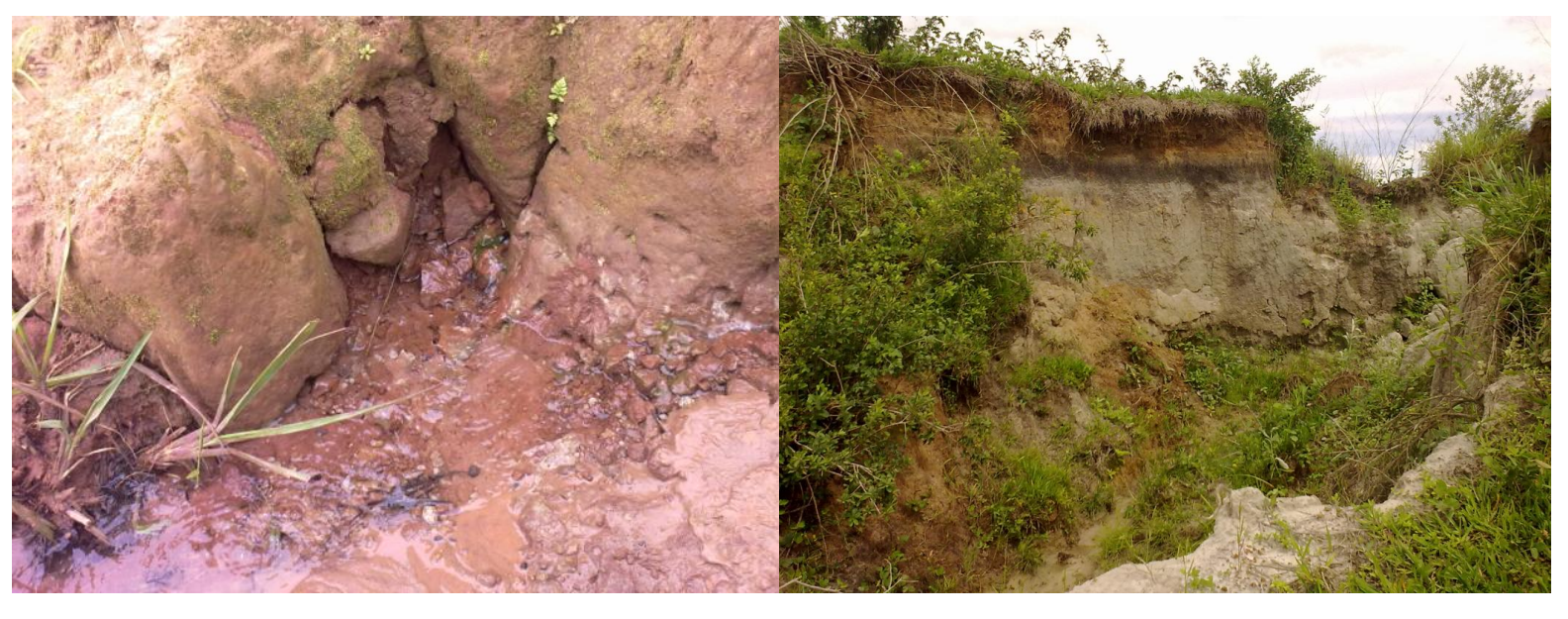

(a)

(b)

Figura 6 - Presença de nascente influenciando na degradação do solo (Autor: E. J. Albuquerque Sobrinho).

O afloramento do lençol freático em uma encosta com forte inclinação, cuja área é utilizada como ponto de acesso do gado à água, gerou a degradação do solo desta margem e acumulação de sedimentos na depressão do terreno, como se observa na figura 7 (b). 
Um importante indicador da dinâmica da disponibilidade dos materiais geológicos transportados pela água, pode ser adotado pelo uso do percentual de sedimentos em suspensão, embora parte do material transportado (os de fração mais grosseira) pode ser executado por tração e saltação, ao passo que os de fração mais fina encontra-se em suspensão.

Quanto maior e mais arredondado forem os agregados transportados pela água, maior é a competência do rio em retrabalhar estes sedimentos disponíveis e por conta disto, definiu-se, arbitrariamente, o percentual de material em suspensão, baseado no material retido no interior de garrafas plásticas de polipropileno de 500 $\mathrm{ml}$, na profundidade média da coluna d'água.

Pião (1995) comenta que: "As medidas de transporte de sedimentos tem sido usado não somente para documentar o transporte de sedimento por si só, mas também, o trabalho da erosão e deposição comparativos em duas ou mais estações".

\subsubsection{Parâmetros pedológicos e geotécnicos}

O processo evolutivo dos rios faz com que estes corpos aquosos evoluam de formas distintas ao longo do tempo e do espaço, cuja interação pode levá-los ao equilíbrio, erosão e/ou assoreamento.

O nível de degradação está relacionado com a forma e a velocidade diferenciada, segundo o material geológico, em decorrência do potencial que os mesmos (solos e rochas) podem ser disponibilizados e transportados ao longo da drenagem.

Neste processo, os agentes climáticos e hidráulicos exercem um papel importante, embora neste tópico fossem destacadas as principais propriedades geotécnicas de solos e rochas que influenciam na análise erosiva destes materiais geológicos tão distintos.

PEJON \& SILVEIRA (2007) defendem que a erosão do solo, incluindo a resultante da atividade antropogênica, representa uma série de problemas ambientais, cujo fator principal influencia na erosão do solo são: origem e tipo do 
solo, talude, nível de água subterrânea, como também, a gestão ambiental. Entretanto as variáveis, conforme avaliadas por PEJON \& SILVEIRA (2007), exercem um papel importantíssimo, o sistema de avaliação proposto por esta tese não ponde incluir, de forma direta, a variável nível de água subterrânea por requerer a presença de indicadores de nível de água, tornando cara a aplicação do sistema proposto, embora se leve em consideração a presença de fontes de água no interior ou proximidade da drenagem.

Já para Silva \& Guerra (2001) e FERNANDES (2003), as propriedades do solo que afetam a erosão são: textura, densidade aparente, porosidade, teor de matéria orgânica, teor e estabilidade dos agregados, $\mathrm{pH}$, mineralogia, presença de agregados, resistência ao cisalhamento, condutividade elétrica e cátions trocáveis permeabilidade e densidade, e às suas propriedades química, biológicas e mineralógicas (MARQUES et al., 1997; BOTSCHEK et al., 2002; MIRANDA, 2005), conta-se ainda com a estabilidade dos agregados em água e sua resistência ao impacto da gota da chuva (ÂNGELO et al., 1984 apud FERNANDES, 2003).

Por conta da grande quantidade de variáveis que influenciam no processo de erosão dos solos, no caso, dos que se encontram nas margens do rio, optou-se em adotar os seguintes parâmetros: textura dos solos; umidade natural; porosidade; $\mathrm{pH}$ dos sedimentos; teor de matéria orgânica; problemas geotécnicos e grau de alteração das rochas por serem variáveis mais fáceis e viáveis de se levantarem, em função dos equipamentos disponíveis nos laboratórios utilizados e da operabilidade dos mesmo.

Vale lembrar que a rocha, ao ser atacada pelos agentes climáticos, modifica-se de rocha para solo, onde quanto mais alterada, maior a capacidade de ser degradada.

A textura está relacionada à distribuição de diferentes frações granulométricas no solo (areia, silte e argila), sendo subdivididos em subclases. "Aparecem as texturas areia, areia franca, franca arenosa, franca, franca siltosa, silte, franco argilo arenosa, franco argilosa, franco argilo siltosa, argilo arenosa, argilo siltosa e argila, que exprimem, de acordo com seus respectivos diâmetros a distribuição relativa das partículas do solo" (VIEIRA, 1988). 
Sua caracterízação baseia-se na sensação táctil-visual que os sedimentos exercem quando em atrito com a mão.

No entanto, é aconselhável realizar esta investigação textural, a partir do ensaio de granulometria (NBR 6502, 1995; NBR 7181, 1984 e NBR 5734, 1989).

Neste sentido, os horizontes dos solos próximos à superficiais apresentam, normalmente, textura argilosa e são quase sempre muito pouco erodíveis, ao passo que os de textura silto-arenosa ou areno-siltosa são extremamente erodíveis (LORANDI et al. 2001; PARZANESE, 1991; NOGAMI \& VILLIBOR, 1995; SOBREIRA, 2000; BACELLAR, 2000; MORAIS, 2003 apud de Paulo; Bacellar; Danderfer Filho, 2005).

A textura do solo implica na capacidade de captação de água pelo solo retido, em um solo previamente saturado, após sua drenagem natural por gravidade, para os quais Sousa Pinto (1976) relacionou diferentes texturas do solo, com sua respectiva capacidade de campo para este fim, como observado na tabela 6.

Por outro lado, nos tratamentos do solo por meio de colheita mecanizada propiciou na redução da taxa de infiltração final em relação à área sob colheita manual de cana queimada, no caso das técnicas de colheita da cultura de cana (TOMASINI et al., 2010).

Tabela 6 - Capacidade de campo para diferentes texturas do solo (adaptado de SOUSA PINTO, 1976).

\begin{tabular}{|l|c|c|}
\hline \multicolumn{1}{|c|}{ Textura do solo } & $\begin{array}{c}\text { Capacidade de campo } \\
(\mathbf{m m} / \mathbf{m})\end{array}$ & PMP (mm/m) \\
\hline Areia & 100 & 30 \\
\hline Areia fina & 115 & 50 \\
\hline Argilo-arenoso & 160 & 115 \\
\hline Argilo-siltoso & 280 & 210 \\
\hline Argila & 325 & \\
\hline
\end{tabular}

Legenda: PMP = Ponto de Murchamento Permanente.

A partir da distribuição e pesagem dos materiais geológicos retidos nas diferentes peneiras, faz-se a classificação destes materiais através do percentual entre o volume total da amostra pela participação das demais peneiras, onde 
prevalece o de maior participação textural embora possa ocorrer a predominância de mais de uma fração, como no caso, franco argilo-siltosos. A classificação destes materiais é feita com o auxílio do gráfico textural (ver figura 7).

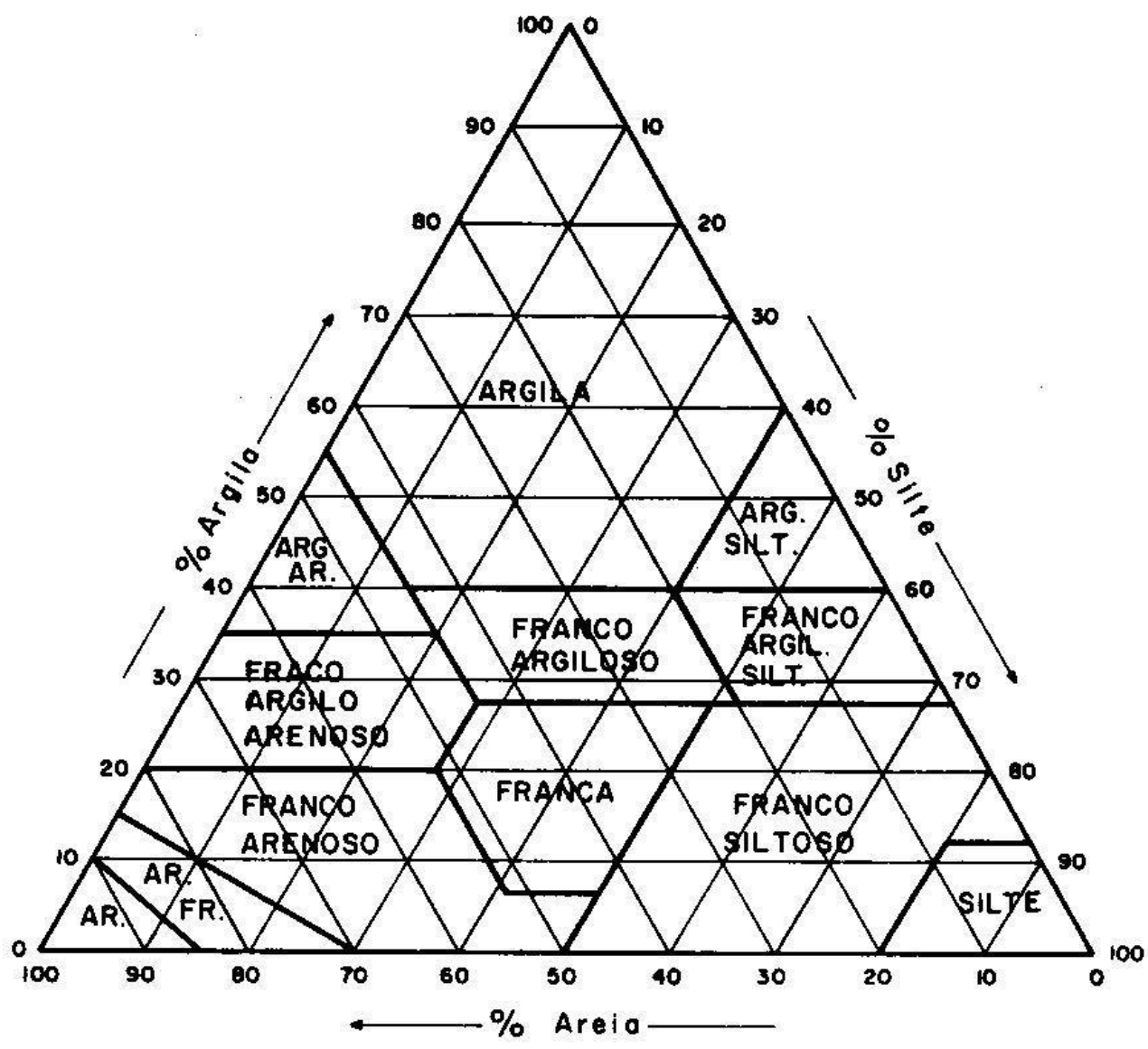

Figura 7 - Gráfico textural do solo (VIEIRA, 1988).

As diferentes frações que compõem os materiais particulados dos solos apresentam propriedades distintas, de acordo com suas respectivas texturas, como se observa na tabela 7 .

O teor de materia orgânica dos solos é de extrema importância, já que melhora as condições físicas e químicas, representadas pela formação de estrutura granular, redução da plasticidade, elevação da capacidade de troca catiônica, entre outras (VIEIRA et al., 1996) e por conta disso, adotou-se as seguintes faixas de conteúdo de matéria orgânica.

Os solos podem apresentar elevada presença de matéria orgânica, mas a quantidade deste material está associada à combinação de múltiplos fatores e pela intensidade, qualidade e tempo de sua composição (matéria orgânica), o que irá 
proporcionar certo nível de equilíbrio, que por sua vez, é regulado por variáveis, do tipo: drenagem, capacidade de retenção de água e típo de vegetação (VIEIRA, 1988).

Como a umidade do solo e o grau de saturação é proporcional à umidade natural do solo em um determinado instante, e esta variável influencia no processo de degradação dos solos, utilizou-se a classificação proposta pela IAEG (1979) apud Maciel Filho (1994).

Vale salientar que diversos problemas de natureza geológico-geotécnicos, podem ocorrer sob certas condições, embora a grande maioria deles, vem sendo criado ou mesmo ampliados por conta das atividades sócio-econômicas.

Tabela 7 - Características das texturas dos materiais geológicos sob diferentes parâmetros geotécnicos (adaptados de YOSHIZANE, 2005).

\begin{tabular}{|c|c|c|c|c|}
\hline \multirow[t]{2}{*}{ PROPRIEDADES } & \multicolumn{4}{|c|}{ TIPOS DE SOLOS } \\
\hline & ARENOSOS & SILTOSOS & ARGILOSOS & TURFOSOS \\
\hline Granulação & Grossa (olho nu) & Fina (tato) & Muito Fina & Fibrosa \\
\hline Plasticidade & Nenhuma & Pouca & Grande & Média a Pouca \\
\hline $\begin{array}{l}\text { Compressibilidade } \\
\text { (carga estática) }\end{array}$ & Pouca & Média & Grande & Muito Grande \\
\hline $\begin{array}{l}\text { Compressibilidade } \\
\text { (carga vibrada) }\end{array}$ & Pouca & Média & Grande & Muito Grande \\
\hline Coesão & Nenhuma & Média & Grande & Pouca \\
\hline $\begin{array}{l}\text { Resistência ao } \\
\text { Solo Seco }\end{array}$ & Nenhuma & Média & Grande & Média a Pouca \\
\hline Observou-se & $\begin{array}{c}\text { Tato } \\
\text { Visual }\end{array}$ & $\begin{array}{c}\text { Tato } \\
\text { Quando seco, se } \\
\text { esfarela } \\
\text { Se imergir uma } \\
\text { porção, seca na } \\
\text { água desagrega }\end{array}$ & $\begin{array}{c}\text { Tato } \\
\text { Se molhar, torna- } \\
\text { se bem plástico } \\
\text { Se imergir na } \\
\text { água, mesmo } \\
\text { depois de seca, } \\
\text { não desagrega. }\end{array}$ & $\begin{array}{c}\text { Pela cor escura } \\
\text { (preta) } \\
\text { Quando molhado, } \\
\text { é bem plástico. } \\
\text { Nota-se ser um } \\
\text { material fibroso } \\
\text { cheiro }\end{array}$ \\
\hline
\end{tabular}




\subsubsection{Problemas geotécnicos ocorrentes em rios e em suas margens}

Os problemas comumente observados no interior dos rios e no interior das bacias hidrográficas estão associados às condições naturais do local quanto ao uso e ocupação do entorno. No entanto, do ponto de vista geotécnico, pode-se citar as seguintes questões (SOUZA PINTO \& HOLTZ, 1976; ZUQUETTE,1993; MINISTÉRIO DAS CIDADES, 2007; CORREA \& SOUZA FILHO, 2009; COSTA et al., 2009; LÉVY et al., 2011):

- $\quad$ Alteração física do canal;

- Assoreamento do canal devido à entrada de materiais particulados do entorno e/ou acumulados durante a redução do nível de água do canal;

- $\quad$ Erosão de suas margens pela ação do fluxo em escoamento;

- Inundações no leito maior e excepcional, que dependendo do tipo de ambiente, pode causar danos sócio-econômicos e ambientais;

- Movimentação de massa;

- $\quad$ Problema de erosão do leito, quando presença de pilares intermediários de pontes e;

- Recalques provenientes da dissolução de rochas calcárias pela água subterrânea;

- Remobilização dos sedimentos do canal causada pela circulação de embarcações nos canais fluviais devido à ondulação das águas causada pela movimentação de embarcações, dependendo da largura e profundidade do canal, como também pelo porte da embarcação.

- Solapamento basal devido ao escoamento da água nas proximidades das margens de elevada inclinação, que por sua vez, escava o contato rio/margem ao ponto de promover discontinuidade do maciço (rochoso/terroso) e com seu próprio peso, cai sob efeito gravitacional ou mesmo potencializado pela circulação sobre este local, no caso da área de estudo, foi potencialização pela circulação do gado de um ponto a outro.

O tipo de solo exerce um papel importante no processo erosivo, mas empregar a classificação pedológica destes materiais é um tanto prejudicial para os locais 
constituídos por solos e materiais transportados, por isso, optou-se pela classificação com base no processo de formação, sob o ponto de vista geotécnico.

Os solos coluviais são formados pelo acúmulo de materiais geológicos anisotrópicos de frações diferentes e podem ocorrer no sopé das encostas e segundo Lacerda (2002), tais depósitos de colúvios podem apresentar uma grande variedade de tipos de solos, frações variadas dos materiais geológicos, podendo atingir espessuras de aproximadamente $30 \mathrm{~m}$.

Os depósitos formados por aterro em área de aterro rodoviário, de acordo com Maccarini (2002), apresentam descontinuidades dos mesmos, gerando trincas; se houver implantação de obras rodoviárias sobre aterro antigo apresentará incompatibilidade das deformações verticais, onde as tais trincas apresentam-se paralelamente ao eixo da rodovia; não apresenta ligação na direção diagonal ao eixo, com os bordos da mesma, como também, não apresentam desnível ou degrau entre as margens opostas das mesmas.

Quando aos aterros provenientes de mineração, os mesmos podem promover impactos distintos ao meio, segundo as condições geológicas do minério explorado e a forma que foram dispostos seus bota-foras na natureza Como no caso da atividade de mineração de carvão a céu aberto, no município de Lauro Muller, Santa Catarina, onde podem ocorrer deficiências no processo de construção (disposição inadequada dos materiais e resíduos da mineração utilizados e nas áreas adjacentes ao empreendimento, como também, o modo de construção do solo influencia na qualidade ambiental do solo construído (CAMPOS; ALMEIDA; SOUZA, 2003).

Miguel, Vieira e Grego (2009), ao estudarem os efeitos da intensificação do pisoteio do gado sobre as propriedades físicas do solo, comentam que a taxa de infiltração de água no solo apresenta estrutura de dependência espacial, que aumenta em função da intensidade de pisoteio.

A erosão superficial constitui como o primeiro estágio do processo erosivo, evoluindo conforme as ravinas são formadas, podendo culminar na formação de voçorocas, compreendendo o estágio terminal do processo. Ela é responsável pela remoção das partículas coloidais e dos íons em solução, reduzindo seu potencial produtivo de biomassa, pela baixa fertilidade (MENDES, 2006). 
Diferentes problemas geotécnicos podem ocorrer sob diferentes tipos de uso e ocupação. Nas áreas urbanizadas, em especial, nas localizadas em regiões de topografia com declives acentuados e em conjunto com constituição geotécnica de solos e rochas desfavoráveis, podem ocorrer, por exemplo, problemas de deslizamentos de terra, ruptura de encostas, queda de blocos, Solifluxão, etc. Como já ocorridos nas porções montanhosas da Pasigh/ Índia (PRAKASH, 2002) e na região Serrana do Estado do Rio de Janeiro/Brasil (SILVA; LOUREIRO; SILVEIRA, 2010).

Vale salientar que, em decorrência da densidade populacional, os impactos sócio-ambientais são potencializados, gerando danos ambientais e sociais.

No caso de recalques (deformações do maciço com movimentação descendente), podem ocorrer por variação do lençol freático sobre diversas obras de engenharias, como por exemplo, edifícios implantados em rochas cársicas sob processo de dissolução hidrogeoquímica destas rochas. Embora Albuquerque Sobrinho (2006) tenha observado tais fenômenos induzidos pela injeção de calda de cimento no solo ("jet grouting" e CCPh).

Com relação à degradação ambiental dos solos, a vegetação atua minimizando os problemas geotécnicos, embora o processo de reestruturação da vegetação florestal no controle dos processos hidrológicos superficiais darem-se de forma lenta, que de acordo com Negreiros \& Coelho Netto (2009). Estes pesquisadores indicaram que o intervalo de tempo entre a degradação ambiental causada por um deslizamento ocorrido há mais de 18 anos, em uma área florestal secundária, sob condição de terreno íngreme, ocorreu de forma lenta, possivelmente por causa da intensa lavagem superficial no interior da clareira através do fluxo adicional provido pela estrada, propicionado maior ação de ventos intensos sobre a floresta adjacente, alimentando a degradação do entorno imediato como um possível efeito de borda, atrasado em relação ao processo de revegetação nas bordas.

Menescal, Figueiredo e Franco (2005) comentam que as chuvas em áreas urbanizadas precipitam-se sobre superfícies impermeabilizadas, que escoa para os bueiros e atingem os cursos fluviais. Neste sistema, a infiltração é praticamente nula e uma das consequuências disso é a alta frequuência de inundações após os temporais.No entanto, estes autores ainda afirmam que a intensidade e duração das 
precipitações pluviométricas que ocorrem no interior das bacias, bem como, fatores fisiográficos do tipo área da bacia, seu formato, declividade, tipo de solo, cobertura vegetal, dentre outros, são os fatores principais causadores destas enchentes.

"Piping" é um dos tipos de erosão que ocorre no interior do maciço terroso, quando a água de infiltração escava o solo em horizontes inferiores, formando túneis internos de diâmetros variáveis e formação de voçoroca (NASCIMENTO \& GARCIA, 2005).

Esta erosão interna geralmente promove o abatimento dos materiais arenosos, concentrando as águas das chuvas, que podem evoluir para feições erosivas desdes sulcos à voçorocas, com extensão de até $150 \mathrm{~m}$, no caso da Bacia do Córrego Tenente, Mariluz - PR (SOUZA; GASPARETTO; NAKASHIMA, 2008).

O estudo feito por NASCIMENTO \& GARCIA (2005) indicou que o controle estrutural no terreno pode influenciar na dinâmica das águas subterrâneas, facilitando o desenvolvimento de "pipping".

\subsubsection{Parâmetros Ecológicos Relacionados aos Processos de Erosão}

A vegetação exerce um importante papel na preservação da dinâmica ambiental, já que a mesma vem sendo usada para reduzir a erosão do solo, estabilização da margem e leito de rio ou para proteger muros de arrimo, bem como, proteger bancos de areia das forças da água (GRABECHT, 1981 apud SCHLUTER 1984 EVETTE et al., 2009).

Embora a presença de vegetação tenha um papel importante na diminuição do escoamento superficial, a retirada da vegetação ribeirinha pelas atividades sociais feitas pelo setor "produtivo" é responsável pela degradação das matas ciliares, como citadas por Rodrigues \& Gandolfi (2001), expõem os materiais geológicos que compõem os solos causando a erosão das margens dos rios como também modificação do canal.

Segundo Bertoni \& Lombardi Neto (1999), a cobertura vegetal atua na proteção direta contra o impacto das gotas de chuva, dispersando a água, interceptando-a e evaporando-a antes que atinja o solo; na decomposição das raízes das plantas que, 
formando canalículos no solo, aumentam a infiltração da água; melhoramento da estrutura do solo pela adição de matéria orgânica, aumentando assim sua capacidade de retenção de água; diminuição da velocidade de escoamento da enxurrada pelo aumento do atrito na superfície.

Segundo Rodrigues (1982), apud Miranda (2005), a ausência vegetal ribeirinha causa interrupção brusca do efeito estabilizador da floresta, expondo o terreno a novas condições; alteração das funções exercidas pela vegetação, como interceptação, retenção, evapotranspiração, etc.; desaparecimento do horizonte húmico, aumentando assim a infiltração; e diminuição da resistência mecânica do solo pelo enfraquecimento do sistema radicular.

Desta forma, os diferentes tipos de vegetação, localizadas na faixa marginal, constituem corredores ecológicos e possibilitam a preservação da biodiversidade e dos recursos hídricos (AVILA et al., 2011) evitam o surgimento de feições erosivas (SOUZA; GASPARETTO; NAKASHIMA, 2008).

Como a capacidade do solo está associada a sua capacidade de infiltração , a cobertura vegetal exerce um papel importante neste processo, já que, quando sua densidade arbórea é dita como densa, favorece a infiltração, pois dificulta o escoamento superficial da água. Ao final das precipitações pluviométricas, suas raízes retiram a umidade do solo, possibilitando maiores valores da capacidade de infiltração no início das precipitações (MARTINS, 1977b).

As áreas em que estes corpos vegetais estão localizados e a ocorrência ou não de espaçamento entre elas, podendo facilitar ou não, o escoamento gerado pelas precipitações pluviais em terreno acidentados (BERTONI \& LOMBARDI NETO, 1999), onde isto pode ocorrer fortemente em cultivos em faixas em terrenos inclinados, em encosta abaixo.

No caso da vegetação que compõem as matas ciliares, Ab'Saber (2001) exemplificou que a retira de vegetação no Vale do Jequitinhonha (Estado de Minas Geriais), devido ao "remeximento das áreas aluviais contidas nos diques marginais para fins de garimpagem de diamantes e ouro, perturbou numerosos setores das planícies de modo irreversível, ocasionando aceleração dos processos de assoreamento, provocando o escoamento mais rápido nas épocas chuvosas, em paralelo com fortes oscilações sazonárias no rio abaixo". 
Por outro lado, a respeito da ocorrência de vegetação ao longo da drenagem em áreas urbanizadas, Wolman (1967) afirma que se a vegetação se estabiliza nas barras do canal, estes, sendo de constrição, ou os bancos podem localmente erodir, acompanhado de um aumento no número de inundações nas constrições do canal. Após a conclusão das ruas e de sistemas de esgotos derivados do decréscimo de sedimentos enquanto o escoamento superfícial aumenta rapidamente. Após a conclusão das ruas e dos sedimentos provenientes de sistemas de esgotos, enquanto diminui a rapidez de escoamento da bacia e aumenta o escoamento rapidamente. As barras de canal e a vegetação podem ser removidos pelos fluxos de água límpida. Ao mesmo tempo, a ausência de um suprimento novo de sedimentos pode resultar na erosão progressiva do canal sem deposição concomitante.

Quanto ao papel da vegetação no fluxo de canais, o estudo experimental realizado por Afzalimehr; Sui; Moghbel (2010) indicou que a redução do fluxo hídrico na seção do canal promove a diminuição da vegetação nas paredes do canal causando um aumento no coeficiente de rugosidade, como também, a presença de cobertura vegetal nas paredes do canal causa o desvio da distribuição de tensão linear de Reynolds de condição de fluxo uniforme.

A vegetação ribeirinha tem a função de proporcionar a preservação dos mananciais hídricos fluviais, os quais desempenham importante função social e ecológica por meio do abastecimento público, irrigação, uso industrial, preservação da biodiversidade e manutenção do equilíbrio ecológico (AVILA et al., 2011).

A vegetação localizada nas margens dos rios e em suas zonas baixas inundáveis exerce uma amortização da capacidade de escoamento (SOUZA PINTO \& HOLTZ, 1976), causando uma diminuição da capacidade de transportar os materias geológicos rio abaixo, oferecendo assim, a proteção e minimização dos processos de assoreamento que pudessem ocorrer em função de processos erosivos e de transporte de materiais, induzidos ou desencadeados durante a implantação do empreendimento, se houver alteração de usos (MOROZ; GOUVEIA; ROSS, 2007).

De acordo com Fernandes (2000), a vegetação que compõe o canal fluvial é compartimentada conforme o ajustamento da mesma ao meio hídrico, como segue: 
1) Livres/ natantes (limnóticos) - são vegetações que se encontram totalmente livre (não fixadas ao leito), podendo estar flutuantes na superfície da água, podendo ser transportadas pela ação dos ventos por conta da movimentação das camadas exteriores do líquido que as suportam ou mesmo imerso em meio a água, recebendo menor influência dos diferentes fatores externos; e

2) Fixos/ radicantes (pedônicos) - Desenvolvem um sistema radicial regular, ajustado à condição hídrica, embora mantido no interior do substrato lamoso, hídricamente saturado, e podem ser ainda submersos (permanecem inteiramente no meio líquido); oscilantes (possuem folhas distendidas na superfície da água, com pecíolos longos e limbos amplos, de forma orbicular ou equivalente, que se agitam ondeamente ao movimento das camadas superiores da água) e ainda; emergentes (encontrados, normalmente em águas rasas, com sistema subterrãneo bem desenvolvido, que se eleva no ar parte de seu sistema vegetativo, ultrapassando o nível superficial da água em pequena proporção).

Embora exista uma certa variação de espécie entre as vegetações localizadas no interior do canal, no sistema de avaliação aqui proposto não chegou ao nível de distinção entre elas, ao ponto de se considerar, apenas, a posição delas no canal, indiferente do tipo de espécie que ocorra, visando facilitar a aplicação do sistema aqui em proposição, posto que requer um conhecimento específico quanto ao tema.

Paradoxalmente, as matas ciliares podem funcionar, também, como uma zona tampão, posto que a vegetação, diminui ou impede o aporte de sedimentos e solutos para os corpos d'água, podendo atuar como reservatórios de poluentes, disponibilizando grande carga aos mananciais quando saturados (NEVES, 2005).

A serrapilheira apresenta uma importante participação na diminuição do processo erosivo, no caso, das matas ciliares e das encostas.

Abreu (2006) comenta que o tapete de serapilheira é o resultado da interação constante entre a deposição de serapilheira e sua decomposição ao longo do tempo e que influencia na capacidade de retenção das águas provenientes das chuvas. Melos; Sato \& Coelho Netto (2010) compararam esta capacidade entre serrapilheira de florestas distintas (eucalipto e florestas ombrófilas), em que daquelas oriundas de reflorestamento por eucalípto e serem mais homogêneas que a segunda, decresceu quando ocorreu um maior aporte de serrapilheira. 
No caso da área de estudo, a mata ciliar, simplesmente não existe, embora inespressivos fragmentos arbóreos sejam encontrados, com apenas 20 indivíduos segmentados em pequenos trechos vegetacionais, ao longo de toda faixa (marginal.

\subsubsection{Uso e ocupação do solo}

O desenvolvimento do uso da terra e dos recursos naturais, como também a constituição natural da hidrologia de um rio da bacia, dependendo da inter-relação entre estes fatores, pode resultar em diversos problemas ambientais (RICKERT \& HINES, 1978).

O fator social tem contribuído muito no processo de degradação ambiental, incluindo os processos erosivos, devido ao, entre outras coisas, uso e ocupação desordenado dos diferentes espaços natural e artificial (ALBUQUERQUE SOBRINHO, 2001; ALBUQUERQUE SOBRINHO \& ANDRADE MEIRELES, 2004; ALBUQUERQUE SOBRINHO et. al., 2010; MORELLI et al., 2012). Não obstante, os impactos reflitam os diferentes tipos de uso e ocupação.

Enquanto produtos da modificação da economia, as cidades aglotinam em espaços e em ambientes diferentes, um número relativamente grande, como das das cidades de médio e grande porte, cuja dinâmica social inclui além da moratida, a circulação de bem e serviços, requerendo intervenções do solo para que as atividades sociais se materializem, na forma de bem e serviços.

Isto se deve ao fato de que as atividades humanas, quando feitas sem os devidos cuidados, seguido de ausência de práticas conservacionistas e mitigadoras, exercem um papel importante na aceleração da degradação ambiental, que sob determinadas situações, acelera o processo natural de erosão dos solos e demais morfologias do relevo, que inclui os rios.

Por outro lado, o setor industrial requer um alto grau de planejamento na instalação de fábricas, já que necessitam, de energia elétrica, vias para circulação de insumos e de seus produtos manufaturados, transporte público, entre outras infra-estruturas.. Estas podem induzir ou mesmo acelerar o processo de modificação do meio físico. 
Vale salientar que, o destino final destes materiais desprendidos e carreados pelos agentes atmosféricos são os corpos d'água, os quais têm a sua característica hidráulica alterada pela deposição de materiais no leito, reduzindo assim a capacidade de transporte de água (COSTA, 2009).

As diferentes formas de uso e ocupação ao longo das bacias hidrográficas e demais drenagens podem induzir ou mesmo acelerar o processo de erosão, tanto no próprio canal (leito menor) quanto no solo localizado em seus leitos (maior e excepcional), como em uma expressiva área de uma bacia hidrográfica.

Zancopé (2004) comenta que os efeitos da prática antrópica na bacia hidrográfica, em diversas escalas, podem causar transformações fluvio-ambientais nos processos de transporte e sedimentação dos rios, comprometendo a disponibilidade dos recursos hídricos existentes.

Estas atividades são realizadas para fins diversos, como nas áreas urbanizadas, rurais, industriais, mistas. No entanto, definiu-se com mais fatores impactantes as áreas mistas, por terem atividades diferentes no mesmo espaço, e um fluxo de pessoas maior, especialmente quando mista em uso rural (população permanente) e rural (embora menor densidade populacional, as atividades econômicas no campo têm um forte impacto no ambiente, especialmente quando sofrem por problemas de desmatamento, uso de maquinário pesado, dentre outros. No entanto, quando feito com planejamento e gestão ambiental, os danos são minimizados.

Também as infra-estruturas enterradas, como tubulações, sob certas condições de chuva e de relevo podem ser indutoras de processos erosivos, como observados por Ferreira \& Pejon (2004), em uma tubulação de águas pluviais.

Os túneis, enquanto obras construídas no interior dos maciços (rochoso e terroso), são excelentes infra-estruturas no que diz respeito aos impactos criados ao meio ambiente, embora sujeitos aos recalques diferenciais em edificações e construções localizadas nas proximidades da obra, durante sua execução, como observado por Albuquerque Sobrinho \& Polivanov (2005) e Albuquerque Sobrinho (2006); podendo ocorrer, ainda, problemas relacionados à disposição de bota-fora, que normalmente é feito em aterros ou reaproveito do mesmo como material de construção. 
No caso dos rios, os impactos criados ao ultrapassar estes ambientes, são praticamente nulos ou de curta duração, dependendo da técnica construtiva adotada.

A figura 8 mostra uma das formas de reforço de construções, visando minimizar os danos que podem ser gerados pelo escoamento pluvial (parte superior da via), onde suas margens, no caso, a porção direita, é formada por cortina atirantada e gramínias, para diminuir a capacidade do talude ser erosido.

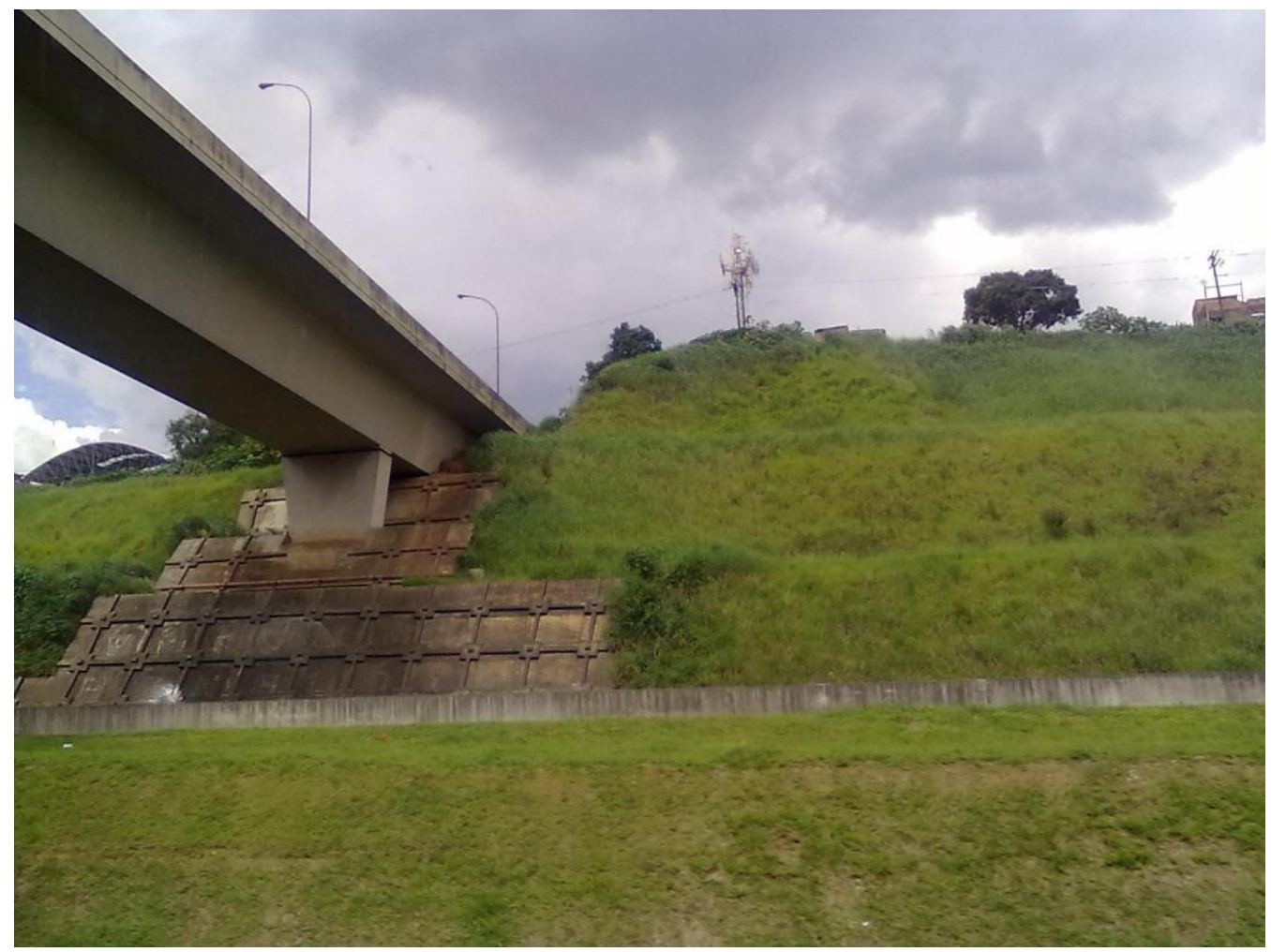

Figura 8 - Exemplo de intervenção geotécnica para estabilização e reforço de maciço com via (Autor: E. J. Albuquerque Sobrinho).

O uso sustentável do solo é vital para que os impactos no meio sejam minimizados e em áreas urbanizadas, o uso de infra-estrutura voltada às águas residuárias são indicativos de tais práticas, embora a impermeabilização seja o oposto, embora planejamento e práticas que causam a impermeabilização ocorram em paralelo.

Nascimento (2011) comenta que podem ocorrer impactos ambientais diretos e indiretos nos exutórios das bacias hidrográficas, dependendo do uso e ocupação do solo.O referido autor cita como impactos diretos: a retificação, dragagem do rio e 
barramentos indevidos, e indiretos, o desmatamento, impermeabilização de superfícies e mudanças no uso da terra; podendo ocorrer modificações nas propriedades físicas e estruturais dos solos, na precipitação e temperatura.

No entanto, o uso desenfreado do solo por atividades agrícolas, de modo geral, causa o empobrecimento do solo, requerendo assim, o manejo e conservação do manto de intemperismo através de práticas mitigadoras, como a calagem e uso de demais insumos agrícolas, como o uso de fertilizantes, defensivos agrícolas e deposição de matéria orgânica.

Estas práticas podem gerar resultados conflitantes, como melhoramento do solo e eutrofização dos corpos hídricos em detrimento do carreamento destes materiais usados no manejo, que podem ser transportados através dos corpos hídricos durantes as precipitações pluviométricas, incluindo ainda, os pesticidas e demais produtos.

As atividades relacionadas às práticas agropastoris, do extrativismo vegetal e mineral, por obras de engenharia, as diferentes formas de uso e ocupação dos recursos hídricos e de suas margens, que causam, dentre outros impactos, a aceleração do processo natural de erosão como observada no estudo realizado (2009) para a região de Sohan/Egito.

Nesta região, o uso da terra se dá através de atividades agrícolas, exploração das diferentes atividades econômicas associadas ao turismo da comentada região, incluindo os processos de urbanização e de recreação, onde os autores já citados (AHMED \& FAWZI, 2009; ALMEIDA et al., 2010) comentaram que tais práticas, ainda relacionadas às alterações no próprio rio (obras de engenharia), causaram problemas diversos, como erosão marginal, redução das áreas agricultáveis localizadas próximas às suas margens e/ou mesmo o desaparecimento de ilhas fluviais, que repercutiu na produção na agricultura.

$\mathrm{Na}$ realidade brasileira, Simon (2007) expôs as alterações causadas pela dinâmica sócio-econômica na bacia do Arroio Santa Bárbara (Pelotas, RS), por um período de 53 anos, onde o citado autor levantou os seguintes problemas: o avanço das áreas agrícolas sobre zonas de pastagens proporcionou, no setor de nascentes desta bacia, causando alterações morfohidrográficas vinculadas, sobretudo ao controle indireto dos elementos do sistema ambiental e alterações na dinâmica 
fluvial desencadeada a partir da construção do Reservatório Santa Bárbara, onde impactos podem provocar mudanças nos cursos à jusante.

Quanto ao papel que as vias de circulação (estradas, rodovias e demais vias) exerce na degradação ambiental, em que os impactos causados pela ocupação e degradação do meio físico da região amazônica apontaram que os modelos de regressão para o desmatamento e pastagem feitos por Espindola et. al. (2012) foram determinantes quanto ao papel que a distância das estradas tiveram e foram observadas e mais influentes em 1997 do que em 2007; incluindo ainda a alteração do uso do solo, de floresta para agricultura, embora feita de forma diferenciada entre os Estados inseridos nesa porção espacial do Brasil, onde o processo de mecanização feita pelas práticas agropecuárias aceleraram à degradação ambiental, especialmente no Estado do Mato Grosso.

Assim, as áreas urbanas, sob condições ambientais desfavoráveis, estão sujeitas a diversos problemas sócio-econômico-ambientais.

Diferentes problemas oriundos de condições ambientais desfavoráveis podem ocorrer tanto em áreas ocupadas e habitadas pelo homem quanto sem a sua presença, porém os efeitos, quando o componente humano está inserido são ampliados.

Nos E.U.A, uma das modificações do meio físico ocorre durante o processo de urbanização da região metropolitana de Baltimore , onde Wolman (1967) elaborou um levantamento dos efeitos causados, e comparando com os usos agrários e florestais antes do desenvolvimento urbano, então as mudanças sequenciais que ocorrem enquanto o desenvolvimento urbano que ocorreu na bacia; o que pode ser esperado, segundo o autor, é uma alteração significativa para que o equilíbrio das formas resultem na eventual criação de novas condições de equilíbrio.

Sinteticamente, Tucci (1995) apud Tucci (1997) cita os principais impactos causados pelo processo de urbanização, como o aumento do escoamento superifical, redução da evapotranspiração do escoamento subterrâneo e lençol freático aumento da produção de material sólido e da alteração da qualidade das águas superficiais.

Pons \& Pejon (2008) comentam os diferentes impactos sócio-ambientais causados pelo processo de urbanização da cidade de São Carlos/SP (Brasil), 
associados aos diferentes tipos de uso e ocupação do tecido urbano, com pode ser observado na tabela 8.

Tabela 8 - Impactos ambientais causados pelo uso diferenciado do solo na cidade de São Carlos/SP (PONS \& PEJON, 2008).

\begin{tabular}{|c|c|c|}
\hline \multicolumn{3}{|c|}{ Diferentes tipos de uso e ocupação } \\
\hline Urbano & Agrário & Industrial \\
\hline $\begin{array}{l}\text { Desmatamento das áreas de } \\
\text { nascente; } \\
\text { Erosão, assoreamento e } \\
\text { inundações atuantes, onde as } \\
\text { porções mais vulneráveis } \\
\text { ocorrem nas cabeçeiras do Rio } \\
\text { Mojolinho e Córrego do } \\
\text { Gregório e ocupação urbana, e; } \\
\text { Processos erosivos intensos } \\
\text { são observados no bairro } \\
\text { Cidade Aracy. }\end{array}$ & $\begin{array}{l}\text { Ocupação das cabeçeiras do } \\
\text { Rio Mojolinho e Córrego do } \\
\text { Gregório para fins de atividade } \\
\text { agrária. }\end{array}$ & $\begin{array}{l}\text { Áreas com exploração } \\
\text { mineração; } \\
\text { Locais abandonados são } \\
\text { considerados de risco à } \\
\text { população e exposição dos } \\
\text { materiais geológicos às } \\
\text { condições atmosféricas; } \\
\text { Cavas profundas } \\
\text { abandonadas, e; } \\
\text { Atividades de mineração } \\
\text { ativas }\end{array}$ \\
\hline
\end{tabular}

O estudo feito por Espíndola; Brigante; Eler (2003) citaram os principais impactos associados aos diferentes tipos de atividades econômicas, que ocorrem ao longo dos cursos fluviais, como pode ser observado na tabela 9. Onde é possível observar que os processos erosivos ocorrem, principalmente, nas atividades de mineração (manganês e portos de areia), ao longo do Rio Mogi-Guaçu (Estado de São Paulo); embora na área de estudo, o uso até meados do ano de 2011 tinha utilidades específicas, predominantemente, pastagem, após o comentado período mudaram a atividade econômica e o uso do solo para o plantio de cana-de-açúcar.

A modificação de áreas florestais em campos agricultáveis tem causado perdas irreparáveis dos solos (PIMENTEL et al., 1995), sendo uma das maiores causas pela devastação de floresta, posto que a modificação de áreas florestais em áreas utilizadas para agricultura, ao serem degradadas, são abandonadas, transformando florestas em áreas convertidas para produção agrícola (MYERS, 1989 apud PIMENTEL et al., 1995). 
A produção em massa de alimentos tem provocado impactos sócio-econômicos e ambientais, valido não só para os industrializados e cultivados quantos os de produção animal, tais como os bovinos e caprinos (Sociedade Vegetariana Brasileira, 2007).

Sobre a produção de alimentos no campo e seus impactos gerados pelo uso agrícola dos solos, isso pode causar, além da erosão do manto de intemperismo, o fluxo lateral de nitrogênio e fósforo, cujo impacto seria similar à aplicação de fertilizantes e remoção de culturas (QUINTON et al., 2010), além de remover o carbono orgânico do solo local de formação e deposição (van OOST et al., 2007).

Contudo, Dillenburg (2007) aborda que o uso de defensivos agrícolas, quando feito de forma excessiva, em conjunto com fortes precipitações pluviométricas, na forma de enxurradas, modificam a paisagem física dos riachos, causando poluição dos mesmos e suas respectivas degradações, através de processos erosivos, como observado no Rio Sanga Mineira (Mercedes/PR).

"Via de regra, as tipologias de uso/ocupação da terra reunidas pelos recursos agrossocio-econômicos, urbano-industrial e usos múltiplos dos recursos hídricos e ambientes hidromórficos, produzem alterações ambientais nas b.h's. Dentre os principais, registramos a expansão urbana desordenada, com concomitante crescimento desordenado dos núcleos populacionais; concentração de renda no campo e na cidade; emprego de técnicas agrossilvopastoris inadequadas; desmatamentos, queimadas, degradação pedológica; mineração clandestina; carcinicultura; ocupação de Áreas de Preservação Permanente; problemas oriundos do turismo e da agropecuária; poluição dos recursos hídricos e mudanças hidrológicas; aumento expropriador dos Complexos Agroindustriais e privatização das águas; problemas originários da industrialização e redução da biodiversidade etc" (NASCIMENTO, 2011). 
Tabela 9 - Ativades potencialmente poluidoras do Rio Mogi-Guaçu (MOTA, 1975; BRAILE \&

CAVALCANTE, 1979; CETESB, 1999 apud ESPÍNDOLA; BRIGANTE; ELER, 2003).

\begin{tabular}{|c|c|}
\hline Atividade & Potencial Poluidor Sobre A Água \\
\hline $\begin{array}{l}\text { Cultivo de batata, } \\
\text { morango, tomate, alho, } \\
\text { café e cana-de-açúcar }\end{array}$ & Pesticidas, corretivos do solo e fertilizantes \\
\hline $\begin{array}{ll}\text { Mineração } & \text { de } \\
\text { manganês } & \end{array}$ & Alta turbidez, elevados níveis de manganês e assoreamento \\
\hline Curtume & $\begin{array}{l}\text { Substâncias ricas em sulfato e metais pesados usados no tratamento do } \\
\text { couro; elevação do nível de sólidos em suspensão, alteração da } \\
\text { salinidade da água; DBO e DQO }\end{array}$ \\
\hline $\begin{array}{l}\text { Indústria/comércio de } \\
\text { produtos químicos }\end{array}$ & Ácidos; álcalis; sais tóxicos; fenois; nitratos de amônia; etc. \\
\hline $\begin{array}{l}\text { Usaína de açúcar e } \\
\text { álcool }\end{array}$ & Vinhaça (altos teores de potássio); cromo; rísco de poluição térmica \\
\hline $\begin{array}{l}\text { Fábrica de papel e } \\
\text { papelão }\end{array}$ & $\begin{array}{l}\text { Cola; caulím; composto orgânico mercurioso; fibras finas; pigmentos; alta } \\
\text { carga de suspensão; etc. }\end{array}$ \\
\hline Matadouros & $\begin{array}{l}\text { Alta DBO; sólidos em suspensão; graxas, altos teores de nitrogênio; } \\
\text { sangue; gordura; microorganismos patogênicos; etc. }\end{array}$ \\
\hline Frigoríficos & $\begin{array}{l}\text { Alta demanda de DBO; sólidos em suspensão; altos teores de nitrogênio; } \\
\text { sangue; gordura; microorganismos patogênicos; etc. }\end{array}$ \\
\hline Portos de areia & $\begin{array}{l}\text { Turbidez e assoreamento; emissão de material particulado; perda de solos } \\
\text { orgânicos; poluição das águas com óleo e graxas }\end{array}$ \\
\hline $\begin{array}{l}\text { Indústria de papel e } \\
\text { celulose }\end{array}$ & $\begin{array}{l}\text { Despejos sulfíticos (alta carga de matéria orgânica); elevado DBO e } \\
\text { sólidos em suspensão, caulim, etc. }\end{array}$ \\
\hline $\begin{array}{l}\text { Indústria de produtos } \\
\text { industriais }\end{array}$ & Polifosfatos; silicatos; carbonato de sódio; tetracloreto de carbono, etc. \\
\hline Metalúrgica & $\begin{array}{l}\text { Despejo ácido contendo cromo ou cobre, zinco, cádmio, níquel; despejos } \\
\text { alcalinos; contendo cianetos ou sulforetos, etc. }\end{array}$ \\
\hline Esgoto & Elevada DBO; coliformes; eutrofização \\
\hline $\begin{array}{l}\text { Indústria e comércio de } \\
\text { aguardentes }\end{array}$ & Vinhaça (altos teores de potássio); cromo; rísco de poluição térmica \\
\hline $\begin{array}{l}\text { Indústria de produtos } \\
\text { alimentícios }\end{array}$ & $\begin{array}{l}\text { Fecularia; alta DBO; ácido cianítrico; matéria nitrogenada; extração de } \\
\text { óleo vegetal; óleos; corantes; resinas, etc. }\end{array}$ \\
\hline Confinamento de gado & Elevada DBO; sólidos em suspensão; eutrofização \\
\hline Destilarias & $\begin{array}{l}\text { Sólidos sedimentáveis; açúcares; dextrina; proteínas; resínas; álcool } \\
\text { etílico; ácidos; ésteres; cetona; gorduras e bactérias }\end{array}$ \\
\hline
\end{tabular}

Com relação às atividades de turismo e lazer, o Rio Formoso (Bonito/MS) é um importante local para exploração do ecoturismo, onde Medina Júnior (2007) observou os vários impactos causados por esta atividade econômica que, segundo este autor, é uma atividade geradora de elevado impacto ambiental, a movimentação da água causada pelo pisoteio dos visitantes é evidente e os locais com menor rigor ambiental são os que mais sofrem as interferências sociais. 
Exemplo de problemas em locais de usos mistos, como na região de Sohan, no Egito, (atividades agrícolas, turístico, urbanização e recreação), o estudo feito por Ahmed \& Fawzi (2009) indicou que os impactos vigentes na citada localidade estão relacionados às alterações no próprio rio (obras de engenharia), gerando problemas diversos (erosão marginal, redução das áreas agricultáveis localizadas próximas às suas margens e redução de áreas ou mesmo desaparecimento de ilhas fluviais, influenciando na produção da agricultura).

Vale salientar que a circulação de pessoas causa danos diversos ao meio. A respeito disso, Magro \& Talora (2011) citaram a perda da vegetação e consequuente erosão do solo, presença do lixo, contaminação da água, incêndios e modificações do comportamento animal, bem como, impermeabilização do solo por conta do fluxo de pessoas e de animais (MARTINS, 1976), observado também no estudo feito por Albuquerque Sobrinho \& Meireles (2004) no Parque Ecológico da Lagoa da Maraponga, Fortaleza/CE.

As áreas definidas como naturais são aquelas que se apresentam com melhor condição biótica e abiótica do meio, embora quando se apresenta seccionada, como por exemplo, a construção de vias de circulação, torna-se mais sujeitas à degradação ambiental, dependendo da morfologia do terreno.

Outra atividade prejudicial é a exploração mineral e a implementação de obras civis, pois podem causar danos sócio-econômicos e ambientais.

Assim como a extração de minérios é impactante ao meio, como observado por López (2004), na extração de material particulado, tais como cascalhos e areias, cujo impacto causou o avanço gradual do rio Tuy (Venezuela).

O entorno destas obras, além de ser alterado por essas ações, pode ter a integridade física das mesmas comprometidas, segundo a dinâmica local, como no estudo feito por Ferreira (2011) sobre as interferências ambientais e legais entre as atividades de mineração e construção de gasodutos (tabela 10). 
Tabela 10 - Principais impáctos ambientais nos diferentes métodos de lavra que geram impáctos diretos nos ambientes fluviais (adaptado de FERREIRA, 2011).

\begin{tabular}{|c|l|l|}
\hline $\begin{array}{c}\text { Substância } \\
\text { mineral }\end{array}$ & \multicolumn{1}{|c|}{ Método de lavras } & \multicolumn{1}{|c|}{ Impáctos ambientais } \\
\hline Argila & Céu aberto, bancadas em flanco & $\begin{array}{l}\text { Alteração na topografia do terreno, } \\
\text { podendo induzir processos erosivos; } \\
\text { exposição do lençol freático; } \\
\text { Supressão de vegetação }\end{array}$ \\
\hline $\begin{array}{c}\text { Argila (várzea de } \\
\text { rios) }\end{array}$ & Céu aberto, em tiras & $\begin{array}{l}\text { Formação de cavas irregulares, com } \\
\text { exposição do lençol freático; } \\
\text { supressão de vegetação }\end{array}$ \\
\hline Areia & Céu aberto, dragagem em leito de rio & $\begin{array}{l}\text { Erosão nas margens do rio; } \\
\text { apronfundamento da calha, com } \\
\text { eventual exposição dos tubos e } \\
\text { assoreamento à jusante; supressão } \\
\text { de vegetação; instabilizando as } \\
\text { margens }\end{array}$ \\
\hline Água mineral & Céu aberto, captação de nascentes & $\begin{array}{l}\text { Modificações na geometria do leito do } \\
\text { curso d'água; supressão de } \\
\text { vegetação }\end{array}$ \\
\hline $\begin{array}{l}\text { A construção de gasoduto pode } \\
\text { impactar a fonte, alterando a sua } \\
\text { recarga e modificando a sua recarga } \\
\text { e modificando a qualidade da água }\end{array}$ \\
\hline
\end{tabular}

De acordo com o levantamento feito pelo PNUMA (2007) sobre os recursos hídricos superficiais do Brasil, os principais problemas que ocorrem nas bacias hidrográficas nacionais e em seus respectivos biomas, podem ser vistos na tabela 11.

O processo de industrialização tem influnciado na degradação ambiental, onde os impactos mais comumente observados, dizem respeito ao lançamento de efluentes industriais nos cursos d'água (FONTES, 2004; MARINS et al., 2004; OLIVEIRA et al., 2007). 
Tabela 11 - Problemas ambientais vigentes nas regiões hidrográficas brasileiras (PNUMA, 2007).

\begin{tabular}{|c|c|c|}
\hline RHBs & $\begin{array}{l}\text { Ecossistema / } \\
\text { Bioma }\end{array}$ & Problemas \\
\hline Amazônica & Amazônico & $\begin{array}{l}\text { Problemas de contaminação pontuais (Manaus e } \\
\text { Belém), vetores de doenças tropicais, contaminação } \\
\text { de igarapés, extração mineral, desmatamentos e } \\
\text { erosão dos solos. }\end{array}$ \\
\hline $\begin{array}{c}\text { Alto do Paraguai e } \\
\text { Pantanal }\end{array}$ & Pantaneiro & $\begin{array}{l}\text { Novas fronteiras agrícolas, poluição associada aos } \\
\text { centros urbanos, remoção de mata ciliar, pisoteio das } \\
\text { margens e modificação na dinâmica qualiquantitativa } \\
\text { das águas nos ecossistemas pantaneiros. }\end{array}$ \\
\hline $\begin{array}{c}\text { Cerrados do Brasil } \\
\text { Central }\end{array}$ & Cerrados & $\begin{array}{l}\text { Conflitos de uso da água para abastecimento público, } \\
\text { assoreamento e contaminação por produtos químicos, } \\
\text { remoção de mata ciliar, poluição de águas, ausencia } \\
\text { de tratamento de água, intensa modificação do Rio } \\
\text { Tocantis por conta dos sucessivos aproveitamentos } \\
\text { hidrelétricos. }\end{array}$ \\
\hline Semi-árido brasileiro & Caatinga e cerrado & $\begin{array}{l}\text { Limitações geoambientais ocasionando problemas } \\
\text { sócio-econômicos em escala local e regional } \\
\text { (nacional), incluindo a migração da população carente } \\
\text { para as metrópoles regionais e nacionais, degradação } \\
\text { do bioma caatinga, processo de desertificação, } \\
\text { salinização dos solos e recursos hídricos. }\end{array}$ \\
\hline $\begin{array}{c}\text { Litoral e zona da mata } \\
\text { nordestina }\end{array}$ & $\begin{array}{c}\text { Cerrado, Floresta } \\
\text { paludosa marítima }\end{array}$ & $\begin{array}{l}\text { Ocupação de áreas de riscos por população carente, } \\
\text { processo de favelização, poluição urbana, disposição } \\
\text { de resíduos sólidos, descarga industrial não tratada, } \\
\text { contaminação de mananciais, impermeabilização dos } \\
\text { solos, ausência de infra-estrutura sanitária. }\end{array}$ \\
\hline $\begin{array}{l}\text { Aglomerados urbanos e } \\
\text { regiões metropolitanas }\end{array}$ & $\begin{array}{c}\text { Mata atlântica, } \\
\text { Cerrado, Araucária } \\
\text { e Floresta paludosa } \\
\text { marítima }\end{array}$ & $\begin{array}{l}\text { Enchentes e estiagens, poluição urbana e industrial, } \\
\text { favelização, processo de urbanização equivocado, } \\
\text { problemas relacionados ao uso e ocupação do solo, } \\
\text { degradação ambiental, migração do campo para as } \\
\text { cidades, baixos níveis de tratamento dos esgotos } \\
\text { domésticos, disposição inadequada de resíduos } \\
\text { sólidos, impermeabilização do solo e problemas } \\
\text { derivados disto, comprometimento dos mananciais e } \\
\text { obstrução da rede de drenagens por lixo. }\end{array}$ \\
\hline $\begin{array}{l}\text { Zona costeira do sul e } \\
\text { sudeste }\end{array}$ & \begin{tabular}{|} 
Mata atlântica, \\
Cerrado, Araucária, \\
vegetação de \\
restinga e Floresta \\
paludosa marítima
\end{tabular} & $\begin{array}{l}\text { Deficiência de infra-estrutura sanitária, danos ao } \\
\text { ordenamento urbano, erosão marinha, áreas de } \\
\text { várzeas e planícies de inundação sujeitas à erosão } \\
\text { marinha, uso inadequada da zona costeira e alteração } \\
\text { da dinâmica costeira, inundações urbanas, } \\
\text { deficiências no abastecimento de água, coleta e } \\
\text { tratamento dos esgotos domésticos. }\end{array}$ \\
\hline
\end{tabular}

Legenda: RHBs = Regiões Hidrográficas Brasileiras. 
A grande diversidade de empresas existente nos municípios que compõem a Bacia do Rio Pardo, principalmente as que se encontram localizadas no Estado de São Paulo, faz com que ocorra uma grande variabilidade de contaminantes nos corpos de água (FONTES, 2004).

Segundo Marins et al. (2004) existem relatos de contaminação por metais pesados em várias regiões, como resultado das elevadas taxas de emissão por atividades industriais e urbanas concentradas nas bacias de drenagens e na região costeira desde a década de 80.

Estes efluentes, quando alcançam a zona costeira, através do lançamentos diretos nos cursos d'água, contaminam os diferentes ecossistemas aonde estes resíduos se propagam.

Uma das atividades sócio-econômicas realizadas no campo que mais degrada o ambiente, diz respeito às práticas agropecuárias, cujos impactos podem ser observados nas áreas próximas ou nos interiores das drenagens, caso do objeto de estudo desta tese.

A circulação de pessoas e de animais, como bois, cabras, dentre outros, pode provocar a degradação dos solos.

Segundo Talora (2007) os estudos relacionados ao pisoteio na vegetação têm indicado que a composição e frequência de espécies com diferentes formas de vida conferem diferentes graus de resistência e resiliência às comunidades, sendo que as características morfológicas das plantas determinam, na maioria das vezes, se estas plantas conseguem absorver bem o impacto com baixo nível de mudanças ou se as mesmas sofrem mudanças pós-impacto, ou até mesmo se recuperam em pouco tempo.

Já que os bovinos são mamíferos, que se apoiam e se movimentam sobre quatro membros, estando à parte distal dos mesmos revestidos por casco. A parte distal do membro anterior de um bovino é conhecida por mão e os seus dois dígitos são também designados por dedos, o dedo lateral e o dedo medial (didactilia). No membro posterior, a sua parte distal designa-se de pé, tendo estes também dois dedos, sendo lateral de maiores dimensões. Cada membro apresenta, além dos dois dedos principais, dois dedos suplementares ou rudimentares, encontrando-se estes 
últimos projectados atrás do boleto e geralmente não estão em contacto com o solo (SILVA, 2009).

É importante ressaltar que não apenas o pisoteio animal, mas também, o humano causa a degradação dos solos, induzindo aos problemas de erosão, em especial em áreas urbanizadas ou com fluxo constante de pessoas (ALBUQUERQUE SOBRINHO, 2001; ALBUQUERQUE SOBRINHO \& ANDRADE MEIRELES, 2004).

Embora isso ocorra, os diferentes tipos de animais causem impactos, a ponto de acarretar na erosão dos solos, é necessário definir a relação entre o tamanho da área e o número de indivíduos no seu interior.

Mesmo que em uma determinada área se possua um significativo número de animais, seus impactos podem ser minimizados com o confinamento destes, pois quando livres, a circulação dos mesmos criam trilhas, degrandando a cobertura vegetal do solo, que ao ficar exposto às intempéries, tornam-se susceptíveis à erosão, criando feições erosivas do tipo lineares, podendo evoluir até voçoroca e gerando assim, danos ao meio físico e biológico.

Quanto ao problema do uso e ocupação e o processo de degradação ambiental, Espindola et al. (2012) observaram que, no caso da modificação de áreas de florestas em outros usos, o uso da terra voltado para o plantio, no caso da porção do domínio morfoclimático do Amazonas, inserido na área que compõe o Estado do Mato Grosso, teve seu estado de degradação acentuado pelos grande latifúndios ao transformar áreas florestadas em pastagem, incluindo as áreas modificadas de florestas em plantio.

Este problema pode ocorrer, também, devido à circulação de pessoas no interior de áreas de lazer, como em parques ecológicos em áreas urbanas e desprovidos de gerenciamento ambiental (i.g. controle do número de visitantes e dos locais a serem utilizados), como observado por ALBUQUERQUE SOBRINHO \& MEIRELES (2004), embora esta questão ocorra também em áreas urbanas rurais sem planejamento adequado ou com problemas de gestão ambiental (PRAKASH, 2002; CANDIDO \& ZAINE, 2005).

Práticas conservacionistas podem amenizar o melhor as condições dos solos, cujos impactos tenham sido realizados por qualquer atividade sócio-econômica, 
embora, a ausência de tais práticas, bem como, o emprego de técnicas de preparo convencional, com passagem excessiva de maquinário agrícola sobre a superfície do solo ao longo do tempo pode pulverizar e decomposição da matéria orgânica, aumentando a susceptibilidade à erosão hídrica e eólica, transportando os agregados das frações mais finas dos solos durantes durante as tempestades de pó (BOTELHO \& GUERRA, 2003).

Haja vista o uso cauteloso do solo, algumas práticas podem melhorar ou mesmo minimizar os danos promovidos ao meio (MELLO; BUENO; PEREIRA, 2006), como se observa na tabela 12, onde ZOCCAL (2007) sugere algumas práticas no terreno, como também no próprio solo.

A impermeabilização do solo feita durante o processo construtivo, como criação de vias rurais e urbanas, por exemplo, é de grande importância, posto que tem como objetivo, aumentar a resistência mecânica do aterro que irá suportar a circulação de veículos. Tanto que o contato solo com pavimento facilita o processo erosivo em estradas, no entanto, o contato entre a superfície compactada com a menos compactada pode induzir a problemas erosivos, comumente observados ao longo das vias de circulação, especialmente nas áreas rurais.

O homem ao intervir na natureza, por meio de construções, estando elas tanto na planície fluvial e/ou fora dela, possibilita que problemas de natureza geotécnica e ambiental se materializem, degradando ainda mais o local.

Nesta complexidade de ações realizadas pelo homem, benfeitorias governamentais e privadas no terreno, dialogam contraditoriamente entre vantagens e desvantagens sócio-econômicas, como por exemplo:

- Galeria pluvial - Drenar as águas oriundas das chuvas, porém, quando mal planejadas, ou quando entrada vedada por sedimentos e/ou resíduos sólidos transportados pelo escoamento, ou vedada por despejo de lixo pela população, tem sua capacidade comprometida e contribui nos problemas de alagamentos nas áreas urbanizadas;

- Pontes e viadutos - Usadas para transpor obstáculos, estão sujeitas ao acúmulo de materiais geológicos diversos transportados pelas águas e correntes, fortemente sentido em áreas estuarinas, por conta do aporte de sedimento em circulação; 
Estradas - embora facilite a circulação entre pontos (localidades), o contato das vias, sejam elas de terra, asfaltadas ou em paralelepípedo, sujeitas à erosão, disponibilizando sedimentos, que são transportados pelas chuvas, podendo ocorrer a formações de feições erosivas, até atingir a forma de voçoroca. Quando esta circulação é feita por vias, como em estradas, rodovias e demais caminhos, tanto em áreas urbanas quanto rurais, induzem ao processo erosivo, onde as estradas rurais, carreadores, bem como o manejo inadequado de terraços e curvas de nível, têm impacto significativo no assoreamento de nascentes e córregos, já que servem de caminho para o escoamento superficial, dando início aos processos erosivos (GROSSI, 2006);

- Dutos - São importantes para facilitar o abastecimento (água, gás, óleo e outros produtos), ligações elétricas interadas (linhas de transmissão) etc., Apesar dos seus reconhecidos benefícios dessas infra-estruturas, os dutos estão sujeitos à erosão, explosão ou contaminação do solo e subsolo, em função do tipo de produto deteriorável usado;

- Piscinão - Uma boa opção para conter enchentes em áreas urbanas, porém, pode ser foco de mosquitos transmissores da dengue, dentres outros;

- Estruturas em solo (aterro) - Os aterros servem para cobrir porções superficiais dos solos que foram removidas, como na instalação de galerias pluviais e demais benfeitorias no subsolo, porém, podem estar sujeitas à erosão quando mal elaboradas durante o processo de construção;

- Muro de contenção - É uma das opções para se evitar a erosão ou ruptura de taludes, especialmente em encostas e nas áreas com fluxo de água, como em rios semi-canalizados. Contudo, o contato entre o concreto e o solo, pode ser uma zona de contato entre materiais com características diferentes, transformando-os em indutores ou aceleradores dos processos erosivos;

- $\quad$ Cortina atirantada - Vem sendo aplicada para segurar maciços rochosos com características geotécnicas desfavoráveis, quando apresentam fraturas preenchidas por argilas ou não, requerendo assim, a fixação dos mesmos, para se evitar a ruptura dos taludes rochosos. Contudo, dependendo da dinâmica hidrogeológica, a água subterrânea pode alterar o concreto, a ponto de rompê-lo, no caso da tensão 
no maciço for superior a capacidade de suporte da cortina, embora ocorra predominantemente em áreas urbanizados e ao longo das vias pavimentadas;

- Colunas de Jet grouting - Tem aplicação semelhante à cortina atirantada, embora seja usada em maciços terrosos, a fim de reforçá-los para não ocorrer à percolação de contaminantes, escavabilidade do maciço no caso de construções subterrâneas (ALBUQUERQUE SOBRINHO, 2006), podendo gerar recalques diferenciais durante o processo de jateamento, por conta da pressão usada na calda de cimento e na variação de volume no interior do solo. Sua aplicação em áreas fluviais pode ser feita em taludes sujeitos à erosão.

Quanto ao uso do solo pelo cultivo agrícola, este pode ser realizado nas mais diferentes porções do relevo que, dependendo de sua localização, pode gerar danos diversos devido ao processo de erosão e sedimentação. Esta questão está associada à inclinação do terreno, bem como, a natureza do material geológico e suas características geotécnicas (LORANDI et al., 2001), apesar do uso do solo, em função do tipo de interação sócio-econômica, pode degradar ainda mais o ambiente.

As áreas abauladas do terreno, quando alagadas, podem ser usadas para o cultivo, como por exemplo, de arroz (SANCHEZ et al., 1982), já que requerem uma significativa quantidade de água no seu cultivo. O impacto deste tipo de ação está relacionado à forma como é feito o uso do solo, disposição de sedimentos carreados ao interior do rio, bem como, alteração da qualidade da água, dependendo do tipo de ações corretivas ou melhoria do solo na planície de inundação. 
Tabela 12 - Práticas que podem ser utilizadas na melhoria do solo e minimização dos impactos causados ao solo (ZOCCAL, 2007).

\begin{tabular}{|c|c|}
\hline Práticas Edáficas & Práticas Mecânicas \\
\hline $\begin{array}{l}\text { Manutenção da cobertura vegetal; } \\
\text { Evitar e controlar as queimadas; } \\
\text { Evitar desmatamento das áreas impróprias } \\
\text { para exploração agrossilvopastoril; } \\
\text { Adequação das propriedades rurais quanto ao } \\
\text { uso e ocupação do solo; } \\
\text { Elaborar divisão correta das pastagens a fim de } \\
\text { evitar o pisoteio excessivo por parte dos animais; } \\
\text { Dividir o tamanho das pastagen, como também, } \\
\text { dos bebedouros e cochos à exploração pecuária } \\
\text { para evitar a formação de trilhos provocados } \\
\text { pelo caminhamento do rebanho. }\end{array}$ & $\begin{array}{l}\text { Elaboração de plantil em nível; } \\
\text { Subsolagem e áreas compactadas; } \\
\text { Cultivo mínimo das explorações; } \\
\text { Terraceamentos das áreas em riscos e sujeitas } \\
\text { ao escorrimento superficial das águas pluviais; } \\
\text { Adequação da localização, construção e } \\
\text { manutenção de infra-estruturas do tipo, reserve } \\
\text { canais de irrigação aos princípioatório, estradas, } \\
\text { carreadores, caminhos e canais de irrigação } \\
\text { direcionados aos princípios conservacionistas, e; } \\
\text { Efetuar a proteção das cabeceiras das } \\
\text { nascentes com as práticas mecânicas, } \\
\text { vegetativas e edáficas de conservação do solo e } \\
\text { água. }\end{array}$ \\
\hline
\end{tabular}

Ainda com relação à localização das diferentes culturas, Brigante et al. (2003) comentam que "Na bacia hidrográfica de montante, os processos de erosão e lixiviação são favorecidos não só por práticas agrícolas de uso do solo nos morros, as quais não adotam curvas de nível, mas também pela aração com implementos, praticada no sentido longitudinal da declividade do terreno, o que favorece a remoção de partículas de solo pelo vento e pela chuva, gerando as enxuradas que levam ao assoreamento dos manancias, e, consequentemente, reduzindo a capacidade de drenagem".

As culturas podem ser plantas, segundo a ciclicidade da plantação, tornando que alguns tipos possam ser plantados mais de uma vez ao ano, ao passo que outras, requerem cultivo mais fixo ao longo do tempo.

Pons (2006) apud Cereda Junior (2006) cita os diferentes tipos de cultivos, onde foram classificados como culturas perenes, o plantio de café e citrus; culturas anuais, como milho, soja, horticulturas e cana-de-açúcar.

Durante o período pós-colheita, relacionado ao cultivo da soja, por exemplo, quando o solo fica exposto, ausente de qualquer cobertura vegetal, propicia o 
surgimento de feições erosivas durante o período chuvoso, além disso ao se plantar este tipo de cultivo nas margens dos cursos d'água, favorecem o agravamento da degradação ambiental, pela ausência de vegetação ripária (SOUZA; GASPARETTO; NAKASHIMA, 2008).

Todas as variáveis aqui propostas fazem parte deste sistema de avaliação geoambiental em proposição, cujos valores adotados na classificação do estado de conservação do meio físico de um determinado curso, pode ser observado no capítulo 8.

\subsection{Propriedades pedológicas (físicas e morfológicas)}

Devido ao estudo feito na área, levando-se em consideração algumas variáveis comumente adotadas nos estudos pedológicos, decidiu-se em apresentar as propriedades físicas e morfológicas realizadas no locus de investigação.

Tal estudo tem como finalidade investigar o papel que as variáveis pedológicas tem na degradação dos solos existentes nas áreas correspondentes às margens do Córrego das Cruzes e o espaço tido como faixa marginal (o dado é teórico, pois a mesma foi praticamente degradada) e comparar os resultados obtidos com o Protocolo de Avaliação de Rápidos (EPA, 1987) e o sistema de avaliação aqui proposto.

A variável distribuição textural foi incluída no sistema de avaliação, localizado no tópico Parâmetros geotécnicos.

A caracterização da estrutura do solo é feita de acordo com a forma que os materiais estão estruturados nos diferentes horizontes (a - laminar, ba - prismática, $\mathrm{Ca}$ - colunar, cb - blocos subangulares, d - granular), como mostra a figura 9. 

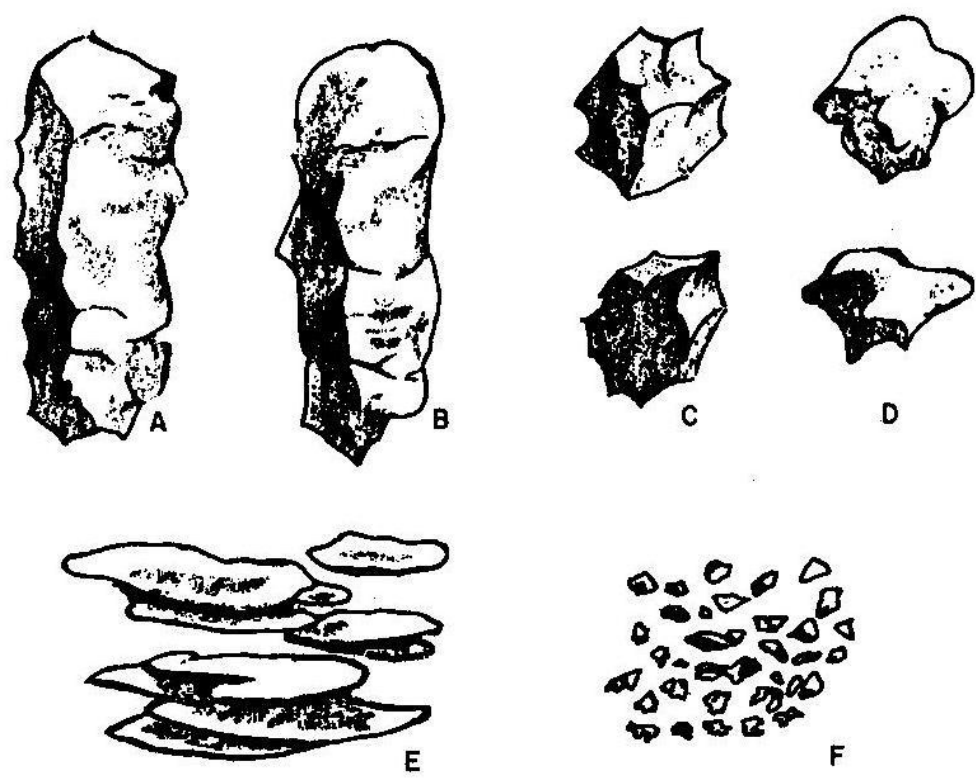

Figura 9 - Tipos de estruturas existentes nos diferentes horizontes dos solos (SBCS, 1982; VIERIA, 1988).

As informações pertinentes às propriedades físicas e morfológicas dos solos adotadas nas propriedades pedológicas e suas formas de avaliação, podem ser observadas na tabela 13. 
Tabela 13 - Propriedades físicas e morfológicas dos solos (adaptado de VIEIRA, 1988).

\begin{tabular}{|c|l|c|}
\hline Propriedades & \multicolumn{1}{|c|}{ Características } & Forma de Avaliação \\
\hline Distribuição & $\begin{array}{l}\text { Distribuição granulométrica dos materiais } \\
\text { geológicos. Esta propriedade serve, } \\
\text { também, para avaliação textural. }\end{array}$ & Granulometria \\
\hline Análise mecânica & $\begin{array}{l}\text { Avaliação do tamanho e da forma das } \\
\text { partículas que compõem os solos } \\
\text { (torrões,grumos, grânulos e concreções) } \\
\text { existentes em seu interior. }\end{array}$ & Táctil-visual \\
\hline Estrutura & $\begin{array}{l}\text { Corresponde a forma de agregação das } \\
\text { partículas dos solos (estrutura laminar, } \\
\text { prismática, em blocos e granular), onde } \\
\text { as mesmas apresentam dimensões } \\
\text { distintas. }\end{array}$ & \\
\hline Consistência & $\begin{array}{l}\text { Relaciona-se com as manifestações das } \\
\text { forças decoesão e de adesão que } \\
\text { atuamno solo, sob diferentes condições } \\
\text { de umidades (seca, úmida e molhada) }\end{array}$ & \\
\hline Textura & $\begin{array}{l}\text { A cor nos fornece informações quanto ao } \\
\text { conteúdo do material geológico, tais como } \\
\text { teor de ferro, teor de sílica e matéria } \\
\text { orgânica. }\end{array}$ & Táctil-visual \\
\hline Ver distribuição granulométrica & \\
\hline
\end{tabular}

Com relação ao tamanho das estruturas, as variações entre elas podem ser observadas na tabela 14, onde as mesmas foram agrupadas de acordo com a mesma classe de tamanho, embora varie entre elas, como por exemplo, a classe muito pequena para a estrutura laminar é considerada muito pequena, cujo tamanho seja inferior a $1 \mathrm{~mm}$, ao passo que a estrutura colunar é considerada muito pequena para tamanhos inferiores a $10 \mathrm{~mm}$. 
Tabela 14 - Variação entre os tamanhos das estruturas (adaptado de IBGE, 2007).

\begin{tabular}{|c|c|c|c|}
\hline \multirow{2}{*}{ Classes } & \multicolumn{3}{|c|}{ Tamanho (mm) } \\
\cline { 2 - 4 } & Laminar/Granular & Colunar/Prismática & $\begin{array}{c}\text { Blocos angulares/ } \\
\text { subangulares }\end{array}$ \\
\hline Muito pequena & $<1$ & $<10$ & $<5$ \\
\hline Pequena & $1-2$ & $10-20$ & $5-10$ \\
\hline Média & $2-5$ & $20-50$ & $10-20$ \\
\hline Grande & $5-10$ & $50-100$ & $20-50$ \\
\hline Muito grande & $\geq 10$ & $100-500$ & $\geq 50$ \\
\hline Extremamente grande & - & $\geq 500$ & - \\
\hline
\end{tabular}

Porosidade do solo: é a relação entre o volume de vazios e o volume total (SBCS, 1982 \& MACIEL FILHO, 1994). No entanto, sua determinação é feita a partir da análise do tamanho e sua quantidade, podendo ser granular ou grumosa.

Sua classificação quanto ao tamanho dos poros, é dividida em: muitos pequenos (1 a 2mm de diâmetro), pequenos (2 a $5 \mathrm{~mm}$ de diâmetro), médios (5 a 10 $\mathrm{mm}$ de diâmetro), grandes (>10 mm de diâmetro), sem poros (quando não observável por uma lupa de aumento de 10x).

A umidade do solo tem a capacidade de manter suas partículas unidas e também confere à capacidade que a cobertura vegetal tem em mantê-la por um período de tempo maior do que quando a cobertura está ausente (PINESE JUNIOR; CRUZ; RODRIGUES, 2008).

A infiltrabilidade é definida como sendo o fluxo de infiltração índice, que segundo LEl et al. (2006) determina a quantidade de água no perfil do solo e o runoff da superfície.

De acordo com Coelho Netto (2001) o termo infiltração foi proposto por Horton (1933) para designar a água que molha ou é absorvida pelo solo, enquanto, percolação, referia-se ao fluxo em subsuperfície que atravessa a zona de aeração em direção ao nível freático, o qual delimita a porção extrema superior da zona saturada do solo.

Coelho Netto (2001) comenta que o processo de infiltração resulta das relações de interdependência dos mecanismos de entrada na superfície do solo, de estocagem dentro do solo e de transmissão de umidade do solo. 
Martins (1977b) cita que a variabilidade da capacidade de infiltração se deve às variações em área geográfica e às variações no decorrer do tempo em uma área limitada (causada por ação animal, desmatamento, alteração das rochas superficiais; diferença de grau de umidade do solo, estágio de desenvolvimento vegetal, atividade de animais, temperatura; variações no decorrer da própria precipitação).

Para Guerra (2001), os fatores controladores das taxas de erosão são: a erosividade (causada pela chuva, sendo o total de chuva, sua intensidade, momento e a energia cinética da mesma correspondem aos parâmetros utilizados na investigação de erosividade); a erodibilidade (proporcionada pelas propriedades do solo, tais como a textura, densidade aparente, porosidade, teor de matéria orgânica, estabilidade dos agregados e $\mathrm{o} \mathrm{pH}$ do solos); as características das encostas (declividade, comprimento e no formato da encosta: concava e/ou convexa); e na natureza da cobertura vegetal (densidade da cobertura vegetal, tipo de cobertura vegetal e o percentual de cobertura vegetal são variáveis que influenciam no processo erosivo, quando relacionado ao papel da cobertura vegetal neste processo).

Quanto à capacidade de captação de água pelo solo retido, em um terreno previamente saturado, após sua drenagem natural por gravidade, SOUSA PINTO (1976) relacionou as diferentes texturas do solo e sua capacidade de campo, como observado na tabela 15.

Tabela 15 - Capacidade de campo para diferentes texturas do solo (adaptado de SOUSA

PINTO, 1976).

\begin{tabular}{|l|c|c|}
\hline \multicolumn{1}{|c|}{ Textura do solo } & Capacidade de campo (mm/m) & PMP (mm/m) \\
\hline Areia & 100 & 25 \\
\hline Areia fina & 115 & 30 \\
\hline Argilo-arenoso & 160 & 50 \\
\hline Argilo-siltoso & 280 & 115 \\
\hline Argila & 325 & 210 \\
\hline
\end{tabular}

Legenda: PMP = Ponto de Murchamento Permanente. 
As diferentes frações que compõem os materiais particulados dos solos apresentam propriedades distintas, de acordo com suas respectivas texturas (ver tabela 16).

Tabela 16 - Características das texturas dos materiais geológicos sob diferentes parâmetros geotécnicos (adaptados de Yoshizane, 2005).

\begin{tabular}{|c|c|c|c|c|}
\hline \multirow{2}{*}{ PROPRIEDADES } & ARENOSOS & SILTOSOS & ARGILOSOS & TURFOSOS \\
\cline { 2 - 5 } & Grossa (olho nu) & Fina (tato) & Muito Fina & Fibrosa \\
\hline Plasticidade & Nenhuma & Pouca & Grande & Média a Pouca \\
\hline $\begin{array}{c}\text { Compressibilidade } \\
\text { (carga estática) }\end{array}$ & Pouca & Média & Grande & Muito Grande \\
\hline $\begin{array}{c}\text { Compressibilidade } \\
\text { (carga vibrada) }\end{array}$ & Pouca & Média & Grande & Muito Grande \\
\hline Coesão & Nenhuma & Média & Grande & Pouca \\
\hline $\begin{array}{c}\text { Resistência ao } \\
\text { Solo Seco }\end{array}$ & Nenhuma & Média & Grande & Média a Pouca \\
\hline Resumo para \\
caracterização
\end{tabular}

\subsection{Sistemas de avaliação da qualidade dos ambientes fluviais}

A observação da dinâmica dos rios propiciou que muitos estudiosos classificassem tais ambientes, de acordo com as características distintas dos mesmos, tais como, nível de evolução geomorfológica dos rios - Ciclo de Davis; formato dos vales fluviais (THORNBURY, 1969); padrões das drenagens (LEOPOLD \& WOLMAN, 1957; SCHUMM, 1963; DURY, 1969; CHITALE, 1970 apud CHRISTOFOLETTI, 1981; CANT, 1982 apud NICHOLS, 1999), hierarquização de 
drenagem (STRAHLER, 1952 apud COELHO NETTO \& AVELAR, 2002) e pela disposição morfométrica (ROSGEN, 1994).

Este tipo de abordagem tem um forte apelo geomorfológico, a fim de avaliar e comparar as diferentes bacias/ drenagens, embora os índices usados sejam diversos e nem todos eles são contemplanos nesta caracterização.

O estudo feito por Jung, Niemann e Huang (2011) determinou as condições específicas para que as drenagens paralelas ocorram na natureza e a transição entre redes hidrográficas (dentríticas e paralelas) sejam elaboradas.

Outra técnica de caráter baseado na geomorfologia, relaciona-se com a Classificação de Rios Naturais, proposta por Rosgen (1994), que se baseia na compartimentação feitas por três níveis distintos: nível 1 - caracterização geomorfológica, nível 2 - descrição morfológica, nível 3 - nível de relação.

Sob o ponto de vista ecológico, diversos estudos propõem a classificação dos ambientes fluviais, aplicados não só à análise ambiental como também ao biomonitoramento.

Isto se deve ao fato de que as comunidades biológicas fornecem respostas integrais aos poluentes, como também, perturbação humana através da exposição contínua de magnitude, duração e frequência de estressores, constituindo-se assim como um importante avaliador da saúde ambiental (BARBOUR \& PAUL, 2010).

O TWINSPAN (Two-Way Indicator Species Analysis) é umas das técnicas adotadas na avaliação fluvial, à partir da classificação das formas vegetacionais, através de padrões de distribuição das espécies (HILL, 1979; KENT \& COCKER, 1992; apud MORENO \& CARDOSO, 2005; AVILA et al., 2011).

Segundo Moreno \& Cardoso (2005), este método é relativamente simples e utiliza apenas o número de indivíduos de espécies presentes por unidades amostrais escolhidas a partir de um critério de seleção, onde o resultado é a indicação de pseudo-espécies (classes de densidade das espécies encontradas nas unidades amostrais) preferenciais das unidades para a construção de uma tabela dicotômica (um grupo se divide em dois outros). Para isto, as amostras são classificadas pelas sucessivas divisões e, em seguida, as espécies são classificadas da mesma maneira, usando como base nas amostras, gerando ao final, agrupamentos 
vegetacionais compostos por uma flora característica determinante de uma dada região.

Moreno \& Cardoso (2005) comentam que a disposição de unidades amostrais, na forma de parcelas, em zonas de transição é importante na utilização no TWINSPAN para obtenção de grupos que indiquem a localização da delimitação de formas vegetacionais.

Staniszewski et al. (2006) estudaram vários rios da Polônia, onde os mesmos utilizaram, além do RIVPACS, macrófitas como bioindicadores da qualidade da água, em que o seu emprego contribuiu para uma melhor avaliação da qualidade dos ambientes fluviais, ao passo que Aroviita et al. (2008) utilizaram macroinvertebrados bentônicos para avaliar o estado da fauna de rios impactados, na porção ocidental da Finlândia.

Outros exemplos de avaliação pautada no aspecto biológico podem ser feitos pelos sistemas de classificação de rios: River Habitat Survey (incluindo derivação dos índices de pontuação para Modificação de Habitat e Avaliação da Qualidade do Habitat), incluindo o Índice de Funcionamento Fluvial, Index de Faixa de Buffer e Índice de Estado Selvagem, este reconhece que os elementos hidromorfológicos, junto com os elementos químicos, suportam a qualidade dos elementos biológicos na definição do estado ecológico, especialmente: o regime hidrologico (quantidade e dinâmica do fluxo, a ligação a massas de águas subterrâneas); continuidade do rio e condições morfológicas, tais como os padrões do canal, variação de largura e profundidade, velocidade do fluxo, condições do substrato e condição de zona ripária.

A União Europeia financiou vários projetos de pesquisa, com intuito de desenvolver sistemas de avaliações ecológicas que preencham os requisitos da Water Framework Directive (BARBOUR \& PAUL, 2010). Sendo que a AQEM foi um desses projetos, o qual é um sistema de avaliação para rios europeus, baseado em macroinvertebrados. Neste sistema, os principais elementos são: procedimento de amostragem harmonizadas; um banco de dados das características ecológicas de macroinvertebrados bentônicos europeus usados para todos os cálculos de métricos; metodologia para calcular as avaliações métricas; e procedimentos 
multimétricos, que foram definido individualmente para cada um dos tipos de rio estudado (HERING et al., 2004; BALESTRINI; CAZZOLA; BUFFAGNI, 2004).

O Urban River Survey (URS) é uma adaptação do River Habitat Survey (RHS), que foi desenvolvido para atender às características geomorfológicas e composições ecológicas de canal, como também, a zona ripária circundante em áreas urbanas (DAVENPORT; GURNELL; ARMITAGE, 2004).

Braioni et al. (1994) apud Braioni et al. (2001) desenvolveram três Índices de Avaliações Ambientais para Qualidade da Margem de Rio. O Índice de Estado Selvagem reflete o estado de conservação da natureza na margem e a potencialidade da área para suportar um alto nível de biodiversidade. O Índice faixa tampão provem medição indireta da capacidadede filtrar, metabolizar e bioacumular nutrientes e poluentes da zona riparia. Já o Índice de Paisagem Ambiental leva em conta a história social e os impactos das ticidades humanas, ao mesmo tempo o estado e função das comunidades biológicas de as áreas levantadas e o território circundante.

Outras vezes, combinações de informações relacionadas ao meio físico, aspectos biológicos e análise químicas são agrupadas, como no caso do (EPA, 1987).

DIRECTIVE (2000) apud Staniszewski et al. (2006) comenta que o Comitê Europeu de Proteção às Águas (fluviais, transicionais, costeiras e subterrâneas) formaliza a necessidade de se padronizar, comparar e difundir dados sobre os ecosistemas aquáticos europeus, através da Water Framework Directive.

Wyrick \& Klingeman (2010) propuseram uma ferramenta para melhorar as classificações de rios e projetos de restauração.

Já o sistema de classificação elaborado por Thomson, Taylor e Brierley (2004) integra os aspectos físicos (dentro e entre as classes geomorfológicas) e biológicos (similaridade das comunidades de macroinvertebrados) da forma lóticos e reforçaria a conservação e esforços de restauração, permitindo comparações mais significativas entre os locais e melhoraria na compreensão funcional destes ecossistemas. 
Outra abordagem ambiental é feita pela caracterização geoquímica da águas e sedimentos dos corpos hídricos, onde elementos ecotoxicológicos são levantados (ZUFFO, 1998; GROSSI, 2006; ZANINI, 2009).

O Índice de Qualidade de Água é um das ferramentas que emprega parâmetros fisico-químicos no diagnóstico da qualidade da água no Estado de São Paulo e seus objetivos (abastecimento público, proteção da vida aquática e balneabilidade da vida aquática), embora cada finalidade apresente um subconjunto de índices (CRH, 2006).

Este tipo de avaliação é muito corrente, tanto no Brasil (ZUFFO, 1998; BRIGANTE et al., 2003; VENDRAMINI, 2009) quanto no exterior (OUDIN; MEYBECK; ROUSSEL, 1999; KANNEL et al., 2007; FULAZZAKY; SEONG; MASIRIN, 2010), ocorrendo, outrossim, variações no conteúdo paramétricos e limitações que variam de acordo com o tipo de uso.

No caso do Brasil, a CETESB adaptou e desenvolveu o Índice de Qualidade das Águas (IQA), através do uso de 9 parâmetros (temperatura da amostra, pH, oxigênio dissolvido, demanda bioquímica de oxigênio, coliformes termotolerantes, nitrogênio total, fósforo total, resíduo total e turbidez) utilizados para avaliar a qualidade das águas, com foco principal nas águas usadas para o abastecimento público (CRH, 2006; CETESB , 2011).

O Stream Water Quality Model (QUAL2) e suas variações QUAL2E (BROWN \& BARNWELL, 1987; RAUCH et al., 1998; SHANAHAN et al., 1998; SEOK \& LEE, 2002; NAHON; KISHI; FERNANDES, 2009; BIRGAND, 2011e QUAL2K (BROWN \& BARNWELL, 1987; EPA, 2011), são exemplos de abordagem fisico-química das águas fluviais.

Estes modelos são usados na avaliação das medidas de gestão da qualidade da água, embora a avaliação da qualidade das águas dos rios, vem sendo constantemente refinada e atualizada a fim de atender aos novos e problemas emergentes de poluição das águas superfíciais, como o da eutrofização e toxicidade aguda e crônica, etc. (RAUCH et al., 1998).

No entanto, o QUAL2E emprega mais de uma centena de parâmetros, resultando na incerteza do modelo, já que a incerteza dos parâmetros pode comprometer toda a confiança nos resultados (BIRGAND, 2011). Além disso, a 
probabailidade de parâmetro pode ser apresentada em até 15 variáveis de estado. Devido ao aspecto espacial da modelagem, a incerteza de um determinado parâmetro não necessariamente tem o mesmo efeito na variância de um estado variável ao longo de um corpo fluvial modelado.

SILVINO (2008) comenta que o programa QUAL2K considera a vazão constante em cada elemento computacional, calculando a vazão de saída a partir do somatório das vazões pontuais e difusas que entram, e da subtração das pontuais e difusas que são retiradas. Além disso o programa utiliza essas vazões modeladas para simular a variação espacial das variáveis físicas, químicas e biológicas de qualidade da água, assim como os coeficientes de reaeração (K2), transformando esta ferramenta de cunho avaliativo, no QUAL2Kw, omo sendo uma versão mais moderna do QUAL2K (PELLETIER; CHAPRA; TAO, 2006; SILVINO, 2008; CHO \& HÁ, 2010).

O modelo QUAL2Kw utiliza as seguintes variáveis: temperatura, condutividade elétrica, sólidos inorgânicos em suspensão, oxigênio dissolvido, demanda bioquímica de oxigênio carbonácea de reação lenta e de reação rápida, nitrogênio orgânico, nitrato de nitrogênio, fósforo inorgânico, fitoplancto, detrito, patógeno, alcalinidade, carbono inorgânico total, biomassa de alga de fundo, nitrogênio de alga de fundo e fósforo de alga de fundo (PELLETIER; CHAPRA; TAO, 2006).

\subsubsection{The River Styles Framework (NSW \& DLWC)}

Desenvolvido como ferramenta de pesquisa por geomorfologistas em parceria entre New South Wales Department of Land e Water Conservation, o sistema The River Styles Framework (NSW \& DLWC) vem sendo empregado no gerenciamento de rios (BRIERLEY et al., 2002).

De acordo com Land \& Water, Austrália (2011) o River Styles fornece um modelo biofísico para gerenciamento de rios, que é diretamente apropriado à estrutura e função dos rios da Austrália, proporcionando uma avaliação geomorfológica da linha de base do caráter do rio, condição e comportamento. O formulário de conexões procedimentais e processuais dentro de uma unidade 
geomórfica e avaliação da evolução fluvial fornecem um modelo biofísico para benchmarking integrativo e programas de biomonitoramento e gestão de tomada de decisão.

Esta avaliação se baseia na caracterização das condições geomorfológicas da drenagem, tais como geometria do canal, agrupamento de unidades geomorfológicas, distinção de um conjunto de atributos e cálculo em termos da plataforma do canal (BRIERLEY AND FRYIRS, 2000 apud THOMSON; TAYLOR; BRIERLEY, 2004).

Fryirs (2003) comenta que os procedimentos necessários para a adoção deste sistema consistem em três passos distintos: 1) identificação do tipo de rio, denominado de River Style, como também, sua capacidade de ajuste no interior do próprio vale; 2) avaliação evolutiva do rio como base para identificação de mudanças gemorfológicas irreversíveis e uma condição de referência "natural"; e, 3) determinar e explicar a condição geomórfica de cada desembocadura em uma bacia hidrográfica. Aplicação do procedimento é demonstrado para entrada de um aluvião e o Estilo do Rio (River Style) confinado na captação de Bega, na costa sul de Nova Gales do Sul, Australia, como denota a figura 10.

Contudo, Thomson, Taylor e Brierley (2004) levaram em consideração o aspecto biológico através do uso da assembleia de macroinvertebrados e características do habitat de lago e unidades geomorfológicas e uma série de unidades geomorfológicas de três diferentes rios na costa norte da New South Wales, Austrália. 


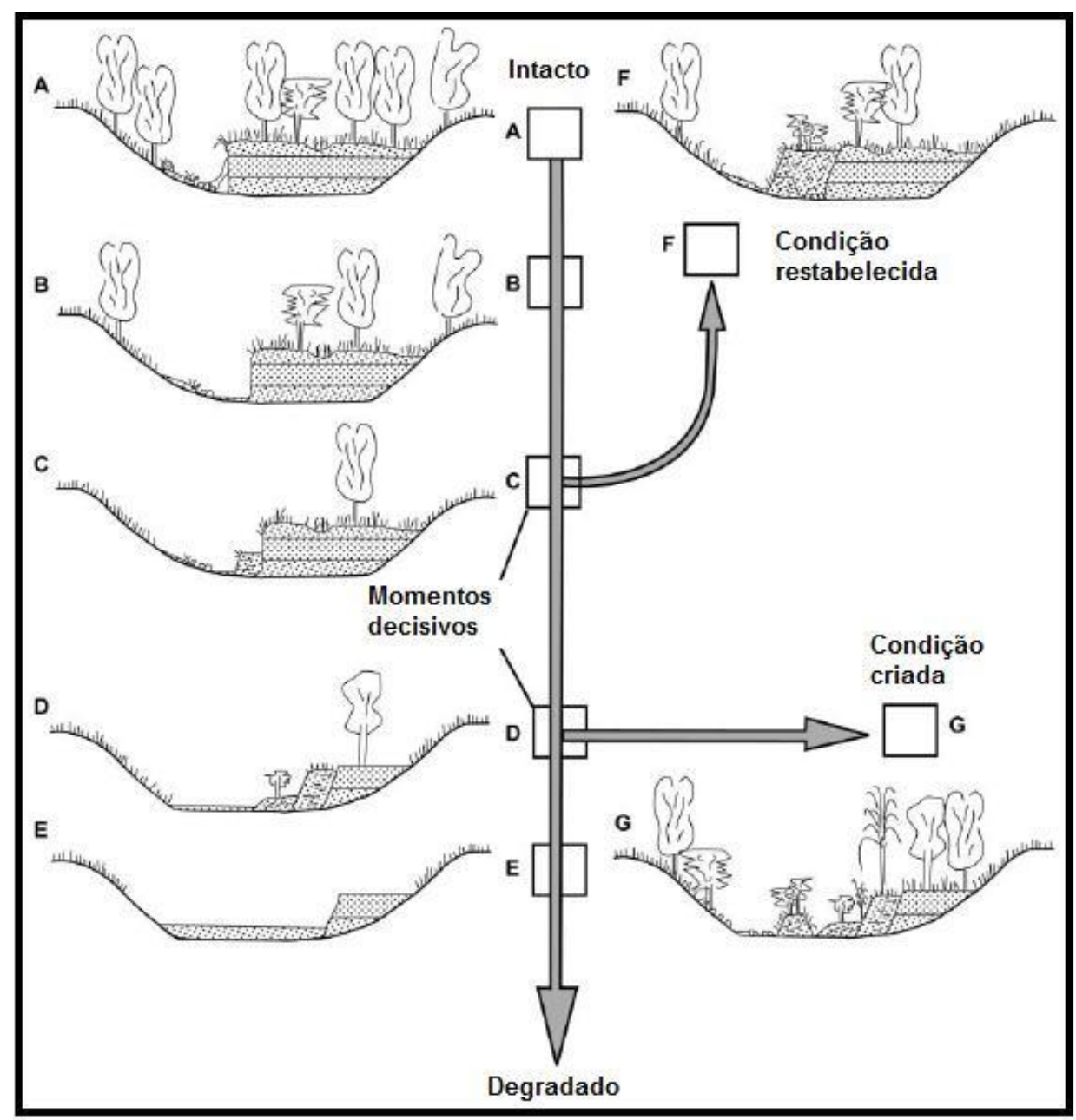

Figura 10 - Aplicação do potencial de recuperação do framework para vale parcialmente confinado com leito rochoso com descontinuidade controlada do River Style da planície de inundação (BRIERLEY et al., 2002).

\subsubsection{Análise Morfométrica dos Ambientes Fluviais}

O estudo sobre a forma e a influência que os fatores geomorfológicos influenciam na evolução dos cursos d'água, podem ser realizados através da análise morfométrica destes ambientes, tanto na escala de bacia quanto na de drenagem.

Estes parâmetros que compõem a análise morfométrica são de suma importância nas investigações sobre os processos internos que ocorrem nos reservatórios, por exemplo, como comentado por Tundisi (1988), que segundo o citado autor, no caso dos reservatórios construídos, sua localização, orientação em 
relação à direção dos ventos preferenciais, a morfologia da área a ser inundada, são de extrema importância, já que estas características determinam, em parte, a amplitude de atuação das forças sobre esses ecossistemas artificiais.

No entanto, os parâmetros morfométricos comumente empregados são: área, perímetro, comprimento da drenagem dos canais, densidade de drenagem, frequencia de drenagem, taxa de bifurcação, taxa de textura, taxa circulatória, constância de manutenção do canal, índice de contribuição do canal, índice de força fluvial (CHRISTOFOLETTI, 1980; Dalla FONTANA \& MARCHI, 2003 apud MARCHI \& Dalla FONTANA, 2005; PANKAJ \& KUMAR, 2009).

O papel da atividade tectônica nos estudos geomorfológicos, em especial nos ambientes fluviais, passou a ser considerado no início da década de oitenta do século XX, a partir de áreas tectonicamente instáveis (OLLIER, 1981; SUMMERFIELD, 1987; SUMMERFIELD, 1991 apud ALVES \& CASTRO, 2003; VERRIOS, ZYGOURI, KIKKALAS, 2004), em decorrência do papel que as forças internas exercem sobre os vales fluviais (CHRISTOFOLETTI, 1980).

Neste sentido, Verrios, Zygouri, Kikkalas (2004) analisaram o papel que a morfotectônica exerce sobre a zona de falha Eliki, no golfo de Corinto, Grécia, no referido estudo, os citados autores comentam que a combinação de dados morfométricos em conjunto com dados sísmicos e geomórficos parecem ser ferramentas importantes na determinação relativa do nível de atividade tectônica e fornece dados para avaliação de riscos sísmicos, incluindo ainda, a parcepção de que a atividade tectônica nesta porção grega está diminuindo ao longo do tempo.

A questão tectônica, a despeito de sua importância no que se refere à capacidade de modificação geoambiental dos cursos fluviais, a mesma não foi incluída neste sistema de avaliação por não ser predominante no território brasileiro, embora atividade sísmica e tectônica ocorra em alguns locais da placa tectônica sulamericana.

Como o tectonismo está correlacionado ao controle geológico local, Alves \& Castro (2003) afirma que os parâmetros morfométricos relacionados a tais questões são: relação de relevo (Rr), densidade hidrográfica (Dh), gradiente de canais (Gc), índice de circularidade (Ic) e índice de sinuosidade (Is). 
Destas variáveis, foram levantadas a relação de relevo, densidade hidrográfica, gradiente de canais e índice de sinuosidade, para a área de estudo, cujos dados são apresentados no tópico 7.6 .

Segundo Zancope (2004), a determinação do grau de sinuosidade de um canal fluvial corresponde ao quociente do comprimento do canal pelo comprimento do vale no mesmo trecho, como observado na fórmula 2):

$$
\text { Is }=\mathrm{Cv} / \mathrm{Cc}
$$

onde: Is é o índice de sinuosidade; $C c$ é o comprimento do canal em determinado trecho, e; $C v$ é o comprimento do vale no mesmo trecho, medido ao longo da linha situada na metade da largura da planície fluvial, isto é, na distância média entre os sopés das vertentes.

De acordo com Lana, Alves e Castro (2001), os valores obtidos quando próximos a 1,0 indicam que o canal tende a ser retilíneo, ao passo que os de valores superiores a 2,0 sugerem canais tortuosos e os valores intermediários indicam formas transicionais, regulares e irregulares.

Os citados autores, no mesmo estudo, comentam que a sinuosidade dos canais é influenciada pela carga de sedimentos, pela compartimentação litológica, estruturação geológica e pela declividade dos canais.

O número de ordem total foi proposto, incialmente por Horton (1945), porém foi modificado por Strahler (1952) apud Christofoletti (1980), sendo um dos parâmetros mais usados para a hierarquia fluvial, pois determina o número de cursos d'água que compõe a bacia hidrográfica, onde as áreas de nascentes seriam classificadas como sendo de primeira ordem, onde a confluência dos canais de primeira ordem com uma segunda ordem criaria uma segunda ordem e assim por diante.

O comprimento total do rio é baseado na medição direta ou indireta do mesmo, onde normalmente o valor apresentado é expresso em quilômetro $(\mathrm{km})$.

Aguiar (2009) explica que as variáveis relacionadas às grandezas bidimensionais ou de dados provenientes de medições topográficas, além de medições lineares da rede e da bacia de capacitação, cujos procedimentos podem ser feitos por softwares de CAD e expresso em $\mathrm{km}^{2}$, no caso da medição de áreas. 
A taxa de bifurcação corresponde a relação entre o número total de segmentos de uma certa ordem $\left(\mathrm{N}_{\mathrm{u}}\right)$ e o número total dos de ordem imediatamente superior $\left(\mathrm{N}_{\mathrm{u}+1}\right)$, como definido por Horton (1945) apud Christofoletti (1980).

Christofoletti (1980) afirma que o valor referente à taxa de bifurcação nunca pode ser inferior a 2, e não se deve levar em consideração às feições canalizadas causadas pelo escoamento pluvial.

A frequência de drenagem ( $\mathrm{Fs}$ ) ou densidade de rios, pode ser compreendida como sendo a relação entre a quantidade de drenagem $\left(\Sigma^{\mathrm{Nu}}\right)$ de uma determinada bacia pelo seu respectivo tamanho, onde o mesmo foi proposto por Horton (1945) apud Christofoletti (1980).

A definição da relação entre o aporte de sedimentos por unidade de área pode ser feita através do uso da quantificação da relação de relevo, cuja variável foi proposta por Schumm (1956) apud Aguiar (2009), sendo atribuida pela amplitude altimétrica máxima pelo comprimento total da bacia. Neste sentido, Aguiar (2009) comenta que quanto maior for o valor da relação de relevo, maior será a velocidade de escoamento e menor taxa de infiltração.

No entanto, Christofoletti (1980) reintera que este parâmetro é importante na análise das bacias hidrográficas, pois apresenta relação inversa com o comprimento dos corpos fluviais, já que a medida que aumenta, numericamente, a densidade hidrográfica, diminui o tamanho dos componentes fluviais das bacias de drenagem.

Pires Neto (1991) apud Fontes (2004) defende que a densidade de drenagem cujo valor é elevado, indica um baixo índice de infiltração, resultando em uma rápida concentração do escoamento superficial e alto potencial de fluxo. Por outro lado, áreas de baixa densidade apresentam elevado índice de infiltração e escoamento laminar generalizado, apesar de variáveis do meio físico, como a geologia, topografia, clima, vegetação e número de ciclos de erosão (FONTES, 2004).

As aplicações de abordagens geomorfológicas, a partir de dados morfométricos já são bem conhecidas, como no trabalho de Demattê \& Demétrio (1995) relacionando os padrões de drenagem de bacias hidrográficas na caracterização de solos no Estado do Paraná.

Exemplo disso, deu-se por meio do estudo feito por Alves \& Castro (2003) para a bacia do Rio do Tanque (afluente da margem esquerda do rio Santo Antônio, 
médio vale do rio Doce, Estado de Minas Gerais), onde as falhas geológicas de direção NW-SE controlam a maior parte dos canais da rede de drenagem, os quais ocorrem geralmente encaixados, e os de direção NE-SW, além de controlarem uma pequena parte dos canais, sendo os principais responsáveis pelos barramentos da citada bacia, condicionando a presença de níveis de base locais ocasionando a retenção de sedimentos e consequente meandramento dos canais.

Aguiar (2009) comparou duas bacias no Estado do Paraná (Iguatemi e Piquiri) através de uma abordagem hidrogeomorfológica e hidrossedimentológica, comparando dados, também, de fontes morfométrica e sensoreamento remoto por satélite.

As fórmulas usadas para calcular os diferentes parâmetros, seguidos da definição dos mesmos, são apresentadas na tabela 17 e 18.

Como foi possível observar através das tabelas 17 e 18, existe uma variedade de parâmetros morfométricos, os quais nem todos são usados em um mesmo estudo, com feito por Christofoletti (1980); Demattê \& Demétrio (1995); Dalla Fontana \& Marchi (2003) apud Marchi \& Dalla Fontana (2005); Lugão; Calijuri; Loures (2009); Pankaj \& Kumar (2009), em decorrência do objetivo e/ou mesmo facilidade de acesso a informação. 
Tabela 17 - Descrição dos parâmetros morfométricos e suas fórmulas (SHERMAN, 1932; HORTON, 1945; STRAHLER, 1964; MELTON; 1957; VERSTAPPEN, 1983; PATTON, 1988; RITTER et al., 1995; BISWAS et al., 1999; MACKA, 2001; REDDY et al., 2004 apud OZDEMIR \& BIRD, 2009).

\begin{tabular}{|c|c|c|}
\hline $\begin{array}{l}\text { Parâmetros } \\
\text { morfométricos }\end{array}$ & Fórmulas & Descrição \\
\hline $\begin{array}{l}\text { Razão textural } \\
\qquad(\mathrm{T})\end{array}$ & $T=N_{D 1}(1 / P)$ & $\begin{array}{l}\text { Razão entre rio de primeira ordem e o perímetro da } \\
\text { bacia }\end{array}$ \\
\hline $\begin{array}{l}\text { Relevo da bacia } \\
\text { (Bh) }\end{array}$ & $\mathrm{Bh}=\mathrm{H}_{\max }-\mathrm{H}_{\min }$ & $\begin{array}{l}\text { Distância vertical máxima entre os pontos mais } \\
\text { baixos e mais altos da sub-bacia. }\end{array}$ \\
\hline $\begin{array}{l}\text { Número robustez } \\
\qquad(\mathrm{Rn})\end{array}$ & $R_{n}=B_{h}-D_{d}$ & $\begin{array}{l}\text { O produto do relevo da bacia e a densidade da } \\
\text { drenagem }\end{array}$ \\
\hline $\begin{array}{l}\text { Densidade de } \\
\text { drenagem } \\
\text { (Dd) }\end{array}$ & $\begin{array}{l}\qquad \mathrm{Dd}=\Sigma \mathrm{L} / \mathrm{A} \\
\mathrm{C} \text { - comprimento total } \\
\text { dos canais } \\
\text { A - área total da bacia }\end{array}$ & $\begin{array}{l}\text { Esta variável se relaciona diretamente com os } \\
\text { processos climáticos atuantes na área estudada, os } \\
\text { quais influenciam o fornecimento e transporte de } \\
\text { material detrítico ou indicam o grau de manipulação } \\
\text { antrópica }\end{array}$ \\
\hline $\begin{array}{l}\text { Coeficiente de } \\
\text { manutenção } \\
(\mathrm{Cm})\end{array}$ & $\begin{array}{c}\mathrm{Cm}=\frac{1}{\mathrm{Dd}} 1000 \\
\mathrm{Dd}-\text { densidade de } \\
\text { drenagem }\end{array}$ & $\begin{array}{l}\text { Fornece a área mínima necessária para a } \\
\text { manutenção de um metro de canal de escoamento }\end{array}$ \\
\hline $\begin{array}{l}\text { Índice de } \\
\text { rugosidade (Ir) }\end{array}$ & $\begin{array}{c}\mathrm{Ir}=\mathrm{H}^{*} \mathrm{Dd} \\
\mathrm{H}-\text { amplitude } \\
\text { altimétrica } \\
\text { Dd - densidade de } \\
\text { drenagem }\end{array}$ & $\begin{array}{l}\text { Combina dados altimétricos com a densidade de } \\
\text { drenagem }\end{array}$ \\
\hline $\begin{array}{l}\text { Fator de Forma } \\
\qquad(\mathrm{Kf})\end{array}$ & $K f=A / L$ & $\begin{array}{l}\text { É a relação entre aárea da bacia }(A) \text { pela extensão } \\
\text { do curso d'água mais longo }(L)\end{array}$ \\
\hline $\begin{array}{l}\text { Relação de Relevo } \\
\qquad(\mathrm{Rr})\end{array}$ & $\begin{array}{l}\qquad \mathrm{Rr}=\frac{\Delta \mathrm{a}}{\mathrm{L}} \\
\mathrm{D} \text { a - amplitude altimétrica } \\
\mathrm{L} \text { - comprimento do canal } \\
\text { principal }\end{array}$ & $\begin{array}{l}\text { Estabelece a relação entre a diferença entre a altitude } \\
\text { máxima e a mínima na bacia com o comprimento total do } \\
\text { canal principal }\end{array}$ \\
\hline $\begin{array}{c}\text { Densidade } \\
\text { hidrográfica (Dh) }\end{array}$ & $\begin{array}{c}\mathrm{Dh}=\frac{\mathrm{n}}{\mathrm{A}} \\
\mathrm{n} \text { - número de canais } \\
\mathrm{A} \text { - área total da bacia }\end{array}$ & $\begin{array}{l}\text { Expressa o número de canais existentes em cada } \mathrm{km}^{2} \text { da } \\
\text { bacia hidrográfica, indicando o potencial hídrico da região }\end{array}$ \\
\hline
\end{tabular}


Tabela 18 - Continuação da descrição dos parâmetros morfométricos (SHERMAN, 1932; HORTON, 1945; STRAHLER, 1964; MELTON; 1957; VERSTAPPEN, 1983; PATTON, 1988; RITTER et al., 1995; BISWAS et al., 1999; MACKA, 2001; REDDY et al., 2004 apud OZDEMIR \& BIRD, 2009).

\begin{tabular}{|c|c|c|}
\hline $\begin{array}{l}\text { Parâmetros } \\
\text { morfométricos }\end{array}$ & Fórmulas & Descrição \\
\hline $\begin{array}{l}\text { Gradiente de } \\
\text { canais (Gc) }\end{array}$ & $\begin{array}{l}\text { Gc = amax / L (\%) } \\
\text { amax - altitude máxima } \\
\text { L - comprimento do } \\
\text { canal principal }\end{array}$ & $\begin{array}{l}\text { Relação entre a cota máxima e o comprimento do } \\
\text { canal principal expresso em porcentagem. A sua } \\
\text { finalidade é indicar a declividade dos cursos d'água }\end{array}$ \\
\hline $\begin{array}{l}\text { Índice de } \\
\text { circularidade } \\
\text { (Ic) }\end{array}$ & $\begin{array}{l}\qquad \mathrm{Ic}=\frac{\mathrm{A}}{\mathrm{Ac}} \\
\mathrm{A} \text { - área total da bacia } \\
\text { Ac - área do círculo de } \\
\text { perímetro igual ao da } \\
\text { área total da bacia }\end{array}$ & $\begin{array}{l}\text { Ic }=0,51 \text { - escoamento moderado e pequena } \\
\text { probabilidade de cheias } \\
\text { Rápidas; Ic > 0,51- bacia circular favorecendo os } \\
\text { processos de inundação (cheias rápidas); lc }<0,51 \text { - } \\
\text { bacia mais alongada favorecendo o escoamento }\end{array}$ \\
\hline $\begin{array}{l}\text { Índice de } \\
\text { sinuosidade } \\
\text { (Is) }\end{array}$ & $\begin{array}{l}\qquad \mathrm{Is}=\frac{\mathrm{L}}{\mathrm{dv}} \\
\mathrm{L} \text { - comprimento do } \\
\text { canal principal } \\
\mathrm{dv} \text { - distância vetorial } \\
\text { entre os pontos } \\
\text { extremos do canal } \\
\text { principal }\end{array}$ & $\begin{array}{l}\text { Is } 1,0 \text { - o canal tende a ser retilíneo; Is > 2,0 - } \\
\text { canais tortuosos Valores intermediários indicam } \\
\text { formas transicionais, regulares e irregulares. A } \\
\text { sinuosidade dos canais é influenciada pela carga } \\
\text { de sedimentos, pela compartimentação litológica, } \\
\text { estruturação geológica e pela declividade dos } \\
\text { canais }\end{array}$ \\
\hline $\begin{array}{l}\text { № de ordem total } \\
\qquad\left(\Sigma^{\mathrm{Nu}}\right)\end{array}$ & $\left(\Sigma^{\mathrm{Nu}}\right)$ & № de ordem total da bacia \\
\hline $\begin{array}{l}\text { Comprimento total } \\
\qquad\left(\Sigma^{\mathrm{L}}\right)\end{array}$ & $\left(\Sigma^{\mathrm{L}}\right)$ & Comprimento de cada ordem no nível de sub-bacia \\
\hline $\begin{array}{l}\text { Taxa de bifurcação } \\
(\mathrm{Rb})\end{array}$ & $\mathrm{Rb}=\mathrm{Nu} / \mathrm{Nu}+1$ & $\begin{array}{l}\text { Razão entre } \mathrm{n}^{0} \text { de córregos de qualquer ordem e } 0 \\
\mathrm{n}^{\circ} \text { de córregos da maior ordem. }\end{array}$ \\
\hline Área $\left(\mathrm{km}^{2}\right)$ & 7,81 & \\
\hline $\begin{array}{l}\text { Frequencia de } \\
\text { drenagem } \\
\text { (Fs) }\end{array}$ & $\mathrm{Fs}=\Sigma \mathrm{Nu} / \mathrm{A}$ & Razão entre o no total de rios e a area da bacia \\
\hline
\end{tabular}




\subsubsection{Protocolo de Avaliação de Rápidos}

O Protocolo de Avaliação de Rápidos é uma ferramenta de avaliação ambiental que, segundo Dillenburg (2007), é útil para quantificar as características das condições naturais de um determinado trecho de rio, sendo de fácil avaliação preliminar dos ecossistemas lóticos, como também, de fácil aplicação, pois permite, também, comparações entre trechos dentro de mesma drenagem ou de bacias hidrográficas diferentes.

Esta técnica de avaliação é utilizada por segmentos no interior/ao longo de um rio, onde um conjuntos de dados são compartilhados, contendo pontuação, que varia de acordo com a realidade do local a se investigar, embora passível de erros.

Na versão de Hannafor, Barbour, e Resh (1997), as variáveis diferem das alterações feitas por Callisti et al. (2002), pois introduzem novas variáveis, como observados nas tabelas 19 a 21, cuja pontuação difere entre estas tabelas.

Dillenburg (2007) argumenta que este protocolo facilita a visualização da qualidade ambiental dos ambientes fluviais, além de ser uma ferramenta para ser aplicado e implementado nos programas de gerenciamento e preservação de bacias hidrográficas.

Sua aplicação consiste em responder um conjuntos de questões, na forma de um protocolo/ questionário, contendo 22 parâmetros, embora estes dados sejam segmentados em duas tabelas distintas, que por questão de formação foi subdividida por pontuação diferenciada.

Nas tabelas 19, 20 e 21, as variáveis que se encontram nas mesmas, estão relacionadas aos parâmetros ecológicos, antrópicos, aspéctos geotécnicos e hidroquímicos, embora a composição de ambas diferem entre sí. 
Tabela 19 - Protocolo de Avaliação Rápida da Diversidade de Habitats em trechos de bacias hidrográficas, modificado do protocolo da Agência de Proteção Ambiental de Ohio (EUA) (EPA, 1987). (Obs.: 4 pontos (situação natural), 2 e 0 pontos (situações leves ou severamente alteradas).

\begin{tabular}{|c|c|c|c|}
\hline \multirow[t]{2}{*}{ Parâmetros } & \multicolumn{3}{|c|}{ Pontuação } \\
\hline & 4 & 2 & $\mathbf{0}$ \\
\hline $\begin{array}{l}\text { 1.Tipo de ocupação das } \\
\text { margens do corpo } \\
\text { d'água (principal } \\
\text { atividade) }\end{array}$ & Vegetação Natural & $\begin{array}{c}\text { Campo de } \\
\text { Pastagem/Agricultura/ } \\
\text { Monocultura/ } \\
\text { Reflorestamento }\end{array}$ & $\begin{array}{c}\text { Residencial/ Comercial/ } \\
\text { Industrial }\end{array}$ \\
\hline $\begin{array}{l}\text { 2. Erosão próxima e/ou } \\
\text { nas margens do rio e } \\
\text { assoreamento em seu } \\
\text { leito }\end{array}$ & Ausente & Moderada & Acentuada \\
\hline 3. Alterações antrópicas & Ausente & $\begin{array}{c}\text { Alterações de Origem } \\
\text { Doméstica (Esgoto, Lixo) }\end{array}$ & $\begin{array}{l}\text { Alterações de Origem } \\
\text { Industrial/ Urbana } \\
\text { (Fábricas, Siderurgias, } \\
\text { Canalização, } \\
\text { Retilinização } \\
\text { do Curso do Rio) }\end{array}$ \\
\hline $\begin{array}{c}\text { 4. Cobertura } \\
\text { vegetal no leito }\end{array}$ & Parcial & Total & Ausente \\
\hline 5. Odor da água & Nenhum & Esgoto (Ovo Podre) & Óleo/Industrial \\
\hline 6. Oleosidade da água & Ausente & Moderada & Abundante \\
\hline $\begin{array}{l}\text { 7. Transparência da } \\
\text { água }\end{array}$ & Transparente & Turva/Cor de Chá-Forte & Opaca ou Colorida \\
\hline $\begin{array}{l}\text { 8. Odor do sedimento } \\
\text { (fundo) }\end{array}$ & Nenhum & Esgoto (Ovo Podre) & Óleo/Industrial \\
\hline 9. Oleosidade do fundo & Ausente & Moderado & Abundante \\
\hline 10. Tipo de fundo & Pedras/Cascalho & Lama/Areia & Cimento/Canalizado \\
\hline
\end{tabular}

As tabelas 20 e 21 apresentam 12 variáveis que compõem o protocolo de avaliação aqui exposto, cujos parâmetros foram divididos com limite de pontuação.

$\mathrm{Na}$ tabela 19, a pontuação é definida da seguinte forma: 0, 2 (situações leves ou severamente alteradas) e 4 (situação natural), ao passo que na tabela 20 esta divisão variou de: 0, 2, 3 (situações levemente severas ou severas) e 5 (situação normal). 
Tabela 20 - Protocolo de Avaliação Rápida da Diversidade de Habitats em trechos de bacias hidrográficas, modificado do protocolo de Hannaford et al. (1997). (Obs.: 5 pontos (situação natural), 3, 2 e 0 pontos (situações leve ou severamente alteradas).

\begin{tabular}{|c|c|c|c|c|}
\hline \multirow[t]{2}{*}{ Parâmetros } & \multicolumn{4}{|c|}{ Pontuação } \\
\hline & 5 & 3 & 2 & 0 \\
\hline 11. Tipos de fundo & $\begin{array}{l}\text { Mais de } 50 \% \text { com } \\
\text { habitats } \\
\text { diversificados; } \\
\text { pedaços de } \\
\text { troncos submersos; } \\
\text { cascalho ou outros } \\
\text { habitats } \\
\text { estáveis. }\end{array}$ & \begin{tabular}{|}
30 a $50 \%$ de habitats \\
diversificados; habitats \\
adequados para a \\
manutenção das \\
populações de \\
organismos \\
aquáticos.
\end{tabular} & $\begin{array}{c}10 \text { a } 30 \% \text { de habitats } \\
\text { diversificados; } \\
\text { disponibilidade de } \\
\text { habitats } \\
\text { insuficiente; substratos } \\
\text { frequentemente } \\
\text { modificados. }\end{array}$ & $\begin{array}{l}\text { Menos que } 10 \% \text { de } \\
\text { habitats } \\
\text { diversificados; } \\
\text { ausência de } \\
\text { habitats óbvia; } \\
\text { substrato } \\
\text { rochoso instável para } \\
\text { fixação } \\
\text { dos organismos. }\end{array}$ \\
\hline $\begin{array}{l}\text { 12. Extensão de } \\
\text { rápidos }\end{array}$ & $\begin{array}{c}\text { Rápidos e } \\
\text { corredeiras bem } \\
\text { desenvolvidas; } \\
\text { rápidos tão } \\
\text { largos quanto o rio e } \\
\text { com o } \\
\text { comprimento igual } \\
\text { ao } \\
\text { dobro da largura do } \\
\text { rio. }\end{array}$ & $\begin{array}{c}\text { Rápidos com a largura } \\
\text { igual à do rio, mas } \\
\text { com } \\
\text { comprimento menor } \\
\text { que o } \\
\text { dobro da largura do } \\
\text { rio. }\end{array}$ & $\begin{array}{c}\text { Trechos rápidos podem } \\
\text { estar } \\
\text { ausentes; rápidos não } \\
\text { tão } \\
\text { largos quanto o rio e } \\
\text { seu } \\
\text { comprimento menor que } \\
0 \\
\text { dobro da largura do rio. }\end{array}$ & $\begin{array}{l}\text { Rápidos ou } \\
\text { corredeiras } \\
\text { inexistentes. }\end{array}$ \\
\hline $\begin{array}{l}\text { 13. Frequência de } \\
\text { rápidos }\end{array}$ & $\begin{array}{c}\text { Rápidos } \\
\text { relativamente } \\
\text { frequentes; distância } \\
\text { entre } \\
\text { rápidos dividida pela } \\
\text { largura do rio entre } \\
5 \text { e } 7 .\end{array}$ & $\begin{array}{c}\text { Rápidos não } \\
\text { frequentes; } \\
\text { distância entre rápidos } \\
\text { dividida pela largura } \\
\text { do } \\
\text { rio entre } 7 \text { e } 15 .\end{array}$ & $\begin{array}{c}\text { Rápidos ou corredeiras } \\
\text { ocasionais; habitats } \\
\text { formados pelos } \\
\text { contornos do } \\
\text { fundo; distância entre } \\
\text { rápidos } \\
\text { dividida pela largura do } \\
\text { rio } \\
\text { entre } 15 \text { e } 25 \text {. }\end{array}$ & $\begin{array}{c}\text { Geralmente com } \\
\text { lâmina } \\
\text { d'água "lisa" ou com } \\
\text { rápidos } \\
\text { rasos; pobreza de } \\
\text { habitats; } \\
\text { distância entre rápidos } \\
\text { dividida pela }\end{array}$ \\
\hline $\begin{array}{l}\text { 14. Tipos de } \\
\text { substrato }\end{array}$ & $\begin{array}{l}\text { Seixos abundantes } \\
\text { (prevalecendo em } \\
\text { nascentes). }\end{array}$ & $\begin{array}{l}\text { Seixos abundantes; } \\
\text { cascalho comum. }\end{array}$ & $\begin{array}{c}\text { Fundo formado } \\
\text { predominantemente } \\
\text { por cascalho; alguns } \\
\text { seixos presentes. }\end{array}$ & $\begin{array}{l}\text { Fundo pedregoso; } \\
\text { seixos ou } \\
\text { lamoso. }\end{array}$ \\
\hline $\begin{array}{l}\text { 15. Deposição de } \\
\text { lama }\end{array}$ & $\begin{array}{l}\text { Entre } 0 \text { e } 25 \% \text { do } \\
\text { fundo } \\
\text { coberto por lama. }\end{array}$ & $\begin{array}{l}\text { Entre } 25 \text { e } 50 \% \text { do } \\
\text { fundo } \\
\text { coberto por lama. }\end{array}$ & $\begin{array}{l}\text { Entre } 50 \text { e } 75 \% \text { do } \\
\text { fundo } \\
\text { coberto por lama. }\end{array}$ & $\begin{array}{l}\text { Mais de } 75 \% \text { do fundo } \\
\text { coberto por lama. }\end{array}$ \\
\hline $\begin{array}{l}\text { 16. Depósitos } \\
\text { sedimentares }\end{array}$ & $\begin{array}{l}\text { Menos de } 5 \% \text { do } \\
\text { fundo com } \\
\text { deposição de lama; } \\
\text { ausência de } \\
\text { deposição nos } \\
\text { remansos. }\end{array}$ & $\begin{array}{c}\text { Alguma evidência de } \\
\text { modificação no fundo, } \\
\text { principalmente como } \\
\text { aumento de cascalho, } \\
\text { areia } \\
\text { ou lama; } 5 \text { a } 30 \% \text { do } \\
\text { fundo } \\
\text { afetado; suave } \\
\text { deposição } \\
\text { nos remansos. }\end{array}$ & $\begin{array}{c}\text { Deposição moderada } \\
\text { de } \\
\text { cascalho novo, areia ou } \\
\text { lama } \\
\text { nas margens; entre } 30 \text { a } \\
50 \% \\
\text { do fundo afetado; } \\
\text { deposição } \\
\text { moderada nos } \\
\text { remansos. }\end{array}$ & $\begin{array}{c}\text { Grandes depósitos de } \\
\text { lama, } \\
\text { maior } \\
\text { desenvolvimento } \\
\text { das margens; mais de } \\
50 \% \text { do fundo } \\
\text { modificado; } \\
\text { remansos ausentes } \\
\text { devido à } \\
\text { significativa deposição } \\
\text { de } \\
\text { sedimentos. }\end{array}$ \\
\hline $\begin{array}{l}\text { 17. Alterações no } \\
\text { canal do rio }\end{array}$ & $\begin{array}{l}\text { Canalização } \\
\text { (retificação) } \\
\text { ou dragagem } \\
\text { ausente ou } \\
\text { mínima; rio com } \\
\text { padrão } \\
\text { normal. }\end{array}$ & \begin{tabular}{|} 
Alguma canalização \\
presente, normalmente \\
próximo à construção \\
de \\
pontes; evidência de \\
modificações há mais \\
de 20 \\
anos.
\end{tabular} & $\begin{array}{c}\text { Alguma modificação } \\
\text { presente } \\
\text { nas duas margens; } 40 \text { a } \\
80 \% \\
\text { do rio modificado. }\end{array}$ & $\begin{array}{c}\text { Margens modificadas; } \\
\text { acima } \\
\text { de } 80 \% \text { do rio } \\
\text { modificado. }\end{array}$ \\
\hline
\end{tabular}


Tabela 21 - Continuação da tabela 60: Protocolo de Avaliação Rápida da Diversidade de Habitats em trechos de bacias hidrográficas, modificado do protocolo de Hannaford et al. (1997). (Obs.: 5 pontos (situação natural), 3, 2 e 0 pontos (situações leve ou severamente alteradas).

\begin{tabular}{|c|c|c|c|c|}
\hline \multirow[t]{2}{*}{ Parâmetros } & \multicolumn{4}{|c|}{ Pontuação } \\
\hline & 5 & 3 & 2 & 0 \\
\hline $\begin{array}{l}18 \text { Características } \\
\text { do fluxo das águas }\end{array}$ & $\begin{array}{c}\text { Fluxo } \\
\text { relativamente } \\
\text { igual } \\
\text { em toda a largura } \\
\text { do rio; } \\
\text { mínima } \\
\text { quantidade de } \\
\text { substrato exposta. }\end{array}$ & \begin{tabular}{|} 
Lâmina d'água \\
acima de \\
$75 \%$ do canal do rio; \\
ou \\
menos de $25 \%$ do \\
substrato \\
exposto.
\end{tabular} & $\begin{array}{l}\text { Lâmina d'água entre } \\
25 \text { e } 75 \% \text { do canal do } \\
\text { rio, e/ou maior parte } \\
\text { do substrato nos } \\
\text { "rápidos" exposto. }\end{array}$ & $\begin{array}{l}\text { Lâmina d'água } \\
\text { escassa e presente } \\
\text { apenas nos } \\
\text { remansos. }\end{array}$ \\
\hline $\begin{array}{l}\text { 19. Presença de } \\
\text { mata ciliar }\end{array}$ & \begin{tabular}{|c|} 
Acima de $90 \%$ \\
com \\
vegetação ripária \\
nativa, \\
incluindo árvores, \\
arbustos \\
ou macrófitas; \\
mínima \\
evidência de \\
deflorestamento; \\
todas as \\
plantas atingindo \\
a altura \\
"normal".
\end{tabular} & $\begin{array}{c}\text { Entre } 70 \text { e } 90 \% \text { com } \\
\text { vegetação ripária } \\
\text { nativa; } \\
\text { deflorestamento } \\
\text { evidente } \\
\text { mas não afetando o } \\
\text { desenvolvimento da } \\
\text { vegetação; maioria } \\
\text { das } \\
\text { plantas atingindo a } \\
\text { altura } \\
\text { "normal". }\end{array}$ & $\begin{array}{c}\text { Entre } 50 \text { e } 70 \% \text { com } \\
\text { vegetação ripária } \\
\text { nativa; } \\
\text { deflorestamento } \\
\text { óbvio; } \\
\text { trechos com solo } \\
\text { exposto ou } \\
\text { vegetação eliminada; } \\
\text { menos } \\
\text { da metade das } \\
\text { plantas } \\
\text { atingindo a altura } \\
\text { "normal". }\end{array}$ & $\begin{array}{c}\text { Menos de } 50 \% \text { da } \\
\text { mata ciliar } \\
\text { nativa; } \\
\text { deflorestamento } \\
\text { muito acentuado. }\end{array}$ \\
\hline $\begin{array}{l}20 \text { Estabilidade } \\
\text { das margens }\end{array}$ & $\begin{array}{c}\text { Margens estáveis; } \\
\text { evidência de } \\
\text { erosão } \\
\text { mínima ou } \\
\text { ausente; } \\
\text { pequeno potencial } \\
\text { para } \\
\text { problemas futuros. } \\
\text { Menos } \\
\text { de } 5 \% \text { da margem } \\
\text { afetada. }\end{array}$ & $\begin{array}{c}\text { Moderadamente } \\
\text { estáveis; } \\
\text { pequenas áreas de } \\
\text { erosão } \\
\text { frequentes. Entre } 5 \\
\text { e 30\% } \\
\text { da margem com } \\
\text { erosão. }\end{array}$ & $\begin{array}{l}\text { Moderadamente } \\
\text { instável; } \\
\text { entre } 30 \text { e } 60 \% \text { da } \\
\text { margem } \\
\text { com erosão. Risco } \\
\text { elevado de } \\
\text { erosão durante } \\
\text { enchentes. }\end{array}$ & $\begin{array}{c}\text { Instável; muitas } \\
\text { áreas com } \\
\text { erosão; frequentes } \\
\text { áreas } \\
\text { descobertas nas } \\
\text { curvas do } \\
\text { rio; erosão óbvia } \\
\text { entre } 60 \text { e } \\
100 \% \text { da margem. }\end{array}$ \\
\hline $\begin{array}{l}\text { 21. Extensão de } \\
\text { mata ciliar }\end{array}$ & $\begin{array}{c}\text { Largura da } \\
\text { vegetação ripária } \\
\text { maior que } 18 \mathrm{~m} ; \\
\text { sem influência de } \\
\text { atividades } \\
\text { antrópicas } \\
\text { (agropecuária, } \\
\text { estradas, etc.). }\end{array}$ & $\begin{array}{c}\text { Largura da } \\
\text { vegetação ripária } \\
\text { entre } 12 \text { e } 18 \mathrm{~m} ; \\
\text { mínima influência } \\
\text { antrópica. }\end{array}$ & $\begin{array}{c}\text { Largura da vegetação } \\
\text { ripária } \\
\text { entre } 6 \text { e } 12 \mathrm{~m} ; \\
\text { influência antrópica } \\
\text { intensa. }\end{array}$ & \begin{tabular}{|c|} 
Largura da \\
vegetação ripária \\
menor que $6 \mathrm{~m} ;$ \\
vegetação restrita \\
ou ausente devido à \\
atividade antrópica.
\end{tabular} \\
\hline $\begin{array}{l}\text { 22. Presença de } \\
\text { plantas Aquáticas }\end{array}$ & $\begin{array}{c}\text { Pequenas } \\
\text { macrófitas } \\
\text { aquáticas e/ou } \\
\text { musgos } \\
\text { distribuídos pelo } \\
\text { leito. }\end{array}$ & $\begin{array}{c}\text { Macrófitas aquáticas } \\
\text { ou algas } \\
\text { filamentosas ou } \\
\text { musgos distribuídas } \\
\text { no rio, } \\
\text { substrato com } \\
\text { perifiton. }\end{array}$ & $\begin{array}{c}\text { Algas filamentosas } \\
\text { ou macrófitas em } \\
\text { poucas pedras ou } \\
\text { alguns remansos, } \\
\text { perifiton abundante e } \\
\text { biofilme. }\end{array}$ & $\begin{array}{c}\text { Ausência de } \\
\text { vegetação aquática } \\
\text { no leito do rio ou } \\
\text { grandes bancos } \\
\text { macrófitas } \\
\text { (p.ex. aguapé). }\end{array}$ \\
\hline
\end{tabular}


Através do somatório total de cada variável, obtem-se a classificação quanto ao nível de preservação da condição ecológica, que corresponde à seguinte pontuação: entre 0 a 40 pontos representa trecho definido como sendo "impactado"; 41 a 60 pontos representam trechos "alterado"; e acima de 61 pontos, trechos "natural" (KRUPEK, 2010) como se observa na tabela 22.

Quanto à aplicação deste formulário de avaliação ambiental, Hannaford; Barbour; Resh (1997) demostraram que um treinamento prévio, influencia na qualidade dos dados coletados.

Através do somatório total de cada variável, obtem-se a classificação quanto ao nível de preservação da condição ecológica, que corresponde à seguinte pontuação: entre 0 a 40 pontos representa trecho definido como sendo "impactado"; 41 a 60 pontos representam trechos "alterado"; e acima de 61 pontos, trechos "natural" (KRUPEK, 2010) como se observa na tabela 22.

A aplicação deste tipo de avaliação pode ter as mais diferentes finalidades, dentre elas, a avaliação da diversidade de ecossistemas fluviais em comparação com uso de macroinvertebrados bentônicos como bioindicadores de qualidade destes ambientes (CALISTO; MORETTI; GOULART, 2001), embora estes autores citados investigaram quatro corpos lenticos do município de Belo Horizontes/MG, a partir das 11 variáveis (1.tipo de fundo; 2.largura dos remansos, 3.frequência de remansos, 4.tipos de substrato, 5.deposição de lama, 7.depósitos sedimentares, 8.alteração no canal do rio, 9.características do fluxo das águas, 10.presença de vegetação ripária, 11.estabilidade das margens e extensão da vegetação ripária) com alterações/simplificações da propostas por Hannaford; Barbour; Resh (1997).

Quanto às aplicações deste protocolo, Callisto et al. (2002) comentam que o mesmo pode ser usado em atividades de pesquisa e ensino, já que o mesmo se baseia na caracterização das condições ecológicas em trechos de bacias hidrográficas, tendo sido aplicado para fins educacionais durante as aulas práticas de disciplinas de ecologia, em alguns rios e córregos no Parque Nacional da Serra do Cipó (MG) e Parque Nacional da Bocaina (RJ).

O estudo feito por Xavier \& Teixeira (2007) apresentou o seguinte resultado para 464 nascentes perenes da bacia hidrográfica do Rio São João (Itaúna - MG) para um total de 58 córregos, $148(31,89 \%)$ das nascentes encontravam-se 
impactadas, 219 (47,2\%) encontravam-se alteradas, e apenas 97 (20,91\%) encontravam-se em estado natural.

Tabela 22 - Distribuição dos pontos do Protocolo de Avaliação de Rápidos (adaptado de Callixto et al., 2002; XAVIER \& TEIXEIRA, 2007).

\begin{tabular}{|c|c|c|}
\hline Pontuação & Classificação & Caracterização \\
\hline$>62$ & Naturais & $\begin{array}{l}\text { Quando apresentavam pelo menos } 50 \text { m de vegetação natural } \\
\text { em torno do olho d'água em nascentes pontuais ou a partir do } \\
\text { olho d'água principal em nascentes difusas; vegetação ripária } \\
\text { natural no trecho de } 300 \text { m a partir do olho d'água em ambas as } \\
\text { margens; influência antrópica mínima ou ausente. }\end{array}$ \\
\hline $55-61$ & Pouco Alterados & $\begin{array}{l}\text { Quando não apresentam } 50 \mathrm{~m} \text { de vegetação natural em seu } \\
\text { entorno e vegetação ripária natural no trecho de } 300 \mathrm{~m} \text {, mas } \\
\text { apresentam bom estado de conservação, apesar de serem } \\
\text { ocupadas por poucas pastagem/agricultura ou pequenas } \\
\text { influências antrópicas. }\end{array}$ \\
\hline $48-54$ & Média Alteração & $\begin{array}{l}\text { Quando não apresentam } 50 \text { m de vegetação natural em seu } \\
\text { entorno e vegetação ripária natural no trecho de } 300 \mathrm{~m} \text {, mas } \\
\text { apresentam bom estado de conservação, apesar de serem } \\
\text { ocupadas por pastagem/agricultura ou influências antrópicas } \\
\text { mais acentuadas. }\end{array}$ \\
\hline $41-47$ & Muito Alterados & $\begin{array}{l}\text { Quando não apresentam } 50 \mathrm{~m} \text { de vegetação natural em seu } \\
\text { entorno e vegetação ripária natural no trecho de } 300 \mathrm{~m} \text {, mas } \\
\text { apresentam estado de conservação ruim, apesar de serem } \\
\text { ocupadas por pastagem/agricultura ou grandes influências } \\
\text { antrópicas. }\end{array}$ \\
\hline $0-40$ & Impactados & $\begin{array}{l}\text { Quando se encontram com alto grau de perturbação no entorno } \\
\text { de } 50 \text { m do olho d'água e vegetação ripária no trecho de } 300 \text { m; } \\
\text { solo compactado; presença intensa de gado; presença de } \\
\text { erosões e voçorocas. Influência intensa de atividade antrópica. }\end{array}$ \\
\hline
\end{tabular}

De acordo com o estudo feito por Figueiredo (2009) a respeito do rio Sapucaí Mirim, no trecho de Conceição dos Ouros a Cachoeira de Minas (MG), classificou-se este curso rio como sendo, predominantemente, "alterado", pois em um total de 10 avaliações (segmentos do rio), 7 pontos foram avaliados como alterado e 3 delas foram definidos como sendo "natural". 
No trabalho feito por Schneider et al. (2011) para o Córrego da Barrinha (Pirassununga, SP), comparando os resultados obtidos pelo uso deste protocolo com análise da concentração de Fósforo e Nitrogênico, indicou que ambas as técnicas indicaram que a água deste córrego se encontrava com boa qualidade, quanto à concentração de Fósforo e Nitrogênico e cujos limites estavam muito abaixo do limite máximo permitido pela legislação brasileira. 


\section{CARACTERIZAÇÃO FISIOGRÁFICA DA ÁREA DE ESTUDO}

\subsection{Caracterização regional do Meio Físico}

A região em que a área de estudo está localizada, é climaticamente classificada, como sendo tropical úmido $(A w)$, com verão de grandes precipitações pluviométricas e invernos relativamente seco (RODRIGUES, 2007).

Sua temperatura anual é de $24,9^{\circ} \mathrm{C}$, cuja média mensal máxima é de $27,3^{\circ} \mathrm{C}$ no mês de março e mínima de $24,9^{\circ} \mathrm{C}$ em julho (KÖPPEN \& GEIGER, 1928; RODRIGUES, 2007).

Do ponto de vista geomorfológico, o domínio dos mares de morros é observado na porção noroeste do Estado de São Paulo, em especial em torno da área de estudo, cujos topos das colinas encontram-se arredondados e aplainados, como também, suas vertentes são retilíneas tendendo a convexa (RODRIGUES, 2007).

A área de estudo está inserida, regionalmente, na Bacia do Paraná, na Unidade Morfo-escultural Planaltos e Chapadas da Bacia do Paraná (ROSS, 1985), que engloba terrenos sedimentares cujas idades, variam desde o Devoniano ao Cretáceo, incluindo extensa ocorrência de rochas vulcânicas básicas e ácidas JuraCretácica, na porção sul desta entidade geológica.

Segundo o CPRM (2009) esta bacia, correspondente à porção Sul-Americana desta grande entidade geológica, recobre uma área de aproximadamente 1.6×106 $\mathrm{km}^{2}$, enquanto que na porção da América do Sul (Paraná e Bacia do Chaco-Paraná), sua área total é de $1.400 .000 \mathrm{~km}^{2}$ (QUINTAS, 2002).

Segundo Rodrigues (2007), o processo de formação da mesma ocorreu no início do Neocretáceo, após a ruptura do continente gondwânico, no centro-sul da Plataforma Sul-Americana, onde esta bacia é tida como interiorana, desenvolvida por compensação isostática, decorrente do acúmulo de quase $2.000 \mathrm{~m}$ de lavas basálticas, ocorrido no Eocretáceo (magmatismo Serra Geral).

A comentada bacia sedimentar metamorfisada é do tipo intracratônica, de idade Siluro-Ordoviciana (QUINTAS, 2002), que foi influenciada por quatro grandes episódios (ALMEIDA, 1981), que segundo SLOSS (1963), foram caracterizados como um ciclo tectono-sedimentar completo, sendo que os dois primeiros ciclos 
estão relacionados à sedimentação em uma bacia sinforme subsidente, e os dois últimos correspondendo às fases de soerguimento e extrusão de grande quantidade de lavas toleíticas relacionadas ao intumescimento da crosta ocorrido ao redor de 135 - $120 \mathrm{Ma}$ (CPRM, 2009).

A bacia do Paraná apresenta um formato alongado, com orientação NNE-SSO, tendo aproximadamente $1.750 \mathrm{~km}$ de comprimento e largura média de $900 \mathrm{~km}$, apresentando derrames de lava basáltica em dois terços da porção brasileira, e os valores máximos de espessura de rochas sedimentares e vulcânicas são da ordem de 6.000m (QUINTAS, 2002).

A sequência deposicional de sedimentação é predominantemente arenosa, correspondente a um paleoclima semi-árido a árido, com aproximadamente $300 \mathrm{~m}$ de espessura máxima preservada e área de $370.000 \mathrm{~km}^{2}$; sequência suprabasáltica neocretácea (SSN) composta por substrato de rochas vulcânicas, em especial, basaltos da Formação Serra Geral (Grupo São Bento), cujo limite superior da sequência é erosivo, demarcado pela Superfície Sul-Americana ou sua posterior dissecação (RODRIGUES, 2007).

A compartimentação geológica regional é feita por sedimentos Cretáceos do Grupo Bauru, que se sobrepõem aos basaltos Juro-cretáceos da Formação Serra Geral e são sobrepostos por depósitos Tércio-Quaternários de colúvios e aluviões (QUINTAS, 2002; RODRIGUES, 2007).

O Grupo Bauru, na porção localizada no interior do Estado de São Paulo, é segmentado, segundo SOARES et al., (1980) apud SILVA (2003) como sendo: Formação Caiuá, Santo Anastácio, Adamantina (incluindo litofácies Ubirajara, Taciba e São José do Rio Preto) e Marília (incluindo a litofácie Itaqueri).

De acordo com Silva (2003), o prosseguimento da sedimentação Bauru (evento ocorrido em toda a bacia), com os depósitos fluviais da Formação Adamantina transgrediu sobre a Formação Araçatuba, representando o início do estágio final da bacia. Sendo que nesta fase, o sistema fluvial avançou, primeiramente, sobre os sedimentos da Santo Anastácio na porção oeste, preservados nas margens do sistema lacustre, os basaltos a leste, como também depósitos pelíticos da Formação Araçatuba, nas áreas centrais. 
Os materiais geológicos da Formação Serra Geral são marcados pela presença de massa basáltica, com densidade e profundidade do pacote variado, refletindo no conteúdo mineralógico (DNPM, 1984).

Para Abreu (2007), estes derrames basáltcos são fisicamente caracterizados, como sendo rochas afaníticas, variando de cinza escura a preta, podendo formar solos argilosos plásticos, de cor marrom, com espessura de $1 \mathrm{~m}$ e subhorizontal, no contato geolígico entre este corpo rochoso com a Formação Botucatu (Região de Analândia, SP).

O grupo Bauru possui características litológicas sedimentares e paleontológicas corroborando para classificações paleoambientais continental, fluvial e lacustre (SCHNEIDER et al., 1974 apud DNPM, 1984).

Com base nas condições geológicas da área de estudo, percebeu-se que em seu interior ocorre o conto geológico entre três entidades distintas (Grupo Bauru: Formação Vale do Rio do Peixe; Grupo Caiuá: Formação Vale do Rio do Peixe, e; Grupo São Bento: Formação Serra Geral).

O grupo Bauru está localizado na porção central da Bacia do Paraná, podendo atingir uma espessura de $300 \mathrm{~m}$, sendo segmentado pelas fdoemações caiuá, Santo Anastácio e Adamantina (SUÁREZ, 2002).

De acordo com Carvalho (2000), a Formação Santo Anastácio é um dos membros estratigráficos que compõem o Grupo Bauru, tendo como caracterísitica, a presença de arenitos finos, avermelhados, com acamamento horizontal e estratificações cruzadas de baixo ângulo, podendo ocorrer intercalações de níveis de argilito, cujos ambientes deposicionais teriam sido oriundos de rios meandrantes e anastomosados.

Esta formação é compartimentada em unidade superior, intermediária e superior, apesar da área de estudo está posicionada na unidade intermediária, que tem como característica geral, espessura do pacote sedimentar em $26 \mathrm{~m}$, presença de arenito avermelhado-claro a esverdeado, fino a médio, com teor de matriz siltitica variável, em padrão de fining up e eventualmente coarsening up, com raras estratificações e laminações cruzadas de baixo ângulo (PAULA E SILVA et al. 2006). 
Segundo Batezelli et al. (2003), os arenitos da Formação Santo Anastácio encontram-se entre os Grupos Bauru e Caiuá, marcando o início do novo ciclo de sedimentação.

A citada formação apresenta distribuição e espessuras variáveis nos diferentes compartimentos da bacia (PAULA E SILVA, 2003 apud Paula e Silva; CHANG; CAETANO-CHANG, 2003).

Para Arid; Barcha; Mezzalira (1981), o Grupo Bauru possui granulação mais fina que o Caiuá e a fácies Santo Anastácio, não varia de tamanho sistematicamente, ao longo de todo o perfil vertical (arredondamento médio de 0,54.

A Formação do Vale do Rio do Peixe tem espessura preservada de aproximadamente $100 \mathrm{~m}$, repousando diretamente sobre o basalto da Formação Serra Geral (Grupo São Bento) é (FERNANDES \& COIMBRA, 2000).

Quanto aos materiais residuais da Formação Serra Geral, Zuquette \& Palma (2006) comentam que os mesmos são encontrados nos topos dos morros, possuindo pequenas espessuras, cujos materiais são compostos por argilo-minerais, quartzo, hidróxidos de ferro, magnetita e ilmenita, além de alguns minerais primários nas camadas de rochas alteradas e solos residuais provenientes de rochas areníticas.

Os solos existentes no interior da bacia são predominantemente Latossólicos e são distribuídos ao longo das vertentes, com perfis retilíneos e convexos (IPT, 1981a apud CAMPUS et al., 2007), embora na área de estudos, os mesmos não foram formandos pelo processo pedogenético clássico, porém, na forma de depósitos sedimentares pedogenisados, podendo ser considerados como "Neossolos" seguidos de sua gênese, como Neossolo Quartzarênico e Neossolo Litólico.

Nas posições mais elevadas e planas dessas colinas encontram-se os Latossolos Vermelhos textura média, cujo material de origem derivou-se principalmente de arenitos da Formação Santo Anastácio, e estes transacionam, encosta abaixo, para Latossolos Vermelhos eutroférricos textura argilosa, originados principalmente dos produtos da alteração dos basaltos Formação Serra Geral (IPT, 1981b apud Campus et al., 2007).

Os solos residuais são formados por areia fina pouco argilosa, raramente com estratificação preservada, com resistência geomecânica por SPT (compacidade) 
variando de fofa a muito compacta, cuja coloração, predominantemente, marrom avermelhada (RODRIGUES, 2007).

Quanto aos materiais coluvionares, Rodrigues (2007) comenta que sua espessura é bastante irregular, com tendência a espaçamento nos vales rumo aos altos topográficos.

De acordo com Rodrigues (2007), os aluviões mais desenvolvidos podem ser encontrados ao longo da calha do Rio Tietê, abaixo da cota $300 \mathrm{~m}$, embora pequenos depósitos sejam observados nos vales das drenagem secundária.

Estes depósitos repousam ao longo dos vales das drenagens secundárias da região em contato discordante erosivo sobre a Formação Serra Geral em sua área de exposição e sobre os depósitos coluvionares ou da Formação Santo Inácio (RODRIGUES, 2007).

A Formação Rio Paraná ocorre em Pereira Barreto ao longo da margem direita do reservatório e é composta por arenitos marrom-avermelhados a arroxeados, de granulação fina a muito fina com composição quartzosa bem selecionada e com grãos arredondados (LEITE, 2005).

Nessa área predominam os Latossolos, distribuídos ao longo das vertentes, com perfis retilíneos e convexos (IPT, 1981a apud CAMPUS et al., 2007).

O comportamento geotécnico dos solos, que fazem parte da Formação Serra Geral, varia ao longo desta formação geológica, como observado na a região noroeste do Rio Grande do Sul, sendo estes solos formados, predominanteente por argilominerais esmectíticos, cujos valores de ângulo de atrito residual variaram entre $5^{\circ}$ a $10^{\circ}$. (RIGO, 2004).

\subsection{Caracterização geoambiental do Córrego das Cruzes}

O Córrego das Cruzes é classificado de acordo com Strahler (1964), como sendo de segunda ordem, cujo vale fluvial apresenta-se com declividades variando de plano à forte ondulado, que espacialmente, está inserido em uma feição geomorfológica do tipo mares de morros, formado por sedimentos inconsolidados de um segmento da Bacia do Paraná. 
Com relação à fração sedimentológica dos materiais geológicos, o Córrego das Cruzes é formado, predominantemente, por materiais arenosos, variando de fina a média, com variações distintas de silte e argila.

Embora o segmento em questão faça parte da bacia do Paraná, cuja bacia sofreu eventos tectônicos, feições geradas por tectonismo, como por exemplo, slickensides, não foram observadas, já que inicialmente pensou-se haver influência deste processo na área de estudo, por conta do lineamento estrutural das vertentes, com sentido NW-SW, apesar do mergulho das camadas geológicas seguem discordantes, em relação ao sentido da drenagem, dando indicativo de atividade tectônica.

No entanto, a drenagem em questão, em escala regional apresenta lineamento estrutural de sentido NW-SW, cuja forma tende a ser de um meandro encaixado, que se prolonga de forma subsequênte as camadas geológicas (orientação N-S).

Nestas modificações de caráter paleoclimático, que deram origem aos depósitos arenosos com afinamento dos materiais geológicos (fining upward), como comentado por Silva (2003), foram observados na área do Córrego das Cruzes, incluindo uma camada contendo seixos sub-angulosos e sub-arredondados, com expessura variando entre 15 a $50 \mathrm{~cm}$, aflorando em ambos os lados das márgens do córrego em questão.

O que corroboraria com a idéia de mudança paleoambiental e climática; além desta camada que teria sido criada em evento de tempestade, já que o formato dos seixos e cascalhos presentes neste acamamento não foram retrabalhados, com característica de seixos fluviais, e sim transportados ao longo da rampa, já que o curso d'água em foco, cortou uma porção desta camada, em um nível de lâmina d'água bem diferente do atual, por conta da inclinação do terreno.

Estes sedimentos ocorrem de forma estratificada, cujo mergulho não acompanha o sentido do terreno, sendo que, o próprio rio segue um caminho variado, ora o mergulho topográfico, ora não, fortemente observado em dois trechos com contato litológico formado por arenito alterado, contendo materiais geológico ferrosos e no outro segmento, arenito rico em micas, levemente alterado (ver figuras 13 e 14). 
Do ponto de vista geotécnico, a área sofre com problemas relacionados à produção e acúmulo de sedimentos, oriundos da remobilização dos materiais geológicos expostos á ação intempérica, induzido palo uso e ocupação da área de estudo, como observado in-situ, pela compactação do solo feita pelo pisoteio do gado ao solo, ao ponto de criar trilhas, facilitando assim, o escoamento das águas pluviais encosta abaixo, posto que estas trilhas ocorrem entre as vertentes em direção ao canal fluvial, como se observa na figura 11, contendo a distribuição espacial destes problemas ao longo da área do córrego.

Vale salientar que feições erosivas foram observadas ao longo da área de estudo, na forma de erosão linear, ravinamento das vertentes e voçoroca (ver figuras 15 e 16).

Neste espaço degradado, observou-se que a inesistência de mata ciliar, por conta do uso predatório do local, no qual algumas árvores (10 unidades dispersas) foram levantadas, embora não tenha sido feito o registro das mesmas, por conta da escala cartográfica, já que as mesmas seriam representadas como pontos, nas escalas de adotadas (ver figuras 17 e 18).

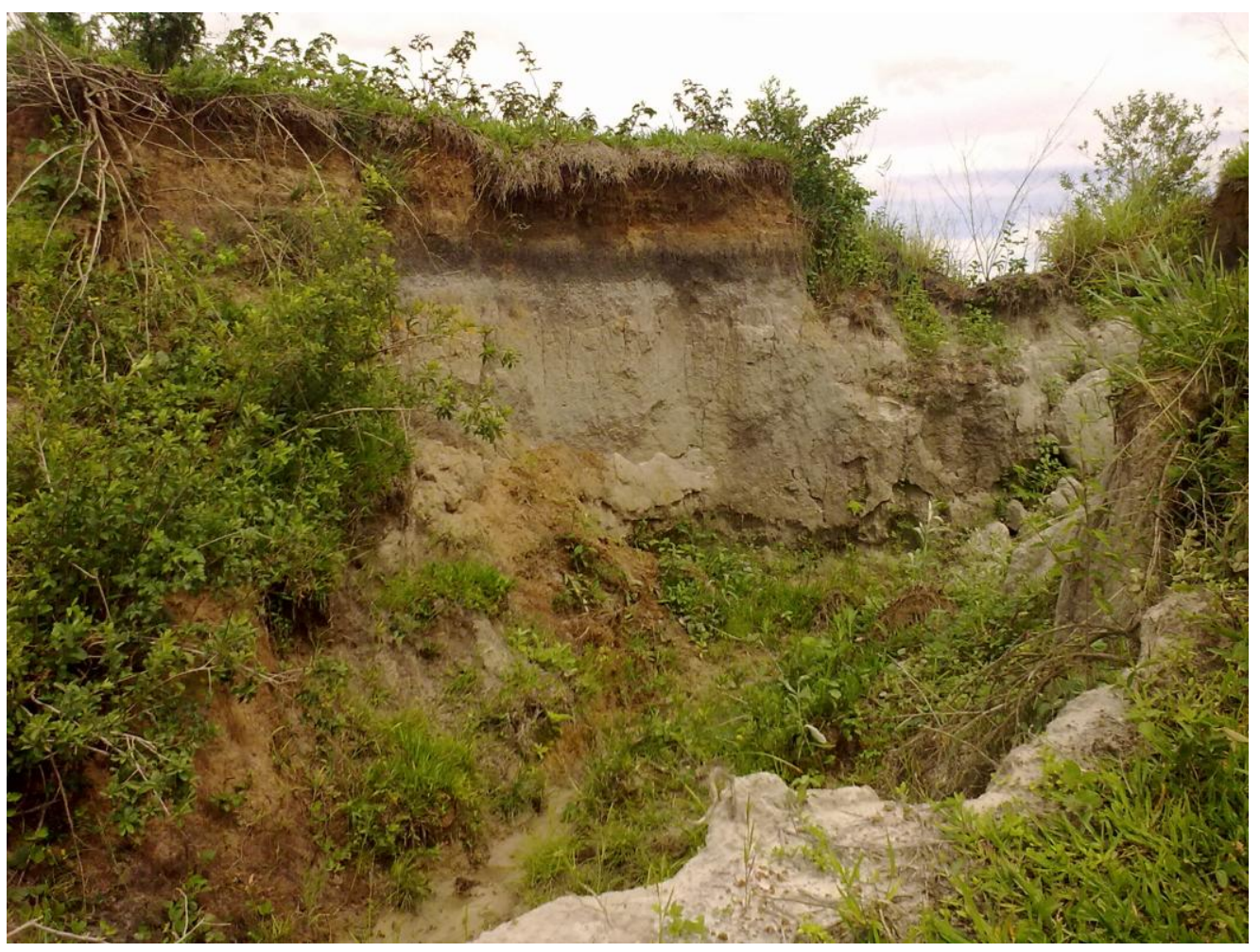

Figura 11 - Feição erosiva do tipo ravina, na margem esquerda do Córrego das Cruzes (Autor: E. J. Albuquerque Sobrinho). 
Alteração do uso, também foi constatada já que até o primeiro semestre de 2011, a área era usada para pastagem livre, com aproximadamente 20.000 bois, onde estes animais utilizavam o Córrego das Cruzes para tomar água (ver fig. 12), e atualmente os mesmos foram transportados para outras fazendas da região.

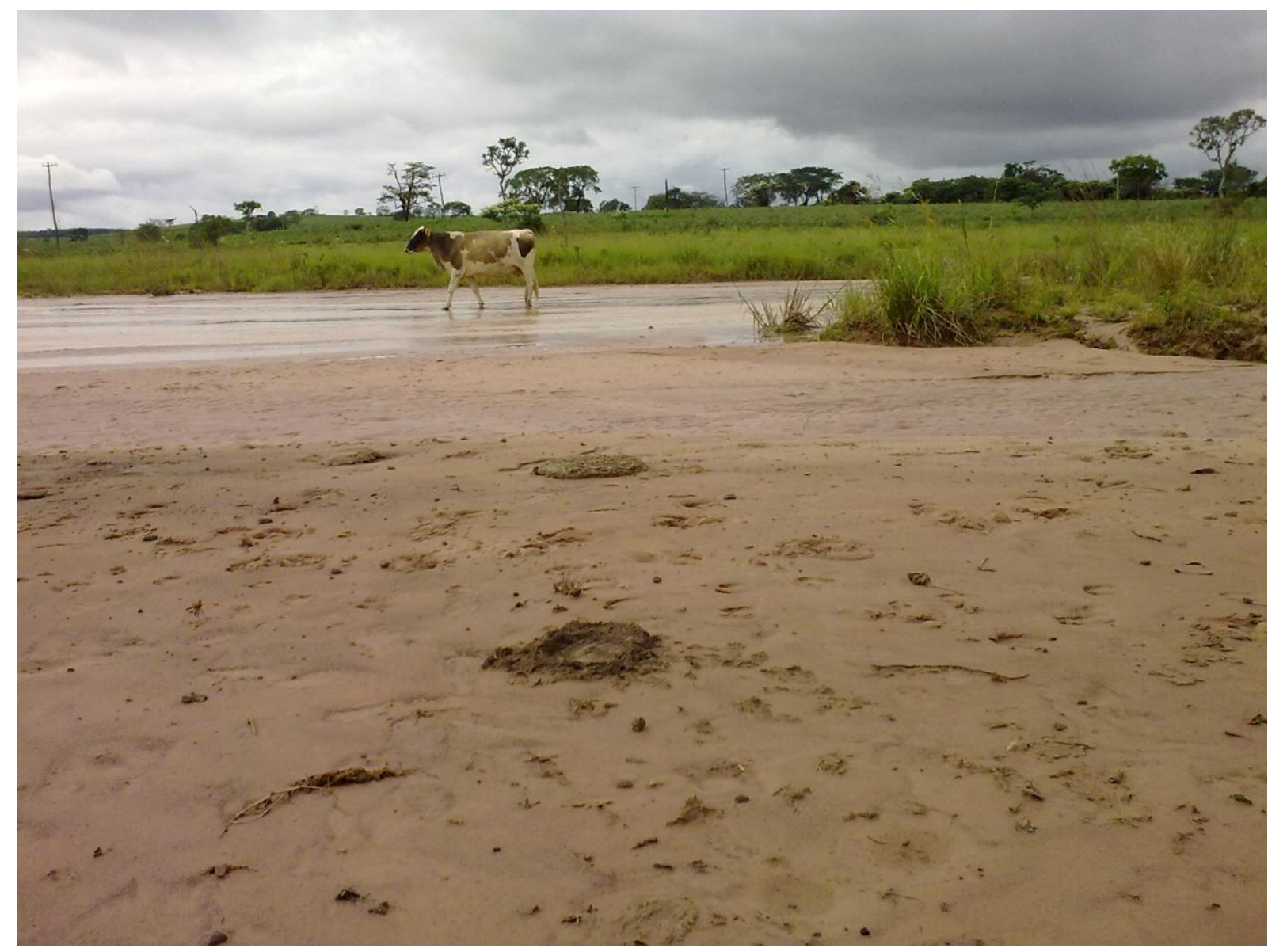

Figura 12 - Uso da área para pastagem em janeiro de 2011 (Autor: E. J. Albuquerque Sobrinho). 
Figura 13 - Carta geológica do Córrego das Cruzes (Santo Antônio do Aracanguá, SP). 
Figura 14 - Planta geológica do Córrego das Cruzes (Santo Antônio do Aracanguá, SP): Folhas 1, 2, 3 e 4. 
Figura 15 - Carta dos materiais geológicos do Córrego das Cruzes (Santo Antônio do Aracanguá, SP). 
Figura 16 - Planta dos materiais geológicos do Córrego das Cruzes (Santo Antônio do Aracanguá, SP): Folhas 1, 2 , 3 e 4. 
Figura 17 - Planta dos problemas geotécnicos do Córrego das Cruzes (Santo Antônio do Aracanguá, SP), Folhas 1, 2,3 e 4. 
Figura 18 - Carta dos problemas geotécnicos do Córrego das Cruzes (Santo Antônio do Aracanguá, SP). 


\section{MATERIAIS E MÉTODOS}

Para o desenvolvimento da presente tese, optou-se em empregar o método sistêmico, já que os dados levantados e trabalhados aqui, compõem um conjunto de informações que dialogam entre si, como observado na figura 19.

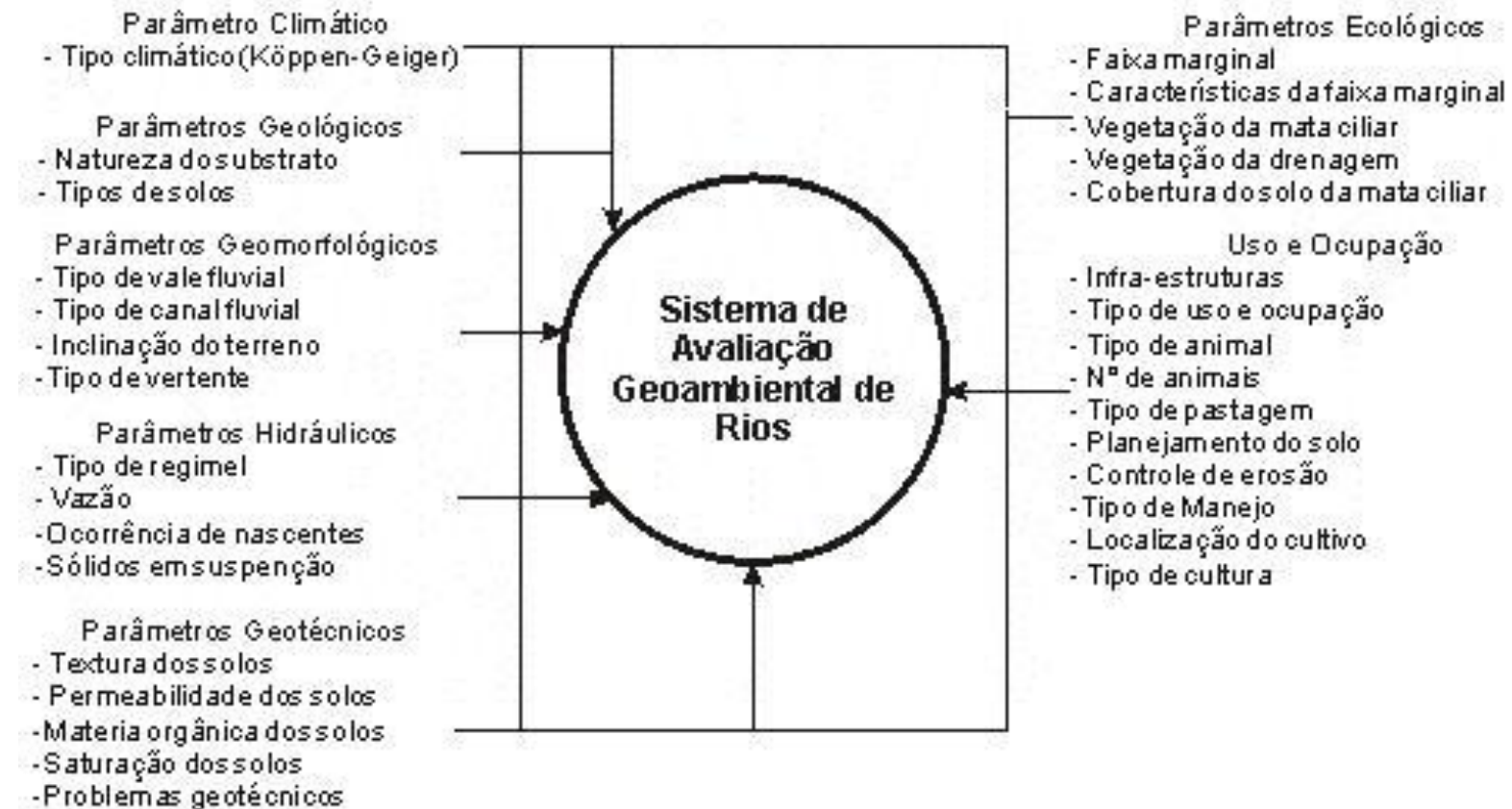

Figura 19 - Componentes do sistema de avaliação proposto.

A interação entre as variáveis deste sistema, embora não seja totalmente fechado, pode interferir no fluxo de matéria e energia, promovendo a degradação ambiental.

Por conta disto, empregou-se técnicas distintas durante a fase de coleta e tratamento das informações.

Como a morfologia da área de estudo e a escala de observação adotada não dificultavam o uso, por exemplo, de imagem de satélite, optou-se em elaborar o mapa básico, partindo dos dados oriundos de um levantamento topográfico e topobatimétrico distinto, de modo a ter a representação do relevo em questão, em uma escala que permitisse a documentação gráfica na forma de mapa, que a partir da sua materialização em meio digital, foi usado na elaboração dos mapas temáticos. 
Apesar da realização da topografia no encontro entre o córrego em questão com o ribeirão de mesmo nome, optou-se em não juntar as bases levantadas por questões operacionais, embora os dados coletados no rinbeirão tenha sido usado nos parâmetros morfométricos.

Para a elaboração do levantamento plani-altimétrico e topobatimétrico, empregou-se a Estação Total Leica, modelo TCR4007 e prismas ópticos pertencentes ao núcleo de hidrometria, cujo levantamento foi realizado durante os anos de 2010 (janeiro) e 2011 (janeiro e julho), totalizando em 11 dias de atividades realizadas em campo.

Este equipamento é empregado para medição de ângulos e distâncias, em feições existentes no terreno, que em seguida podem ser usados na delimitação de áreas, transportes de coordenadas de um ponto conhecido para outros previamente definidos.

\subsection{Levantamento Topográfico e Topobatimétrico por Estação Total}

Um dos equipamentos usados na coleta de dados sobre a variação altimétrica de uma determinada porção da superfície (natural e construída) é feito por Estação Total.

Este equipamento permite medir ângulos e distâncias entre a base/estação de referência (equipamento devidamente posicionado sobre uma estação, onde é feito a leitura entre ela e os pontos intervisíveis que se quer representar) e o prisma ótico (o laser emitido pela estação total é refletido de volta entre o prisma e a estação total, onde este prisma deve estar devidamente posicionado no local que se quer coletar a informação).

Vale salientar que o levantamento topográfico ocorreu além do espaço definido como faixa marginal, visando ter uma representação cartográfica do relevo da área de estudo.

Os equipamentos citados acima foram usados, simultâneamente, no levantamento da profundidade do córrego em questão, devido à baixa profundiddade encontrada ao longo de sua área, exceto em sua desembocadura com o ribeirão de 
mesmo nome, cuja profundidade não permitiu o uso da estação total, adotando-se em seguida, um levantamento ecobatimétrico na desembocadura à partir de duas seções ecobatimétricas (ver tópico 6.2).

Em ambas as técnicas, foram adotadas as recomentações fornecidas pela NBR 13.133 (1994).

No caso da topografia, a técnica adotada teve como base o nivelamento geométrico com mudança de estações, onde marcos topográficos em madeira foram materializados/fixados ao longo da área de estudo de forma intervisível, de modo a permitir leituras de ré e (a)vante entre as estações de controle e de vante entre estas estações e os pontos de medição, quando ocorria alteração na topografia ou não fosse possível observar o local.

Os equipamento utilizados, pertencentes ao Núcleo de Hidrometria do CRHEA da EESC/USP, foram (ver também a figura 20):

- Estação total Leica: TCR4007, Nº de Série: 748888;

- Receptor de GPS: Leica GS-20, Nº de Série: 11677;

- Antena do Receptor de GPS: LANDSTAR MK4, Nº de série: 4637.
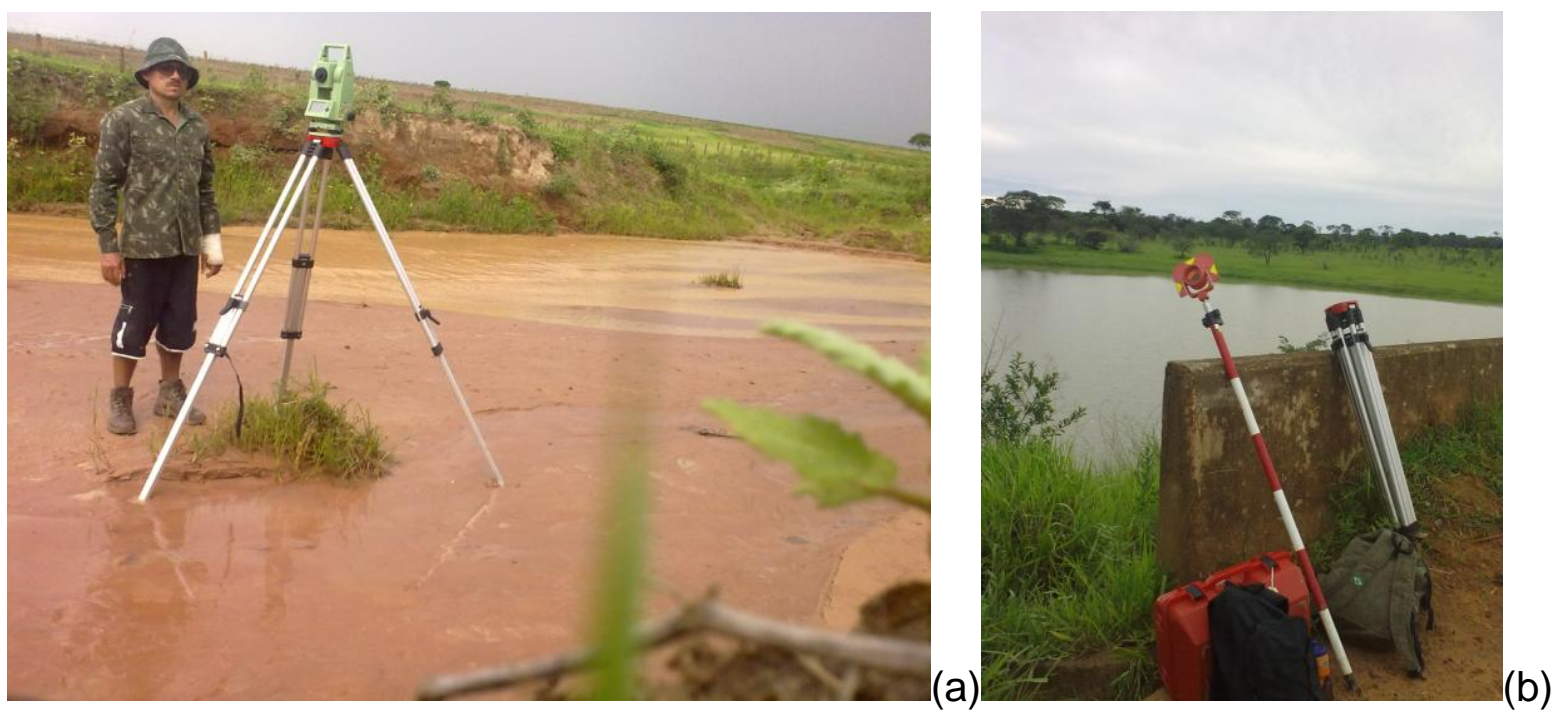

Figura 20 - Equipamentos utilizados no levantamento plani-altimétrico da área de estudo: $a$ = Estação total; b=prisma óptico e tripé (Autor: E. J. Albuquerque Sobrinho).

Estas informações, após seus respectivos tratamentos, foram usadas na elaboração dos mapas, básico e temáticos, do locus de estudo. 


\subsection{Levantamento ecobatimétrico}

Não obstante exista uma certa diversidade instrumental que permita medir a morfologia subaquática dos diferentes ambientes inundados, como por Sensoriamento remoto à laser (THOMA; GUPTA; BAUER, 2001; MILAN; HERITAGE; HETHERINGTON, 2007, HILLDALE \& RAFF, 2008), técnicas geofísicas por GPR e Sísmica (SOUZA, 2006), por imagem de satélite e ecobatimetria (KRUEGER, 1999; MOYLES et al., 2011), adotou-se por meio de ecobatímetro (método geofísico).

Em campo, uso-se o ecobatímetro BATHY 500-MF da Ocean Data cujas coordenadas foram coletadas por um DGPS, modelo GS20 Professional Data Mapper, da Leica Geosystems, acoplado ao ecobatímetro citado, ambos, pertencentes ao Núcleo de Hidrometria do PPG-SEA/USP (fig. 21).

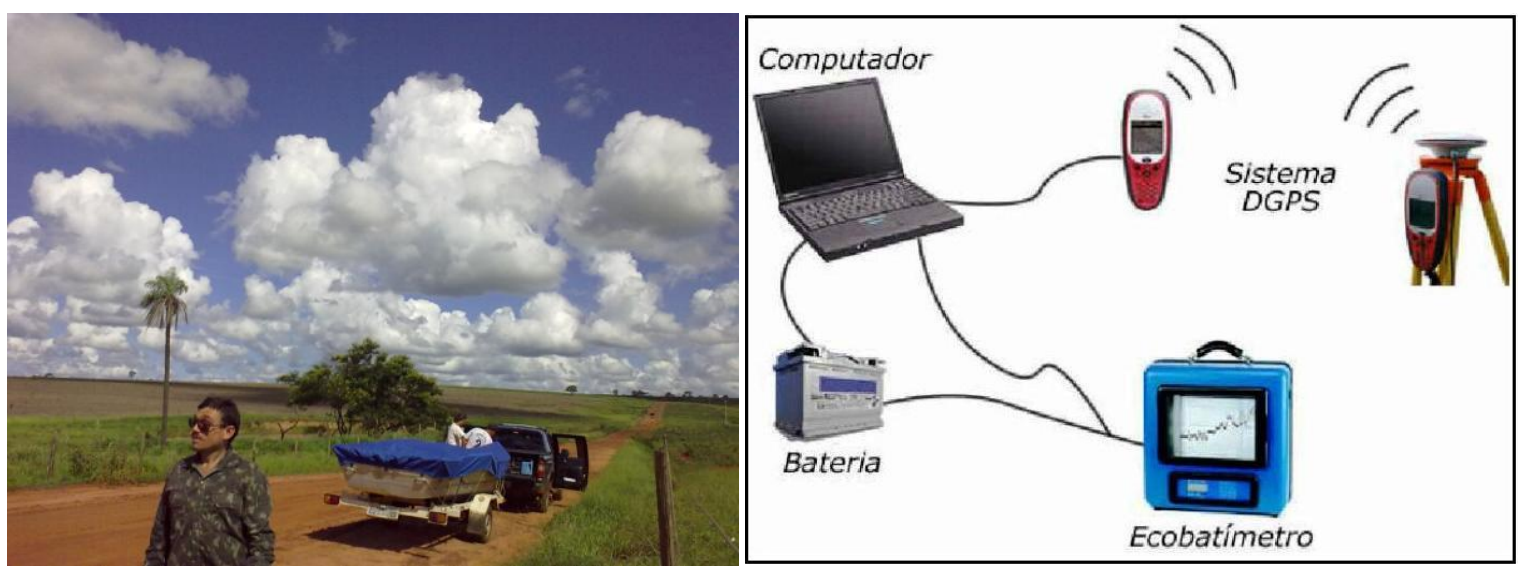

Figura 21 - Preparação dos equipamentos utilizado no levantamento ecobatimétrico no contato córrego/ribeirão das Cruzes (Autor: E. J. Albuquerque Sobrinho).

Para tanto, foram feitas duas seções entre dois pontos distintos, entre as margens do Córrego das Cruzes, sendo uma a leste e outra a oeste, como se observa na figura 22.

A profundidade do local foi calculada, tendo como base à amarração dos dados topográficos com as seções topobatimétricas, de modo a se definir a cota do terreno em relação aos demais pontos/estações topográficas, permitindo-se assim, uma continuidade do terreno na porção seca e inundada. 
Os dados numéricos provenientes deste levantamento encontram-se detalhados no apêndice 2, incluindo ainda as referências (espaciais) da localização da informação.

Com relação à coleta das coordenadas espaciais, a mesma foi feita por receptor de GNSS e antena do sistema de navegação GPS pela técnica "stop and go", cujo sistema de coordenadas adotado foi o geográfico e Datum WGS 84.

Devido ao aumento da profundidade no contato entre o córrego e o ribeirão de mesmo nome, foi necessário modificar a técnica para o levantamento da forma do vale fluvial na citada desembocadura, de modo a se obter o registo contínuo da forma do relevo e seu registro cartográfico, sendo necessário o emprego de ecobatimetria.

Salienta-se que o ecobatímetro coleta três medições, simultâneas, em ângulos distintos, e a atribuição da profundidade é feita pela média destas medidas.

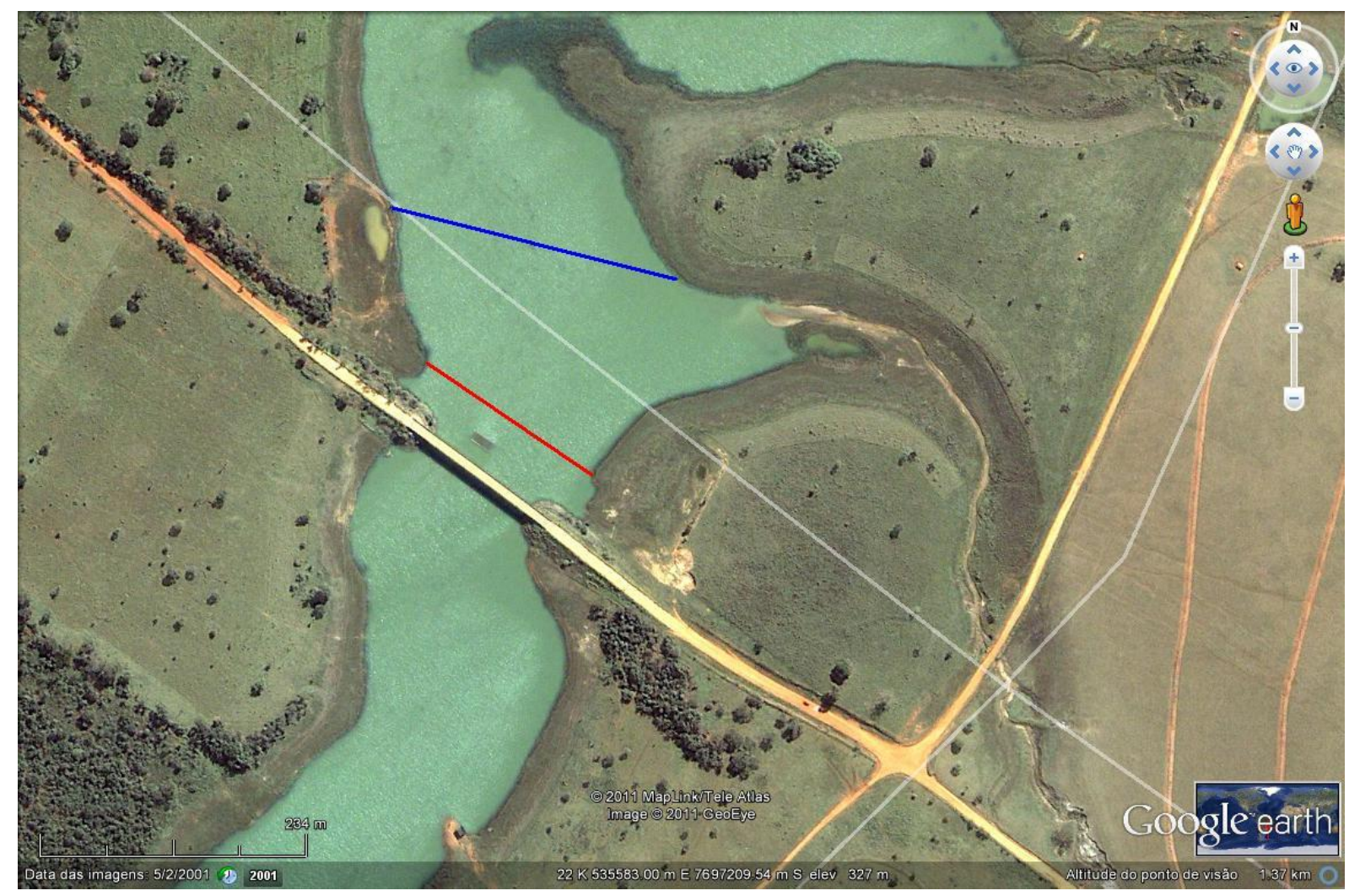

Figura 22 - Distribuição espacial das seções topobatimétricas (Fonte: Google Earth, 2012).

Legenda: linha vermelha = sentido 1-1'; linha azul 2-2'. 


\subsection{Representação das curvas de nível e das isópatas}

Após a realização dos levantamentos topográfico e topobatimétrico na área de estudo, necessitou-se integrar tais geo-dados, oriundos de fontes distintas.

Para integrá-los, os mesmos foram inseridos no software Surfer 32 (fig. 23), incluindo ainda suas respectivas coordenadas espaciais e suas cotas.

Após os dados terem sido lançados neste software, escolheu-se o método de interpolação chamado de mínima curvatura (Minimum Curvature) pois foi o método numérico que melhor apresentou a configuração morfológica do terreno, inclusiva na porção subaquática de maior profundidade.

Em seguida, os dados foram interpolados na forma de isovalores (isóbatas e cotas), seguido do Modelo Digital de Elevação.

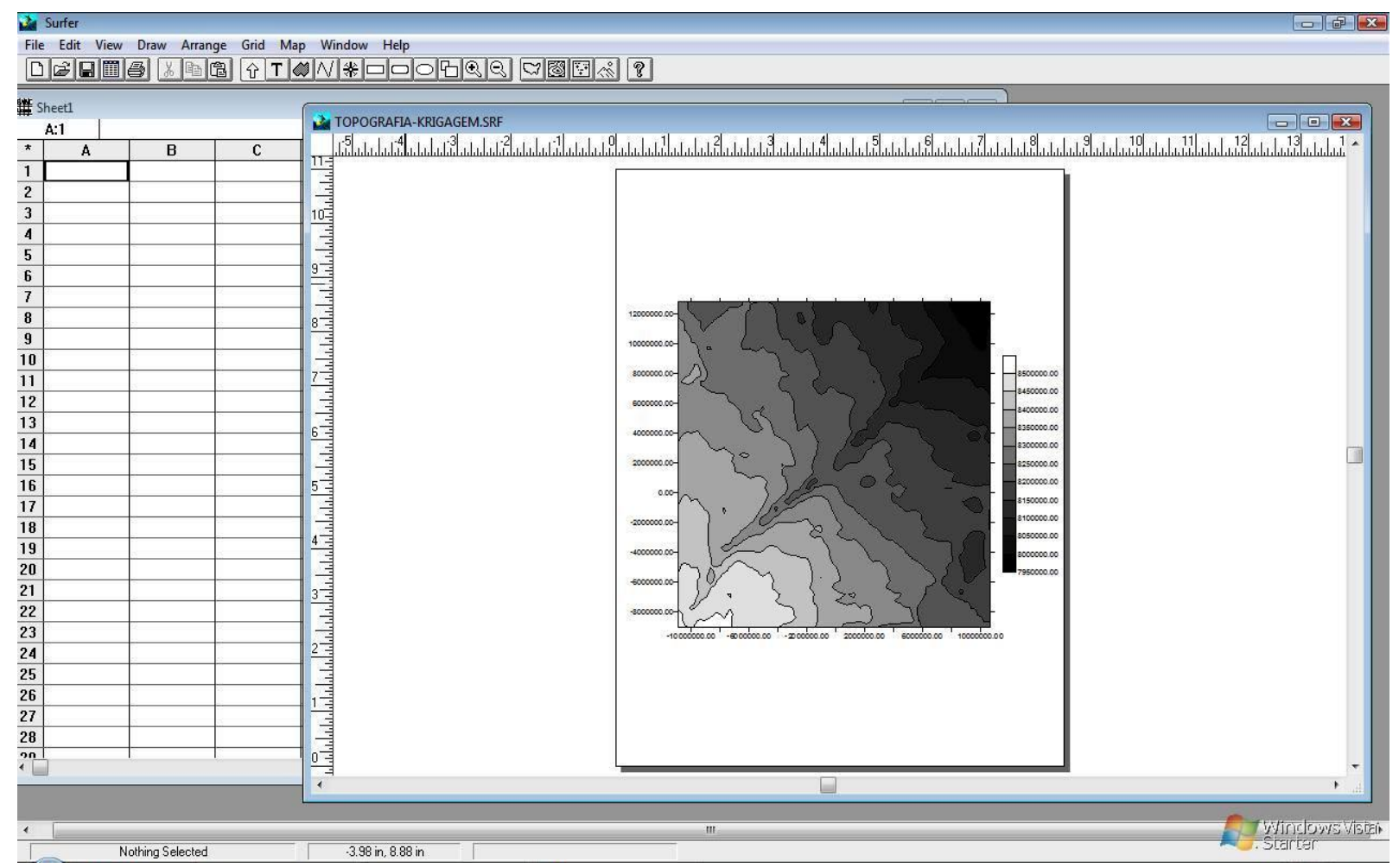

Figura 23 - Software utilizado na elaboração das curvas de nível (Surfer 6.04). 


\subsection{Medição de Vazão por Molinete}

A determinação da vazão do córrego foi feita com uso de molinete. Este instrumento conta o número de voltas durante um intervalo de tempo fixo, neste caso, um minuto, obtendo-se assim uma relação entre a velocidade do fluxo e a rotação desta hélice, como mostra a fórmula de № 1 (CHEVALLIER, 2003).

Equação 1 - Cálculo de vazão por molinete (CHEVALLIER, 2003).

$$
\mathrm{V}=\mathrm{aN}+\mathrm{b}
$$

onde $\mathrm{V}=$ velocidade do fluxo; $\mathrm{N}=$ velocidade de rotação; $\mathrm{e}$ a e b são constantes características da hélice e fornecidas pelo fabricante do equipamento ou determinadas por calibração.

Esta contagem é feita devido à presença de uma hélice em uma de suas extremidades (fig. 24), quando ao entrar em contato com a água em movimento, no sentido do fluxo da água, faz a hélice girar (SOUZA PINTO \& HOLTZ, 1976).

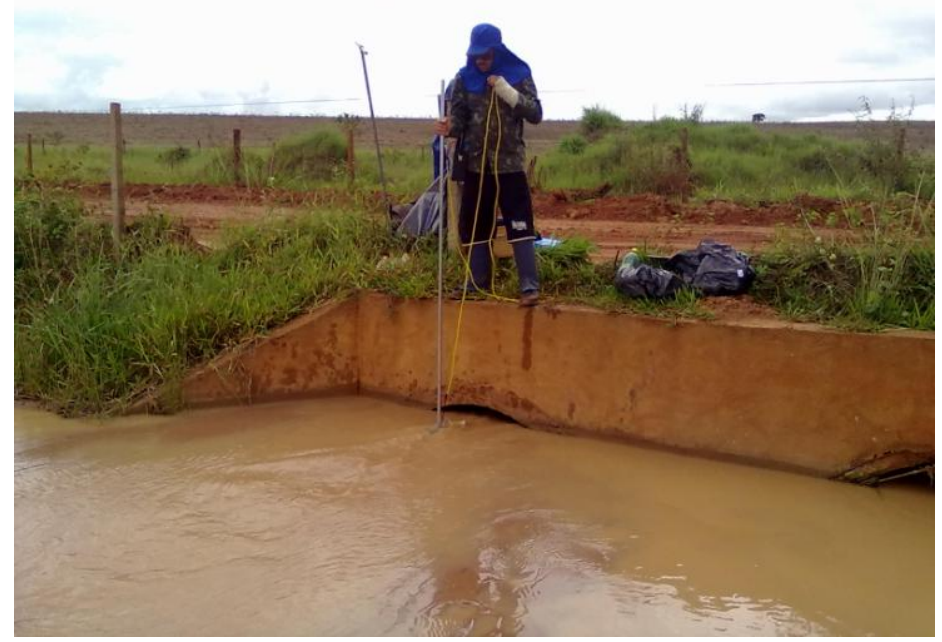

Figura 24 - Molinete usado na medição de vazão (Autor: André Aukar Britschgy de Camargo).

Para isto, foram adotados os seguintes procedimentos em campo: 1) compartimentação da seção da drenagem em um certo número de posições para levantamento do perfil de velocidades; 2) levantamento do perfil de velocidades; cálculo da velocidade média de cada perfil, e; 3) determinação da vazão pelo 
somatório do produto de cada velocidade média por sua área de influência (STUDART, 2003), cujos dados foram calculados no software Exce.

\subsection{Caracterização morfológica dos depósitos consolidados e inconsolidados}

Foram coletadas amostras deformadas das vertentes localizadas no entorno da drenagem relacionados aos materiais superficiais, a cerca de 10 a $20 \mathrm{~cm}$ de profundidade, em relação à superfície, em locais correspondentes ao vale fluvial encaixado (margens esqueda e direita) e a "faixa marginal".

Estes materiais foram armazenados em sacos plásticos e destinados ao laboratório de hidrossedimentologia do Núcleo de Hidrometria do PPG-SEA, para análise de suas propriedades físicas e morfológicas.

Os procedimentos laboratoriais foram feitos segundo o Manual de Descrição e Coleta de Solo no Campo, realizado pela SBCS (1982), cujas variáveis levantadas foram sintetizadas na tabela 23.

Tabela 23 - Propriedades morfológicas dos materiais pedológicos das vertentes (SBCS, 1982).

\begin{tabular}{|c|c|}
\hline Parâmetros & Procedimentos \\
\hline Cor (seca e úmida) & Carta de Munssel (IBGE, 2007) \\
\hline Textura & Táctil-visual (IBGE, 2007) \\
\hline Estrutura & Táctil-visual (IBGE, 2007) \\
\hline Porosidade & Táctil-visual (IBGE, 2007) \\
\hline Consistência & Táctil-visual (IBGE, 2007) \\
\hline Granulometria & NBR 5734 (1989) \& NBR 7181 (1984) \\
\hline Matéria orgânica & TRINDADE (1980) \\
\hline
\end{tabular}

Vale resaltar que o uso dessas propriedades é corrente em levantamento de solos, embora este tipo de estudo não tenha sido realizado na área de estudo devido à natureza dos "solos" do local investigado, pois os mesmos não foram formados pela ação intempérica sobre rocha pré-existente, já que são depósitos sedimentares pedogenizados. 


\subsection{Caracterização granulométrica e textural da área de estudo}

Foram coletadas 32 amostras deformadas ao longo da área de estudo para caracterização granulométrica e textural, após isso, tais materiais foram embalados em sacos plásticos e destinados aos laboratórios de Hidrossedimentologia, do Núcleo de Hidrometria e de Mecânica dos Solos, do Departamento de Geotecnia (EESC-USP).

Com relação à coleta, adotou-se o espaçamento diferencial entre elas, de modo a representá-las cartograficamente na técnica de Detalhamento Progressivo, cujo procedimento computacional encontra-se no tópico 6.11.

Quanto aos procedimentos laboratoriais relacionados à execução da granulometria, os mesmos foram feitos segundo as normas técnicas NBR 5734 (1989) e NBR 7181 (1984):

- Estas amostras foram postas para secar em estufa (TFSE) por 24h a temperatura de $105^{\circ} \mathrm{C}$ e em seguida foram postas para secarem no dissecador;

- As amostras foram pesadas e em seguida foram postas no agitador mecânico por 15h, onde as peneiras estavam distribuidas grano-decrescentes;

- Pesou-se o conteúdo retido no interior de cada peneira, e;

- Traçou-se a curva granulométrica das amostras.

Vale salientar que devido a baixa concentração de argila retida, cuja participação foi muito baixa, optou-se em não realizar a granulometria desta fração, já que a fração areia e suas variações predominaram neste ensaio.

\subsection{Teor de matéria orgânica}

Com base nas 32 amostras comentadas no tópico 6.7 , definiu-se o percentual de materia orgânica de cada amostra, desde aquelas que se encontravam no interior do canal do Córrego das Cruzes quanto em suas margens (direita e esquerda). Após o transporte das mesmas para as dependências do Núcleo de Hidrometria (EESCP/USP/PPG-SEA), foram realizados os seguintes procedimentos laboratoriais 
com base em Trindade (1980), a fim de definir a quantidade de matéria orgânica dos 6“solos" da área de estudo (ver figura 25 e 27).
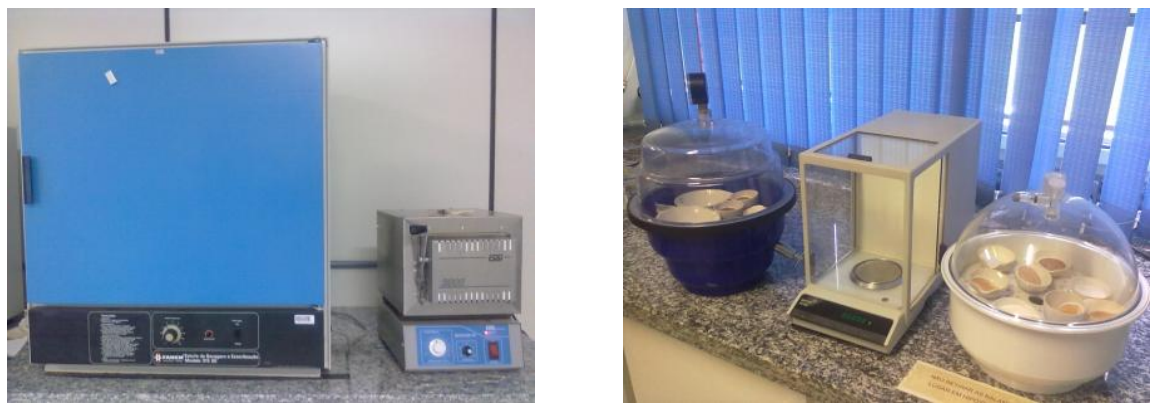

Figura 25 - Equipamentos utilizados na definição da quantidade de materia orgânica dos solos (Autor: E. J. Albuquerque Sobrinho).

A distribuição espacial dos pontos de coleta pode ser visualizada na figura 26.

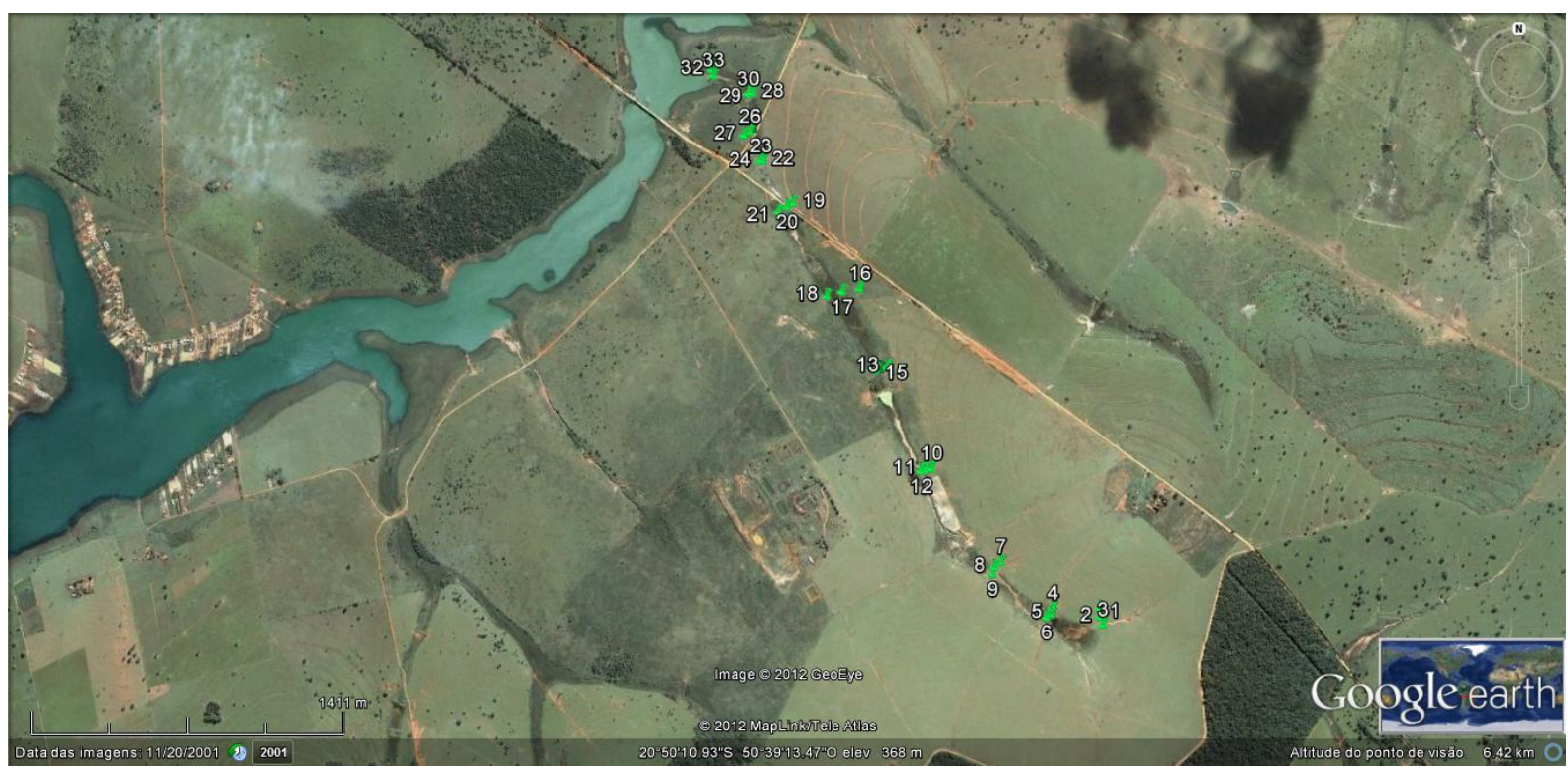

Figura 26 - Localização dos pontos de amostragem do teor de matéria orgânica dos materiais geológicos da área de estudo (Fonte: Google Earth, 2012).

Sendo assim, foram realizados as seguintes atividades laboratoriais:

- $\quad$ Colocou-se os cadinhos na mufla a $500^{\circ} \mathrm{C}$ por 1 hora, a fim de calcinar);

- $\quad$ Espera do resfriamento dos cadinhos, seguido de pesagem dos mesmos;

- $\quad$ Anotação dos pesos do cadinho após a mufla (peso 0);

- Colocou-se $5 \mathrm{~g}$ do material coletado em campo por amostra, em cada cadinhos, seguido de secagem em estufa a $103^{\circ} \mathrm{C}$ por $24 \mathrm{~h}$; 
- $\quad$ Espera do resfriamento das amostras, em dissecador, seguido de nova pesagem, cujo valor corresponde ao peso 1 ;

- Colocou-se os mesmos cadinhos com as amostras no interior da mufla, à temperatura de $550^{\circ} \mathrm{C}$ por 1 hora;

- $\quad$ Após este tempo, a espera do resfriamento das mesmas no dissecador foi seguida das respectivas pesagens (peso 2).

\subsection{Sólidos em Suspensos Totais}

Para definir o percentual de sólidos em suspensão, coletou-se $500 \mathrm{ml}$ de água por amostra, em duplicatas, totalizando 30 amostras (ver figura 27), onde as mesmas foram captadas ao longo da drenagem, desde a nascente até a desembocadura.

A coleta foi realizada em duas campanhas distintas, sendo uma no período chuvoso (janeiro) e outro na estiagem (julho).

Após a coleta, estes materiais foram transportados e armazenados no laboratório de hidrossedimentologia do Núcleo de Hidrometria (PPG-SEA) para definição do teor de sólidos em suspensão total pela técnica de filtração (foram usados Microfiltros de fibra de vidro com diâmetro de $47 \mathrm{~mm}$ ). 


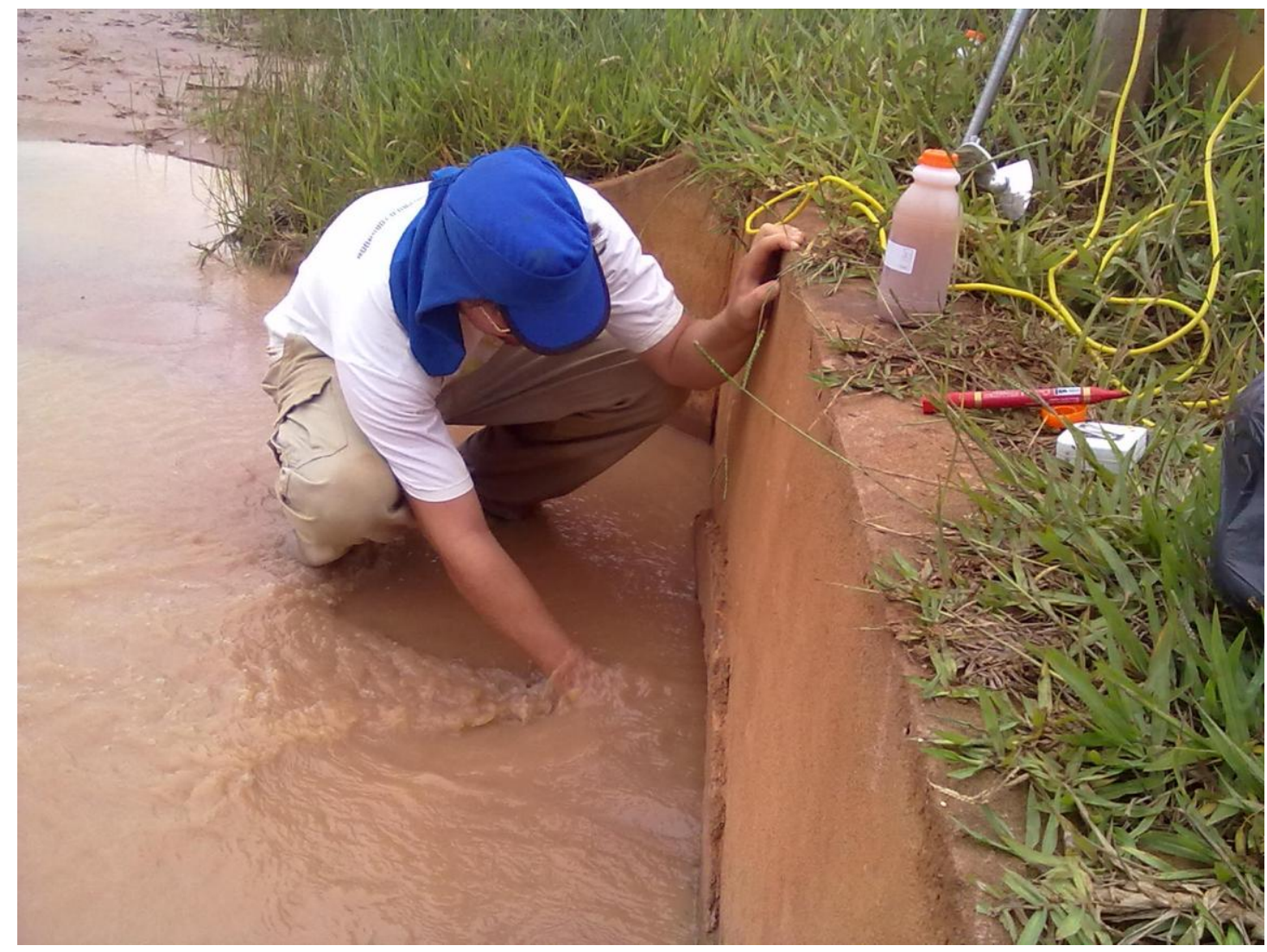

Figura 27 - Coleta de amostra em duplicata para definição do teor de sólidos em suspensão (Autor: E. J. Albuquerque Sobrinho).

No entanto, devido à baixa profundidade e a largura do leito menor ser pequena, optou-se em coletar no centro do canal, por se apresentar mais profundidade, em relação ao restante da drenagem (valor máximo encontrado foi inferior a $30 \mathrm{~cm}$ de lâmina d'água, em uma área onde aflora um arenito fino, com presença de mica), desconsiderando os locais, cuja profundidade observada era inferior a $10 \mathrm{~cm}$.

Para tanto, foram realizados os seguintes procedimentos laboratoriais:

- Os Microfiltros de fibra de vidro usados no processo de filtração foram levados à mufla para serem calcinados, permanecendo em seu interior por 1 hora após atingir a temperatura de $500 \mathrm{C}^{\circ}$;

- Após este período, os mesmos foram retirados para resfriarem, onde em seguida, pesou-se tais filtros a fim de definir o peso inicial (Peso 0);

- Após o resfriamento destes filtros, os mesmo foram pesados (P0) em balança de precisão; 
- $\quad$ Em seguida, estes filtros foram acoplados a um filtro, onde cada amostra foi filtrada separadamente e cujo volume de água por garafa foi anotado;

- $\quad$ O material retido por filtro foi levado à estufa, a $105^{\circ} \mathrm{C}$ por 24 horas e após este prazo, seguido de seu resfriamento, pós estufa, foi pesado (Peso 1), como mostra a figura 26 ;

- Concluída a pesagem anterior, cada filtro foi destinado à mufla, a temperatura de $550^{\circ} \mathrm{C}$ por 1 hora e posteriormente, pesou-se a amostra (peso 2).

Ao final, calculou-se o peso total da amostra (agregados+matéria orgânica) e o teor de matéria orgânica (peso total - peso dos agregados).

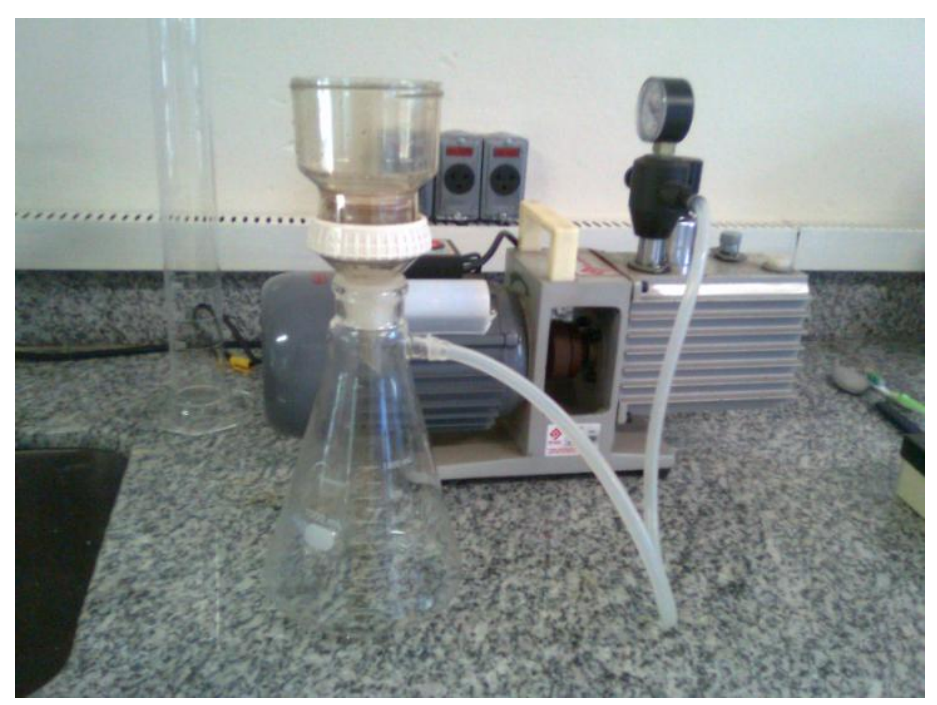

Figura 28 - Equipamento utilizado no processo de filtragem das amostras de campo (Autor: E. J. Albuquerque Sobrinho).

\subsection{Medição de infiltração do solo}

A medição da infiltração de água no solo foi utilizado em campo através de um infiltrômetro, conforme modelo sugerido por GUERRA (2001), o qual consiste em um tubo de PVC de $15 \mathrm{~cm}$ de altura por $10 \mathrm{~cm}$ de diâmetro (com uma régua graduada na parte interna do cano) onde os $5 \mathrm{~cm}$ iniciais do mesmo é introduzido no interior do solo e preenchido com água e mediu-se o tempo de rebaixamento da água no interior do infiltrômetro (ver fig. 29). 
Foram marcadas suas respectivas profundidades nos seguintes tempos: 30 segundos do início do ensaio com tubo preenchido por água; 1 minuto; 1.30 minutos e 2 minutos e em seguida a cada um minuto, totalizando em 30minutos de execução (GUERRA, 2001).

Vale ressaltar que a cada vez que a profundidade atinge a marca de $5 \mathrm{~cm}$ na régua do infiltrômetro, marca-se o tempo que isso aconteceu e completa-se o tubo com água e continue marcando a profundidade a cada minuto e o cálculo do volume de água é feito pela fórmula $\pi R^{2} \times h$ onde $R=$ Raio do tubo de PVC e $h=$ altura de água infiltrada durante $o$ experimento, a cada tempo.

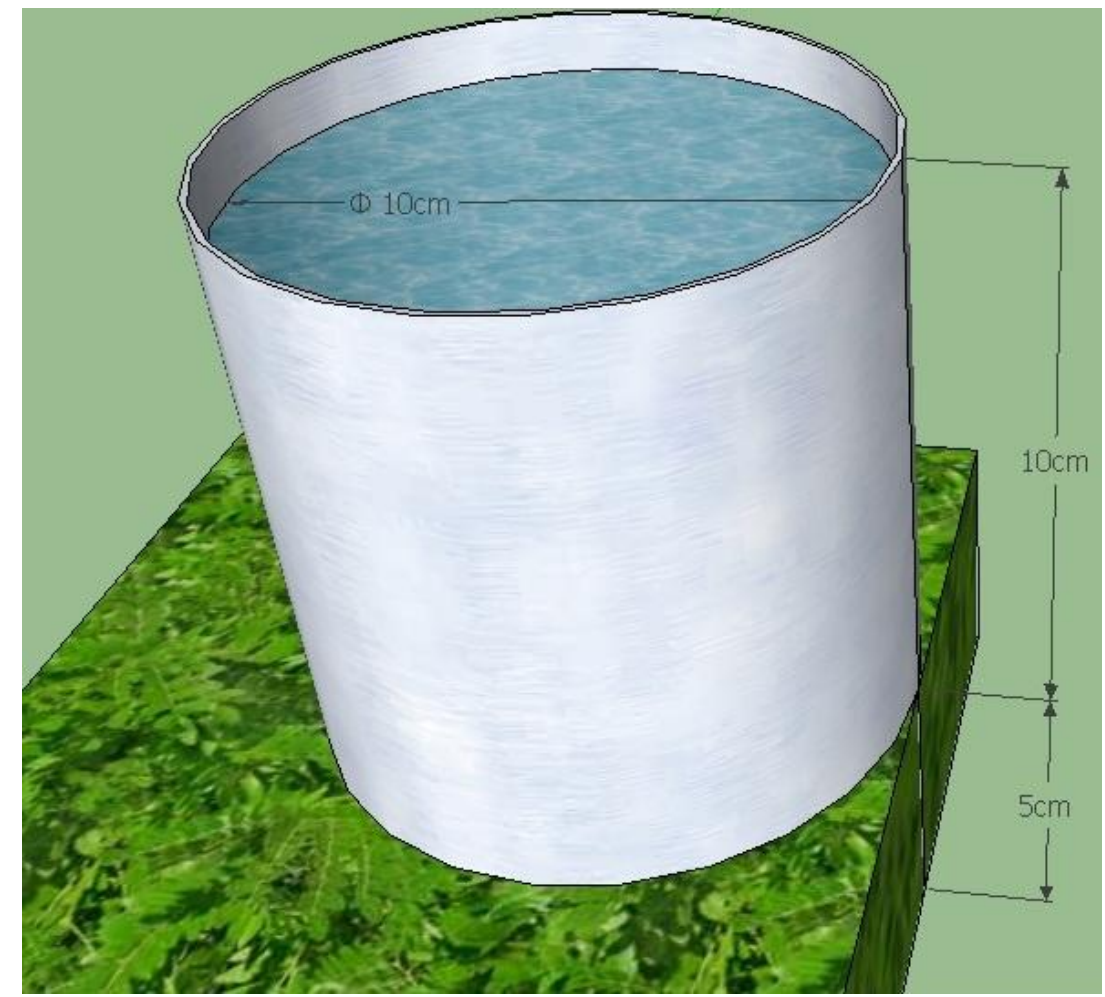

Figura 29 - Modelo de infiltrômetro usado na área de estudo (adaptado de GUERRA, 2001).

Para isto, foram realizados nove ensaios de infiltração, em pontos distintos da área de estudo, onde os falores obtidos foram usados, também, no sistema de avaliação em proposição; 


\subsection{Mapeamento Geológico-geotécnico por Detalhamento Progressivo}

A representação cartográfica da área de estudo e dos elementos geológicos levantados foram representados segundo a norma técnica NBR 13441 (1995).

Estes documentos representam feições, elementos, informações oriundas de um determinado segmento da superfície da terra, por exemplo, cujos dados distribuem-se latitudinalmente e longitudinalmente.

Devido à morfologia da área de estudo, cujo espaço dificulta à representação cartográfica, já que é um local, predominantimente estreito, em relação ao seu cumprimento, optou-se pela técnica de detalhamento progressivo.

De acordo com Cerri et al. (1996) apud Zaine (2000) este "método" consiste na adoção de diferentes escalas de abordagens para a elaboração de documento cartográfico, a partir de três estapas distintas, que segundo o citado autor, consiste em: 1) etapa geral (detalhamento feito do geral para o específico); 2) etapa intermediária (detalhamento na caracterização do meio físico, além da identificação de problemas geológico-geotécnicos eventuais), e; 3) etapa de detalhamento (a partir da identificação dos problemas de natureza geológica levantados na fase anterior, são selecionados os locias para estudos mais específicos, podendo envolver na confecção de documentos cartográficos de detalhe).

A aplicação desta técnica, por exemplo, foi feita por Cerri et al. (1996) e por Zaine (2000), em escala de representação variada, sendo isto de suma importância, já que a largura do riacho em ênfase neste trabalho é desproporcional ao comprimento do mesmo.

Neste intuito, foram identificados e registrados os contatos litológicos ao longo da área de investigação, seguido de coleta de amostras para análise laboratorial dos sedimentos provenientes das margens e do interior da drenagem e cujas coordenadas espaciais foram obtidas por meio de GPS de mão, no método "stop and go", como comentado nos tópicos 6.5 a 6.10 .

Após a elaboração do mapa topográfico, seguido dos dados geológicos, compartimentou-se a área de estudo em sete seções distintas, a fim de executar um mapeamento de detalhe, na escala 1: 1.000 condizentes, também com o espaço 
amostrado usado na aplicação das técnicas: Protocolo de Avaliação de Rápidos (EPA, 1987) e do sistema de avaliação geoambiental em questão.

Estes documentos cartográficos foram realizados no software AutoCad Map 2012 Educational Version e interpolação da curva de isovalores (método mínima curvatura), no software Surfer 6.04 (ver tópico 6.4).

Vale salientar que os procedimentos para análise dos materiais geológicos foram feitos segundo as normas técnicas NBR 6502 (1995) e NBR 7181 (1984). 


\section{AVALIAÇÃO DA ÁREA DE ESTUDO POR TÉCNICAS DISTINTAS}

\subsection{Abordagem geológico-geotécnico de avaliação ambiental em ambiente fluvial}

Visando investigar o "locus" de estudo sob técnicas distintas, dicidiu-se em dividir este objetivo, cujas variáveis de caráter geológico-geotécnicas foram aglutinadas no mesmo tópico, a fim de facilitar a interpretação durante à análise dos resultados, como segue os subtópicos de 7.1.1 a 7.4.

\subsubsection{Caracterização geológica}

Ao avaliar os materiais geológicos coletados no interior da área de estudo, percebeu-se que se trata de um ambiente com elevada concentração da fração areia com espessura variada (de $30 \mathrm{~cm}$ à $1 \mathrm{~m}$ ), cujas camadas geológicas mergulham discordantemente, em relação ao sentido de mergulho da drenagem.

Nas camadas mais profundas (base) da área que corresponde ao leito menor e maior do Córrego das Cruzes, observou-se a presença de dois afloramentos rochosos bem distintos: 1) arenitos rico em quartzo e óxidos de ferros, na forma de incrustações, e; 2) arenito micácio de cor acinzantada, como visto anteriormente no mapa 1.

Por volta do final da primeira década do século XXI, o local em abordagem já teve dois pequenos reservatórios, que se romperam devido à grande volume de chuva, conforme comentado por um dos trabalhadores da Fazenda Santa Amélia.

Ao analisar os locais onde existiam dois antigos reservatórios, percebeu-se que nestas localidades o desnível é de aproximadamente $3 \mathrm{~m}$ de altura entre o topo a base das margens, cujas paredes do vale encaixado tinham inclinação variando de $15^{\circ}$ a $70^{\circ}$ (margem direita) e de $40^{\circ}$ a $79^{\circ}$ (margem direita), em um local rico em sedimentos areno-siltosos de coloração cinza, com presença de argila, como se observa na figura 30 . 


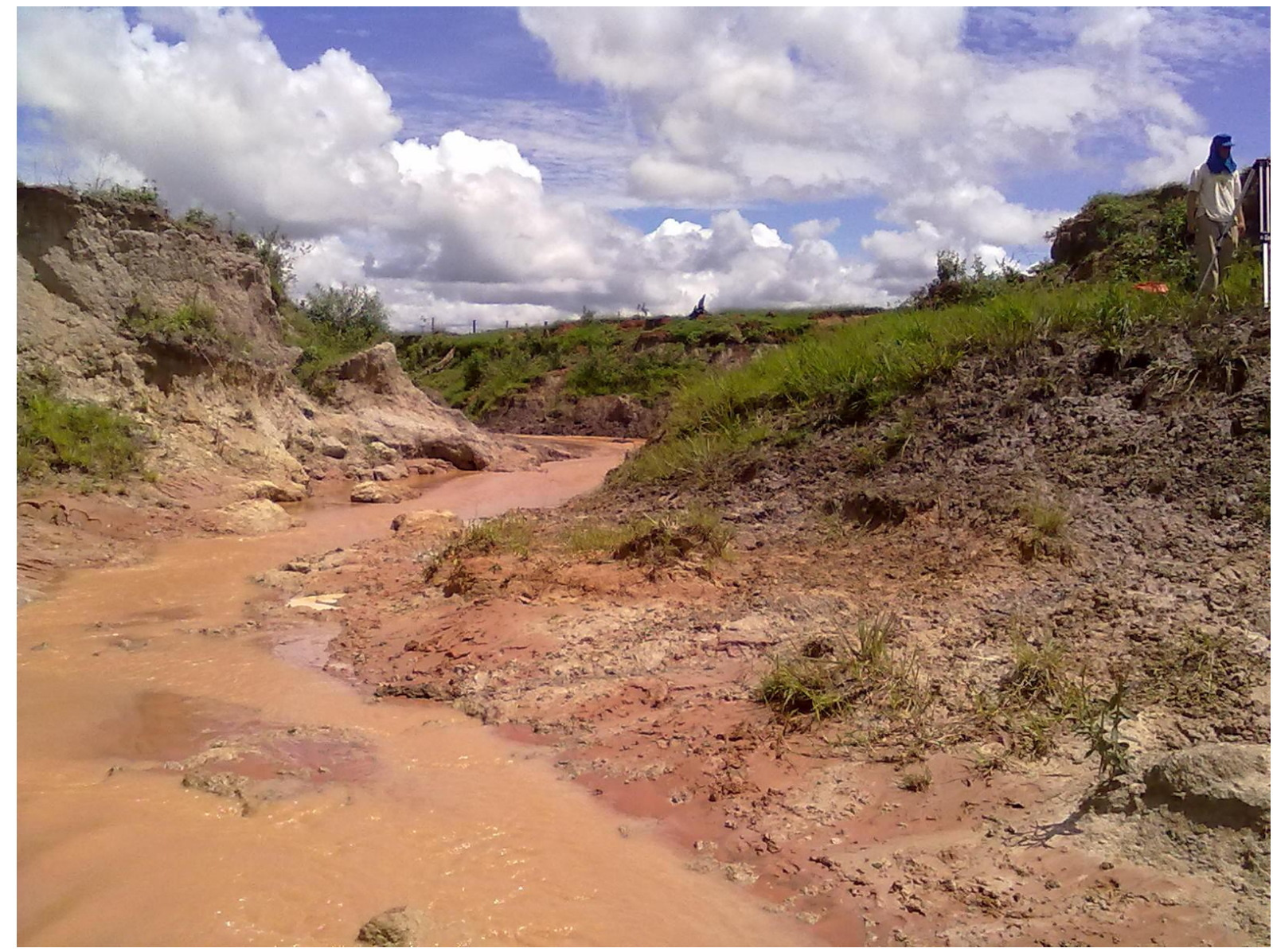

Figura 30 - Localização do antigo reservatório que se rompeu no interior do Córrego das Cruzes (Autor: E. J. Albuquerque Sobrinho).

Nestas localidades, foram observadas fortes feições erosivas, provavelmente em decorrência da ruptura destas barragens, mas a lâmina dágua oriunda da massa aquosa barrada, ao ter seu núcleo rompido, provavelmente, contribuiu para a aceleração degradacionais destes pontos, como observado na figura 31 .

No segundo reservatório, percebeu-se que no citado local, a base do canal apresenta um desnível, em relação às suas márgens, superiores a $45^{\circ}$ de inclinação, em processo de degradação em função do pisoteio do gado à época, embora esta atividade econômica (pecuária) tenha sido transferida para outras fazendas da região.

Foi constatado ainda a ocorrência de um afloramento arenítica rico em micas, que ocorre no interior do terreno, estando o mesmo alterado (solo residual jovem). 
Nesta localidade, o gado usava a área para ter acesso à lâmida d'água, que neste deslocamento, foram observados "in situ", feições lineares, solapamento basal, bem como, solifluxão de parte das vertentes.

As condições topográficas e geológico-geotécnicas favoreceram a degradação do terreno, por serem além pobres em matéria orgânica, apresentam variação de permeabilidade dos solos (permeável na desembocadura e impermeável em alguns segmentos usados como rota pelo gado).

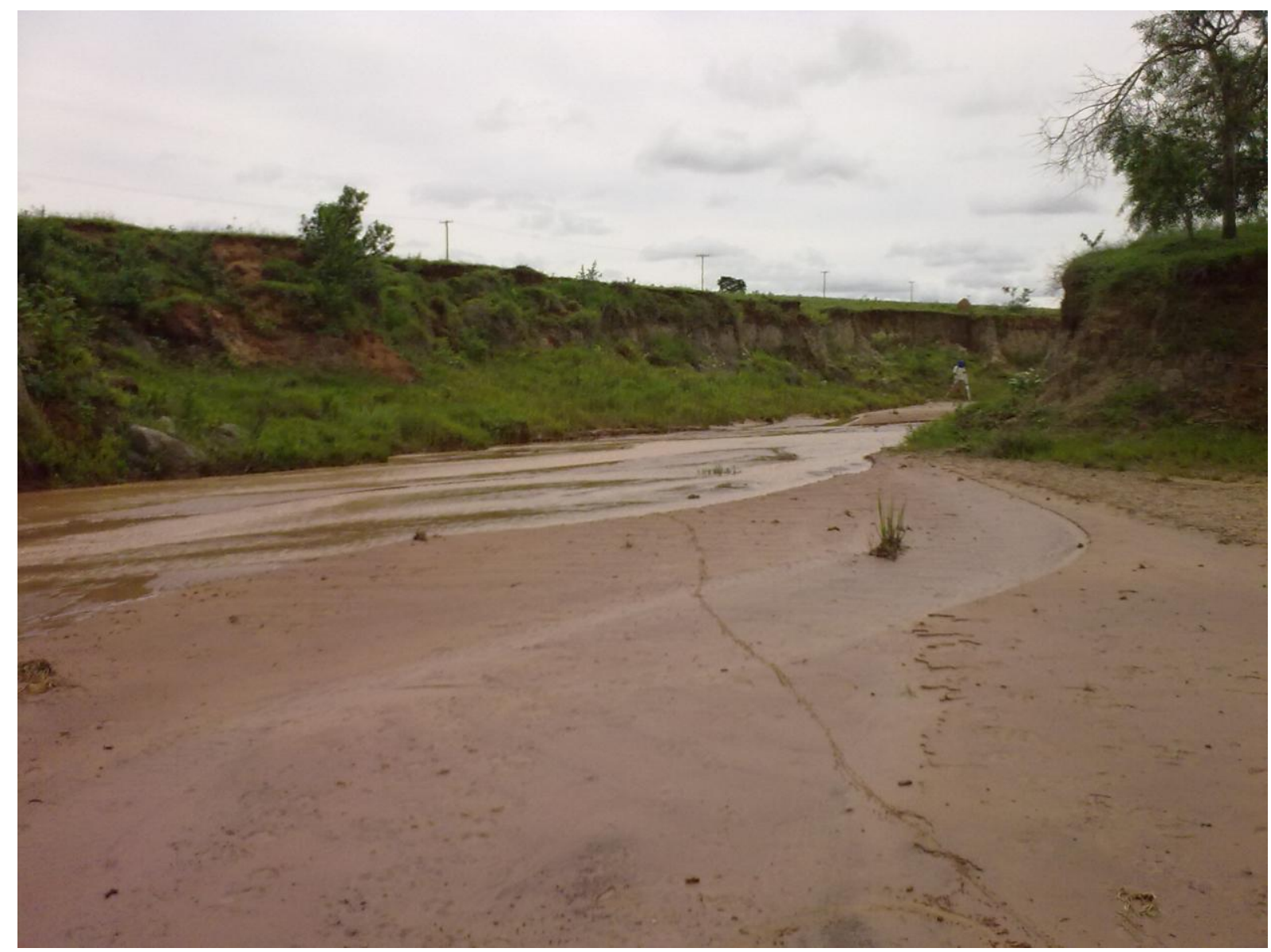

Figura 31 - Vista do segundo reservatório que se rompeu ao longo do Córrego das Cruzes (Autor: E. J. Albuquerque Sobrinho). 


\subsubsection{Caracterização pedológica}

Apesar dos materiais geológicos da área de estudo terem sido formados pela consolidação de materiais disponibilizados, os mesmos não poderiam ser denominados de solos, posto que estes são formados pela decomposição/alteração de uma rocha pré-existente em solos.

Mesmo assim, adotou-se o uso das propriedades físicas e morfológicas dos solos, na avaliação pedológica destes depósitos, conforme apresentado nos tópicos 4.3, 6.6, 6.7 e 6.8 .

Após a coleta de campo dos diferentes materiais geológicos, conforme procedimentos comentados anteriormente (ver tópico 6.6), onde foram levantadas diferentes propriedades morfológicas dos solos, em seus diferentes estados físicos (seca, úmida e molhada), quando assim requerido pela investigação citada, chegouse a um ao seguinte resultado (ver tabela 24):

- A tonalidade de cores das amostras de campo, tanto estando secos quanto umedecidos variam entre sí, embora tenham apresentado uma certa gradação indicando um paleoambiente tendendo ao clima com variação de temperatura e umidade ao longo do tempo.

- A textura do solo é predominantemente arenosa, apesar das amostras 7, 14, $15,16,20,21$ e 35 foram classificadas como areno-argilosas, apesar de que a amostra 35 ter em seu interior materiais de fração mais grosseira, como seixos e cascalhos com faces sub-angulares, onde foi coletada em um segmento do cana encaixado no interior de uma rocha sedimentar rica em quartzo e presença de material micáceo, que apresenta coerência (resistência ao golpeamento do martelo geológico) do tipo C2 (coerente).

- $\quad$ Por outro lado, os materiais com textura areno-siltosos foram observados nas amostras $11,23,24$ e 25 , ao passo que as silto-argilosa foram detectados nas amostroas 31, 32, 33 e 34 .

- $\quad$ Com relação à estrutura, observou-se que a mesma variou ao longo da área de estudo, com relação à sua forma e ao tamanho, como observado na tabela 24 . 
Como é possível observar, a forma da estrutura não corroborou com a testura do solo, indicando que o pisoteio do gado alterou a estrutura do solo.

- Devido à predominância da fração arenosa, estes materiais não apresentaram consistência plástica, embora nas proximidades da desembocadura, os materiais contendo silte e argila tenham ocorridom com presença da fração argila, provavelmente são oriundo de outras porções limítofres da Ribeirão das Cruzes.

- Estes materiais apresentam em sua constituição forte presença de conteúdo na fração areia, variando de muito fina a grossa, embora silte e argila ocorrem de forma inespressiva, incluindo ainda, seixos e cascalhos, conforme exposto no apêndice 3. 
Tabela 24 - Variação das propriedades morfológicas dos diferentes materiais geológicos da área de estudo.

\begin{tabular}{|c|c|c|c|c|c|c|c|c|}
\hline \multirow{2}{*}{$\begin{array}{c}\mathrm{N}^{\circ} \\
\text { amostra }\end{array}$} & \multicolumn{2}{|c|}{ Cor } & \multirow[b]{2}{*}{ Textura } & \multirow[b]{2}{*}{ Estrutura } & \multirow[b]{2}{*}{ Porosidade } & \multicolumn{3}{|c|}{ Consistência } \\
\hline & Seca & Úmida & & & & Seca & Úmida & Molhada \\
\hline 1 & $\begin{array}{l}\text { Bruno muito } \\
\text { claro- } \\
\text { acinzentado }\end{array}$ & $\begin{array}{l}\text { Bruno- } \\
\text { amarelado }\end{array}$ & Arenosa & Sem estrutura & Pequena & Macia & Macia & Não plástica \\
\hline 2 & $\begin{array}{l}\text { Amarelo- } \\
\text { brunado }\end{array}$ & $\begin{array}{c}\text { Bruno- } \\
\text { acinzentado }\end{array}$ & Arenosa & $\begin{array}{c}\text { Bloco subangular de } \\
\text { tamanho variado }\end{array}$ & Pequena & $\begin{array}{l}\text { Pouco a } \\
\text { muito duro }\end{array}$ & Macia & Não plástica \\
\hline 3 & $\begin{array}{c}\text { Amarelo- } \\
\text { avermelhado }\end{array}$ & $\begin{array}{c}\text { Cinzento- } \\
\text { escuro }\end{array}$ & Arenosa & Bloco subangular & Pequena & Macia & Macia & Não plástica \\
\hline 4 & $\begin{array}{c}\text { Bruno- } \\
\text { avermelhado }\end{array}$ & $\begin{array}{c}\text { Bruno- } \\
\text { avermelhado }\end{array}$ & Arenosa & $\begin{array}{l}\text { Bloco subangular de } \\
\text { tamanho variado }\end{array}$ & Muito pequena & Solta & Solta & Não plástica \\
\hline 5 & $\begin{array}{c}\text { Amarelo- } \\
\text { avermelhado }\end{array}$ & Bruno & Arenosa & $\begin{array}{l}\text { Bloco subangular de } \\
\text { tamanho variado }\end{array}$ & Pequena & Macia & Solta & Não plástica \\
\hline 6 & $\begin{array}{l}\text { Cinzento- } \\
\text { claro }\end{array}$ & Bruno-claro & Arenosa & $\begin{array}{l}\text { Bloco subangular de } \\
\text { tamanho variado }\end{array}$ & $\begin{array}{c}\text { Muito pequena a } \\
\text { pequena }\end{array}$ & Solta a Macia & Solta & Não plástica \\
\hline 7 & $\begin{array}{c}\text { Amarelo- } \\
\text { claro- } \\
\text { acinzentado }\end{array}$ & $\begin{array}{c}\text { Vermelho- } \\
\text { claro- } \\
\text { acinzentado }\end{array}$ & $\begin{array}{l}\text { Areno- } \\
\text { argilosa }\end{array}$ & $\begin{array}{l}\text { Bloco subangular de } \\
\text { tamanho variado }\end{array}$ & $\begin{array}{c}\text { Muito pequena a } \\
\text { pequena }\end{array}$ & $\begin{array}{c}\text { Macia a } \\
\text { ligeiramente } \\
\text { Dura }\end{array}$ & Muito friável & $\begin{array}{l}\text { Ligeiramente } \\
\text { plástica }\end{array}$ \\
\hline 8 & Bruno-claro & $\begin{array}{c}\text { Bruno- } \\
\text { acinzentado }\end{array}$ & Arenosa & Sem estrutura & Pequena & Macia & Macia & Não plástica \\
\hline 9 & $\begin{array}{c}\text { Bruno- } \\
\text { amarelado- } \\
\text { claro }\end{array}$ & $\begin{array}{c}\text { Bruno- } \\
\text { amarelado }\end{array}$ & Arenosa & Bloco subangular & Pequena & Macia & Macia & Não plástica \\
\hline 10 & $\begin{array}{c}\text { Cinzento- } \\
\text { claro }\end{array}$ & Cinzento-claro & Arenosa & Prismático & Pequena & Dura & Macia & Não plástica \\
\hline 11 & \begin{tabular}{|c|} 
Bruno- \\
avermelhado- \\
claro
\end{tabular} & $\begin{array}{c}\text { Bruno- } \\
\text { amarelado }\end{array}$ & Areno-siltosa & $\begin{array}{l}\text { Bloco subangular de } \\
\text { tamanho variado }\end{array}$ & Pequena & Macia & Muito friável & Não pegajosa \\
\hline
\end{tabular}


Continuação da tabela 24.

\begin{tabular}{|c|c|c|c|c|c|c|c|c|}
\hline \multirow{2}{*}{$\begin{array}{c}\mathbf{N}^{\circ} \\
\text { amostra }\end{array}$} & \multicolumn{2}{|c|}{ Cor } & \multirow[b]{2}{*}{ Textura } & \multirow[b]{2}{*}{ Estrutura } & \multirow[b]{2}{*}{ Porosidade } & \multicolumn{3}{|c|}{ Consistência } \\
\hline & Seca & Úmida & & & & Seca & Úmida & Molhada \\
\hline 12 & $\begin{array}{c}\text { Cinzento- } \\
\text { avermelhado }\end{array}$ & Cinzento & Arenosa & $\begin{array}{l}\text { Bloco subangular de } \\
\text { tamanho variado }\end{array}$ & Muito Pequena & Pouco dura & Macia & Não plástica \\
\hline 13 & $\begin{array}{l}\text { Bruno-claro- } \\
\text { acinzentado }\end{array}$ & $\begin{array}{c}\text { Bruno- } \\
\text { acinzentado }\end{array}$ & Arenosa & $\begin{array}{l}\text { Bloco subangular de } \\
\text { tamanho pequeno }\end{array}$ & Pequena & $\begin{array}{l}\text { Pouco dura- } \\
\text { muito dura }\end{array}$ & Macia & Não plástica \\
\hline 14 & \begin{tabular}{|c|} 
Cinzento- \\
brunado-claro
\end{tabular} & Cinzento & $\begin{array}{l}\text { Areno- } \\
\text { argilosa }\end{array}$ & Laminar Maciça & Muito Pequena & Muito dura & Dura & $\begin{array}{l}\text { Pouco } \\
\text { plastica }\end{array}$ \\
\hline 15 & $\begin{array}{l}\text { Bruno-claro- } \\
\text { acinzentado }\end{array}$ & Bruno & $\begin{array}{l}\text { Areno- } \\
\text { argilosa }\end{array}$ & $\begin{array}{c}\text { Colunar de tamanho } \\
\text { variado }\end{array}$ & Muito Pequena & Muito dura & Dura & Plastica \\
\hline 16 & Bruno-claro & $\begin{array}{l}\text { Vermelho- } \\
\text { escuro }\end{array}$ & $\begin{array}{l}\text { Areno- } \\
\text { argilosa }\end{array}$ & $\begin{array}{c}\text { Laminar de tamanho } \\
\text { variado }\end{array}$ & Pequena a Media & $\begin{array}{l}\text { Ligeiramente } \\
\text { dura }\end{array}$ & Solta & Não plástica \\
\hline 17 & $\begin{array}{l}\text { Bruno muito } \\
\text { claro- } \\
\text { acinzentado }\end{array}$ & $\begin{array}{c}\text { Bruno- } \\
\text { amarelado- } \\
\text { escuro }\end{array}$ & Arenosa & Sem estrutura & Muito Pequena & Macia & Macia & Não plástica \\
\hline 18 & $\begin{array}{l}\text { Bruno- } \\
\text { amarelado- } \\
\text { escuro }\end{array}$ & $\begin{array}{l}\text { Bruno- } \\
\text { avermelhado- } \\
\text { claro }\end{array}$ & Arenosa & Granular Pequeno & Pequena & Solta & Solta & Não plástica \\
\hline 19 & Branco & $\begin{array}{c}\text { Cinzento- } \\
\text { brunado-claro }\end{array}$ & Arenosa & Colunar & Pequena & Macia & Macia & Não plástica \\
\hline 20 & $\begin{array}{l}\text { Bruno muito } \\
\text { claro- } \\
\text { acinzentado }\end{array}$ & $\begin{array}{c}\text { Bruno- } \\
\text { amarelado- } \\
\text { escuro }\end{array}$ & $\begin{array}{l}\text { Areno- } \\
\text { argilosa }\end{array}$ & $\begin{array}{c}\text { Laminar de tamanho } \\
\text { variado }\end{array}$ & Pequena & $\begin{array}{l}\text { Ligeiramente } \\
\text { dura }\end{array}$ & Macia & Não plástica \\
\hline 21 & $\begin{array}{l}\text { Bruno muito } \\
\text { claro- } \\
\text { acinzentado }\end{array}$ & $\begin{array}{c}\text { Bruno- } \\
\text { amarelado- } \\
\text { escuro }\end{array}$ & $\begin{array}{l}\text { Areno- } \\
\text { argilosa }\end{array}$ & Laminar & Muito pequena & $\begin{array}{l}\text { Ligeiramente } \\
\text { dura }\end{array}$ & Macia & Não plástica \\
\hline
\end{tabular}


Continuação da tabela 24.

\begin{tabular}{|c|c|c|c|c|c|c|c|c|}
\hline \multirow{2}{*}{$\begin{array}{c}\mathrm{N}^{\circ} \\
\text { amostra }\end{array}$} & \multicolumn{2}{|c|}{ Cor } & \multirow[b]{2}{*}{ Textura } & \multirow[b]{2}{*}{ Estrutura } & \multirow[b]{2}{*}{ Porosidade } & \multicolumn{3}{|c|}{ Consistência } \\
\hline & Seca & Úmida & & & & Seca & Úmida & Molhada \\
\hline 22 & $\begin{array}{c}\text { Amarelo- } \\
\text { avermelhado }\end{array}$ & $\begin{array}{c}\text { Bruno- } \\
\text { amarelado }\end{array}$ & Arenosa & Bloco subangular & Muito pequena & Macia & Macia & Não plástica \\
\hline 23 & Bruno-claro & $\begin{array}{c}\text { Bruno- } \\
\text { amarelado }\end{array}$ & Areno-siltosa & Sem estrutura & Pequena & Macia & Macia & Não plástica \\
\hline 24 & Bruno-claro & $\begin{array}{c}\text { Bruno- } \\
\text { amarelado }\end{array}$ & Areno-siltosa & Sem estrutura & Pequena & Macia & Macia & Não plástica \\
\hline 25 & Bruno-claro & Bruno & Areno-siltosa & Sem estrutura & Pequena & Macia & Macia & Não plástica \\
\hline 26 & $\begin{array}{l}\text { Bruno muito } \\
\text { claro- } \\
\text { acinzentado }\end{array}$ & Bruno & Arenosa & Prismático & Pequena & Solta a Macia & Solta & Não plástica \\
\hline 27 & Amarelo & Bruno & Arenosa & Granular & Muito pequena & Solta & Solta & Não plástica \\
\hline 28 & $\begin{array}{c}\text { Bruno- } \\
\text { avermelhado }\end{array}$ & $\begin{array}{c}\text { Bruno- } \\
\text { avermelhado }\end{array}$ & Arenosa & Sem estrutura & Pequena & Macia & Macia & Não plástica \\
\hline 29 & Bruno-forte & Bruno-forte & Arenosa & Bloco subangular & Pequena & $\begin{array}{c}\text { Macia a } \\
\text { Pouca dura }\end{array}$ & Macia & Não plástica \\
\hline 30 & $\begin{array}{c}\text { Bruno- } \\
\text { avermelhado }\end{array}$ & $\begin{array}{c}\text { Bruno- } \\
\text { avermelhado }\end{array}$ & Arenosa & Sem estrutura & Pequena & Macia & Macia & Não plástica \\
\hline 31 & $\begin{array}{c}\text { Bruno- } \\
\text { amarelado- } \\
\text { claro }\end{array}$ & $\begin{array}{l}\text { Cinzento- } \\
\text { brunado-claro }\end{array}$ & $\begin{array}{l}\text { Areia silto- } \\
\text { argilosa }\end{array}$ & $\begin{array}{c}\text { Bloco subangular de } \\
\text { tamanho variado }\end{array}$ & Pequena & Pouco dura & Plastica & Plastica \\
\hline
\end{tabular}




\section{Continuação da tabela 24.}

\begin{tabular}{|c|c|c|c|c|c|c|c|c|}
\hline \multirow{2}{*}{$\begin{array}{c}\mathrm{N}^{\circ} \\
\text { amostra }\end{array}$} & \multicolumn{2}{|c|}{ Cor } & \multirow[b]{2}{*}{ Textura } & \multirow[b]{2}{*}{ Estrutura } & \multirow[b]{2}{*}{ Porosidade } & \multicolumn{3}{|c|}{ Consistência } \\
\hline & Seca & Úmida & & & & Seca & Úmida & Molhada \\
\hline 32 & $\begin{array}{c}\text { Bruno- } \\
\text { avermelhado- } \\
\text { escuro }\end{array}$ & Bruno & $\begin{array}{c}\text { Areia silto- } \\
\text { argilosa }\end{array}$ & Bloco subangular & Pequena & Plastica & Plastica & Plastica \\
\hline 33 & $\begin{array}{l}\text { Bruno- } \\
\text { avermelhado- } \\
\text { escuro }\end{array}$ & Bruno & $\begin{array}{c}\text { Areia silto- } \\
\text { argilosa }\end{array}$ & Bloco subangular & Pequena & Plastica & Plastica & Plastica \\
\hline 34 & $\begin{array}{l}\text { Bruno- } \\
\text { avermelhado- } \\
\text { escuro }\end{array}$ & Bruno & $\begin{array}{c}\text { Areia silto- } \\
\text { argilosa }\end{array}$ & Bloco subangular & Pequena & Plastica & Plastica & Plastica \\
\hline 35 & $\begin{array}{l}\text { Bruno- } \\
\text { avermelhado- } \\
\text { escuro }\end{array}$ & Bruno & $\begin{array}{c}\text { Areno- } \\
\text { argilosa } \\
\text { c/blocos e } \\
\text { seixos }\end{array}$ & Bloco subangular & Pequena & Macia & Macia & Não plástica \\
\hline
\end{tabular}




\subsubsection{Caracterização geotécnicas dos sedimentos}

A caracterização dos sedimentos foi feita a partir da técnica de pendeiramento, onde as amostras foram coletadas tanto nas margens do Córrego das Cruzes quanto no interior do canal fluvial, em duplicata, conforme os procedimento realizados e citados no tópico 6.9 .

Apesar da avaliação dos materiais geológicos ter sido feita por meio das propriedades físicas e morfológicas dos solos, vistas no tópico 7.1.1, no caso em questão, foi feita pelo método de filtração, onde se obteve os seguintes resultados, conforme expostos na tabela 25 .

Tabela 25 - Teor dos sólidos em suspensão da área de estudo.

\begin{tabular}{|c|c|c|c|}
\hline $\begin{array}{c}\text { No } \\
\text { Amostra }\end{array}$ & $\begin{array}{c}\text { SST } \\
(\mathbf{m g} / \mathbf{l})\end{array}$ & $\begin{array}{c}\text { SSO } \\
(\mathbf{m g} / \mathbf{l})\end{array}$ & $\begin{array}{c}\text { SSI } \\
(\mathbf{m g} / \mathbf{l})\end{array}$ \\
\hline 1 & 0,021 & 0,021 & 0,021 \\
\hline 2 & 1,245 & 1,245 & 1,245 \\
\hline 3 & 1,200 & 0,105 & 1,094 \\
\hline 4 & 1,008 & 0,003 & 1,006 \\
\hline 5 & 1,258 & 0,087 & 1,171 \\
\hline 6 & 1,121 & 0,067 & 1,054 \\
\hline 7 & 0,468 & 0,058 & 0,410 \\
\hline 8 & 0,012 & 0,004 & 0,008 \\
\hline 9 & 0,071 & 0,070 & 0,071 \\
\hline 10 & 0,009 & 0,000 & 0,009 \\
\hline 11 & 0,143 & 0,053 & 0,196 \\
\hline 12 & 4,477 & 0,117 & 4,360 \\
\hline 13 & 0,055 & 0,007 & 0,048 \\
\hline 14 & 0,094 & 0,075 & 0,019 \\
\hline 15 & 0,236 & 0,008 & 0,228 \\
\hline
\end{tabular}

Como se observa na tabela 25, o maior valor observado quanto ao teor de sólidos em suspensão totais (SST) ocorreu apenas na amostra 12 correspondente à região próxima à manilha. 
Este resultado, foi causado provavelmente pelo afunilamento (largura, altura e profundidade do canal), fazendo com que a vazão do canal fluisse em um espaço relativamente pequeno, cerca de uns $1000 \mathrm{~m}$ da desembocadura.

Este resultado vem confirmar a carência de matéria orgânica, o que torna os solos mais pobres e susceptíveis à erosão, no caso dos taludes que existem ao longo da drenagem.

\subsubsection{Avaliação geotécnica da área de estudo}

Com base nos ensaios de infiltração feitos em pontos distintos ao longo da área de estudo, cujos valores encontram-se detalhados no apêncide 4, podemos afirmar que:

Os furos de números 2 a 5 obtiveram os maiores resultados, onde "in-situ", os mesmos foram reiniciados conforme sugere Guerra (2002), por apresentar material geológico de maior permeabilidade, embora o maior número de repetições do ensaio deu-se no furo 6 (3 vezes), seguido do furo 5 (2 vezes).

Ao observar a dinâmica do gado na área de estudo e comparar as informações com base em dados analisados "in situ", constatou-se que quanto mais próximo da área de circulação do gado, menor é a permeabilidade, já que o rebanho circunda, predominantemente, entre próximas à nascente e nos locais com menores declividades, embora quando nestes locais apresentam-se na forma de rampas, mesmo com elevada inclinação, o rebanho pode usar este local no deslocamento do mesmo entre as márgens da drenagem e o canal.

Estes ensaios foram realizados durante a quadra chuvosa, mas com ausência de precipitação pluviométrica durante a realização destes, nas porções próximas à planície de inundação, nas proximidades com o Ribeirão das Cruzes, devido à saturação de água de parte desta localidade, as amostras 1, 2 e 3 apresentarm resultados desfavoforáveis (impermeáveis), como se observa no gráfico 1. 


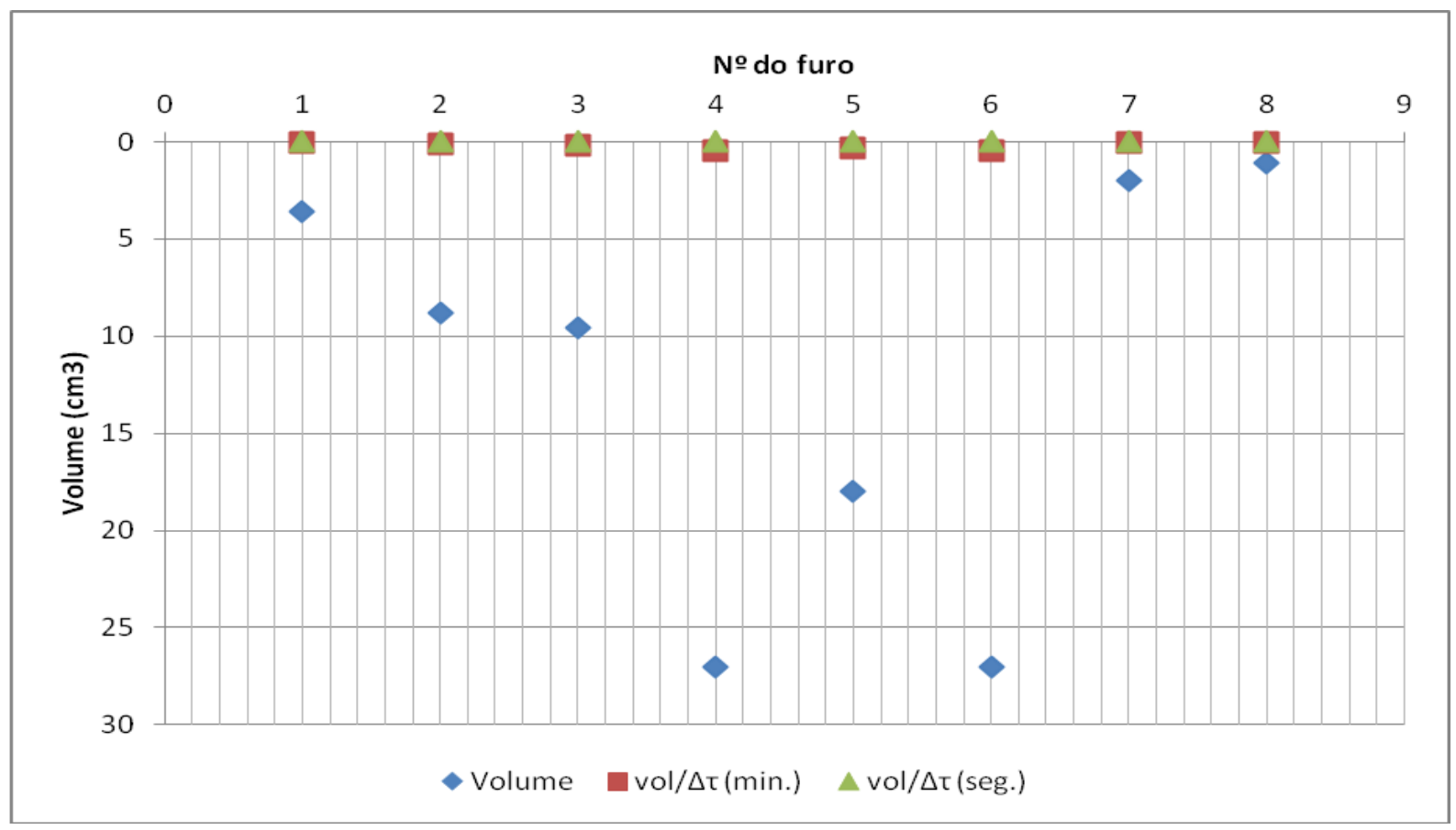

Gráfico 1- Variação do volume de infiltração ao longo da área de estudo.

De modo geral, as maiores permeabilidades foram encontradas no interior do canal, dentro das ilhas arenosas e barras arenosas, ao passo que as menores, nos locais onde o gado pastava (ver figura 31).

A figura 32 (a) mostra a porção do terreno no qual os menores resultados foram levantados, ao passo que na figura 32 (b), foi observado o melhor resultado de permeabilidade, devido ao índice de vazios e baixo nível de saturação.
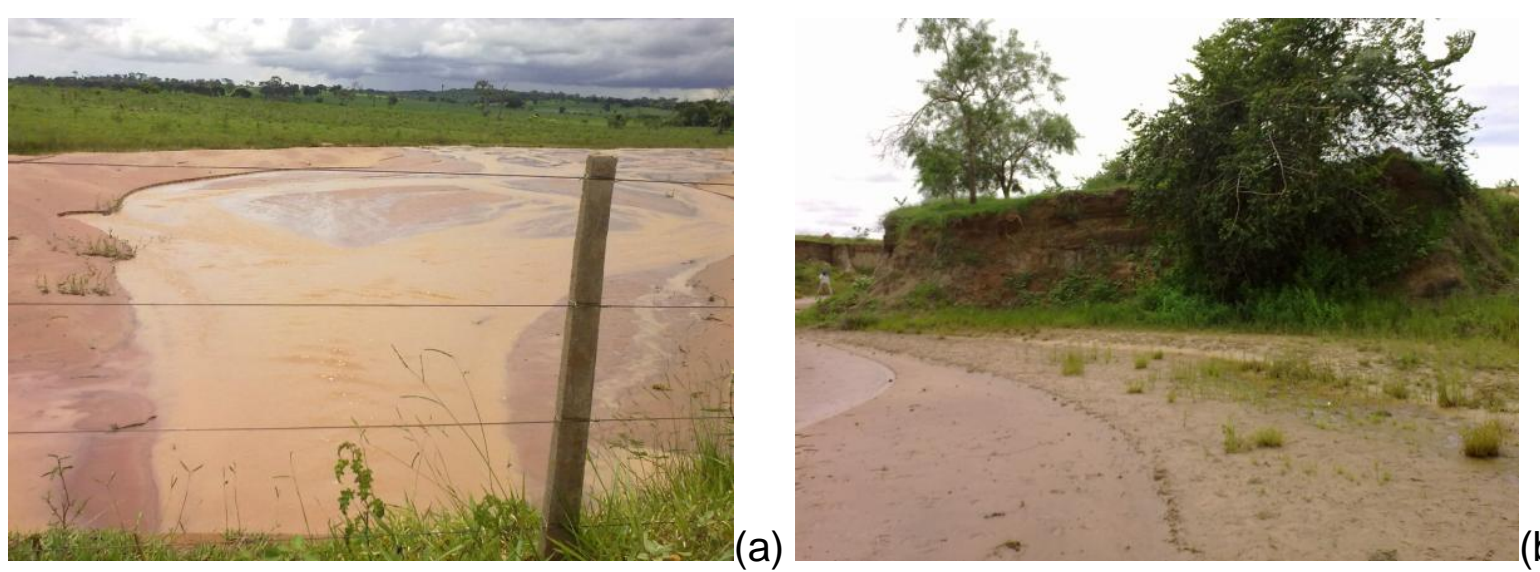

(b)

Figura 32 - Locais utilizados na investigação da permeabilidade do solo (Auto: E. J. Albuquerque Sobrinho).

Com relação à distribuição granulométrica dos "solos" e demais depósitos inconsolidados, percebeu-se que a área de estudo é composta, predominantemente, 
por materiais na fração areia, tendo também a variação do tamanho das partículas em decorrência de sua localização.

Neste caso, quanto mais próximas do local onde aflora uma camada de arenito de cor escura (rico em biotita) de coerência 3, maiores serão os fragmentos, no caso, com seixos e blocos subangulares, devido ao processo de abrasão entre o meio líquido e o fundo rochoso, composto por areia, silte e presença de argila.

Os fragmentos da rocha citada (figura 32-a) são fontes dos materiais de frações maiores ao longo do canal, onde os mesmos são transportados por rolamento; nas porções mais "profundas" do canal e quando nas áreas mais rasas fazem sucos nos sedimentos do leito deixando o rastro deste transporte "toolmark" (figura 33-b).

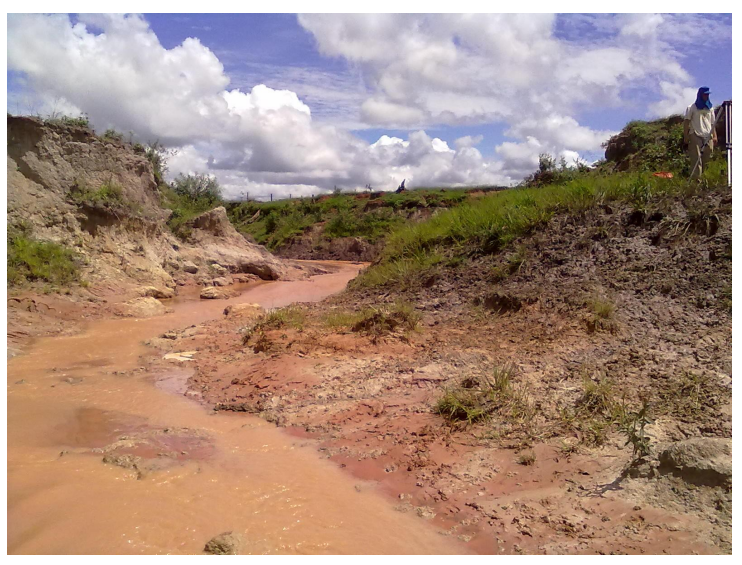

(a)

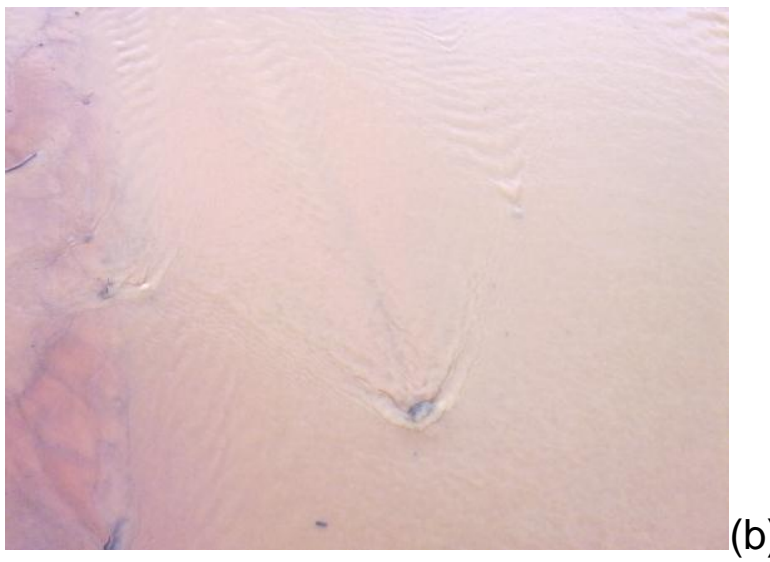

Figura 33 - Afloramento de areníto biotítico (a) e remobilização do fundo e transporte por rolamento do material mais grosseiro (b) (Auto: E. J. Albuquerque Sobrinho). 
Tabela 26 - Distribuição granulométrica dos materiais geológicos da área de estudo.

\begin{tabular}{|c|c|c|c|c|c|c|c|c|c|c|c|c|c|c|c|c|}
\hline \multirow{2}{*}{$\begin{array}{c}\text { № } \\
\text { Amostra }\end{array}$} & \multicolumn{15}{|c|}{ Peneiras } & \multirow{2}{*}{$\begin{array}{c}\Sigma \text { peso } \\
\text { (g) }\end{array}$} \\
\hline & $2 \mu$ & 200 & 100 & 50 & 30 & 16 & 10 & 4 & 1" & $3 / 4$ & $5 / 8$ & $1 / 2$ & $3 / 8$ & $5 / 16$ & $1 / 14$ & \\
\hline 1 & 14,24 & 26,58 & 65,07 & 27,41 & 14,82 & 0,12 & 0,00 & 0,00 & 0,00 & 0,00 & 0,00 & 0,00 & 0,00 & 0,00 & 0,00 & 148,24 \\
\hline 2 & 11,09 & 37,26 & 86,31 & 13,06 & 1,60 & 0,00 & 0,00 & 0,00 & 0,00 & 0,00 & 0,00 & 0,00 & 0,00 & 0,00 & 0,00 & 149,32 \\
\hline 3 & 4,06 & 98,74 & 98,75 & 13,76 & 1,72 & 0,30 & 0,00 & 0,00 & 0,00 & 0,00 & 0,00 & 0,00 & 0,00 & 0,00 & 0,00 & 217,33 \\
\hline 4 & 4,29 & 27,50 & 67,75 & 21,90 & 12,65 & 6,06 & 11,96 & 0,00 & 0,00 & 0,00 & 0,00 & 0,00 & 0,00 & 0,00 & 0,00 & 152,11 \\
\hline 5 & 4,57 & 23,76 & 98,36 & 19,29 & 0,00 & 0,61 & 0,16 & 0,00 & 0,00 & 0,00 & 0,00 & 0,00 & 0,00 & 0,00 & 0,00 & 146,75 \\
\hline 6 & 17,71 & 33,00 & 74,22 & 20,84 & 2,63 & 0,52 & 0,07 & 0,00 & 0,00 & 0,00 & 0,00 & 0,00 & 0,00 & 0,00 & 0,00 & 148,99 \\
\hline 7 & 21,10 & 33,10 & 58,18 & 21,15 & 8,48 & 5,92 & 0,12 & 0,00 & 0,00 & 0,00 & 0,00 & 0,00 & 0,00 & 0,00 & 0,00 & 148,05 \\
\hline 8 & 4,31 & 18,31 & 96,98 & 27,74 & 5,56 & 0,43 & 0,47 & 0,00 & 0,00 & 0,00 & 0,00 & 0,00 & 0,00 & 0,00 & 0,00 & 153,80 \\
\hline 9 & 3,67 & 20,58 & 99,49 & 24,90 & 0,62 & 0,13 & 0,00 & 0,00 & 0,00 & 0,00 & 0,00 & 0,00 & 0,00 & 0,00 & 0,00 & 149,39 \\
\hline 10 & 18,78 & 40,12 & 79,03 & 8,74 & 1,24 & 0,47 & 0,00 & 0,00 & 0,00 & 0,00 & 0,00 & 0,00 & 0,00 & 0,00 & 0,00 & 148,38 \\
\hline 11 & 23,27 & 47,38 & 65,86 & 10,53 & 1,78 & 0,19 & 0,10 & 0,00 & 0,00 & 0,00 & 0,00 & 0,00 & 0,00 & 0,00 & 0,00 & 149,11 \\
\hline 12 & 18,05 & 47,72 & 69,21 & 11,85 & 1,70 & 0,49 & 0,04 & 0,00 & 0,00 & 0,00 & 0,00 & 0,00 & 0,00 & 0,00 & 0,00 & 149,06 \\
\hline 13 & 6,22 & 24,29 & 80,95 & 21,12 & 8,66 & 3,48 & 9,29 & 0,00 & 0,00 & 0,00 & 0,00 & 0,00 & 0,00 & 0,00 & 0,00 & 154,01 \\
\hline 14 & 24,70 & 39,00 & 55,36 & 17,33 & 7,85 & 4,34 & 0,03 & 0,00 & 0,00 & 0,00 & 0,00 & 0,00 & 0,00 & 0,00 & 0,00 & 148,61 \\
\hline 15 & 20,90 & 41,50 & 50,78 & 14,15 & 11,93 & 9,73 & 0,21 & 0,00 & 0,00 & 0,00 & 0,00 & 0,00 & 0,00 & 0,00 & 0,00 & 149,20 \\
\hline 16 & 1,06 & 11,84 & 119,61 & 17,45 & 0,25 & 0,02 & 0,00 & 0,00 & 0,00 & 0,00 & 0,00 & 0,00 & 0,00 & 0,00 & 0,00 & 150,23 \\
\hline 17 & 12,46 & 34,78 & 217,31 & 47,20 & 10,00 & 15,50 & 49,95 & 13,78 & 0,00 & 0,02 & 0,03 & 0,03 & 0,03 & 22,57 & 21,59 & 445,25 \\
\hline 18 & 47,06 & 66,41 & 22,78 & 7,27 & 5,10 & 0,10 & 0,25 & 0,00 & 0,00 & 0,00 & 0,00 & 0,00 & 0,00 & 0,00 & 0,00 & 148,97 \\
\hline 19 & 9,00 & 51,37 & 85,75 & 2,44 & 0,30 & 0,06 & 0,00 & 0,00 & 0,00 & 0,00 & 0,00 & 0,00 & 0,00 & 0,00 & 0,00 & 148,92 \\
\hline 20 & 6,67 & 34,60 & 103,24 & 5,25 & 0,07 & 0,01 & 0,00 & 0,00 & 0,00 & 0,00 & 0,00 & 0,00 & 0,00 & 0,00 & 0,00 & 149,84 \\
\hline 21 & 50,78 & 77,95 & 6,80 & 4,41 & 7,70 & 1,27 & 0,00 & 0,00 & 0,00 & 0,00 & 0,00 & 0,00 & 0,00 & 0,00 & 0,00 & 148,91 \\
\hline 22 & 11,02 & 36,93 & 84,67 & 12,41 & 2,56 & 1,38 & 0,26 & 0,00 & 0,00 & 0,00 & 0,00 & 0,00 & 0,00 & 0,00 & 0,00 & 149,23 \\
\hline 23 & 3,65 & 30,86 & 101,28 & 13,17 & 0,37 & 0,17 & 0,32 & 0,00 & 0,00 & 0,00 & 0,00 & 0,00 & 0,00 & 0,00 & 0,00 & 149,82 \\
\hline 24 & 3,56 & 38,15 & 94,66 & 12,67 & 0,30 & 0,06 & 0,00 & 0,00 & 0,00 & 0,00 & 0,00 & 0,00 & 0,00 & 0,00 & 0,00 & 149,40 \\
\hline
\end{tabular}


Continuação da tabela 25.

\begin{tabular}{|c|c|c|c|c|c|c|c|c|c|c|c|c|c|c|c|c|}
\hline \multirow{2}{*}{$\begin{array}{c}\text { № } \\
\text { Amostr } \\
\text { a }\end{array}$} & \multicolumn{15}{|c|}{ Peneiras } & \multirow{2}{*}{$\begin{array}{c}\Sigma \text { peso } \\
\text { (g) }\end{array}$} \\
\hline & $2 \mu$ & 200 & 100 & 50 & 30 & 16 & 10 & 4 & 1" & $3 / 4$ & $5 / 8$ & $1 / 2$ & $3 / 8$ & $5 / 16$ & $1 / 14$ & \\
\hline 25 & 28,94 & 51,89 & 57,26 & 9,35 & 4,48 & 0,83 & 0,93 & 0,00 & 0,00 & 0,00 & 0,00 & 0,00 & 0,00 & 0,00 & 0,00 & 153,68 \\
\hline 26 & 7,27 & 38,27 & 97,83 & 9,56 & 1,27 & 0,04 & 0,00 & 0,00 & 0,00 & 0,00 & 0,00 & 0,00 & 0,00 & 0,00 & 0,00 & 154,24 \\
\hline 27 & 5,41 & 28,87 & 97,38 & 19,98 & 2,58 & 0,06 & 0,04 & 0,00 & 0,00 & 0,00 & 0,00 & 0,00 & 0,00 & 0,00 & 0,00 & 154,32 \\
\hline 28 & 23,09 & 30,82 & 32,11 & 7,34 & 14,96 & 7,95 & 7,42 & 0,00 & 0,00 & 0,00 & 0,00 & 0,00 & 0,00 & 0,00 & 0,00 & 123,69 \\
\hline 29 & 27,53 & 37,45 & 47,82 & 9,22 & 13,61 & 8,52 & 9,02 & 0,00 & 0,00 & 0,00 & 0,00 & 0,00 & 0,00 & 0,00 & 0,00 & 153,17 \\
\hline 30 & 19,04 & 58,28 & 57,57 & 7,94 & 5,42 & 0,79 & 0,03 & 0,00 & 0,00 & 0,00 & 0,00 & 0,00 & 0,00 & 0,00 & 0,00 & 149,07 \\
\hline 31 & 17,88 & 40,89 & 71,76 & 15,33 & 2,67 & 0,20 & 0,06 & 0,00 & 0,00 & 0,00 & 0,00 & 0,00 & 0,00 & 0,00 & 0,00 & 148,79 \\
\hline 32 & 5,39 & 22,85 & 61,73 & 21,84 & 15,97 & 5,60 & 7,43 & 0,00 & 0,00 & 0,00 & 0,00 & 0,00 & 0,00 & 0,00 & 0,00 & 140,81 \\
\hline 33 & 6,13 & 21,09 & 54,73 & 21,84 & 13,92 & 7,14 & 7,65 & 0,00 & 0,00 & 0,00 & 0,00 & 0,00 & 0,00 & 0,00 & 0,00 & 164,58 \\
\hline 34 & 9,00 & 26,03 & 61,73 & 11,62 & 21,11 & 5,16 & 7,39 & 0,00 & 0,00 & 0,00 & 0,00 & 0,00 & 0,00 & 0,00 & 0,00 & 176,45 \\
\hline 35 & 5,39 & 22,85 & 57,14 & 21,87 & 20,06 & 6,09 & 3,43 & 0,00 & 0,00 & 0,00 & 0,00 & 0,00 & 0,00 & 0,00 & 0,00 & 171,83 \\
\hline
\end{tabular}




\subsection{Protocolo de Avaliação de Rápidos (EPA, 1981; adaptado de CALLIXTO et al., 2002; XAVIER \& TEIXEIRA, 2007)}

Apesar de outros estudos de casos relacionados ao emprego do Protocolo de Avaliação de Rápidos (EPA, 1981) tenha apresentado resultados favoráveis por outros autores, no presente estudoisso não ocorreu, já que as variáveis contidas nesta técnica é limitada por uma combinação de cenários avaliativos, talvez por causa do foco investigativo (ecológico).

A partir da aplicação de 24 formulários desta ferramenta de avaliação qualitativa dos ambientes fluviais, ao longo de segmentos da drenagem em questão, foram obtidos os seguintes resultados, como pode ser observado no gráfico 1:

A partir da observação do gráfico 1 , percebe-se que a menor pontuação (28 pontos) ocorreu no protocolo de $n^{\circ} 7$, ao passo que o maior valor foi observado no protocolo de $n^{\circ} 15$ (impactados), cujo valor total foi de 64 pontos (naturais), e a média oriunda da pontuação de todos os locais amostrados foi de 42,46 pontos (muito alterados).

Embora a desembocadura contenha duas bocas, os valores observados são levemente distintos um do outro, onde o canal direito obteve o valor total de 39 pontos e o da esquerda 33, caracterizando-nas como sendo impactados, como se observa na figura 34 .

Tanto a tabela 27, quanto o gráfico 2 contêm todos os dados copilados a partir da aplicação do comentado protocolo, cujo somatório variou entre os pontos, sendo que o menor valor observado ocorreu no ponto no ponto 8 (28 pontos) e máximo nos pontos 15 (64 pontos) e 22 (63 pontos).

Como percebe-se, a distribuição dos valores por protocolo não é homogênea, embora as variáveis propostas pelo protocolo aqui testado, não seja a melhor opção para avaliar o papel das questões ambientais na qualidade física dos rios, conforme visto, anteriormente, nas tabelas 19 a 22. 


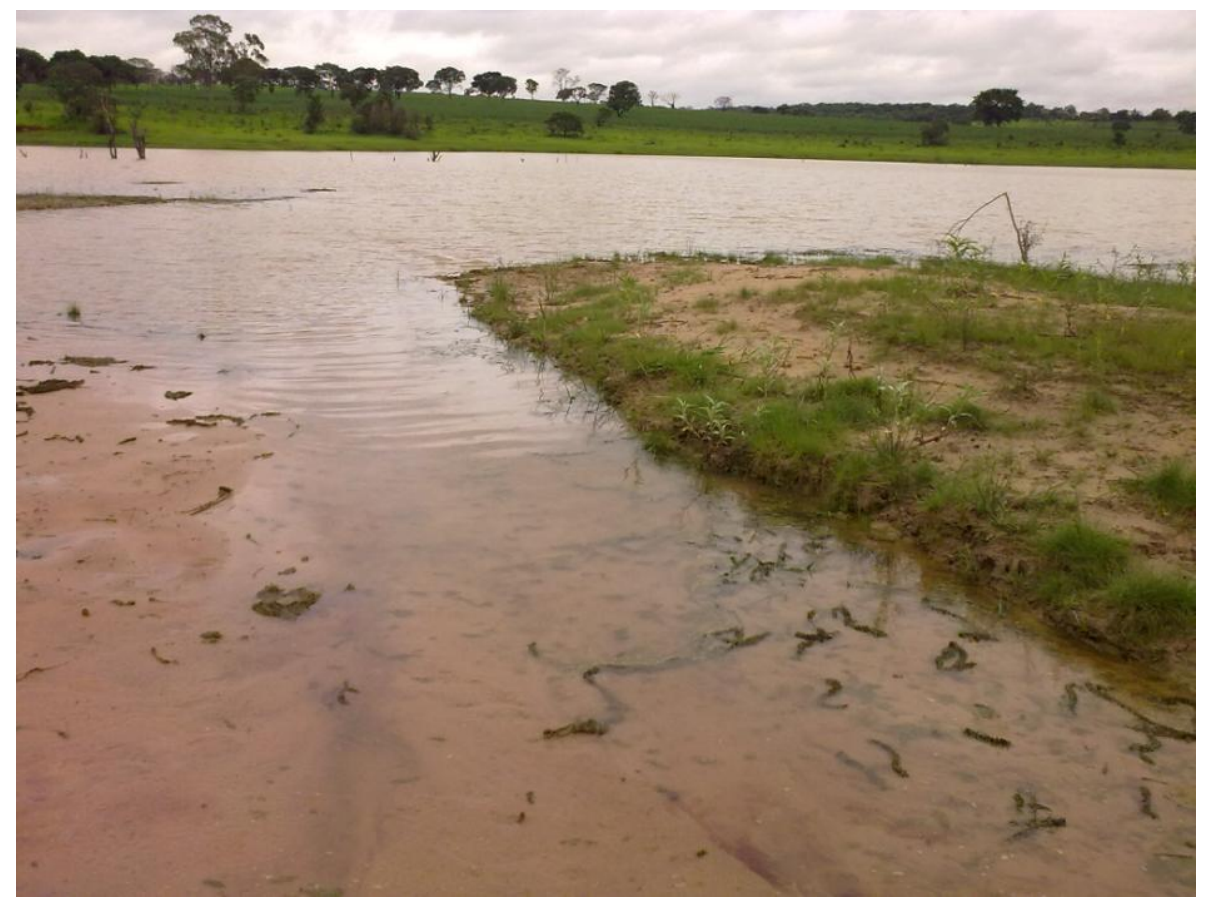

Figura 34 - Vista da desembocadura direita (Autor: E. J. Albuquerque Sobrinho).

Com relação à bifurcação que ocorre entre ambas as drenagens destinadas ao Ribeirão das Cruzes, tal porção do canal está sujeita à estiagem, onde a circulação hídrica nesta porção é interrompida pelo decréscimo na lâmina d'água não ser possível transpassar os depósitos sedimentares existente no interior da drenagem, na forma de "microtidals", depósitos estratificados plano-paralelos, estratificação cruzadas da baixo ângulo, "ripple currents" e marcas de objetos, como se observa na figura 35.

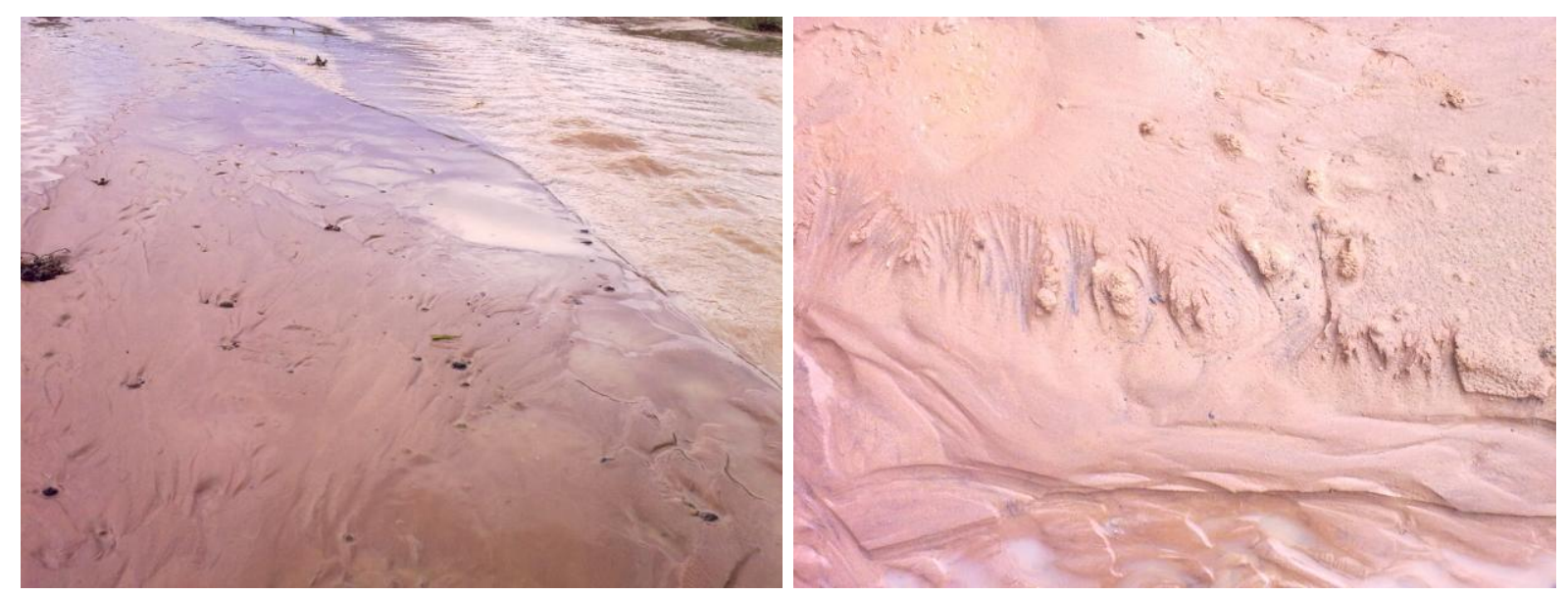

Figura 35 - Estratificações formadas pela interação hidrodinâmicas nas proximidades da desembocadura do Córrego das Cruzes com o ribeirão de mesmo nome (Autor: E. J. Albuquerque Sobrinho). 
Ao comparar todos os valores obtidos na área de estudo com os estabelecidos pelo Protocolo de Avaliação de Rápidos (EPA, 1981), a média geral classificaria o corpo hídrico como sendo impactado, embora a distribuição por pontos de amostragem tenha apresentando valores discrepantes entre si, não condizentes com a realidade local, que à vezes segmentos são classificados como sendo naturais (pontos 16 e 23); porém, estando esses bem distantes do "natural", posto que a área sofre com o uso abusivo de suas margens, que se reflete na dinâmica ambiental. Ocorrendo a modificação de uso, não amortece os impactos gerados e ampliados ao longo do tempo.

O protocolo aqui discutido classifica como sendo natural estes aspectos: quando se apresenta, pelo menos $50 \mathrm{~m}$ de vegetação natural ao redor do olho d'água das nascentes pontuais ou a partir do olho d'água principal em nascentes difusas; contendo vegetação ripária natural no trecho de $300 \mathrm{~m}$ a partir do olho d'água em ambas as margens; influência antrópica mínima ou ausente (EPA, 1981; adaptado de CALLIXTO et al., 2002; XAVIER \& TEIXEIRA, 2007).

A partir da aplicação do protocolo, chegou-se aos valores correspondentes à pontuação total, pontuação média por questionário e desvio padrão, como se observa no gráfico 2 .

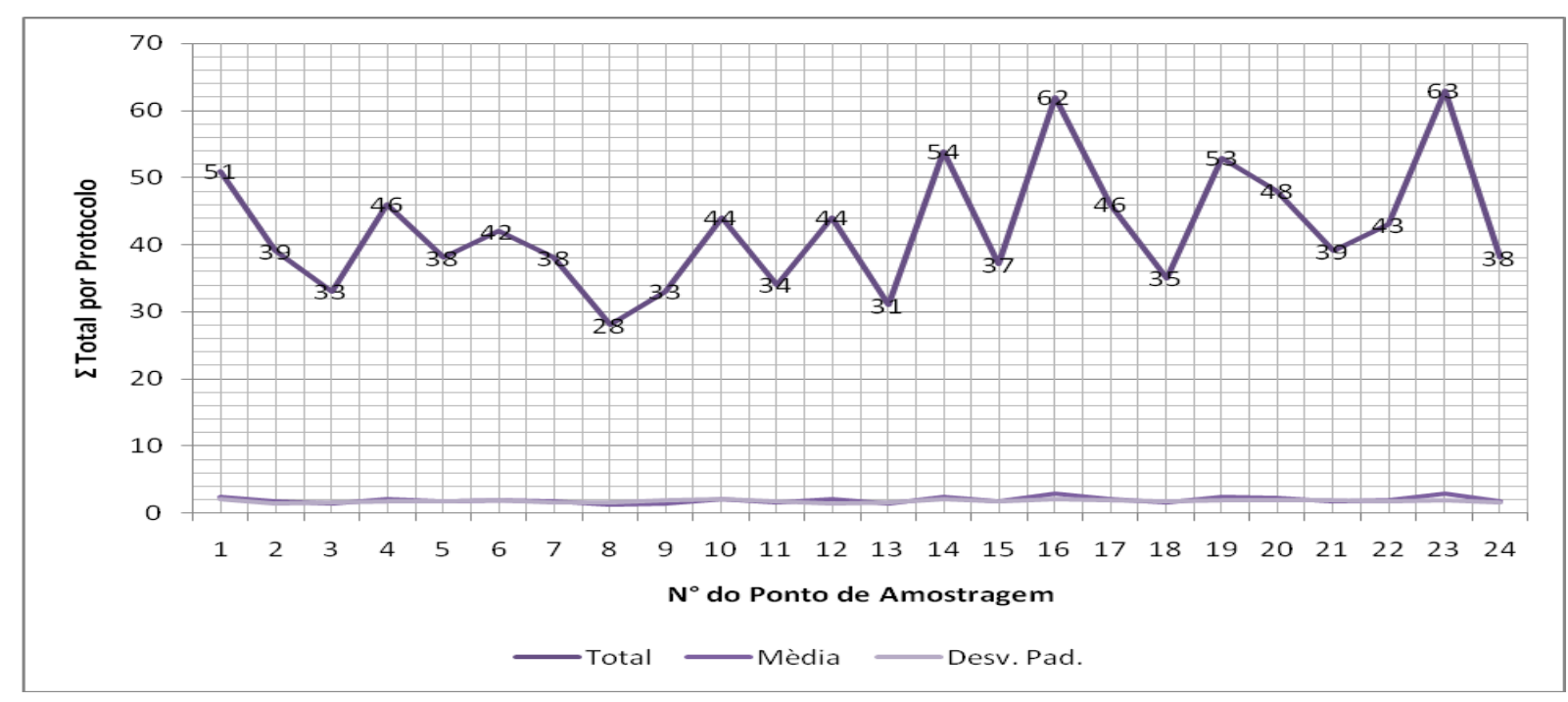

Gráfico 2 - Valores referentes à média e desvio padrão dos Protocolo de Avaliação de Rápidos). 
O estudo preliminar feito por Albuquerque Sobrinho et al. (2010) no Córrego das Cruzes, Lócus do objeto de estudo da presente tese, foi classificado como sendo impactado.

Os valores apresentados no gráfico 2 podem ser observados, detalhadamente, na tabela 27 , incluindo a média e desvio padrão dos mesmos.

Tabela 27 - Distribuição geral da pontuação do Protocolo de Avaliação de Rápidos (EPA, 1981).

\begin{tabular}{|c|c|c|c|c|c|c|c|c|}
\hline \multirow{3}{*}{$\begin{array}{c}\mathbf{N}^{\circ} \\
\text { Protocolo }\end{array}$} & \multicolumn{5}{|c|}{ Pontuação aplicada } & \multirow[t]{3}{*}{ Etotal } & \multirow[t]{3}{*}{ Média } & \multirow[t]{3}{*}{$\begin{array}{l}\text { Desvio } \\
\text { Padrão }\end{array}$} \\
\hline & 0 & 2 & 3 & 4 & 5 & & & \\
\hline & \multicolumn{5}{|c|}{ Frequência de Pontuação } & & & \\
\hline 1 & 7 & 9 & 3 & 3 & 0 & 39 & 1,77 & 1,41 \\
\hline 2 & 9 & 10 & 0 & 2 & 1 & 33 & 1,50 & 1,50 \\
\hline 3 & 7 & 8 & 1 & 3 & 3 & 46 & 2,09 & 1,80 \\
\hline 4 & 9 & 7 & 1 & 4 & 1 & 38 & 1,73 & 1,70 \\
\hline 5 & 9 & 5 & 1 & 6 & 1 & 42 & 1,91 & 1,82 \\
\hline 6 & 8 & 8 & 2 & 4 & 0 & 38 & 1,73 & 1,52 \\
\hline 7 & 11 & 9 & 0 & 0 & 2 & 28 & 1,27 & 1,55 \\
\hline 8 & 12 & 4 & 1 & 3 & 2 & 33 & 1,50 & 1,87 \\
\hline 9 & 10 & 3 & 1 & 5 & 3 & 44 & 2,00 & 2,05 \\
\hline 10 & 11 & 6 & 0 & 3 & 2 & 34 & 1,55 & 1,82 \\
\hline 11 & 6 & 8 & 4 & 4 & 0 & 44 & 2,00 & 1,45 \\
\hline 12 & 10 & 9 & 1 & 0 & 5 & 31 & 1,41 & 1,56 \\
\hline 13 & 8 & 2 & 2 & 6 & 5 & 54 & 2,45 & 2,06 \\
\hline 14 & 9 & 8 & 1 & 2 & 2 & 37 & 1,68 & 1,70 \\
\hline 15 & 6 & 3 & 0 & 7 & 6 & 64 & 2,91 & 2,04 \\
\hline 16 & 10 & 4 & 0 & 6 & 2 & 42 & 1,91 & 1,97 \\
\hline 17 & 10 & 4 & 2 & 5 & 1 & 39 & 1,77 & 1,82 \\
\hline 18 & 7 & 5 & 0 & 7 & 3 & 53 & 2,41 & 1,94 \\
\hline 19 & 8 & 3 & 3 & 7 & 1 & 48 & 2,18 & 1,84 \\
\hline 20 & 10 & 4 & 1 & 5 & 2 & 41 & 1,86 & 1,93 \\
\hline 21 & 9 & 6 & 0 & 5 & 2 & 42 & 1,91 & 1,87 \\
\hline 22 & 5 & 3 & 3 & 7 & 4 & 63 & 2,86 & 1,83 \\
\hline 23 & 9 & 5 & 4 & 4 & 0 & 38 & 1,72 & 1,61 \\
\hline 24 & 8 & 5 & 3 & 5 & 1 & 44 & 2,00 & 1,75 \\
\hline
\end{tabular}

Legenda: $\Sigma$ total $=$ somatório total da pontuação por protocolo. 


\subsection{Análise morfométrica da área de estudo}

À partir dos dados coletados por meio da topografia, bem como, no registro cartográfico do terreno, foram obtidos os seguintes resultados (tabela 28):

Tabela 28 - Descrição dos parâmetros morfométricos da área de estudo.

\begin{tabular}{|c|c|}
\hline Parâmetros morfométricos & Valor observado \\
\hline № de ordem total $\left(\Sigma^{\mathrm{Nu}}\right)$ & $2^{\mathrm{a}}$ ordem \\
\hline Comprimento total $\left(\Sigma^{\mathrm{L}}\right)$ & $3.743,00 \mathrm{~m}$ \\
\hline Taxa de bifurcação $(\mathrm{Rb})$ & 0,33 \\
\hline Área $\left(\mathrm{km}^{2}\right)$ & 7,81 \\
\hline Frequencia de drenagem (Fs) & 0,26 \\
\hline Razão textural (T) & 0,0013 \\
\hline Relevo da bacia (Bh) & $22,11 \mathrm{~m}$ \\
\hline Número robustez (Rn) & 21,63 \\
\hline Relação de Relevo (Rr) & 0,006 \\
\hline Densidade hidrográfica (Dh) & $0,38 \mathrm{~km}^{2}$ \\
\hline Densidade de drenagem (Dd) & 0,48 \\
\hline Densidade de rios (Dr) & 0,26 \\
\hline Gradiente de canais (Gc) & 5,91 \\
\hline Coeficiente de manutenção $(\mathrm{Cm})$ & 2083,33 \\
\hline Índice de rugosidade (Ir) & 10.61 \\
\hline Índice de circularidade (Ic) & 0,17 \\
\hline Fator de Forma (Kf) & 2,09 \\
\hline
\end{tabular}

A relação de bifurcação da drenagem em questão, apresentou-se inferior ao limite favorável ( 3 e 5), cujo valor foi de 0,33 , classificando-o como desfavorável (STRAHLER, 1964 apud AGUIAR, 2009).

Estes dados sugerem que o corpo d'água em questão não é bem desenvolvido, posto que o mesmo se apresenta com hierarquia máxima de segunda ordem, em ambas as nascentes (primeira ordem) cujo comprimento máximo destas, são inferiores a $300 \mathrm{~m}$, predominando o canal principal, que se formou a partir da junção dos canais comentados, prolongando-se em direção ao Ribeirão de mesmo nome, intercalados entre seções retilíneas e meandrantes. 


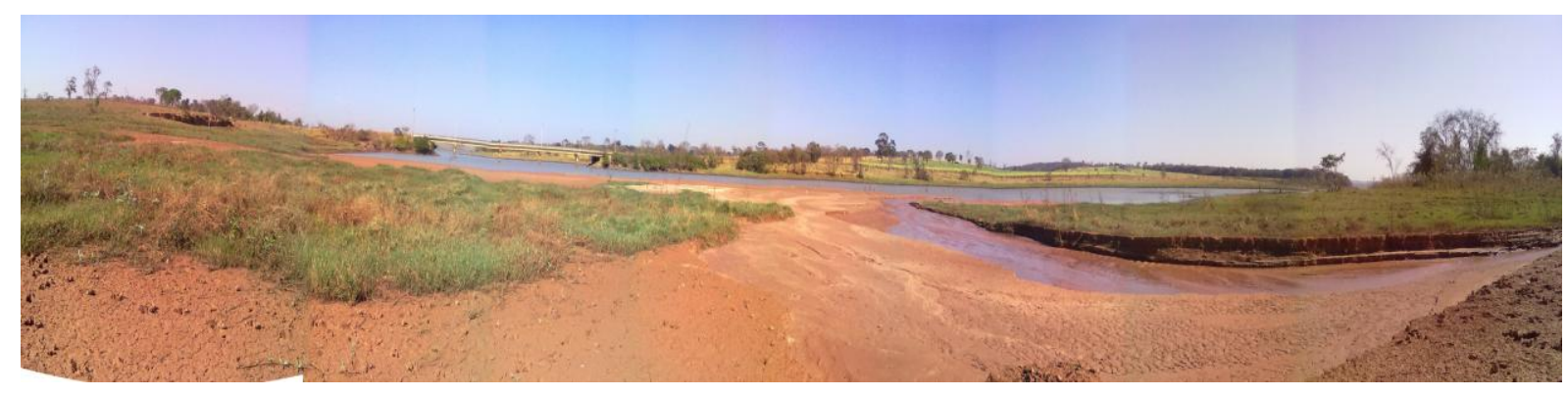

Figura 36 - Vista da desembocadura direita (perene) ao fundo o Ribeirão das Cruzes (Autor: E. J. Albuquerque Sobrinho).

A figura 36 mostra a desembocadura da drenagem em questão com o córrego homônimo, cujo o segmento à esquerda, é intermitente, conforme registro fotográfico feito no período de estiagem, que corresponde aos meses de inverno do hemisfério sul.

Devido à composição geológica e geomorfológica local, este córrego apresenta uma variação de altura de $22 \mathrm{~m}$, entre a porção mais elevada e a mais baixa do terreno desta micro-bacia (ao se considerar todo o canal como sendo uma microbacia).

Embora estes parâmetros sejam usados na caracterização geomorfológica, sob o ponto de vista qualitativo, os mesmos não exprimem bem a relação entre estes dados e o estado atual de conservação, tornando esta ferramenta um tanto inadequada para a tarefa que esta tese se propõe.

O valor observado da frequência de drenagem ou densidade de segmentos da área de estudo foi de 0,26.

O fator de forma da bacia apresentou-se elevado $(2,09)$, indicando uma tendência a diminuição de enchentes em seu interior, embora eventos extremos desta natureza tenham ocorridos no interior da drenagem, promovendo a ruptura de dois pequenos reservatórios existentes anteriormente na área de estudo.

O regime climático da região apresenta duas estações bem distintas, repercurtindo na dinâmica hidrossedimentológica, em conjunto com o uso e ocupação local.

Contudo, os dados morfométricos não expressam tal questão, requerendo assim, uma complementação da geoinformação, com dados oriundo de fontes distintas. 
Embora a densidade de drenagem da área de estudo apresentou o valor de 0,48 (Dd), indicando como sendo um local que apresenta uma permeabilidade elevada no local, tal fato não foi observado no presente momento, com excessão dos bancos de areia e encontram-se com maior frequencia, desde a desembocadura até a distância de aproximadamente $2000 \mathrm{~m}$ rio a dentro.

Talvez isto se deva ao uso que se fez (faz) da terra, pois até o início de 2011, o uso era voltado para pecuária de corte, cujo número de animais bovinos era de 20.000 unidades, a circulação dos mesmos pode ter alterado a permeabilidade do solo, embora o presente estudo não obteve dados anteriores ao uso do solo comentado.

Com relação à densidade de rios (Dr), o valor observado foi de 0,48 , baseado na relação entre o número de segmentos da drenagem (2 segmentos) pela área, cujos dados implicam na capacidade que um determinado rio tem em gerar novos cursos d'água.

A relação entre o comprimento da bacia, no caso da drenagem em questão, com sua área $\left(\mathrm{I}_{\mathrm{c}}\right)$, foi considerado como sendo de forma alargada, embora a porção mais larga encontra-se nas proximidades da desembocadura como o ribeirão homônimo, ao contrário do que comenta Christofoletti (1980), para valores inferiores a 1,00 e classificado como baixo, segundo os limites apresentados por Collares (2000). 


\section{PROPOSTA DE SISTEMA DE AVALIAÇÃO DE EROSÃO FLUVIAL}

Com base no levantamento preliminar feito sobre o tema degradação ambiental em cursos d'água e nas variáveis que influenciam no estado de degradação/conservação ambiental destes, percebeu-se o quanto é subjetivo o tema em questão.

Tal fato está associado a ausência de padronização das variáveis ligadas a esta questão, por se tratarem de estudos particulares, dificultando a comparação entre diferentes drenagem, pois dependendo do referencial teórico-metodológico adotado, resultados conflitantes podem ocorrer, o que se justifica para a proposição do tema da tese em questão, já que a degradação pode ser materializada na forma, por exemplo, de erosão das margens dos canais e assoreamento do canal.

Como as variáveis que regem à dinâmica ambiental são amplas, bem como, a percepção sobre seu estado de conservação, além das técnicas usadas nestas investigações, que variam entre sí, onde as principais linhas de investigação podem ser ecológica, geomorfológica, geológico-geotécnica, ecotoxicológica, dentre outros.

Entretanto dependendo da localização espacial de uma determinada drenagem, os processos distintos vão atuar com maior ou menor energia, embora eventos catastróficos em escala local e regional (tsuname, terremotos, furacões, etc.) possam alterar a dinâmica fluvial (erosão e/ou assoreamento) e degradar ambientes tidos como naturais.

Estes eventos em áreas urbanizadas causam danos ainda maiores, por envolverem o maior número possível de pessoas, ceifando suas vidas e causando problemas sócio-econômicos e ambientais.

Pensando nestas considerações, decidiu-se elaborar um sistema que ajudasse a avaliar, de forma mais apropriada quanto possível, os problemas que assolam os rios, de modo a permitir uma análise relativamente detalhada, cujos dados pudessem ser usados no planejamento do uso do solo (planície fluvial) mais adequado a realidade local, como também, permitisem a comparação de segmentos dentro da área do próprio rio, embora não seja o objetivo desta tese. 
Indiretamente, esta técnica poderia ser usada como ferramenta de cunho didático (educação ambiental) voltado à análise ambiental, tanto na escala de bacia quanto de drenagem, de disciplinas destinadas à educação ambiental, planejamento ambiental, geologia geral, geomorfologia fluvial, ciências do ambiente e em recursos hídricos.

Estas informações, após levantadas (campo, laboratório e gabinete) ajudariam em uma melhor utilização das drenagens, já que suas vulnerabilidades seriam expostas, contribuindo ainda no planejamento ambiental, observando as limitações físicas do espaço "natural" e construido.

Apesar desta ferramenta ter sido testada em um setor agrário do município de Santo Antônio do Aracanguá/SP, a mesma foi pensada para ser empregada sob diferentes tipos de uso e ocupação, como em áreas urbana e industriais.

Inicialmente, pensou-se em utilizar 74 parâmetros, mas a complexidade envolvida era tanta que dificultaria sua aplicação por outras pessoas.

Sendo assim, decidiu-se em reduzir o número de variáveis, para as que ocorrem com maior frequência na degradação dos rios.

Quanto ao público alvo desta ferramenta, a mesma foi pensado para ser utilizada para os profissionais de geociências, como geógrafos, geólogos, ecologistas, engenheiros ambientais e engenheiros de agrimensura, embora seja possível a aplicação por meio de equipe multi-disciplinar.

Este sistema foi compartimentado em grupos de parâmetros distintos: climático; geológico (solos e rochas); geomorfológico; hidráulico; pedológicos; ecológicos; uso e ocupação, totalizando 33 variáveis, cuja abordagem é multicritério.

Embora tenha-se feito uma significativa redução no número de variáveis, esta ferramenta de cunho investigativo, é predominantemente qualitativa, embora parte das informações a serem preenchidas deve ser analisadas em laboratório, como no caso da granulometria, ou mesmo em campo (por exemplo, medição de vazão).

É sugerido um registro cartográficos dos dados analisados, de modo a entender a distribuição espacial quali-quantitativa dos geodados e um tratamento estatístico básico destas informações, onde o número de formulários preenchidos tem que ser representativo às condições de uma determinada área de estudo. 
Com relação a pontuação, inicialmente pensou-se em adotar o método Delphi, com base na consulta aos especialistas relacionados e correlacionados com o tema em proposição, por se tratar de um poderoso instrumento de pesquisa (KAYO \& SECURATO, 1997).

Apesar do aval positivo de participação de especialistas convidados, a fim de definirem as variáveis e seus respectivos pesos, nenhum deles enviou informações quanto a tais questões, onde devido ao tempo para testagem da ferramenta, bem como, tempo para desenvolvimento da tese, foi requerido adotar os pesos e variáveis.

Para isto, adotou-se uma escala inversa, onde quanto mais próximo de 1 , mais próximo do estado de conservação denominado como natural (ausente de problemas causados pelo uso e ocupação, embora sob condições ambientais distintas, tais locais possam ser alterados, como por exemplo, eventos tempestuosos, em local com condições proprícias à erosão, por exemplo), ao passo que, quanto mais próximo de 9 , mais degradado é o local, como por exemplo, em áreas de uso misto (urbano/rural), com presença de infra-estruturas mal planejadas, sem conservação, ausente de práticas conservacionistas, cujas condições geoambientais sejam susceptíveis a erosão e aos demais problemas de natureza geotécnicas.

Para facilitar na compreensão da pontuação e seus respectivos limites, em cada grupo de parâmetros foi incluído uma tabela com limites de cada grupo, de modo a se definir quais grupos de variáveis tiveram maior participação no estado de conservação de um determinado corpo aquoso.

Com base nas variáveis que estão intimamente relacionadas e correlacionadas ao problema de degradação dos corpos fluviais, segue abaixo os parâmetros a serem aplicados na avaliação destes ambientes (A distribuição dos locais de investigação pode ser vista na figura 37). 


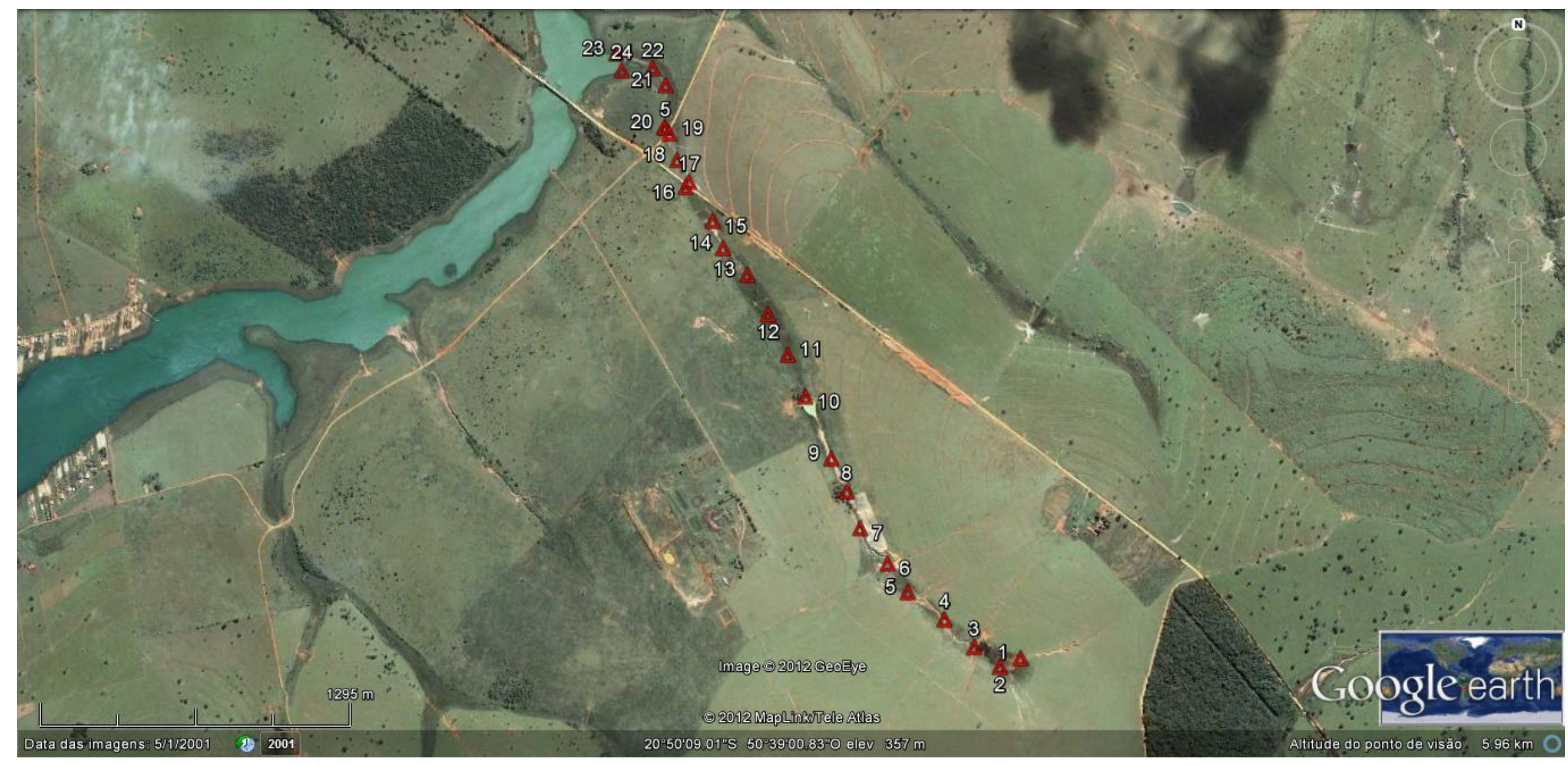

Figura 37 - Distribuição espacial dos pontos investigados pelo Sistema de Avaliação Geoambiental em proposição (Fonte: Google Earth, 2012). 


\subsection{Parâmetros Climáticos}

Com base nas observações feitas quanto ao papel do clima, que se encontra no tópico 4.2.1, definiu-se os pesos deste parâmetro, com base na classificação de Köppen \& Geiger (1928) apud Peel; Finlayson; McMahon (2007), como se observa na tabela 29.

De acordo com a tabela 29, os valores de maior pesos foram atribuídos aos climas Árido (B) e Glacial (E) devido aos eventos tempestuosos que ocorrerm na regiões de clima árido, cujo volume d'água é elevado e de curta duração, gerando diversos problemas, incluindo a degradação ambiental. No caso do clima Glacial (E) seu peso elevado foi atribuído ao papel que o gelo exerce na transformação do relevo, na forma de depósitos glaciares.

Tabela 29 - Tipo climático local (KÖPPEN \& GEIGER, 1928 apud PEEL; FINLAYSON; MCMAHON, 2007).

\begin{tabular}{|c|c|c|}
\hline Tipologia & Volume (mm/ano) & Peso \\
\hline Tropical (A) & $>1.500$ & 1 \\
\hline Árido (B) & $\begin{array}{l}\text { Climas secos e precipitação } \\
\text { anual inferior a } 500 \mathrm{~mm}\end{array}$ & 9 \\
\hline Temperado (C) & $\begin{array}{c}1.100-2.000 \\
\text { Estações de Verão e Inverno } \\
\text { bem definidas }\end{array}$ & 6 \\
\hline Continental (D) & $\begin{array}{c}\text { Estações de Verão e Inverno } \\
\text { bem definidas }\end{array}$ & 5 \\
\hline Glacial (E) & $\begin{array}{l}\text { Estação do Verão pouco definida } \\
\text { ou inexistente, podendo ser } \\
\text { definido com Climas polares e de } \\
\text { alta montanha }\end{array}$ & 9 \\
\hline Não classificado & Ausência de dados & 5 \\
\hline
\end{tabular}

Climas extremos (muito quente e muito frio) podem atuar fortemente no processo degradacional, quando os diversos elementos da natureza têm seus respectivos fluxos de matéria e energia alterados, e por conta disto, atribui-se peso 9 aos climas árido e glacial, ao passo que o peso 1 foi atribuído ao clima tropical por apresentar uma melhor distribuição pluviométrica ao longo do ano. 
Vale salientar que em climas semi-áridos, chuvas com elevado volume, de curta duração, atuam no processo degradacional dos solos, como também, inundações, transportando os materiais geológicos de frações distintas ao longo da drenagem.

A pontuação da tabela 29 foi baseada na distribuição e no volume de chuva, onde os maiores pesos foram atribuídos às distribuições pluviométricas irregulares ao longo do ano.

A classificação climática de Köppen \& Geiger (1928), também se baseia no volume de chuva e na temperatura média, onde cada uma destas questões foram atibuidas pesos, conforme exposto na tabela 30 :

Tabela 30 - Tipo climático local - Köppen-Geiger (PEEL; FINLAYSON; MCMAHON, 2007).

\begin{tabular}{|c|l|c|}
\hline Tipologia & \multicolumn{1}{|c|}{ Precipitação pluviométrica } & Peso \\
\hline S & Precipitação anual total média entre 380 e $760 \mathrm{~mm}$ & 5 \\
\hline W & Precipitação anual total média < 250mm & 8 \\
\hline F & $\begin{array}{l}\text { Ausência de estação seca definida e ocorrência de precipitação } \\
\text { pluviométrica em todos os meses do ano. }\end{array}$ & 1 \\
\hline W & Chuvas de Verão & 9 \\
\hline S & Chuvas de Inverno & 9 \\
\hline w' & Chuvas de Verão-outono & 8 \\
\hline s' & Chuvas de Inverno-outono & 7 \\
\hline M & Precipitação total anual média > 1500mm & 7 \\
\hline T & Precipitação do mês mais seco < 60mm & 8 \\
\hline F & Temperatura média do ar no mês mais quente compreendida entre & 6 \\
\hline M & 0 e $10^{\circ} \mathrm{C}$ & Temperatura média do mês mais quente < $0^{\circ} \mathrm{C}$ \\
\hline
\end{tabular}

$\mathrm{Na}$ tabela 30 a atribuição dos "scores" partiu da seguinte lógica de que, quanto maior ou menor a temperatura, mais extrema é a condição climática. Neste sentido as maiores pontuações ocorreram na tipologia w e s, enquanto a menor ocorreu na tipologia f, por não apresentar momento de estiagem, atribuindo-lhe pontuação com peso 1. 
No caso de ocorrer chuvas em estações bem definidas, como nas tipologias w' e s', atribui-se peso 8 para ambas, pois a interação do clima com os demais elementos geoambientais superfíciais ocorrem de forma fragmentada, como também, decréscimo ou ausência de precipitação, intercalando momentos de significativa capacidade de transporte dos materiais geológicos com a deposição destes produtos no interior das drenagens. Este peso foi atribuído, também, para precipitações inferiores a $250 \mathrm{~mm}$, na tipologia $\mathrm{W}$ e para os locais susceptíveis ao congelamento, como na tipologia $\mathrm{F}$.

Embora este sistema tenha sido focado em ambientes de clima similar ao do Brasil, atribui-se pesos aos demais tipos climáticos, no caso da aplicação do mesmo sob condições climáticas diferentes as do Brasil (tabela 31).

Tabela 31 - Temperatura média - Köppen-Geiger (PEEL; FINLAYSON; MCMAHON, 2007).

\begin{tabular}{|c|l|c|}
\hline Tipologia & \multicolumn{1}{|c|}{ Temperatura média do ar } & Peso \\
\hline $\mathrm{A}$ & Temperatura média do ar no mês mais quente $\geq 22^{\circ} \mathrm{C}$ & 7 \\
\hline $\mathrm{B}$ & Temperatura média do ar no mês mais quente $<22^{\circ} \mathrm{C}$ & 1 \\
\cline { 2 - 3 } & Temperaturas médias do ar nos 4 meses mais quentes $>10^{\circ} \mathrm{C}$ & 7 \\
\hline \multirow{3}{*}{$\mathrm{C}$} & Temperatura média do ar no mês mais quente $<22^{\circ} \mathrm{C}$ & 6 \\
\cline { 2 - 3 } & Temperaturas médias do ar $>10^{\circ} \mathrm{C}$ durante menos de 4 meses & 6 \\
\cline { 2 - 3 } & Temperatura média do ar no mês mais frio $>-38^{\circ} \mathrm{C}$ & 9 \\
\hline $\mathrm{D}$ & Temperatura média do ar no mês mais frio $<-38^{\circ} \mathrm{C}$ & 6 \\
\hline $\mathrm{H}$ & Temperatura média anual do ar $>18^{\circ} \mathrm{C}$ & 9 \\
\cline { 2 - 3 } & $\begin{array}{l}\text { Deserto ou semi-deserto quente (temperatura anual média do ar } \\
\left.\text { igual ou superior a } 18^{\circ} \mathrm{C}\right)\end{array}$ & 6 \\
\hline $\mathrm{K}$ & Temperatura media anual do ar $<18^{\circ} \mathrm{C}$ & \\
\cline { 2 - 3 } & $\begin{array}{l}\text { Deserto ou semi-deserto frio (temperatura anual média do ar } \\
\left.\text { inferior a } 18^{\circ} \mathrm{C}\right)\end{array}$ & \\
\hline
\end{tabular}

Visando facilitar a distribuição dos "scores", os resultados parciais foram agrupados por faixas (baixo, médio e alto), e a partir do somatório das variáveis que compõem os parâmetros climáticos, chegou-se aos valores abaixo (tabela 32): 
Tabela 32 - Pontuação Parcial dos parâmetros climáticos.

\begin{tabular}{|c|c|}
\hline Limite & Classificação parcial \\
\hline $3-14$ & Baixo \\
\hline $15-18$ & Médio \\
\hline $19-27$ & Alto \\
\hline
\end{tabular}

\subsection{Parâmetros Geológicos}

Como a erosão ocorre predominantemente nos solos, atribui-se pontuações distintas, com base na capacidade destes materiais serem degradados pela ação do tempo, bem como, induzir aos processos erosivos no interior do canal, como também, em suas margens.

Através desta lógica, chegou-se aos seguintes pesos: rochas sedimentares (5) por serem, predominantemente mais susceptíveis a degradação mas inferiores aos solos, em comparação com as rochas.

Para as rochas ígneas, atribuiu-se peso 1, por se tratarem de materiais mais resistêntes, enquanto que as litologias classificados como sendo metamórficas obtiverem peso (2), por serem mais resistentes ao desgaste, em comparação comas sedimentares.

Por conta da variação dos diferentes tipos de rochas dentro do mesmo grupo litológico, optou-se por pontuá-los pelo grupo que as mesmas se encontram, como observado na tabela 33.

Tabela 33 - Natureza do substrato.

\begin{tabular}{|l|c|}
\hline \multicolumn{1}{|c|}{ Litologia } & Peso \\
\hline Solo & 8 \\
\hline Depósito sedimentar & 9 \\
\hline Rocha ígnea & 1 \\
\hline Rocha metamórfica & 2 \\
\hline Rocha sedimentar & 5 \\
\hline Contato geológico & 9 \\
\hline
\end{tabular}


$\mathrm{Na}$ tabela 33, considerou-se as rochas ígneas como sendo a mais resistente (peso 1) aos ataques intempéricos (físico, químico e biológico) e a de maior peso a sedimentar (peso 5) pois na grande maioria das vezes estes corpos litológicos são mais susceptíveis aos ataques dos agentes climáticos, mas superiores aos solos e depósitos sedimentares (estágio inicial na formação de rochas sedimentares), onde dentro deste mesmo grupo de rocha ocorre variação entre as espécies litológicas. Embora o tempo de formação exerça uma certa relação quanto à capacidade de serem degradadas, o tempo geológico não foi levada em consideração por questões de ordem técnica, já que as técnicas de datação, além de serem extremamente especializadas e caras, dificultaria uma classificação levando em consideração ao tempo geológico.

No sistema de classificação aqui proposto, definiu-se o peso do tipo de substrato, como sendo peso 1 para as rochas ígneas e peso 9 para os depósitos sedimentares, como observados na tabela 33.

Quanto aos materiais formados a partir da deposição dos solos transportados, estes foram pontuados da seguinte forma: peso 9 para os solos transportados (por serem mais susceptíveis a remobilização e serem péssimos locais para interversão humana), peso 1 para os afloramentos rochosos (Neossolos Litóticos) por serem mais resistentes aos ataques do clima e para os solos residuais jovens (por serem oriundos do processos de intemperismo e não terem sidos totalmente modificados, pode apresentar considerável resistência, embora o solo residual maduro seja fisicamente mais evoluido e menos resistente que o jovem (peso 3), como observado na tabela 34 . 
Tabela 34 - Tipos de solos.

\begin{tabular}{|l|c|}
\hline \multicolumn{1}{|c|}{ Tipo de solo } & Peso \\
\hline Aluvião & 9 \\
\hline Aterro & 6 \\
\hline Ausente & 1 \\
\hline Contato geológico & 9 \\
\hline Depósito sedimentar & 9 \\
\hline $\begin{array}{l}\text { Depósito sedimentar } \\
\text { pedogenisado }\end{array}$ & 5 \\
\hline Orgânico & 5 \\
\hline Paleossolo & 5 \\
\hline Solo residual jovem & 1 \\
\hline Solo residual maduro & 3 \\
\hline Transportado & 9 \\
\hline Neossolo litólico & 1 \\
\hline
\end{tabular}

Os aterros por serem elementos socialmente construidos, podem ser trabalhados para terem uma melhor resistência geomecânica e/ou obras complementares para diminuição dos ricos à degradação, classificou-se tais elementos como peso 6.

Como os solos ricos em matéria orgânica são menos susceptíveis á erosão, como os neossolos argilosos, onde os mesmos foram considerados como tendo peso 5 (resistência intermediária em relação aos solos residuais e aos paleossolos (se foi capaz de sobreviver ao processo natural de degradação e sofre as consequencias da ação do tempo sobre ele e ainda resistir de forma reliquiária), como também os solos formados após a deposição dos materiais geológicos granulares e ação pedogenética (pode apresentar resistência e caracterização física bem variada).

A tabela 35 apresenta as possíveis combinações que definem, inicialmente, os parâmetros geológicos. 
Tabela 35 - Pontuação Parcial dos parâmetros geológicos.

\begin{tabular}{|c|c|}
\hline Limite & Classificação párcial \\
\hline $1-8$ & Baixo \\
\hline $9-13$ & Médio \\
\hline $14-18$ & Alto \\
\hline
\end{tabular}

\subsection{Parâmetros Geomorfológicos}

O tipo de vale está relacionado ao clima local, onde os vales em $U$ ocorrem em local com geleira, atribuindo-se assim, peso 8 por estarem ou estiverem sob ação do gelo e peso 9 aos vales em $V$ e current profile a locais de clima tropical e subtropical, com relevo do tipo, mares de morros e entre vales (tabela 36 ).

Tabela 36 - Tipos de vales fluviais

\begin{tabular}{|c|c|}
\hline Tipologia & Peso \\
\hline $\mathrm{U}$ & 8 \\
\hline $\mathrm{V}$ & 9 \\
\hline Tabular & 7 \\
\hline Irregular & 8 \\
\hline Cruzado & 9 \\
\hline
\end{tabular}

De um modo geral, a tipologia fluvial é apresentada na tabela 37, contendo ainda, suas características gerais e processos morfogenéticos atuantes. 
Tabela 37 - Tipologia fluvial e suas características distintas (adaptado de DOEGLAS, 1962; CUNHA \&

GUERRA, 1996; AHMED \& FAWZI, 2009; BARROS; RAPOSO; MAGALHÃES JÚNIOR, 2009;

WARN, 2011).

\begin{tabular}{|c|l|c|}
\hline Tipo de canal & \multicolumn{1}{|c|}{ Características } & Peso \\
\hline Retilíneo & $\begin{array}{l}\text { Canais verdadeiramente retos são relativamente raros e são } \\
\text { controlados por linhas tectônicas e requerem embasamento } \\
\text { rochoso homogêneo. }\end{array}$ & 3 \\
\hline Meandrante & $\begin{array}{l}\text { São canais sinuosos, largos, harmoniosas e semelhantes entre } \\
\text { si, por devido à escavação na margem com maior velocidade da } \\
\text { corrente. }\end{array}$ & 9 \\
\hline Anastomosados & $\begin{array}{l}\text { Formados em condições especiais relacionados com a carga de } \\
\text { sedimentos do leito, pois quando transporta material grosseiro } \\
\text { em grandes quantidades e não tem potencia para transportar } \\
\text { estes materiais em frações maiores até o nível de base, os } \\
\text { mesmos se depositam no próprio leito. }\end{array}$ & 5 \\
\hline & $\begin{array}{l}\text { As condições requeridas para a formação de rios entrelaçados } \\
\text { são: fonte abundante de sedimentos, variações rápidas e } \\
\text { frequentes no fluxo de água, e presença de bancos erodidos } \\
\text { com materiais não-coesos. Os rios entrelaçados são } \\
\text { encontrados, comunente, em áreas de clima temperado e em } \\
\text { áreas de vales montanhosos, apresentando as seguintes } \\
\text { características: canais em constante mutação, lagos e barras } \\
\text { fluviais. }\end{array}$ & \\
\hline
\end{tabular}

A partir deste conteúdo, definiu-se os pesos de acordo com a inclinação do terreno (tabela 38), onde o maior peso foi atribuído a faixa entre 20 a 45\% (peso 9) pelo falto dos processos erosivos serem mais atuantes nesta faixa e o menor peso foi atribuído à superfície plana, posto que a forma do "maciço" está sujeito ao acumulo de água.

Tabela 38 - Grau de Inclinação (EMBRAPA, 1979).

\begin{tabular}{|l|c|c|}
\hline \multicolumn{1}{|c|}{ Tipologia } & Inclinação (\%) & Peso \\
\hline Plana & $0-3$ & 1 \\
\hline Suave Ondulada & $4-8$ & 5 \\
\hline Ondulada & $9-20$ & 7 \\
\hline Muito Ondulada & $21-45$ & 9 \\
\hline Forte Ondulada & $46-75$ & 8 \\
\hline Uso Restrito & $>76$ & 6 \\
\hline
\end{tabular}


Através da NBR 11682 (2006), classificou-se os diferentes tipos de vertentes, onde as superícies retilíneas (aplainadas) atribui-se peso 1 a mesma, ao passo que nas convexas, peso 9 por apresentar mais vulnerabilidade aos problemas geotécnicos (tabela 39).

Tabela 39 - Tipo de vertentes (adaptado de NBR 11682, 2006).

\begin{tabular}{|l|c|}
\hline \multicolumn{1}{|c|}{ Tipologia } & Peso \\
\hline Convexa & 9 \\
\hline Côncava & 5 \\
\hline Convexa-Côncava & 6 \\
\hline Côncava-Convexa & 3 \\
\hline Retilínea & 1 \\
\hline
\end{tabular}

$\mathrm{Na}$ tabela 40 encontra-se a pontuação parcial relacionada ao somatório das variáveis que compõem os parâmetros geomorfológicos.

Tabela 40 - Pontuação Parcial dos parâmetros geomorfológicos.

\begin{tabular}{|c|c|}
\hline Limite & Classificação párcial \\
\hline $12-22$ & Baixo \\
\hline $23-26$ & Médio \\
\hline $27-36$ & Alto \\
\hline
\end{tabular}

\subsection{Parâmetros Hidráulicos}

Conforme a dinâmica climática de uma determinada região atua, sua atuação irá influenciar na dinâmica dos rios, já que os cursos d'águas podem estar sujeitos à variabilidade de seu volume hídrico, setorizados entre a quadra chuvosa e estiagem, refletindo assim, na variação da área alagada do canal e na capacidade de modificação do meio.

Por conta disto, a maior pontuação foi dada ao regime perene, por conta da capacidade de escoamento constante (peso 9) e transformação do meio circundante, isto visto como elemento da paisagem agindo isoladamente, ao passo que o menor peso foi atribuído ao regime irregular, em função da variabilidade na 
distribuição das chuvas ao longo do ano (tabela 41), embora problemas diversos podem ocorrer em ambos or regimes, de acordo com as condições do meio físico.

Tabela 41 - Tipo de regime.

\begin{tabular}{|c|c|}
\hline Tipologia & Peso \\
\hline Perene & 9 \\
\hline Intermitente & 7 \\
\hline Irregular & 5 \\
\hline Caótico & 6 \\
\hline
\end{tabular}

A vazão atua transportando os diferentes materiais geológicos ao longo da lâmina d'água (o transporte em saltação, tração, rolamento e suspensão dependem das características dos sedimentos, altura da lâmina d'água e da vazão do rio), podendo agir no processo erosivo do canal.

Como se observa, a vazão e aporte de sedimentos estão correlacionados entre sí e variam amplamente entre os rios (as condições geológico-geotécninas influenciam neste processo de carreamento rio abaixo), em especial nos de grandes dimensões, como exemplificado na tabela 18 e a partir desta discrepância entre as diferentes drenagens, chegou-se aos seguintes pesos (tabela 42):

Tabela 42 - Vazão $\left(\mathrm{m}^{3} / \mathrm{s}\right)$.

\begin{tabular}{|l|c|c|}
\hline \multicolumn{1}{|c|}{ Grau } & Variação $\left(\mathbf{m}^{3 / \mathbf{s}}\right)$ & Peso \\
\hline Muito baixa & $\leq 1$ & 8 \\
\hline Baixa & $1-100$ & 7 \\
\hline Normal & 500 & 5 \\
\hline Alta & 1.000 & 8 \\
\hline Muito alta & $\geq 10.000$ & 9 \\
\hline Ausência de vazão/ estiagem & - & 9 \\
\hline Não mensurado & - & 5 \\
\hline
\end{tabular}

No ciclo hidrológico, as águas chegam ao interior dos rios e demais reservatórios pela precipitação pluviométrica, bem como, pelas nascentes, que 
tangenciam o nivel freático, cuja fonte está nos intertícios do solo e demais depósitos sedimentares, podendo ocorrer no interior das rochas fraturadas.

Neste caso, a existência de nascente é negativo, do ponto de vista degradacional, onde atribuiu-se pontuação elevada, quando a mesma ocorre na área da drenagem e em local com contato geológico (9), desgastando os materiais das encostas, no caso de margens com inclinação superiores a $4^{\circ}$, ao passo que peso foi atribuído peso 1 aos locais com ausência de nascentes.

No caso de não se observar a nascente, no caso de existir barreiras no local (naturais ou artificiais), sugere-se a atribuição de peso 5, no caso de se ficar em dúvida de ocorrencia, como mostra a tabela 43.

Vale comentar que o papel da nascente neste processo está associado à sua vazão, condição geológico-geotécnica do maciço, tipo de uso e ocupação, bem como, presença de zona ripária.

A figura 7 mostra uma das nascentes que ocorre na margem direita da área de estudo, onde provavelmente, contribui para a remoção do material geológico constituinte da margem, onde esta água que sai do interior do maciço terroso em conjunto com o deslocamento da água do canal contribui para que a remoção do material geológico de suas márgens, soma-se a isso a vazão da drenagem que é baixa.

Nas proximidades deste mesmo local ocorre ainda mais três nascentes, em direção ao anfiteatro, em posições distintas em seu interior, contendo um depósito de encosta (talus), com solos coluviais hidromorfizados.

Tabela 43 - Ocorrência de nascente.

\begin{tabular}{|c|c|}
\hline Tipologia & Peso \\
\hline Ausente & 1 \\
\hline Presente & 9 \\
\hline Não observado & 5 \\
\hline
\end{tabular}

O procedimento de coleta das amostras de água para definição dos sólidos em suspensão foi feito na profundidade média do canal/trecho, onde classificou-se 
como peso mínimo (1) as amostras coletadas com percentual de até $9 \%$ e máxima de 9 pontos para aquelas com valor a partir de 50\%, como se observa na tabela 44 .

Partiu-se da seguinte lógica: quanto maior o conteúdo coletado por amostra, maior é o processo de disposição dos materiais no entorno e/ou no próprio canal.

Vale salientar que é necessário que em cada ponto de coleta seja feita em tréplica ou duplicadamente, por local de amostragem, cujo frasco de armazenamento deve ser de $500 \mathrm{ml}$, segundo recomendação do Guia de Práticas Sedimentométricas da ANEEL (2000).

Assim como, definir o teor de sedimentos totais, é impressindível na análise hidrossedimentológica, bem como, na investigação sobre os processos erosivos da própria drenagem.

Sendo assim, considerou-se com peso 9 (muito alta) os sedimentos retidos, cujo valor foi superior a $49 \%$ e peso 1 , os que se encontrarem entre 0 a $4 \%$.

Tabela 44 - Sólidos em suspensão (\% de sedimento/ 500ml)

\begin{tabular}{|l|c|c|}
\hline \multicolumn{1}{|c|}{ Tipologia (\%) } & Parâmetro (\%) & Peso \\
\hline Muito baixa & $0-4$ & 3 \\
\hline Baixa & $5-9$ & 5 \\
\hline Normal & $10-24$ & 9 \\
\hline Alta & $25-49$ & 5 \\
\hline Muito alta & $\geq 50$ & 5 \\
\hline Não mensurado & - & 1 \\
\hline
\end{tabular}

A partir do somatório da pontuação das variáveis hidráulicas, chegou-se aos seguintes limites, como observados na tabela 45.

Tabela 45 - Pontuação Parcial dos parâmetros hidráulicos.

\begin{tabular}{|c|c|}
\hline Limite & Grau de influência \\
\hline $12-21$ & Baixo \\
\hline $22-27$ & Médio \\
\hline $28-36$ & Alto \\
\hline
\end{tabular}




\subsection{Parâmetros Pedológicos e Geotécnicos}

Como os solos ricos em areia são mais susceptíveis à erosão (SOUZA; GASPARETTO; NAKASHIMA, 2008), foi atribuído o peso máximo (9) a estes tipos de texturas: arenosa, silto-arenosa, areno-siltosa e, a de menor peso, a argilosa (peso 5) por apresentar baixo potencial erosivo devido à coesão, como observado na tabela 46.

Tabela 46 - Textura dos solos (granulometria).

\begin{tabular}{|l|c|}
\hline \multicolumn{1}{|c|}{ Tipologia } & Peso \\
\hline Arenosa & 9 \\
\hline Areia franca & 8 \\
\hline Areia siltosa & 9 \\
\hline Franco arenoso & 7 \\
\hline Franco argilosa-arenoso & 7 \\
\hline Franco argilosa & 5 \\
\hline Areia argilosa & 8 \\
\hline Argilosa & 5 \\
\hline Argila siltosa & 8 \\
\hline Franco argilo-siltoso & 6 \\
\hline Franco siltoso & 6 \\
\hline Siltoso & 6 \\
\hline Silte arenoso & 9 \\
\hline Franco & 5 \\
\hline Não quantificado & 5 \\
\hline
\end{tabular}

A permeabilidade é uma propriedade que está relacionada à capacidade de um determinado solo armazenar água em seu interior. Quando saturado, o solo fica sujeito à problemas geotécnico o que sugeriu à seguinte classificação/ pontuação (tabela 47): 
Tabela 47 - Permeabilidade dos solos (adaptado de STANCATI; NOGUEIRA; MONJEVILAR, 1981 apud LORANDI et al., 2001).

\begin{tabular}{|l|c|c|}
\hline \multicolumn{1}{|c|}{ Tipo de solo } & Parâmetro $(\mathrm{cm} / \mathbf{s})$ & Peso \\
\hline Praticamente Impermeável & $<10^{-1} \mathrm{~cm} / \mathrm{s}$ & 7 \\
\hline Muito Baixa & $10^{-5} \mathrm{a} 10^{-1} \mathrm{~cm} / \mathrm{s}$ & 5 \\
\hline Baixa & $10^{-3} \mathrm{a} 10^{-5} \mathrm{~cm} / \mathrm{s}$ & 3 \\
\hline Média & $10^{-1} \mathrm{a} 10^{-3} \mathrm{~cm} / \mathrm{s}$ & 1 \\
\hline Alta & $<10^{-1} \mathrm{~cm} / \mathrm{s}$ & 5 \\
\hline Não quantificado & - & \\
\hline
\end{tabular}

Visando facilitar e padronizar o percentual das variáveis, quando na ausência de parâmetros pré-definidos por normas técnicas aplicadas aos ambientes fluviais, adotou-se como peso 1 a faixa percentual entre 0 a 4 , no caso em questão sobre o teor de matéria orgânica (quantidade de sedimentos/volume da amostra * 100) e peso 9 , os valores acima de $50 \%$, como se observa na tabela 48 .

Este teor de matéria orgânica está relacionado aos sedimentos provenientes dos solos localizados nas margens dos rios (planície fluvial).

Tabela 48 - Teor de matéria orgânica dos solos.

\begin{tabular}{|l|c|c|}
\hline \multicolumn{1}{|c|}{ Tipologia (\%) } & Matéria Orgânica (\%) & Peso \\
\hline Muito baixa & $0-4$ & 9 \\
\hline Baixa & $5-9$ & 7 \\
\hline Normal & $10-24$ & 5 \\
\hline Alta & $25-49$ & 3 \\
\hline Muito alta & $\geq 50$ & 1 \\
\hline Não mensurado & - & 5 \\
\hline
\end{tabular}

Após a adoção das faixas propostas pela IAEG (1978) para o grau de saturação dos sedimentos, atribui-se peso 9 aos valores extremos (naturalmente seco e saturado), já que em ambos os casos, influenciam no desenvolvimento de problemas geotécnico como a erosão, na área correspondente à faixa marginal e ao leito maior, definindo-o com peso 1 ao sedimento úmido como o ideal (tabela 49). 
Tabela 49 - Grau de Saturação dos materiais geológicos (adaptado de IAEG, 1979).

\begin{tabular}{|l|c|c|c|}
\hline \multicolumn{1}{|c|}{ Tipo de solo } & Grau de Saturação (\%) & Classe & Peso \\
\hline Naturalemente seco & $0-24$ & 1 & 9 \\
\hline Úmido & $25-49$ & 2 & 1 \\
\hline Muito úmido & $50-79$ & 3 & 5 \\
\hline Altamente saturado & $80-94$ & 4 & 7 \\
\hline Saturado & $95-100$ & 5 & 9 \\
\hline Não mensurado & & 5 \\
\hline
\end{tabular}

O cálculo do grau de saturação é feito a partir da seguinte fórmula:

$\mathrm{h}=\underline{\mathrm{Ph}-\mathrm{PS}} \times 100$

Ps

onde: $\mathrm{h}=$ umidade natural; $\mathrm{Ph}=\mathrm{Peso}$ úmido; $\mathrm{Ps}=$ Peso seco.

Por conta de todas estas questões, atribui-se os seguintes pesos aos problemas de natureza geotécnicas (ver tabela 29), onde a grande maioria destas tipologias foi atribuida peso 9, exceto por queda de blocos (peso 6), por ocorrer apenas em taludes rochosos, no caso, em drenagens localizadas no interior dos maciços rochosos e são pontuais no interior do canal e margens, onde a correção ou minimização deste problema é relativamente fácil de ser feita (concreto projetado, curtina atirantada e murro de arrimo).

Por outro lado, em áreas altamente urbanizadas, em decorrência das ações humanas, estão sujeitos aos eventos de inundações (MORELLI et al., 2012) como também de enchentes (MINISTÉRIO DAS CIDADES, 2007) e por conta disto, atribuise peso 9 para este último problema, já que os danos e prejuizos relacionados a isto são bem maiores, embora sua frequencia é normalmente menor, que os das inundações (peso 8), como se observa na tabela 50. 
Tabela 50 - Problemas geotécnicos.

\begin{tabular}{|l|c|}
\hline \multicolumn{1}{|c|}{ Tipologia } & Peso \\
\hline Assoreamento & 9 \\
\hline Ausente & 1 \\
\hline Compactação dos solos & 5 \\
\hline Enchente & 9 \\
\hline Erosão linear & 7 \\
\hline Erosão por Piping & 8 \\
\hline Fluxo de detritos & 9 \\
\hline Inundações & 8 \\
\hline Mixto & 9 \\
\hline Outros & 5 \\
\hline Presença de cunha & 8 \\
\hline Queda de blocos & 6 \\
\hline Ravina & 8 \\
\hline Recalque & 9 \\
\hline Ruptura de talude & 7 \\
\hline Solapamento basal & 8 \\
\hline Tombamento & 8 \\
\hline Voçoroca & 9 \\
\hline
\end{tabular}

A partir dos dados apresentados nas tabelas que compõem estes parâmetros, e atribuídos os diferentes pesos a estas variáveis, chegou-se às faixas de valores e seus graus de influência, como mostrado na tabela 51( baseados nos parâmetros geotécnicos sugeridos).

Tabela 51 - Pontuação Parcial dos parâmetros geotécnicos.

\begin{tabular}{|c|c|}
\hline Limite & Grau de influência \\
\hline $9-32$ & Baixo \\
\hline $33-37$ & Médio \\
\hline $38-45$ & Alto \\
\hline
\end{tabular}




\subsection{Parâmetros Ecológicos}

Foram propostos cinco parâmetros ecológicos relacionados ao espaço da faixa marginal, os quais serão discutidos a partir de agora.

Nesta tese, adotou-se a distância regida pela Lei no 4.771 (1965) que trata da faixa marginal, além desta incrementamos $100 \mathrm{~m}$ em ambos os lados.

O papel que a faixa marginal exerce já foi mostrado anteriormente e por conta disto, atribui-se peso 1 para as drenagem que apresentem matas ciliares, independendo do domínio morfoclimático onde o curso d'água esteja inserido e peso 9 para os locais com ausência das mesmas, posto que estes corpos vegetacionais exercem papeis importântes para minimizar o processo de erosão (tabela 52).

Tabela 52 - Faixa marginal (mata ciliar).

\begin{tabular}{|l|c|}
\hline \multicolumn{1}{|c|}{ Tipologia } & Peso \\
\hline Presente & 1 \\
\hline Ausente & 9 \\
\hline
\end{tabular}

Devido a estas questões, definiu-se que as matas ciliares, quando contínuas ao longo da drenagem, teriam peso 1; ao passo de que, quando ausente, peso 9, por facilitar o escoamento superficial e a aumento da susceptibilidade a erosão dos solos destes locais e da própria vertente (tabela 53). Neste caso, a lógica foi: quanto mais a contínua a faixa marginal, menor será a susceptibilidade de degradação de suas margens.

Tabela 53 - Característica da faixa marginal (mata ciliar).

\begin{tabular}{|l|c|}
\hline \multicolumn{1}{|c|}{ Tipologia } & Peso \\
\hline Continua & 1 \\
\hline Descontínua & 7 \\
\hline Irregular & 6 \\
\hline Ausente & 9 \\
\hline
\end{tabular}

Devido a capacidade que a vegetação tem de atuar no amortecimento do impacto das gostas das chuvas nos solos, atribui-se peso 1 a vegetação do tipo 
arbórea, por apresentar maior área da copa e no outro extremo, locais desmatados, expõem diretamente o solo aos efeitos das intempéries - efeito "splash" (peso 9), como observado na tabela 54, embora possa ocorrer o efeito de bordas (ZAÚ; COELHO NETTO; OLIVEIRA, 2007).

Tabela 54 - Aspecto vegetacional da mata ciliar.

\begin{tabular}{|l|c|}
\hline \multicolumn{1}{|c|}{ Tipologia } & Peso \\
\hline Arbórea & 1 \\
\hline Arbustiva & 6 \\
\hline Reflorestada & 5 \\
\hline Desmatada & 9 \\
\hline
\end{tabular}

Sendo assim, pontuou-se o porte vegetacional onde a mesma está localizada, aí atribuiu-se peso 1 para as fixas, já que seu sistema radicular, quando profundo, contribui para que a ação da água seja amenizada no processo de erosão de suas margens. As flutuantes atribui-se peso 5 pois amortecem, de certa forma a massa líquida em escoamento, embora quando localizadas em ambientes ricos em nutrientes, podem comprometer a qualidade da água, sendo assim, nocivas ao meio, apesar de certa forma agirem como barreiras naturais retentoras de metais pesados (macrófitas). A ausência de vegetação, tanto nas margens quanto no canal, comprometeria a estabilidade do canal fluvial e por conta disto, atribui-se peso 9 , como se observa na tabela 55 .

Tabela 55 - Tipo de vegetação na drenagem (fixação ao leito).

\begin{tabular}{|l|c|}
\hline \multicolumn{1}{|c|}{ Tipologia } & Peso \\
\hline Fixa & 1 \\
\hline Flutuante & 5 \\
\hline Mista & 3 \\
\hline Ausente & 9 \\
\hline
\end{tabular}

Quanto ao tipo de cobertura do solo que existe no interior das matas ciliares, atribuiu-se peso 1 àquelas que apresentam serrapilheira em seu interior, e quando ausente, peso 9, como observado na tabela 35. Quando em áreas urbanizadas, as 
áreas com vegetação podem apresentar solos compactados devido ao pisoteio (humano/animal) ou mesmo ter seu solo impermeabilizado por materiais que dificultem ou não a infiltração de água no interior do solo, como por exemplo, uso de concreto, sendo normalmente observados em áreas urbanizadas (tabela 56).

Tabela 56 - Cobertura do solo da mata cilitar.

\begin{tabular}{|l|c|}
\hline \multicolumn{1}{|c|}{ Tipologia } & Peso \\
\hline Solo com serrapilheira & 1 \\
\hline Solo exposto & 9 \\
\hline Material compactado & 8 \\
\hline Outros materiais - permeáveis & 5 \\
\hline Outros materiais - impermeáveis & 9 \\
\hline
\end{tabular}

Com base nos parâmetros apresentados, construiu-seuma tabela de pontuação parcial, como mostra a tabela 57 , para os espaços destinados aos seus leitos fluviais (menor, maior e excepcional).

Tabela 57 - Pontuação Parcial dos parâmetros ecológicos.

\begin{tabular}{|c|c|}
\hline Limite & Grau de influência \\
\hline $5-16$ & Baixo \\
\hline $17-27$ & Médio \\
\hline $28-45$ & Alto \\
\hline
\end{tabular}

\subsection{Parâmetros relacionados ao uso e ocupação do solo}


Conforme o papel do uso e ocupação humano ao longo das planícies fluviais e seus respectivos impactos apresentados na revisão bibliográfica pertinente a este tema (ver tópico 4.2.7), atribuiu-se pesos distintos às diferentes obras de engenharia posicionadas próximas ou construídas diretamente no interior dos corpos hídricos, a saber, pontes com fundações nas margens e/ou no interior do canal (erosão nas margens e assoreamento próximo aos pilares), viadutos e estradas, pavimentadas obtiveram peso 9, ao passo que, os túneis, peso 3 , e peso 1 para os segmentos onde tais infra-estruturas são ausentes. Apesar dos "benefícios" que tais obras geram para toda sociedade civil, não se pode dizer que isto valha para os outros elementos da natureza pois, modificando fortemente seus habitats, causam problemas diversos.

Considera-se como outras (construções), as infra-estruturas que não foram citadas aqui e por conta da ampla diversidade adotada pela engenharia civil, cujos danos ao meio são diversificados e ampliados. Portanto, para se ter uma margem de erro menor, adotou-se peso 5 (tabela 58).

Tabela 58 - Infra-estruturas públicas e privadas

\begin{tabular}{|l|c|}
\hline \multicolumn{1}{|c|}{ Tipologia } & Peso \\
\hline Ausente & 1 \\
\hline Duto/ tubulação & 7 \\
\hline Estrada de terra & 8 \\
\hline Estrada em paralelepípedo & 6 \\
\hline Estrada pavimentada & 9 \\
\hline Galeria pluvial & 5 \\
\hline Outras construções & 5 \\
\hline Ponte com fundação nas margens & 9 \\
\hline Ponte com fundação no canal & 9 \\
\hline Túnel & 3 \\
\hline Viaduto & 9 \\
\hline
\end{tabular}

Devido aos diversos impáctos que ocorrem pelas atividades sócio-econômicas já expostas, definiu-se os pesos relacionados às diferentes formas de utilização e seus impactos gerados ao meio físico, com ênfase na degradação dos solos e sua repercursão aos recursos hídricos, como observados na tabela 59. 
Tabela 59 - Tipo de uso e ocupação

\begin{tabular}{|l|c|}
\hline \multicolumn{1}{|c|}{ Tipologia } & Peso \\
\hline Agricultura & 7 \\
\hline Área natural & 1 \\
\hline Hidrovia & 5 \\
\hline Industrial & 7 \\
\hline Lazer & 6 \\
\hline Mineração & 9 \\
\hline Misto & 9 \\
\hline Outros & 5 \\
\hline Pastagem & 9 \\
\hline Urbano & 7 \\
\hline
\end{tabular}

Como mostrado na tabela 59, as atividades consideradas mais impactantes foram atribuídas peso 9, por exemplo: as áreas de pastagens, nas quais a pressão exercida pela pata de diferentes animais degradam 0 solo, tornando-os impermeáveis, sujeitos à ação do tempo; mineração e uso misto (mais de uma atividade econômica); $O$ menor peso foi atribuído às áreas consideradas naturais, com ausência de práticas sociais, com vegetação primária ou secundária do próprio local.

No caso do uso ser feito por outras atividades sócio-econômicas não listadas e pontuadas aqui, sugeriu-se a adoção de peso 5 para as mesmas.

Com relação à força exercida pelos diferentes animais, no caso do uso do solo para pastagem, atribui-se pesos distintos conforme a relação entre a área média dos cascos em comparação com a do trator, incluindo ainda o peso atribuído à estas variáveis, onde o peso máximo foi definido ao bovino (peso 9) e mínimo em caprino e muar (peso 5), como se observa na tabela 60.

Segundo Sousa, Silva e Resende (1998) a força exercida pelo pisoteio dos animais, além de variar entre si, o boi, por exemplo, exerce uma força $106,5 \%$ maior que aquela exercida pelo trator, e por isso definiu-lhe peso 9 . 0 menor peso (5) foi atribuído à mula e cabra, como se observa na tabela 60, embora em regiões do nordeste, as cabras exercem um forte papel na degradação de encostas. 
Tabela 60 - Valores da massa, área do casco e pressão de animais (adaptado de SOUSA et al., 1998 apud SOUSA et al., 1998).

\begin{tabular}{|l|c|c|c|c|c|}
\hline \multicolumn{1}{|c|}{ Animal } & $\begin{array}{c}\text { Área média do } \\
\text { casco }\left(\mathbf{m}^{\mathbf{2}} \mathbf{)}\right.\end{array}$ & $\begin{array}{c}\text { Peso médio } \\
\mathbf{( k g})\end{array}$ & $\begin{array}{c}\text { Pressão } \\
\mathbf{( K p a )}\end{array}$ & $\begin{array}{c}\text { Porcentagem } \\
(\%)\end{array}$ & Peso \\
\hline Bovino & 0,103 & 400 & 190,3 & 100 & 9 \\
\hline Novilho & 0,0057 & 200 & 171,9 & 90 & 7 \\
\hline Bezerro & 0,0018 & 60 & 163,3 & 86 & 6 \\
\hline Equino & 0,0076 & 250 & 161,2 & 85 & 5 \\
\hline Caprino & 0,0016 & 35 & 107,2 & 56 & 5 \\
\hline Muar & 0,0038 & 120 & 154,7 & 81 & 6 \\
\hline Asinino & 0,0030 & 100 & 163,3 & 86 & 6 \\
\hline
\end{tabular}

Quando o local onde for aplicado o sistema de avaliação for contínuo, pertencente a mesma propriedade, é sugerido adotar o mesmo valor da relação número de animais versus hectare nos formulários aplicados em um determinado lugar, como foi o caso desta tese.

Embora ocorra um elevado número de animais em uma área relativamente grande, na mesma propriedade e se o número de animais encaixa-se com peso inferior, não implica que problemas oriundos do caminhamento destes não ocorram ao longo da área, mas sim, em um espaço físico, possivelmente menor.

Pensando nisto, criou-se a relação entre o número de animais por hectare, como exposto na tabela 61 , onde o maior peso foi atribuído ao boi inserido em uma área de tamanho igual ou superior a 100 hectares. 
Tabela 61 - NÚMERO de animais por hectare.

\begin{tabular}{|c|c|c|c|c|c|c|}
\hline \multirow[t]{2}{*}{ Tipologia } & \multicolumn{5}{|c|}{$\mathrm{N}^{\circ}$ de animais } & \multirow{12}{*}{$\begin{array}{l}\text { D } \\
\mathbb{D} \\
0\end{array}$} \\
\hline & 1 & 5 & 10 & 50 & $\geq 100$ & \\
\hline Bovino & 5 & 6 & 7 & 8 & 9 & \\
\hline Novilho & 3 & 4 & 5 & 6 & 7 & \\
\hline Bezerro & 2 & 3 & 4 & 5 & 6 & \\
\hline Equino & 2 & 3 & 4 & 5 & 6 & \\
\hline Caprino & 1 & 2 & 3 & 4 & 5 & \\
\hline Muar & 1 & 2 & 3 & 4 & 5 & \\
\hline Asinino & 2 & 3 & 4 & 5 & 6 & \\
\hline Outros & 5 & 5 & 5 & 5 & 5 & \\
\hline Ausente & \multicolumn{5}{|c|}{1} & \\
\hline № de animais & 1 & 5 & 10 & 50 & $\geq 100$ & \\
\hline
\end{tabular}

Partindo desta lógica, atribuiu-se peso 9 à pastagem quando operada de forma livre, por conta dos impactos causados ao solo, enquanto nos locais sem pastagens seu peso corresponde a 1, conforme exposto na tabela 62.

Tabela 62 - Tipo de pastagem.

\begin{tabular}{|c|c|}
\hline Tipologia & Peso \\
\hline Livre & 9 \\
\hline Confinada & 5 \\
\hline Mista & 7 \\
\hline Ausente & 1 \\
\hline
\end{tabular}

Como as práticas conservacionistas fazem parte das medidas mitigadoras e de planejamento do manto de intemperismo, atribui-se peso 1 quando for realizada/presente e quando na ausência destas, definiu-se como sendo de peso 9, conforme exposto na tabela 63. 
Tabela 63 - Planejamento do uso do solo.

\begin{tabular}{|l|c|}
\hline \multicolumn{1}{|c|}{ Tipologia } & Peso \\
\hline Presente & 1 \\
\hline Ausente & 9 \\
\hline
\end{tabular}

A tabela 64 apresenta os diferentes tipos de infra-estruturas que podem ser usadas no controle de problemas geotécnicos, com o propósito de amenizar ou mesmo aumentar o reforço do terreno, como no uso de concreto projetado ou mesmo, muro de contenção, ou cortina atirantada e coluna de Jet grouting, incluindo ainda, o uso de piscinões na diminuição de inundação, os quais são usados, normalmente, em áreas urbanas com alta susceptibilidade de inundações.

Tabela 64 - Infra-estruturas pra controle de erosão

\begin{tabular}{|l|c|}
\hline \multicolumn{1}{|c|}{ Tipologia } & Peso \\
\hline Piscinão & 5 \\
\hline Estruturas em rocha (gabião) & 5 \\
\hline Estruturas em solo (aterro) & 6 \\
\hline Muro de contenção & 3 \\
\hline Cortina atirantada & 3 \\
\hline Concreto projetado & 3 \\
\hline Coluna de Jet grouting & 3 \\
\hline Ausente de infra-estrutura & 9 \\
\hline Sem erosão & 1 \\
\hline
\end{tabular}

Neste sentido, atribuiu-se peso 9 aos locais onde estes problemas existam mas não foi feito nenhum tipo de controle ou prática minimizadora, ao passo que as técnicas de reforço dos maciços (terrosos e rochosos) obtiveram menor peso por conta da pontualidade deste no terreno (peso 3), além disso, são feitas, quando necessário, nas proximidades de barragens, durante a fase de construção, visando diminuir os riscos de problemas geológico-geotécnicos neste tipo de empreendimento (tabela 64).

Com relação à prática de manejo do solo, no caso dos locais que se encontram na área de influência do rio, a adoção de técnicas mitigadoras voltadas a minimizar os impactos causados pelo uso pelo cultivo agrícola foram pontuadas, onde atribui- 
se peso 9 as culturas perenes (causando o empobrecimento do solo mais acelerado e tornando-o vulnerável à degradação), enquanto que a adoção de técnicas de manejo melhoram ou mesmo diminuem os riscos de erosão do solo, como por exemplo, o uso de cordão de vegetação, cultivo em faixa ou mesmo a variação de diferentes técnicas de manejo (misto), que neste caso, atribuiu-se peso 3, como observado na tabela 65.

Tabela 65 - Tipo de Manejo (VIEIRA et al., 1996; BANCO DO NORDESTE, 1999; BERTONI \& LOMBARDI NETO, 1999;).

\begin{tabular}{|c|c|c|}
\hline Tipologia & Impacto & Peso \\
\hline Cultivo anual & $\begin{array}{l}\text { Aumento de pragas e doenças nos cultivos fixos/anuais, } \\
\text { requerem a adoção de cordões de vegetação permanente } \\
\text { para diminuir a erosão do solo, já que desgastam os solos o } \\
\text { cultivo anual (por exemplo: café, cacau e pomar) }\end{array}$ & 9 \\
\hline $\begin{array}{ll}\text { Cordões } & \text { de } \\
\text { vegetação } & \\
\text { permanente } & \\
\end{array}$ & $\begin{array}{l}\text { Auxilia minimizando os dados provocados pelas culturas } \\
\text { anuais, onde estas faixas apresentam-se densas e perenes, } \\
\text { controlando os efeitos da erosão nos solos }\end{array}$ & 3 \\
\hline Rotação de cultura & $\begin{array}{l}\text { Aumenta o conteúdo de matéria orgânica, auxilia no controle } \\
\text { de ervas daninhas }\end{array}$ & 5 \\
\hline Cultivo em faixa & $\begin{array}{l}\text { Distribui melhor as culturas, podendo ter suas posições } \\
\text { fixadas ou móveis no interior da propriedade, cujas faixas } \\
\text { podem estar niveladas, paralelas ou associadas as paraleas e } \\
\text { niveladas. Proteje o terreno, diminuição do volume e } \\
\text { velocidade de enxurradas provocadas por culturas mais } \\
\text { abertas. Ameniza os efeitos da erosão eólica quando feito } \\
\text { perpedndicularmente à direção dos ventos predominantes }\end{array}$ & 3 \\
\hline Ausente & $\begin{array}{l}\text { No caso do solo ser usado para atividades agrícolas e } \\
\text { pastagem, com ausência de qualquer forma de manejo }\end{array}$ & 9 \\
\hline Sem cultivo & $\begin{array}{l}\text { No caso de áreas naturais, sem interferência direta do } \\
\text { homem, como em áreas preservadas. }\end{array}$ & 1 \\
\hline Misto & $\begin{array}{l}\text { Dependendo do tipo de cultura e das condições do terreno, o } \\
\text { uso de mais de uma técnica de manejo ameniza os danos } \\
\text { causados pelo uso do solo }\end{array}$ & 3 \\
\hline Outros & $\begin{array}{l}\text { Consideram-se como outros as técnicas que não foram } \\
\text { comentadas e atribui-se peso } 5 \text { a estas, incluindo calagem do } \\
\text { solo, que melhora o pH do solo }\end{array}$ & 5 \\
\hline Outros & $\begin{array}{l}\text { Consideram-se como outros as técnicas que não foram } \\
\text { comentadas e atribui-se peso } 5 \text { a estas, incluindo calagem do } \\
\text { solo, que melhora o pH do solo }\end{array}$ & 5 \\
\hline $\begin{array}{l}\text { Defensivos } \\
\text { agrícolas }\end{array}$ & $\begin{array}{l}\text { Sob certas condições, é feito o uso de defensivos agrícolas, } \\
\text { onde a calagem é feita para melhor o pH dos solos. } \\
\text { Praguicidas e fungicidas são usado no controle de pragas nas } \\
\text { plantações, contudo, os impactos gerados pelo uso de tais } \\
\text { técnicas e as demais não citadas, diz respeito à contaminação } \\
\text { de água e sedimentos e modificação biogeoquíma destes } \\
\text { materiais }\end{array}$ & 5 \\
\hline
\end{tabular}


Por outro lado, o baixo grau de inclinação nos terrenos aplainados foi atribuído peso 1 , pois dificulta o escoamento das águas provenientes das chuvas, embora, sob certas condições, possa acumular água, quando na ocorrência de depressões em seu interior ou de variações ao longo da "rampa", como observado na tabela 66.

Tabela 66 - Localização do cultivo agrícola na planície fluvial.

\begin{tabular}{|l|c|}
\hline \multicolumn{1}{|c|}{ Tipologia } & Peso \\
\hline Ausente & 1 \\
\hline Em área alagada & 3 \\
\hline Em curva de nível & 5 \\
\hline Em declive & 9 \\
\hline Em faixa & 5 \\
\hline Em planície & 1 \\
\hline Em terraço & 3 \\
\hline Sem cultivo & 1 \\
\hline
\end{tabular}

Os terrenos classificados como tendo declividade variando de suave ondulada a forte ondulada, incluindo os locais com declividade superior a $75^{\circ}$, como mostrado anteriormente, tornam-se vulneráveis à erosão hídrica, atribuindo-se peso 9 as culturas plantadas seguindo a inclinação do terreno, já que o espaçamento entre as plantações favorecerem a canalização do fluxo hídrico, ao ponto de criar feições erosivas, tais como erosão linear (tabela 66).

Tomando-se como base o estudo feito por Bertoni \& Lombardi Neto (1999), Pons (2006) apud Cereda Junior (2006), atribui-se pesos distintos em diferentes tipos de culturas agrícolas, conforme apresentado na tabela 67.

Sendo assim, atribui-se peso 9 para a cultura do feijão, ao passo que o menor valor foi atribuído à cana de açúcar (ver tabela 67). 
Tabela 67 - Tipo de cultura (adaptado de BERTONI \& LOMBARDI NETO, 1999; PONS, 2006 apud CEREDA JUNIOR, 2006).

\begin{tabular}{|l|c|}
\hline \multicolumn{1}{|c|}{ Tipologia } & Peso \\
\hline Arroz & 6 \\
\hline Ausente & 5 \\
\hline Banana & 5 \\
\hline Cana de açúcar & 3 \\
\hline Feijão & 9 \\
\hline Hortaliça & 7 \\
\hline Laranja & 4 \\
\hline Milho & 3 \\
\hline Outras culturas & 5 \\
\hline Soja & 5 \\
\hline
\end{tabular}

Com base nos parâmetros apresentados no tópico 8.7 chegou-se às seguintes pontuações parciais, como exposto na tabela 68:

Tabela 68 - Pontuação Parcial dos parâmetros relacionados ao uso e ocupação.

\begin{tabular}{|c|c|}
\hline Limite & Grau de influência \\
\hline $9-22$ & Baixo \\
\hline $23-46$ & Médio \\
\hline $47-90$ & Alto \\
\hline
\end{tabular}

Com a soma de todas as variáveis e pontuação total por amostra (afloramento) atribui-se os "scores", podendo ser classificado como sendo baixo, médio e alto, mas devido às possíveis combinações, que chegam a valores bem diferentes, considerando-se como curso d'água classe I, todo aquele que obtenha pontuação limitada entre 51 e 83 pontos (somatório de pontuação inferior a 5).

Para os que forem denominados como classe III, são aqueles cujos valores calculados estiveram limitados entre a faixa de peso 5 a 7 , totalizando um limite de pontos entre 141 a 261. Para os de classe V, são aqueles com pontuação entre 235 a 261 pontos, obtidos através do somatório entre as variáveis com peso entre 8 a 9 .

Intermediariamente a estas classes, foram definidas as subclasses, cujos valores estivessem entre os limites atribuídos pelas classes (parcialmente alterado = 84-141 pontos e muito alterado = 194-234 pontos (ver tabela 69). 
Percebe-se através da tabela 69, a existência de uma série de limites entre as classes, onde estes valores são baseados no somatório do menor e do maior valor atribuído as grupos chaves (natural, levemente alterado, muito alterado e degradado), embora para facilitar a classificação dos corpos d’água, estes valores foram readaptados.

Vale salientar que na ausência de peso inferior a 5 para compor os limites citados, estes valores foram acrescidos e somados com os das respectivas faixas limites. As faixas intermediária foram definidas pelos limites das faixas chaves.

No caso de ocorrer mais de uma opção durante o processo de avaliação, como em problemas geotécnicos, soma-se o maior valor apresentado, embora, qualitativamente, deve-se citar textualmente a variável não inclusa na pontuação.

Vale lembrar que o processo de classificação aqui proposto, deve ser feito por segmentos dentro da área de um determinado rio, contemplando diferentes áreas em seu interior, como também, no entorno dele, sendo limitado, ao espaço que corresponde à faixa marginal ou no máximo, na região que corresponde ao leito excepcional que um determinado rio atinge em cheias ocorridas em eventos extremos, quanto à área que o rio ocupa.

A partir da totalização da pontuação por avaliação, tem-se a seguinte distribuição qualitativa, relacionada às condições geoambientais da drenagem e de seu entorno (tabela 69).

Tabela 69 - Pontuação adotada para a classificação paramétrica do curso d'água.

\begin{tabular}{|c|c|c|}
\hline ¿total Limite & Classificação & Classe \\
\hline$<83$ & Natural & I \\
\hline $84-141$ & Levemente alterado & II \\
\hline $142-193$ & Alterado & III \\
\hline $194-234$ & Muito altado & IV \\
\hline$>235$ & Degradado & V \\
\hline
\end{tabular}

O critério adotado na escolha destes pontos teve como base o espaçamento necessário que permitesse a representação cartográfica das informações obtidas em campo e em laboratório, através da adoção de duas escalas distintas: 1/5.000 (espaçamento usado na largura do canal, na forma de seção, incluindo o leito, as 
margens e o espaço correspondente à faixa marginal) e 1/50.000 (longitudinal espaçado em certa de $500 \mathrm{~m}$ um do outro), totalizando em 35 formulários (5 formulários por seção), pela técnica de Detalhamento Progressivo (ver tópico 6.11).

O modelo de formulário adotado para a avaliação da qualidade do meio físico pode ser visto no Apêndice 1.Este sistema foi testado no Córrego das Cruzes, município de Santo Antônio do Aracaguá/SP, cuja variação da pontuação por avaliação do sistema proposto pode ser observada no gráfico 3.

Através da aplicação do Sistema de Avaliação Geoambiental, cujos dados foram coletados em campo e parte deles foram tratados em laboratório, observou-se que os pontos de controle da área apresentaram pontuação variando entre 192 no ponto 13 e máximo de 242 no ponto 5 , como visto na tabela 70 , incluindo a distribuição gráfica desta aplicação, pode ser observada no gráfico . 
Tabela 70 - Proposta de classificação final baseada na pontuação obtida após sua aplicação por segmento.

\begin{tabular}{|c|c|c|}
\hline Pontuação & Classificação & Caracterização \\
\hline $51-83$ & Natural & $\begin{array}{l}\text { Quando apresentava pelo menos } 50 \mathrm{~m} \text { de vegetação } \\
\text { natural em torno do olho d'água em nascentes pontuais ou a } \\
\text { partir do olho d'água principal em nascentes difusas; } \\
\text { vegetação ripária natural no trecho de } 300 \mathrm{~m} \text { a partir do olho } \\
\text { d'água em ambas as margens; influência antrópica mínima ou } \\
\text { ausente. }\end{array}$ \\
\hline $84-141$ & $\begin{array}{c}\text { Levemente } \\
\text { Alterado }\end{array}$ & $\begin{array}{l}\text { Quando não apresenta } 50 \mathrm{~m} \text { de vegetação natural em seu } \\
\text { entorno e vegetação ripária natural no trecho de } 300 \mathrm{~m} \text {, mas } \\
\text { apresentam bom estado de conservação, apesar de serem } \\
\text { ocupadas por poucas pastagem/agricultura ou pequenas } \\
\text { influências antrópicas. }\end{array}$ \\
\hline $142-193$ & Alteração & $\begin{array}{l}\text { Quando não apresenta } 50 \text { m de vegetação natural em seu } \\
\text { entorno e vegetação ripária natural no trecho de } 300 \mathrm{~m} \text {, mas } \\
\text { apresentam bom estado de conservação, apesar de serem } \\
\text { ocupadas por pastagem/agricultura ou influências antrópicas } \\
\text { mais acentuadas. }\end{array}$ \\
\hline $194-234$ & Muito Alterado & $\begin{array}{l}\text { Quando não apresenta } 50 \mathrm{~m} \text { de vegetação natural em seu } \\
\text { entorno e vegetação ripária natural no trecho de } 300 \mathrm{~m} \text {, mas } \\
\text { apresenta-se em estado de conservação ruim, apesar de ser } \\
\text { ocupada por pastagem/agricultura ou grande influência } \\
\text { antrópica. }\end{array}$ \\
\hline $235-261$ & Degradado & $\begin{array}{l}\text { Quando encontra-se com alto grau de perturbação no } \\
\text { entorno de } 50 \text { m do olho d'água e vegetação ripária no trecho } \\
\text { de } 300 \mathrm{~m} \text {; solo compactado; presença intensa de gado; } \\
\text { presença de erosões e voçorocas. Influência intensa de } \\
\text { atividade antrópica. }\end{array}$ \\
\hline
\end{tabular}




\section{APRESENTAÇÃO E ANÁLISE DOS RESULTADOS}

Com base nas informações apresentadas no capítulo 6 e nos dados obtidos por meio do sistema de avaliação em proposição, no capítulo 7 , chegou-se a resultados que será discutidos doravante.

\subsection{Comparação entre técnicas distintas}

A partir da investigação sobre a constituição do maciço terroso que compõe a área de estudo, constatou-se que o local é formado, predominantemente, por materiais geológicos na fração areia, com variação de muito fina a grossa, com presença de argila, silte (desembocadura) e cascalhos (interior de afloramentos rochosos).

A predominância da fração arenosa torna o solo mais susceptível à erosão, especialmente por ser um solo pobre em teor de matéria orgânica, fato este observado não só no interior dos solos quanto nos sedimentos carreados e transportados rio abaixo, conforme pode ser observado no gráfico 3 . 


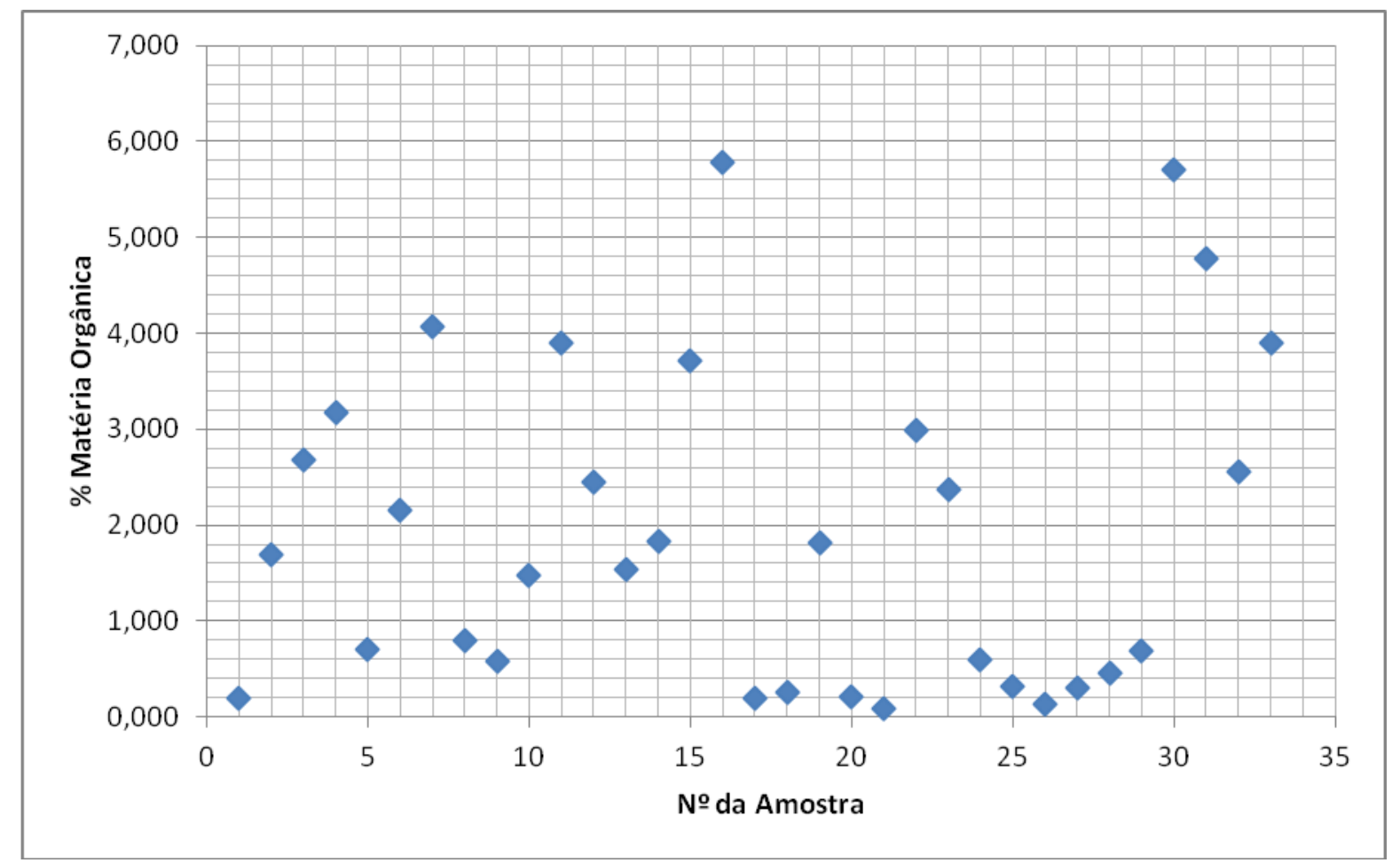

Gráfico 3 - Variação percentual do teor de matéria orgânica dos materiais geológicos da área de estudo.

O gráfico 3 apresenta a distribuição percentual das amostras dos solos, que foram quantificadas, e o teor de matéria orgânica, onde percebe-se que o maior percentual foi inferior a $6 \%$ do conteúdo, demonstrando o quão pobre é o solo local e tão susceptível ao ataque das águas pluviais, especialmente nas porções do terreno mais inclinadas, constituídas por trilha usada pelo gado, como se observa na figura 39.
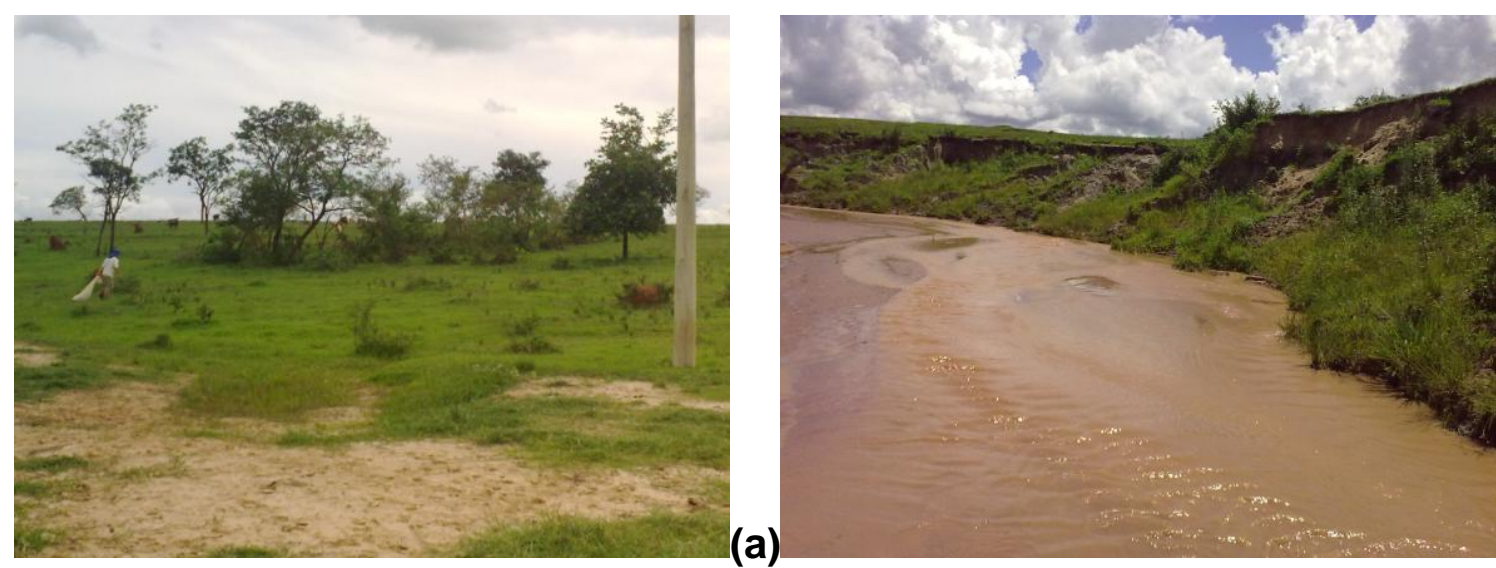

(b)

Figura 38 - Uma das áreas usadas pelo gado para acesso ao Córrego das Cruzes (a) e degradação das margens pelo pisoteio do gado (b). 
A figura 39 exemplifica um dos locais usados pelo gado para ter acesso à água, na qual a parte (a) expõe ao fundo o gado e a parte (b) exibe a degradação da vertente, na forma de depósito de talus gerada pelo pisoteio do gado e remoção dos sedimentos do "solo" pela tração das patas encosta abaixo.

Os problemas geotécnicos da área de estudo, incluindo as trilhas criadas pelos bois, podem ser vistos no mapa de feições erosivas.

Quanto à dinâmica do gado ao longo da área de estudo, percebeu-se que os mesmos foram facilitadores da degradação do solo, ao ponto de compactar porções do terreno, que já possui uma elevada facilidade de ser erodido.

Nesta questão, o pisoteio do gado, em pontos distintos ao longo da drenagem fez com que o solo fosse compactado, removendo as gramínas, bem como impermeabilizando o solo, como se observa pela baixa permeabilidade da área de estudo (ver tabela 71).

Conforme citado nos procedimentos teórico-metodológicos quanto à elaboração do ensaio de infiltração, segundo os procedimentos práticos apresentados por Guerra (2002), chegou-se ao seguintes valores (tabela 71):

Tabela 71 - Dados provenientes do ensaio de infiltração.

\begin{tabular}{|c|c|c|c|c|c|c|c|c|c|}
\hline \multicolumn{10}{|c|}{ Furos } \\
\hline & F1 & F2 & F3 & F4 & F5 & F6 & F7 & F8 & F9 \\
\hline 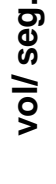 & $\begin{array}{l}\frac{1}{0} \\
\frac{0}{x} \\
0 \\
-\end{array}$ & 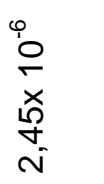 & 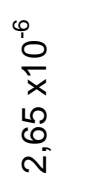 & $\begin{array}{ll}\stackrel{0}{+} & 0 \\
\sim & 0 \\
\sim & \end{array}$ & 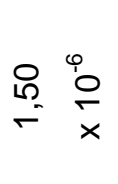 & $\begin{array}{l}\hat{i} \\
\stackrel{x}{x} \\
\text { m }\end{array}$ & 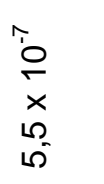 & $\begin{array}{l}\hat{i} \\
\dot{x} \\
\dot{x}\end{array}$ & 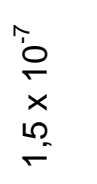 \\
\hline
\end{tabular}

Legenda: $\mathrm{v}=$ volume do tubo; $\mathrm{f}=$ furo; $\Delta \mathrm{T}=$ Tempo (minuto); $\Delta \mathrm{h}=$ altura $(\mathrm{mm})$; $\Delta$ vol. = volume $\left(\mathrm{mm}^{3}\right) ; \Delta \mathrm{T} / \mathrm{s}=$ tempo/segundo; Per. = permeabilidade .

Dados os ensaios de permeabilidade realizados na área de estudo, percebeuse que as maiores permeabilidades ocorreram nos furos de números 1, 2, 3, 4 e 5, mesmo assim, os mesmos foram considerados como sendo de muito baixa permeabilidade, ao passo que os demais furos (6, 7, 8 e 9) foram classificados como sendo praticamente impermeáveis, com base nos parâmetros estabelecidos por Stancati; Nogueira; Monjevilar, 1981 apud Lorandi et al., 2001. 
Apesar dos valores apresentados serem significativamente baixos, constatouse que a capacidade de retenção de água no solo foi mais facilitada nos locais com sedimentos friáveis (proximidade de encostas e ilhas arenosas no canal), ao passo que nas porções superiores do relevo, o solo obteve baixa capacidade de reter água, como visto nos furos F6. F7, F8 e F9.

Vale lembrar que a variação da permeabilidade ocorre em função do índice de vazios, composição mineralógica, caracterização granulométrica, estrutura dos agregados que compõem os solos, o tipo de fluido existente em seu interior, feições macro-estruturais (como por exemplo: fraturas, diáclases, estratificações, dentre outras), incluindo ainda, a temperatura do meio (PINTO, 2006; SOARES; PINHEIRO; TAVARES, 2006).

Com relação aos materiais que compõem o substrato da área de estudo, através das propriedades morfológicas dos solos, feitas em pontos distintos, ao longo de ambas as margens, contatou-se que a estrutura dos solos é composta, predominantemente, por estrutura colunar embora ocorra em tamanho variado, seguido da ausência de estrutura.

Tal fato pode ter sido causado pelo uso e ocupação do solo, pois o pisoteio excessivo pode modificar a estrutura do solo.

Como relação a porosidade, a mesma foi definida como sendo pequena (propriedades dos solos), apesar de apresentar-se com tamanhos variandos (de muito pequena a pequena).

Com relação à plasticidade destas estruturas, ao serem umedecidas, observouse que mesmo as mesmas não apresentaram plasticidade, em função da ausência, ou do baixíssimo, teor de argilo-minerais, embora pequenas proporções possam ser sentidas ao realizar o ensaio aqui comentado, como mostrado na tabela 24.

Com relação às cores dos materiais geológicos granulados, percebeu-se que as mesmas variam de brunos (amarelados, acinzentados, avermelhados $\mathrm{e}$ gradações de cor ao serem umedecidas), cinza (brunado-claro e cinza claro).

Estas cores estão associados ao teor de óxido de ferro (férrico ou ferroso), onde são encontrados em locais que paresentaram paleoclima mais quente. 


\subsection{Análise dos dados do Sistema de Avaliação Geoambiental}

Através da aplicação dos 24 formulários, apresentados anteriormente, foram obtidos os seguintes resultados (ver gráfico 4 e Apêndice 5), quanto a pontuação geral.

Com base nos dados referentes à pontuação deste sistema de avaliação , percebeu-se que os mesmos variaram de 206 pontos, no ponto 12 e, no máximo, de 258 pontos no ponto 6 . Por outro lado, a média total por formulário entre sí, desde 6,24 (formulário 12) a 7,89 (formulário 19).

Quanto ao conjunto de parâmetros que compõem o sistema de avaliação, devido ao fato da área de estudo estar dentro da mesma faixa climática, a pontuação foi a mesma para todos os locais apresentados.

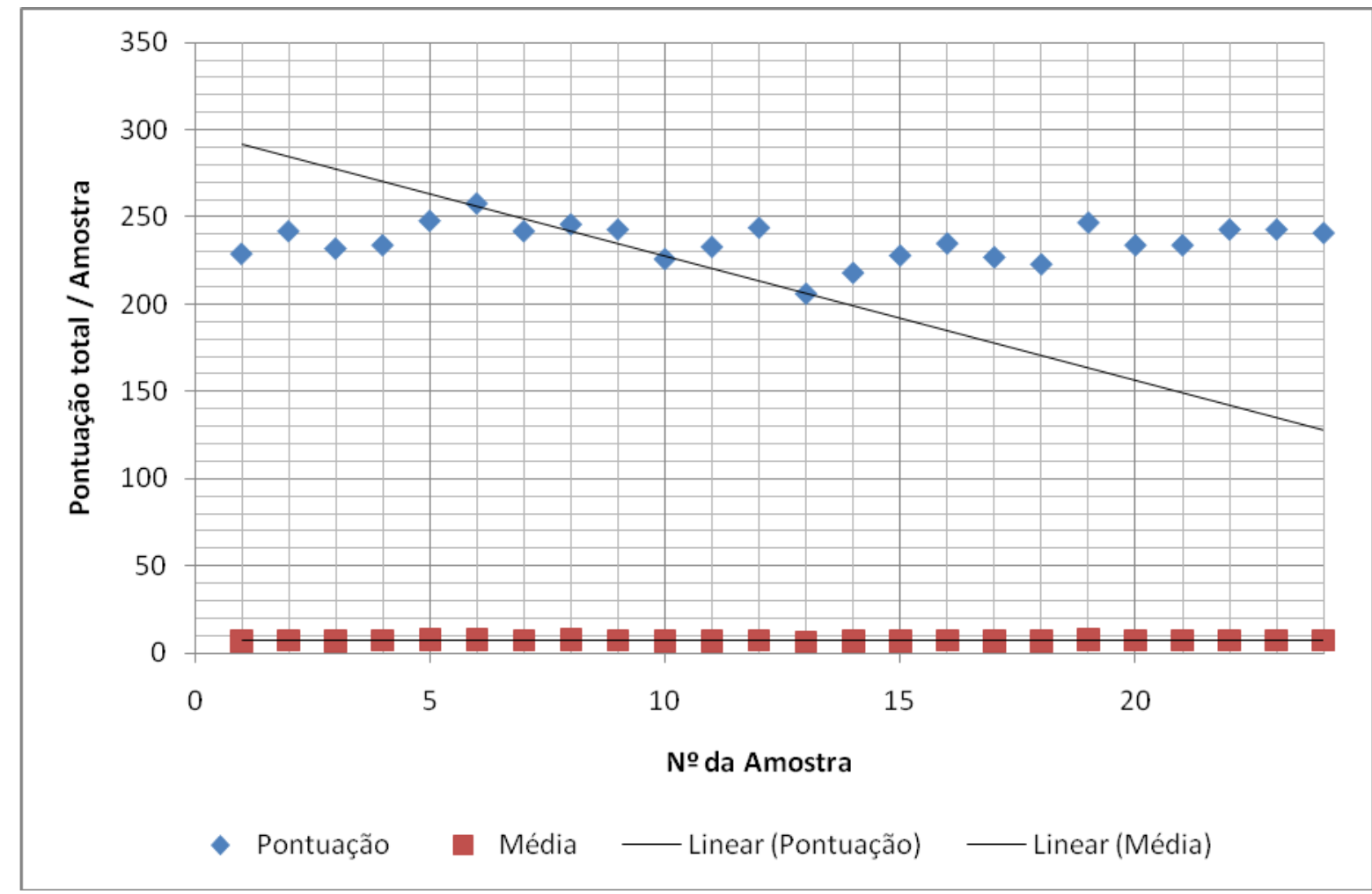

Gráfico 4 - Distribuição da pontuação total do Sistema de Avaliação Geoambiental.

Baseado nos critérios adotados e comentados, a área de estudo está inserida em um local com alta potencialidade de participar do processo de degradação, devido ao regime climático (a pontuação foi de 23 pontos por formulário). 
Os dados referentes aos parâmetros geológicos mostraram que o menor resultado ocorreu no ponto de controle de o 12, cujo valor foi de 7 pontos, contrastando com 18 pontos ocorridos nos pontos de controle no de 8-11 e 15 a 24 .

O ponto de № 12 estava localizado no interior de um afloramento rochoso, contendo como característica, litologia do tipo areníto, compostos por clastos mal selecionados, rico em quartzo e mica, provavalmente de origem fluvial, cujas arestas encontram-se semi-arredondadas.

A distribuição espacial deste afloramento é vista em uma pequena porção da área de estudo, onde foi possível observá-lo em parte das margens do canal.

Os locais com pontuação mais elevada estão relacionados aos depósitos sedimentares inconsolidados, como nos pontos 17 e 18, como também nos solos transportados dos pontos 10 e 13, e depósitos aluviais foram encontrados nos pontos 16 a 24 .

Com relação aos parâmetros geomorfológicos, os menores resultados ocorreram nos pontos de controle de no 3,13 e 24 ( 20 pontos), ao passo que nos pontos 12 e 17 a pontuação verificada foi de 31 pontos, conforme mostra a figura 37 .

Como observado e computado através dos formulários aplicados, a área é formada, principalmente por depósitos sedimentares, no caso inconsolidados, pois o material é extremamente friável e susceptível ao carreamento por ação hídrica. Apesar de que um afloramento rochoso de arenito ter sido observado nos pontos de observação 13 e 18.

Quanto aos materiais inconsolidados, os mesmo são compostos por depósitos sedimentares tanto inconsolidados quanto pedogenisados, como no caso dos Neossolo Quartzarênico e do Neossolo Quartzarênico Hidromórfico (nas encostas).

Este hidromorfismo está associado à presença de nascentes, que confere umidade aos solos formados pela ação gravitacional nas encostas da drenagem (depósito de talus), incluindo ainda as margens que se encontram parcialmente inundadas ao longo do ano. 


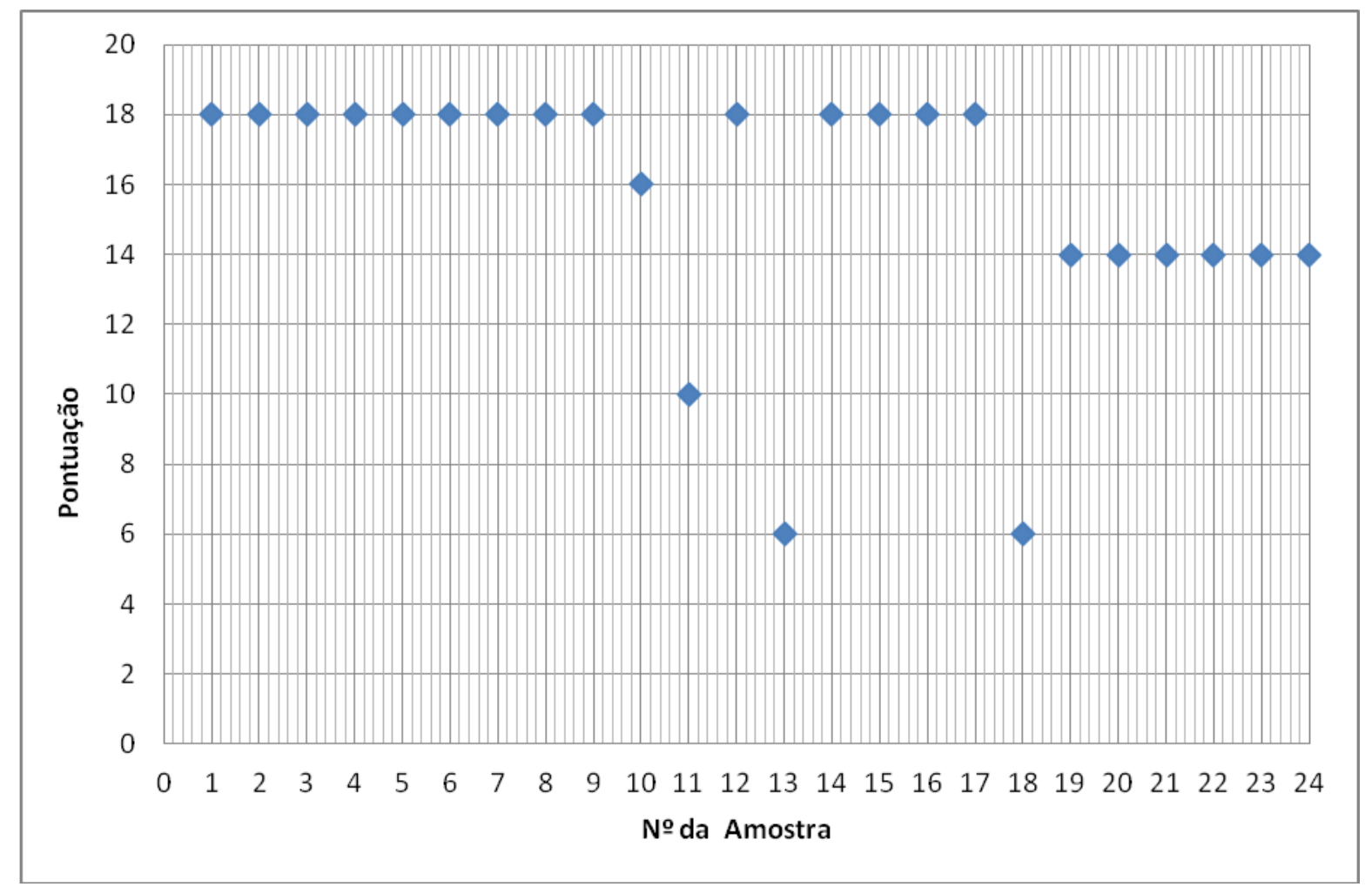

Gráfico 5 - Variação das propriedades Geomorfológicas da área de estudo com base no Sistema de Avaliação Geoambiental.

A partir da medição da vazão em três pontos distintos da área de estudo e o resultados destas leituras mostraram que a vazão é baixa, se comparada com as faixas de variação de vazão, onde adotou-se a faixa limite para todos os formulários aplicados, que foram acrescentados à pontuação total.

Neste sentido o maior resultado foi observado nos pontos 1, 6, 8, 13, 14, $19 \mathrm{e}$ 22 (27 pontos) e valor mínimo no ponto de controle 23 (17 pontos), como mostra o gráfico 6.

Os valores padrões nestes formulários, além de sua vazão, foi o teor de sólidos em suspensão, que foi baixo para todos os pontos de controle. 


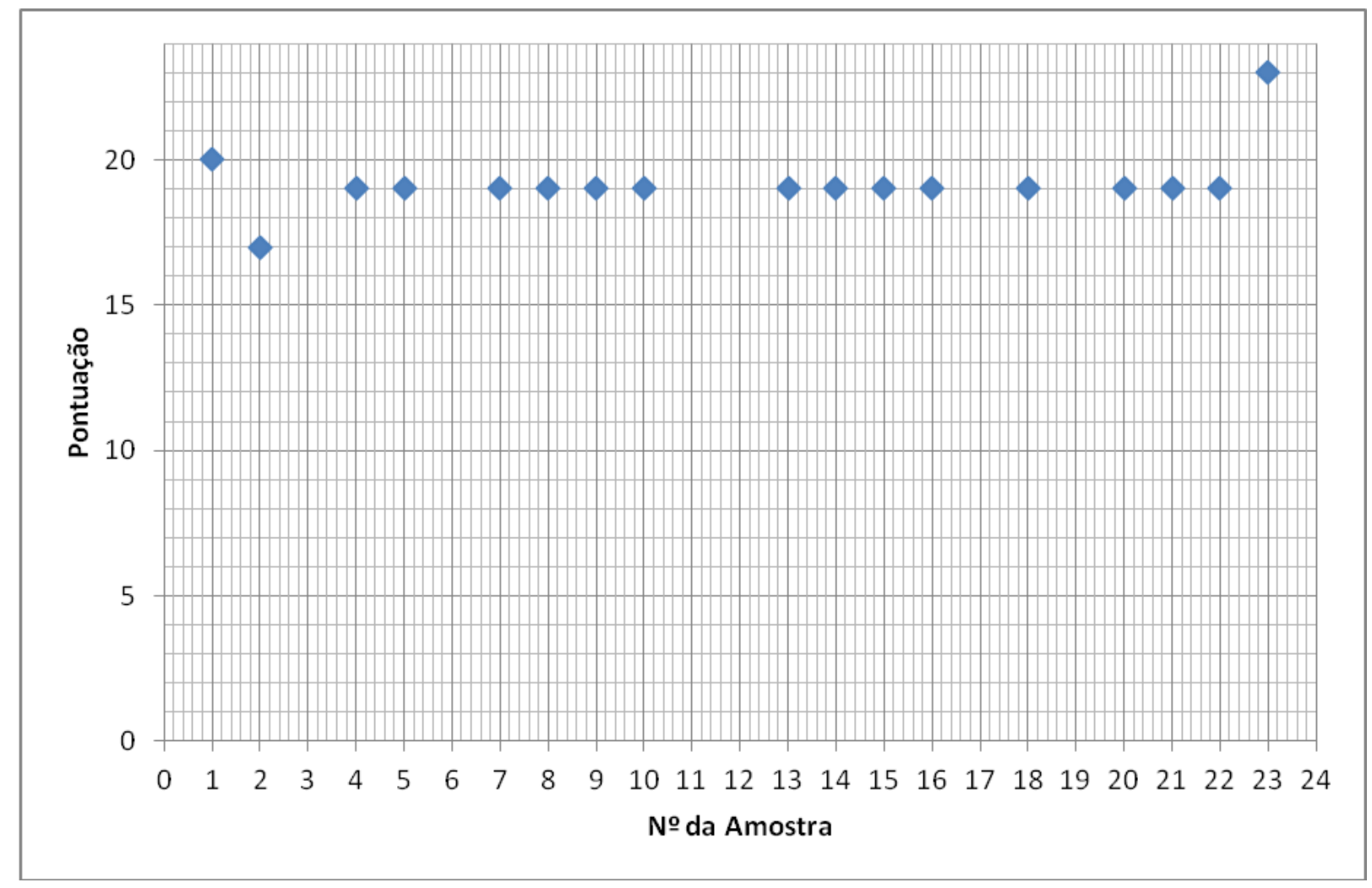

Gráfico 6 - Variação das propriedades hidráulicas da área de estudo com base no Sistema de Avaliação Geoambiental.

Vale salientar que nos segmentos analisados, apenas o ponto 23 foi definido como sendo de regime intermitente, pois este segmento do canal sofre com as variações do regime climático (estiagem), provavelmente com influência da topografia, já que se encontra em uma porção levemente elevada em relação à altura da lâmina dágua, que é baixa nesta porção, como se observa na figura do segmento, no período de estiagem (desembocadura esquerda), como mostra a figura 41.

A figura 39 (abaixo) mostra o local investigado sob regime climático distinto, cuja desembocadura esquerda encontrou-se intermitente em função do regime pluvial e morfologia do terreno. 

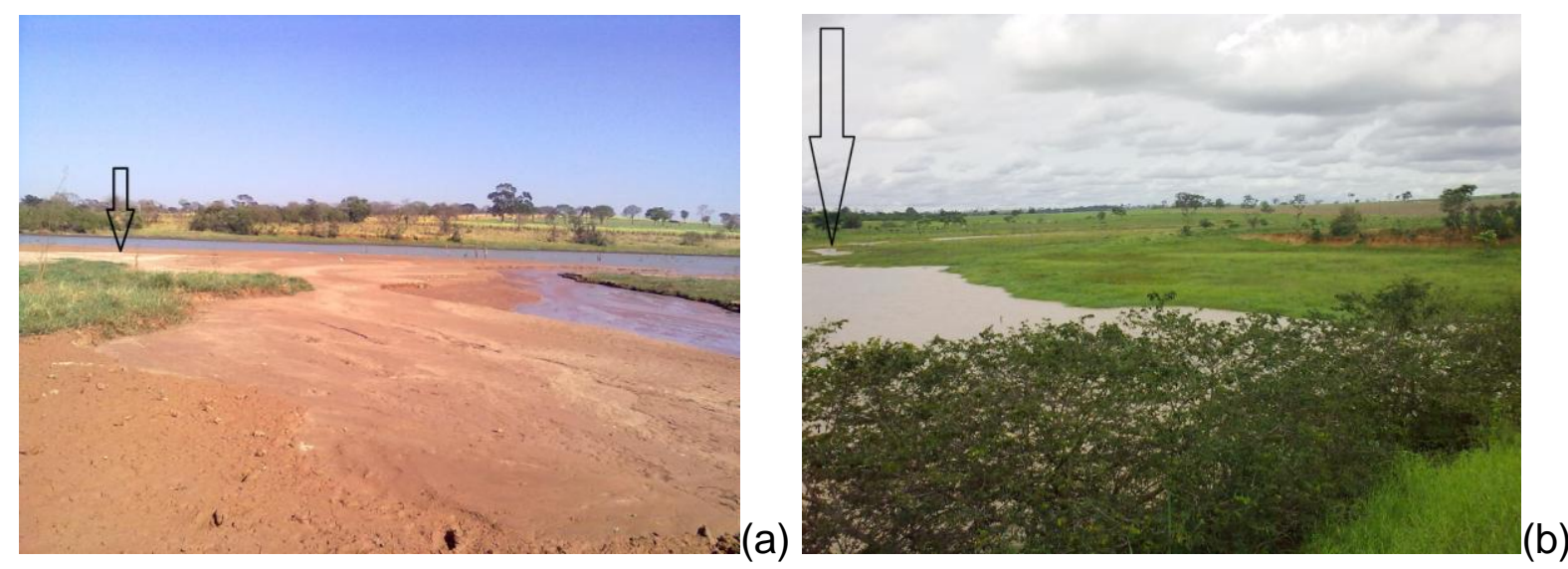

Figura 39 - Vista da desembocadura esquerda sob período de estiagem (a) e em escoamento causado durante a quadra chuvosa (b).

Dada a distribuição espacial dos parâmetros hidráulicos, observa-se que o menor valor observado foi percebido no ponto de controle de ํo 2 .

Com relação ao aporte de sedimentos transportados pelo fluxo de água rio abaixo, os valores observados foram inferiores a $5 \%$, que os classificaria como sendo muito baixos, mesmo quando avaliado o teor de sedimentos tanto no verão como no inverno, embora os sedimentos captados pelos filtros sejam de materiais finos (areia muito final, silte, argila e resíduos orgânicos vegetais).

Os parâmetros, pedológico e geotécnico, apresentaram valores elevados, como mostra o gráfico 7, onde o menor valor ocorreu no ponto de controle № 24 (33 pontos, média influência), ao passo que o maior foi de 43 pontos (pontos de controle ํo 9, 10 e 19, se comparados com a faixa padrão estabelecida.

Esta variação pode ser vista no gráfico 7 , onde a curva de tendência segmenta as informações em dois grupos distintos, onde o menor valor ocorreu no ponto 24 . 


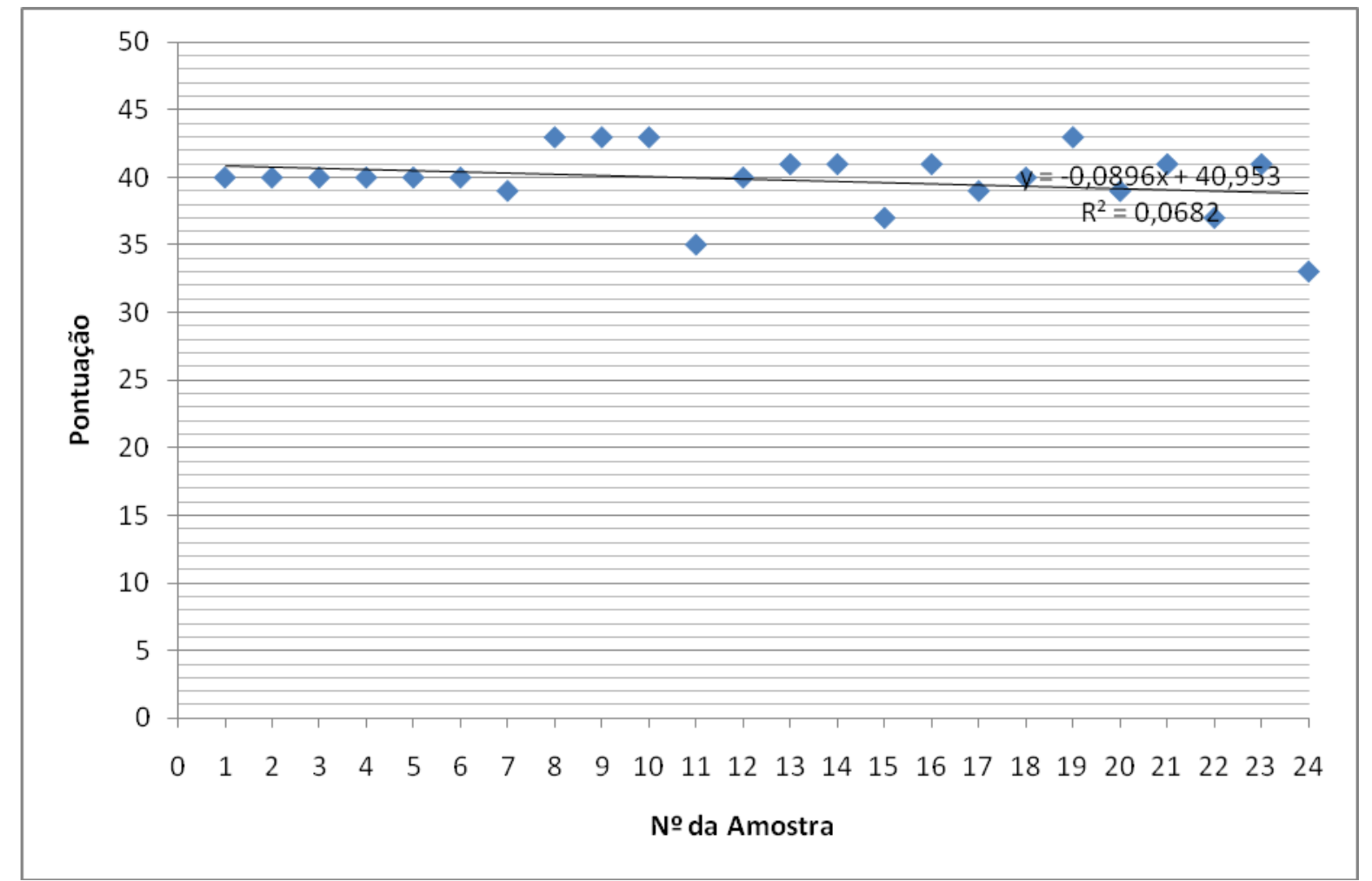

Gráfico 7- Variação das propriedades geotécnicas da área de estudo com base no Sistema de Avaliação Geoambiental.

A figura 40 corresponde a uma porção do córrego em estudo que possui quatro manilhas (na porção acima deste local passa uma estrada de terra, possuindo duas manilhas em cada segmento desta via), pode ser visto que uma delas está assoreada, cujos materiais são areno-siltosos, mesmo com nível d'água raso e com ausência de vegetação ribeirinha ao longo do canal.

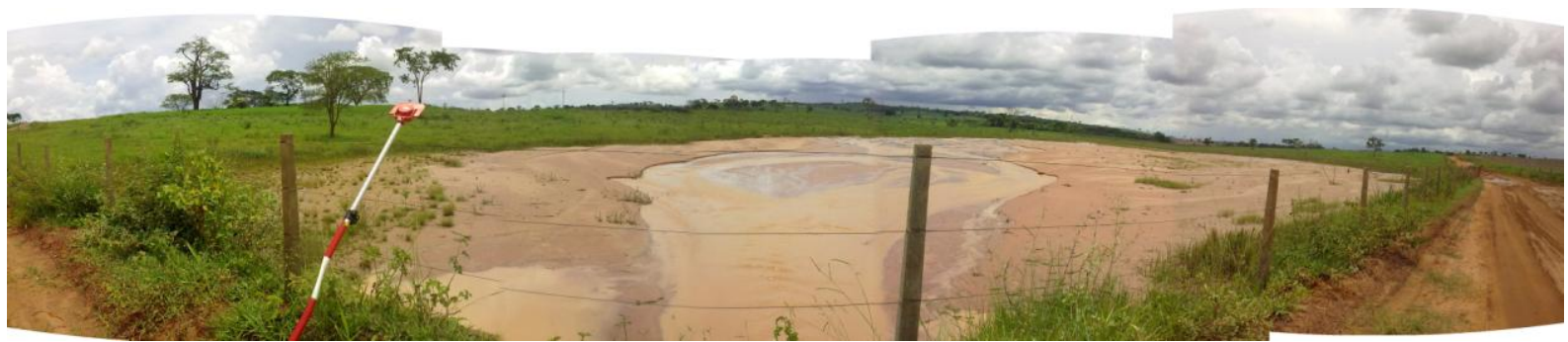

Figura 40 - Vista da área localizada próxima aos pontos de controle 19 e 20 (Autor: E. J. Albuquerque Sobrinho).

De modo geral, a influência elevada deste conjunto de dados que compõe o comentado parâmetro prevaleceu (limite entre 38 a 45 pontos), tendo em vista as características geotécnicas investigadas, como elevada concentração da fração 
areia, baixo teor de matéria orgânica, solos impermeáveis, soma-se a isso os problemas geotécnicos que são condicionados pelos constituintes do meio físico.

Sobre as variáveis que compõem os parâmetros ecológicos, as mesmas sofreram influência das condições do meio físico e das atividades exercidas pelo homem (sociedade), e estas mesmas atividades causam danos tanto ao homem quanto ao ambiente.

Através da análise das variáveis que compõem o aspecto ecológico, percebeuse os valores totais variaram de 15 pontos (ponto 8) e máximo de 45 (vários pontos de amostragem apresentaram este valor, como nos pontos 1, 2, 3, 4, 5, 6, 9, 17,18, 19, 20, 21, 23 e 24 (ver gráfico 8).

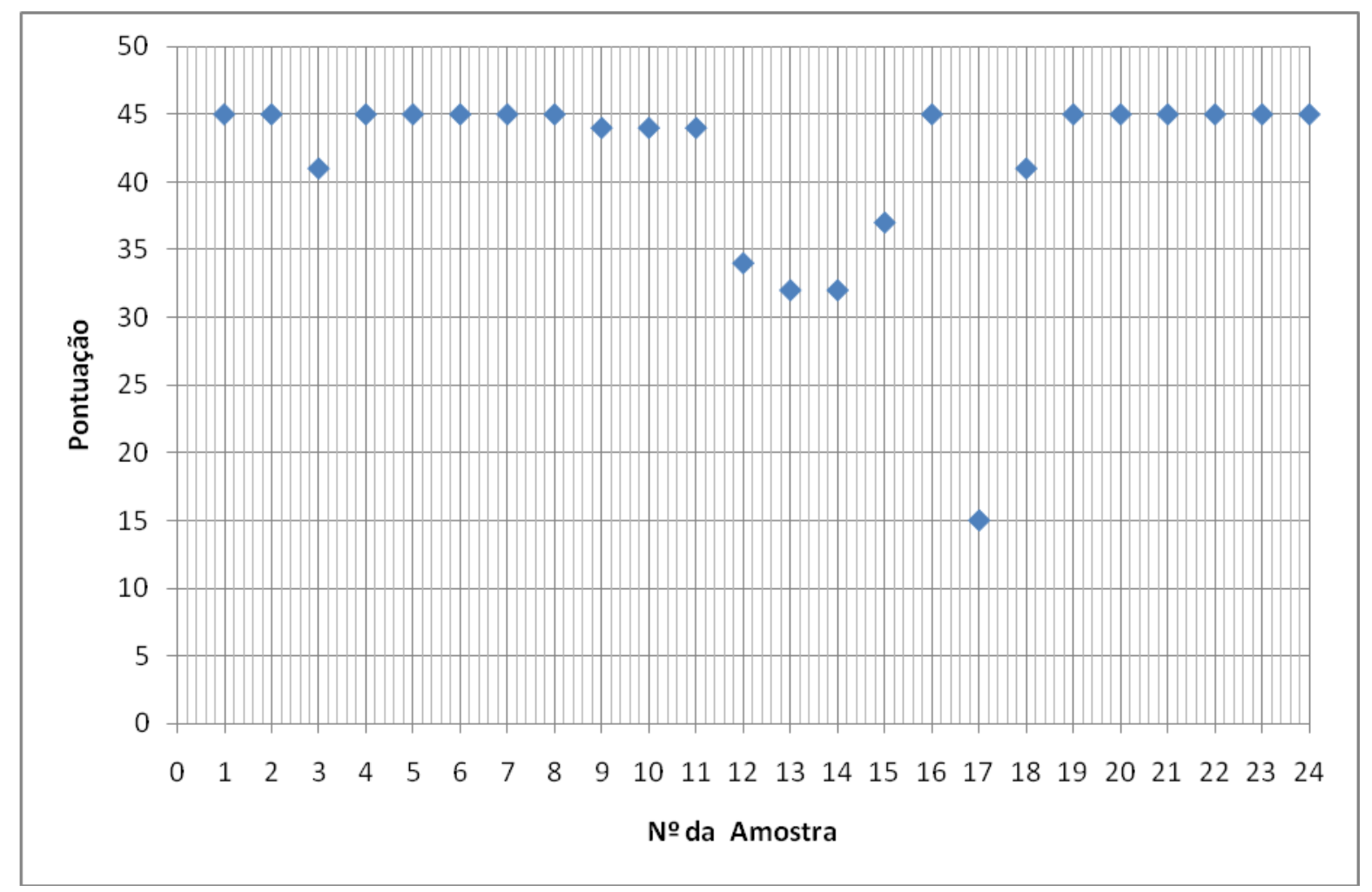

Gráfico 8 - Variação das propriedades ecológicas da área de estudo com base no Sistema de Avaliação Geoambiental.

Conforme os limites adotados em uma classificação preliminar, exibido na tabela 57, percebeu-se que o peso deste parâmetro foi marcante no processo de degradação, posto que a grande maioria dos dados que compõem este parâmetro indicou uma alta influência dos constituintes ecológicos, já que apenas um espaço amostral obteve resultado baixo, embora no extremo limite entre baixa a média 
influência, sendo os demais com valores acima de 28 pontos, como mostra o gráfico 8.

A área de estudo é utilizada no presente momento para plantio de cana de açúcar, embora em meados do ano de 2011, o proprietário das terras localizadas ao longo do córrego em questão, modificou o uso da terra, de pastagem para cana de açúcar. E As práticas adotadas e a interação social com o ambiente degradou a área de estudo, como exposto e abordado.

Com relação aos dados oriundos das propriedades relacionadas ao uso da terra, a menor pontuação contabilizada foi de 41 pontos na estação 22, ao passo que o maior valor foi de 77 pontos no ponto de avaliação 17.

Com base na pontuação do parâmetro citado, a média observada por estação variou de 5,8 nos pontos 21, 22 e 24 e máxima de 7,7 no ponto de controle 17 .

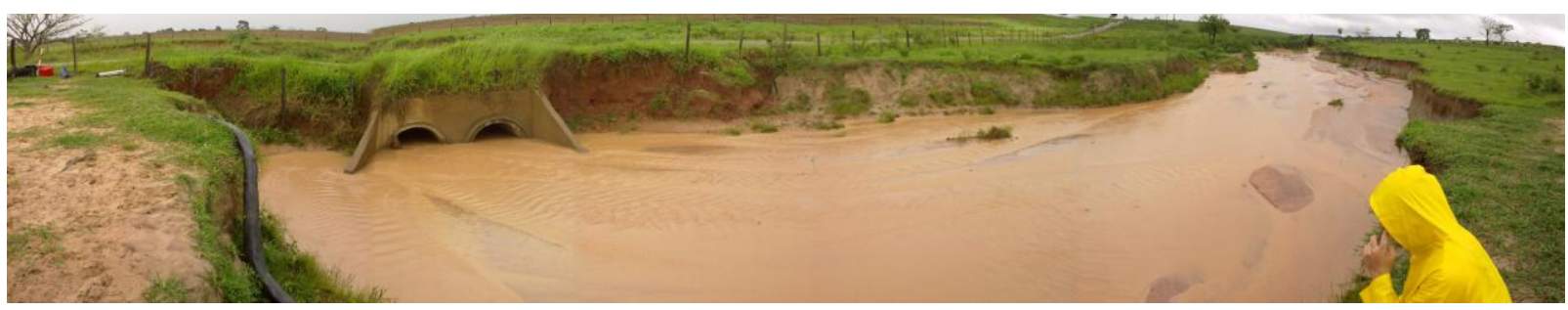

Figura 41 - Vista da manilha localizada entre os pontos 16 e 17 (Autor: E. J. Albuquerque Sobrinho).

A figura 41 mostra um dos locais avaliados, compreendendo um segmento do córrego em meandro, com presença de duas manilhas, onde as mesmas encontramse parcialmente assoreadas/ entupidas, com início de erosão no contato entre o terreno e a parte em concreto.

Neste contato, a água em escoamento gera um vórtice no contato entre os diferentes materiais e ausência de espaço para escoamento, sendo que na área de estudo existe dois pontos contendo oito manilhas, posicionados no contato da drenagem com duas estradas de terras existentes (ver figuras 42 e 43).

Vale salientar que na área de estudo existem dois pontos contendo quatro manilhas por segmento, posicionados em locais com presença de estrada de terra.

A partir dessa área, observa-se que as condições médias estão, pelo menos, como sendo acima do valor definido como intermediário, tendendo a valores que classificaria os pontos como sendo de média a alta influência. 


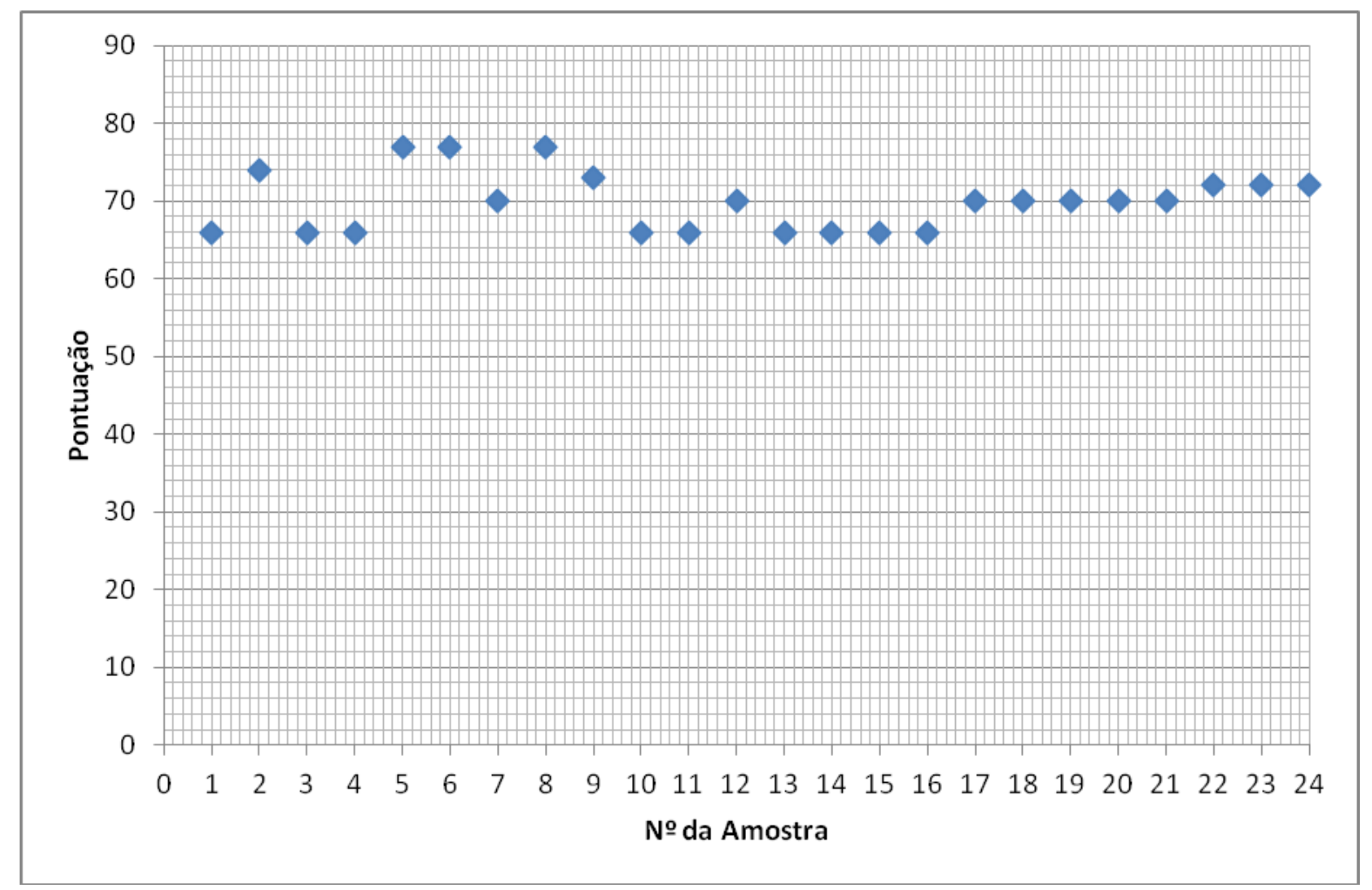

Gráfico 9 - Variação das propriedades relacionadas ao uso e ocupação ao longo da área de estudo com base no Sistema de Avaliação Geoambiental.

Com a análise dos dados que compõem este parâmetro, cujos dados encontram-se no apêndice 5 , tabela 108 , observou-se que a pontuação geral variou de 66 (pontos de controle 9, 10, 11, 12, 14,15, 21, 22 e 24) e máximo de 77 (pontos de controle 17, 19 e 20).

Através da faixa limite proposta (pelo sistema de avaliação em foco), que se encontra na tabela 68 , estas informações poderiam ser classificadas como sendo de alta influência (faixa limite variando de 47 a 90 pontos) em todos os pontos levantados.

A ausência de infra-estrutura (tabela 96), da localização do cultivo agrícola (tabela 104) e do tipo de cultura (tabela 104) apresentou a menor pontuação (1 ponto por variável), apesar da existência de variações (entre 3 e 5 pontos).

Vale destacar que os pontos de amostragem entre 19 a 24 apresentaram o menor valro em se tratando de infra-estrutura no controle de erosão (tabela 102). 
Ao comparar a pontuação total de todos os formulários, constatou-se que a média foi de 235,67, sendo valor (total) mínimo de 206 pontos (estação 13) e, máximo de 258 pontos (estação 6).

Separadamente, o menor ponto medido poderia ser denominado como sendo muito alterado e os com pontuação superior a 350 , como sendo degradado (pontos de controle de ํㅜ 1, 2, 3, 6, 9, 16, 17,18, 19, 20 e 23).

Sendo assim, o ribeirão em questão poderia ser classificado, baseado na pontuação média, como sendo um corpo lótico degradado, de classe $\mathrm{V}$.

Isto significa que o ribeirão em estudo encontra-se com alto grau de perturbação no entorno de $50 \mathrm{~m}$ da nascente, e vegetação ripária no trecho de 300 $\mathrm{m}$, contendo solos compactados, presença intensa de gado (até meados do ano de 2011), apresenta, também, feições erosivas (lineares, ravinas e voçorocas), ampliadas pelo uso inadequado da área pela atividade antrópica, segundo definição proposta na tabela 70 .

Com base na distribuição espacial destes pontos, o local observado com valor máximo está posicionado sobre o ponto 6 , como se observa na figura 42.

A figura 42 mostra um dos segmentos do ribeirão onde se percebeu um conjunto de patamares causados pela ruptura de um antigo reservatório que se rompeu, causando a erosão marginal, ampliada pelo pisoteio do gado em conjunto com as condições desfavoráveis do meio físico, corroborando com os dados expostos.

Os condicionantes climáticos, geológicos, geomorfológicos, geotécnicos, ecológicos e o uso e ocupação foram predominantes no processo de degradação fluvial.

Nesta questão, os parâmetros relacionados com a hidráulica tiveram participação moderada, posto que o teor de sedimentos carreados foram relativamente baixos em função da vazão, apesar da disponibilidade de sedimentos em seu entorno.

Embora a variável climática ter tido um papel importante neste processo, observou-se que, no período de estiagem, a vazão e o teor de sedimentos totais variavam segundo a dinâmica pluvial (quadra chuvosa e de estiagem), mesmo com 
chuva, o aporte de sedimento não foi significativo, segundo os parâmetros definidos na tabela 42 (ver dados de campo localizados na tabela 25).

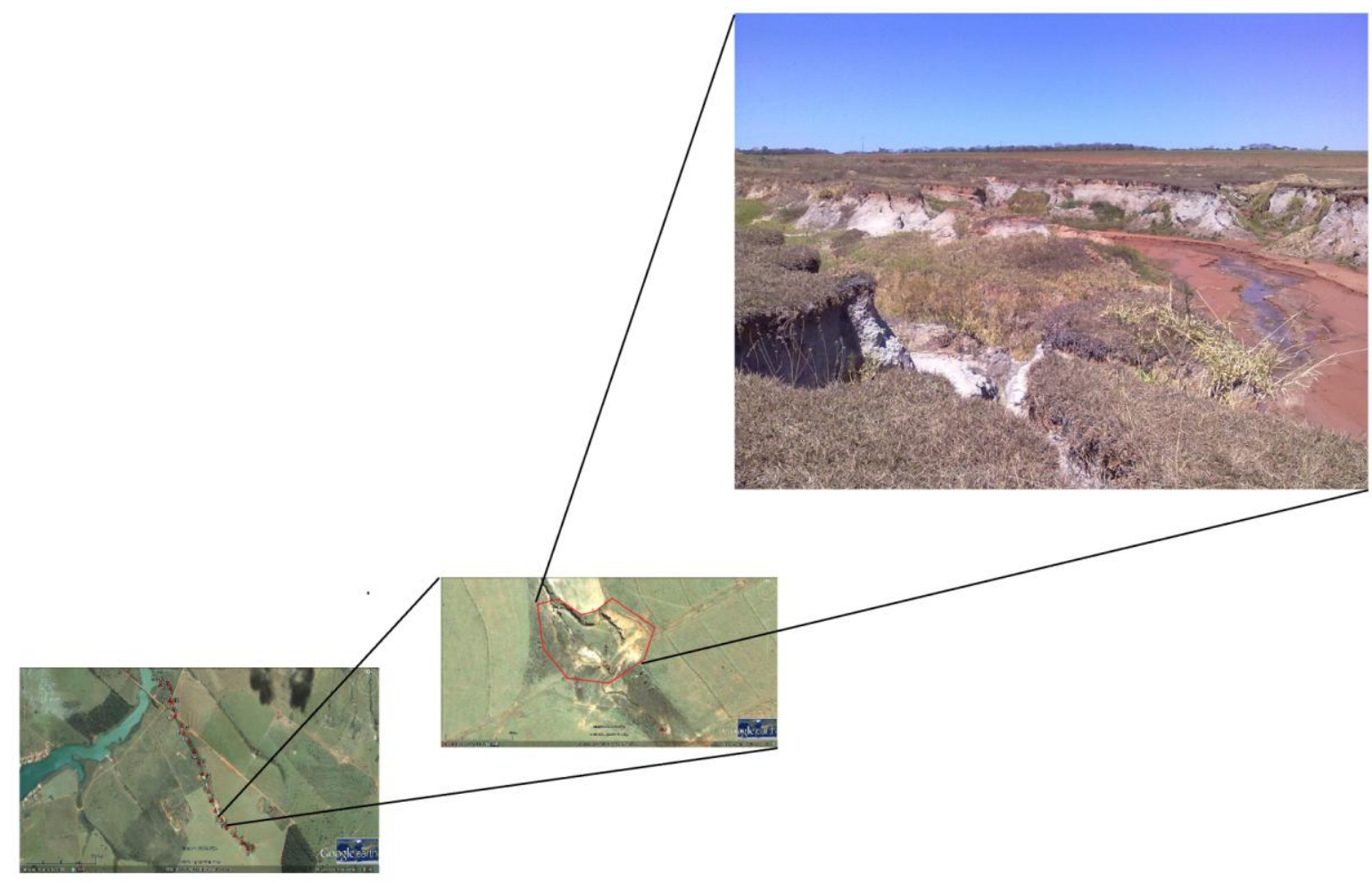

Figura 42 - Ponto de estudo com maior pontuação total - Estação 6 (Autor: Google Earth; E. J. Albuquerque Sobrinho). 


\section{CONCLUSÕES}

A abordagem geológico-geotécnica permite agrupar maiores detalhes investigativos, pois é uma das mais amplas e flexíveis metodologias aplicadas aos estudos ambientais, quando se tem os rios e demais corpos fluviais como objetos de estudo,.

No entanto, persiste uma certa dificuldade em comparar ambientes distintos pela ausência de padronização das variáveis (que podem ser) empregadas: depende das condições do ambiente, limitações sobre o conhecimento teóricometodológico do investigador, investimentos financeiros para aquisição de equipamentos, número de ensaios, custos operacionais e de logística, dentre outros.

Os resultados apresentados pelo conjunto de dados expostos separadamente foram satisfatórios, pois permitiram compreender a correlação entre as condições geoambientais e a participação destas no processo de degradação ambiental.

Estas informações mostraram que a área do estudo possui características que a torna susceptível à erosão, especialmente no que diz respeito às condições pedológicas e geotécnicas, ademais, a constituição topográfica (morfologia da drenagem), por meio da inclinação das vertentes, propicia processos erosivos como tombamento, erosão marginal e feições lineares (erosão linear, ravinas e voçorocas).

Apesar do Protocolo de Avaliação de Rápidos e demais sistemas avaliativos terem um papel importante, mesmo que limitados na avaliação ambiental, como mostrado tópicos 4.4.3 e 7.2, a avaliação feita com o referencial teóricometodológico de cunho geológico-geotécnico mostrou que a área do estudo apresentou uma elevada susceptibilidade à erosão, já que a fração areia domina os depósitos sedimentares existentes, porque pobre em matéria orgânica, que exerce um papel importante contra a erosão.

A vazão do córrego, pelo menos durante o período deste estudo, apresentou valor extremamente baixo, para que a água em escoamento exercesse um forte papel como agente causador/ ampliador da erosão marginal do Córrego das Cruzes.

Com relação às feições erosivas existentes na área de atuação do rio, percebeu-se que o uso e ocupação teve um papel forte neste processo, como 
mostrado por meio do Sistema de Avaliação Geoambiental aqui proposto, embora as técnicas adotadas não mostraram tal questão e o Protocolo de Avaliação de Rápidos (adaptado de Callixto et al., 2002; XAVIER \& TEIXEIRA, 2007) apresente, APENAS, três parâmetros relacionados aos fatores sociais (Tipo de ocupação das margens do corpo d'água, Alterações antrópicas e Alterações no canal do rio), as demais técnicas (???) podem ser interpretadas indiretamente, tornando assim passível de interpretação errônea por parte do aplicador da citada ferramenta de avaliação, soma-se a isso o fato de não ser adequada às questões ambientais mais complexas.

As diferentes abordagens relacionadas à análise ambiental (técnicas investigativas em geociências), mesmo com limitações entre si, podem ser empregadas. Isso também limita a comparação do objeto de estudo e aponte os agentes causadores do processo de degradação do ambiente, no caso em questão, um córrego localizado no interior do Estado de São Paulo que padece de problemas diversos.

Apesar da difusão destas técnicas no meio acadêmico e técnico, como foi demonstrado, as mesmas mostraram-se ineficientes para se inserir o fator social como agente causador de perturbações ambientais, já que o homem/sociedade exerce um agressivo papel como deflagrador ou facilitador da degradação ambiental nos diversos ambientes/ecossistemas.

$\mathrm{Na}$ abordagem feita pelos parâmetros morfométricos, a mesma tem um papel extremamente físico do ambiente fluvial, sendo adequado seu emprego no caso de um determinado curso d água sofrer influência dos elementos geomorfológicos e geológicos.

A cartografia temática de cunho geotécnico é uma importante ferramenta avaliativa, embora seja um pouco limitada por questões que transcendem ao arcabouço teórico geológico-geotécnico, seja ele baseado em dados de campo e/ou ensaiados em laboratório.

Neste sentido, o uso combinado desta ferramenta como sistema de avaliação em foco, teve um papel importante para corroborar os dados do meio físico com as demais variáveis expostas.

Neste sentido, o Sistema de Avaliação Geoambiental mostrou-se flexível quanto às diferentes combinações de problemas de natureza sócio-econômico- 
ambiental, apesar de ter um significativo número de variáveis que permitem "descobrir" o(s) agente(s) transformador do meio, pelo menos nas variáveis que comumente ocorrem, embora ações caóticas não tenham sido colocadas neste sistema, a fim de não dificultar a aplicação por parte de pessoas de outras áreas da ciência, no caso destas utilizarem esta técnica.

Por ser uma ferramenta de cunho quali-quantitativa, o conjunto de parâmetros aqui proposto, seguido de suas variáveis, facilita comparar rios de naturezas distintas, como se fosse uma forma de "check list".

\subsection{Sugestões de pesquisas futuras}

Apesar do resultado satisfatório obtido e apresentado pelo Sistema de Avaliação Geoambiental, monstrando-se útil para o estudo de caso da área teste (Córrego das Cruzes), diferentes estudos complementares não foram realizados devido às questões de caráter financeiro, operacionais, instrumentais e tempo de execução da tese (três anos para a elaboração e conclusão da tese).

Se for dada continuidade ao estudo na área em quastão, ou mesmo em outro rio/córrego, seria importante avaliar as seguintes demandas:

- $\quad$ Maior número de visitas de campo em momento distintos;

- $\quad$ Coleta de amostras indeformadas para realização de ensaio triaxial, tanto em solo quanto em rocha;

- $\quad$ Análise mineralógica das amostras na fração argila por meio de difração de raios-X;

- Instalação e monitoramento por meio de estação meteorológica e posto fluviométrico ao longo da drenagem ;

- $\quad$ E a instalação de armadilhas para captura de sedimentos ao longo das margens do citado córrego, seguido da análise e classificação geológico-geotécnica destes materiais;

- $\quad$ Aplicação de modelagem computacional seja por elementos finitos, fuzzy ou redes bayesianas. 
10. BIBLIOGRAFIA

AB'SABER, A. N. O suporte geoecológico das florestas beiradeiras (ciliares). In: Matas ciliares: conservação e recuperação. R. R. RODRIGUES \& H. F. LEITE FILHO (Org.). $2^{a}$ ed. São Paulo: EdUSP/ FAPESP. p. 235-247, 2001.

ABAM, T. K. S. Aspects of alluvial river bank recession: some examples from the Niger delta. Environmental Geology. n. 31, v. 3/4, $211-220,1997$.

ABREU, A. E. S. \& AUGUSTO FILHO, O. Mapeamento geotécnico para gestão municipal. In: Geoténica. Revista Luso-brasileira de Geotecnia. Portugal: SPG/ ABMS/ABGE. n. 115, p. 45-80, 2009.

ABREU, A. E. S. Mapeamento geotécnico para gestão municipal - abordagem combinando três métodos distintos e sua aplicação em Analândia (SP). 2007. Dissertação (Mestrado em Engenharia Civil, Geotecnia) - . São Carlos: Escola de Engenharia de São Carlos, Universidade de São Paulo, 2007.

ABREU, A. E. S. Mapeamento geotécnico para gestão municipal: abordagem combinando três métodos distintos e sua aplicação em Analândia (SP). 2007. Dissertação (Mestrado em Geotecnia) - Escola de Engenharia de São Carlos, Universidade de São Paulo, São Carlos, 2007.

ABREU, J. R. S. P. Dinâmica da Serapilheira em um Trecho de Floresta Atlântica Secundária em Área Urbana do Rio de Janeiro. 2006. Dissertação (Mestrado em Ciências Ambientais e Florestais) - Universidade Federal Rural do Rio de Janeiro, Seropédica, 2006.

AFZALIMEHR, H.; SUI, J; MOGHBEL, R. Hydraulic parameters in channels with wall vegetation and gravel bed. International Journal of Sediment Research. v. 25, p. 81-90, 2010.

Agência Nacional de Energia Elétrica. Guia de práticas sedimentométricas. N. O. Carvalho; N. P. Filizola Júnior; P. M. C. Santos; J. E. F. W. Lima (org.). Brasília: ANEEL, 2000.

AGUIAR, A. M. Análises hidrogeomorfológicas e hidrossedimentológicas para comparação de duas bacias hidrográficas contribuintes do reservatório de Itaipu. 2009. Dissertação (Mestrado em Geografia Física) - Faculdade de 
Filosofia, Letras e Ciências Humanas, Université de São Paulo, São Paulo, 2009.

AHMED, A. A. \& FAWZI, A. Meandering and bank erosion of the River Nile and its environmental impact on the area between Sohag and El-Minia, Egypt. Arab J. Geoscience. (ORIGINAL PAPER). 11p., 2009

ALBUQUERQUE SOBRINHO, E. J. \& ANDRADE MEIRELES, A. J. Uma lagoa urbana em processo de extinção: propostas para recuperação da qualıdade ambıental da lagoa da Maraponga, Fortaleza, Ceará / Brasıl. Geonotas (UEM), v. 8., 2004. Disponível em: http://www.dge.uem.br/geonota, ALBUQUERQUE SOBRINHO, E. J. \& POLIVANOV, H. Comportamento geomecânico de edificação em terreno sedimentar e suas repercussões geológico-geotécnicas: Copacabana/ RJ. In: X CONGRESSO DA ABEQUA. Guaraparí: ABEQUA. (cd-rom), 2005.

ALBUQUERQUE SOBRINHO, E. J. Análise do monitoramento geológicogeotécnico da obra de ampliação do metrô do Rio de Janeiro - RJ. 2006. Dissertação (Mestrado em Geologia) - Instituto de Geociências, Universidade Federal do Rio de Janeiro, Rio de Janeiro, 2006.

ALBUQUERQUE SOBRINHO, E. J. Diagnóstico sócio-ambiental do ambiente lacustre da Maraponga Fortaleza/ CE. In: XVIII ENCONTRO REGIONAL DE ESTUDOS GEOGRÁFICOS/ ENCONTRO ESTADUAL DE GEOGRAFIA DO RN, 2001, Natal/ RN. XVIII ENCONTRO REGIONAL DE ESTUDOS GEOGRÁFICOS/ ENCONTRO ESTADUAL DE GEOGRAFIA DO RN, 2001.

ALBUQUERQUE SOBRINHO, E. J. et. al. Análise do uso e ocupação do córrego das cruzes e seus impactos ambientais: Santo Antonio do Aracanguá/SP. IN: IX Encontro Nacional de Engenharia de Sedimentos - ENES. Brasilia: ABRH, p.11., 2010.

ALLOWAY, B.J. \& AYRES, D.C. Chemical Principles of Environmental Pollution, $2^{\text {nd }}$ ed., New York: Chapman \& Hall, 1997.

ALMEIDA, C. L. et al. Estimativa do potencial erosivo no município de Acopiara, CE, utilizando as ferramentas de SIG. IN: IX Encontro Nacional de Engenharia de Sedimentos - ENES. Brasilia: ABRH, p.12, 2010. 
ALMEIDA, F. F. M. Síntese sobre a tectônica da Bacia do Paraná. In: Simpósio Regional de Geologia, 3, 1981, São Paulo. Atas do Simpósio Regional de Geologia. São Paulo: SBG. v. 1. 1-20, 1981.

ALVES, J. M. P. \& CASTRO, P. T. A. Influência de feições geológicas na morfologia da bacia do Rio do Tanque (MG) baseada no estudo de parâmetros morfométricos e análise de padrões de lineamentos. Revista Brasileira de Geociências. v. 33, n. 2, p. 117-124, 2003.

AMORIM, R. S. S. et al. Avaliação do desempenho dos modelos de predição da erosão hídrica USLE, RUSLE e WEPP para condições edafoclimáticas brasileiras. 2003. Tese (Doutorado em Engenharia Agrícola) - Universidade Federal do Viçosa, Viçosa, 2003.

AMORIM, R. S. S. et al. Avaliação do desempenho dos modelos de predição da erosão hídrica USLE, RUSLE e WEPP para diferentes condições edafoclimáticas do Brasil. Eng. Agríc., Jaboticabal. v. 30, n.6, p. 1046-1049, 2010.

ANA, Agência Nacional de Águas. Banco de dados HidroWEB. 2004. Disponível em: http://www.ana.gov.br.

ANGELO, R. J. et al. Relações entre erodibilidade e a agregação, granulometria e características químicas de solos brasileiros.In: Revista Brasileira de Ciências do Solo. p.133-138, 1984.

ANGRADI, T. The large and Great River "reference problem": Surmounting the obstacles. In: Great Rivers Reference Condition Workshop. Cincinnati: The U.S. Environmental Protection Agency and The Council of State Governments. 2006. Acessado em 02/03/2011. Disponível em: http://www.epa.gov/emap2/greatriver/rcw/LGRRP.pdf ARID, F. M.; BARCHA, S. F.; MEZZALIRA, S. Contribuição ao estudo da Formação Caiuá. São Paulo: Rev. IG. 2. 1: p. 5-20, 1981.

AROVIITA, J. et al. A priori typology-based prediction of benthic macroinvertebrate fauna for ecological classification of rivers. Environmental Management. n. 42, p. 894-906, 2008. 
ARRAES, C. L.; BUENO, C. R. P.; PISSARRA, T. C. T. Estimativa da erodibilidade do solo para fins conservacionistas na microbacia Córrego do Tijuco, SP. Biosci. J., Uberlândia, v. 26, n. 6, p. 849-857, 2010.

Associação Brasileira de Normas Técnicas. NBR 13.133: Execução de levantamento topográfico. Rio de Janeiro: ABNT, 1994.

Associação Brasileira de Normas Técnicas. NBR 13441: Solos e rochas. Rio de Janeiro: ABNT, 1995.

Associação Brasileira de Normas Técnicas. NBR 5734: Especificação de peneiras para ensaio. Rio de Janeiro: ABNT, 1989.

Associação Brasileira de Normas Técnicas. NBR 6502: Rochas e Solos. Rio de Janeiro: ABNT, 1995.

Associação Brasileira de Normas Técnicas. NBR 7181: Solo - análise granulométrica. Rio de Janeiro: ABNT, 1984.

AVILA, A. L. et al. Caracterização da vegetação e espécies para recuperação de mata ciliar, Ijuí, RS. Ciência Florestal, Santa Maria, v. 21, n. 2, p. 251-260, 2001.

BACELLAR, L. A. P. Condicionantes geológicos, geomorfológicos e geotécnicos dos mecanísmos de voçorocamento na Bacia do Rio Maracujá, Ouro Preto - MG. 2000. Tese (Doutorado em Engenharia Civil). Universidade Federal do Rio de janeiro, Rio de janeiro, 2000.

BALESTRINI, R.; MARCELLO CAZZOLA, M.; BUFFAGNI, A. Characterising hydromorphological features of selected Italian rivers: a comparative application of environmental índices. Hydrobiologia. n. 516, p. 365-379, 2004.

BANCO DO NORDESTE. Manual de impactos ambientais: orientações básicas sobre aspéctos ambientais de atividades produtivas. M. C. O. Dias et al. (org.). Fortaleza: Banco do Nordeste, 1999.

BARBOUR, M. T. \& PAUL, M. J. Adding value to water resource management through biological assessment of Rivers. Hydrobiologia. n. 651, p. 17-24, 2010.

BARROS, L. F. P; RAPOSO, A. L.; MAGALHÃES JÚNIOR, A. P. Condicionantes antrópicos na dinâmica erosivo-deposicional da bacia do Rio Maracujá - 
Quadrilátero Ferrífero/MG. 2009. In: XIII Simpósio de Geografia Física (SBGFA). $15 p$.

Disponível

em:

http://www.geo.ufv.br/simposio/simposio/trabalhos/trabalhos_completos/eixo3/0 62.pdf

BASTOS, C. A. B.; MILITITSKY, J. ; \& GEHLING, W. A avaliação da erodibilidade dos solos sob o enfoque geotécnico - pesquisas e tendências. In: Teoria e Prática na Engenharia Civil, n. 1, p.17-25, 2000.

BATEZELLI, A. et al. Análise estratigráfica aplicada à Formação Araçatuba (Grupo Bauru - $\mathbf{K}_{\mathbf{S}}$ ) no centro-oeste do Estado de São Paulo. Geociências. 22. P. 5-9, 2003.

BECKER, L. \& YEH, W. Identification of multiple reach channel parameters.

Water Resour. Res.v. 9, n. 2, p. 326-35, 1973.

BECKER, L. \& YEH, W. Identification of parameters in unsteady open channel flow. Water Resour. Res. v. 8, n. 4, p. 956-65, 1973.

BERTONI, J. \& LOMBARDI NETO, F. Conservação do solo. 4ª Ed. São Paulo: Ícone, 1999.

BHAKAL, L.; DUBEY, B.; SARMA, A. K. Estimation of bank erosion in the River Brahmaputra near Agyathuri by using Geographic Information System. Journal of the Indian Society of Remote Sensing, n. 33, v. 1, p. 81-82, 2005.

BIELAVSKY, M. Uso da terra na área do reservatório Guarapirangua. Monografia (Graduação em Geografia), Universidade de São Paulo, São Paulo, 2002.

BIENIAWSKI, Z. T. The geomechanical classification in rock engineering applications. In: $4^{\text {th }}$ Congress of the Int. Society for Rock Mech. 3v. Rotterdam: Balkemaa, 1979.

BIGARELLA, J. J. \& MAZUCHOWSKI, J. Z. Visão integrada da problemática da erosão. Curitiba: ABAE/ABGE, 1985.

BIRGAND, F. Evaluation of QUAL2E. Acessado em 14/03/2011. Disponível em: http://www.bae.ncsu.edu/www3/acad/Regional-Bulletins/ModelingBulletin/qual2e.html

BISWAS, S.; SUDHAKAR, S.; DESAI, V. R. Prioritisation of subwatersheds based on morphometric analysis of drainage basin: a remote sensing and GIS Approach. J. Indian Soc Remote Sens. v. 27, p. 155-166, 1999. 
BORDAS, M.P., LANNA, A.E., SEMMELMANN, F.R. Evaluation des risques d'erosion et de sedimentation au Bresil a partir de bilans sedimentologiques rudimentaires. In:Bordas, M.P.,Walling, D.E. (Eds.), Sediment Budgets. IAHS, Porto Alegre, pp. 359-368, 1988.

BOTELHO, R. G. M. \& GUERRA, A. J. T. Erosão dos solos. In: CUNHA, S. B. da; GUERRA, A. J. T. Geomorfologia do Brasil. 3aㅗ ed. Rio de Janeiro: Bertrand Brasil. pp.181-220, 2003.

BOTSCHEK, J. et al. Piping and erodibility of loessic soils in bergisches land, Nordrhein - Westfalen. J. Plant. Nutr. Soil Sci. n. 165, p. 241-246, 2002.

BRAILE, P. M. \& CAVALCANTE, J. E. W. A. Manual de tratamento de águas residuárias industriais. São Paulo: CETESB,1979.

BRAIONI, M. G. et al. New environmental index for assessing river bank quality: the case or River Adige (north-east Italy). In: Proceeding of International Workshop on the Ecology and Management of Aquatic-Terrestrial Ecotones. G. L. Link \& R. J. Naiman (org.). Seattle: University of Washington, pp. 86-94, 1994.

BRAIONI, M. G. et al. New environmental indices for assessing bank quality in restoration and sustainable management of a river: the method. Ecohydrology \& Hydrobiology. n. 1, v. 1/2, p. 133-154, 2001.

BRIERLEY, G. \& FRYIRS K. River styles, a geomorphic approach to catchment characterisation: implications for river rehabilitation in Bega Catchment, New South Wales, Australia. Environmental Management. n. 25, v. 6, p. 661$679,2000$.

BRIERLEY, G. et al. Application of the River Styles framework as a basis for river management in New South Wales, Australia. Applied Geography. n. 22, p. 91-122, 2002.

BRIGANTE, J. et al. Caracterização física, química e biológica da água do Rio Mogi-Guaçu: um estudo no Rio Mogi-Guaçu. In: Limnologia fluvia. J. Brigante \& E. L. G. Espíndola (Org.). São Carlos: RiMa, pp. 77-84, 2003.

CABRAL, I. L. L. \& PRADO, R. J. Aspectos geomorfológicos e caracterização química e estrutural de formações concrecionárias da depressão periférica (RS). Revista Brasileira de Geomorfologia, v.9, n.2, p.39-51, 2008. 
CAETANO, G. T. Estudo da adequação do uso do método acústico Doppler para medições de vazão a pequenos e médios cursos d'água. 2000. Dissertação (Mestrado em Recursos Hídricos). Escola de Engenharia de Itajubá, Itajubá, 2000.

CALLISTO, M. et al. Aplicação de um protocolo de avaliação rápida da diversidade de habitats em atividades de ensino e pesquisa (MG-RJ). Acta IImnológica Brasileira, n. 34, p. 91-97, 2002.

CAMBRA, M. F. E. S. \& COELHO NETO, A. L. A cidade do Rio de Janeiro e as chuvas de março/93: (des)organização urbana e inundações. Anuário do Instituto de Geociências. n. 20, p. 55-74, 1997.

CAMPOS, M. L.; ALMEIDA, J. A.; SOUZA, L. S. Avaliação de três áreas de solo construído após mineração de carvão a céu aberto em Lauro Muller, Santa Catarina. Rev. Bras. Ciênc. Solo. n. 27, v. 6, p. 1123-1137, 2003.

CANDIDO, L. W. \& ZAINE, J. E. Identificação e mapeamento de cavas e pilhas de bota-fora de mineração como unidade geológico-geotécnica no município de Estiva Gerbi - SP, Brasil. Guarulhos: Revista Universidade de Guarulhos/Geosciências. n. 10, v. 6, 35-44, 2005.

CANT, D. J. Fluvial facies models. In: Sandstone depositional environments. P. A. Scholle \& H. C. Henkyns (Org.). American Association of Petroleum Geologists Memoire. n. 31. 115-138, 1982.

CARDOSO, E. G. et al. Sistema radicular da soja em função da compactação do solo no sistema de plantio direto. Pesq. Agropec. Bras., Brasília, v.41, n.3, p. 493-501, 2006.

CARVALHO, E. M. et al. Utilização do geoprocessamento para avaliação de riscos de erosão do solo em uma bacia hidrográfica: estudo de caso da bacia do Rio Passa Cinco/SP. In: III Simpósio Brasileiro de Ciências Geodésicas e Tecnologias da Geoinformação. Recife: III Simpósio Brasileiro de Ciências Geodésicas e Tecnologias da Geoinformação, p. 01-08, 2010. Disponível

em: http://www.ufpe.br/cgtg/SIMGEOIII/IISIMGEO_CD/artigos/CartografiaeSIG/SIG /A_101.pdf. 
CARVALHO, I. S. A bacia Bauru. In: Geologia história. Ignácio Machado Brito. (Org.). Goiania: EdUFGO, p. 168-178, 2000.

CARVALHO, N. O. et al. Atualização dos estudos sedimentológicos do Rio Madeira, RO - Período 2003/2006. IN: IX Encontro Nacional de Engenharia de Sedimentos - ENES. Brasilia: ABRH, p.12, 2010.

CARVALHO, N. O. et al. Guia de avaliação de assoreamento em reservatórios. Brasilia: ANEEL, 2000.

CARVALHO, N. O. et al. Guia de práticas sedimentométricas. Brasilia: ANEEL, 2000.

CELÍLIO, R. A. et al. Aplicação dos modelos RUSLE e WEPP para a estimativa da erosão hídrica em microbacia hidrográfica de Viçosa (MG). Revista Verde. 4. 2: 39-45, 2009.

CEREDA JUNIOR, A. Mapeamento da fragilidade ambiental na bacia do Ribeirão do Monjolinho - São Carlos - SP - Unilizando ferramentas de geoprocessamento. 2006. Dissertação (Mestrado em Engenharia Urbana). Universidade Federal de São Carlos, São Carlos, 2006.

CERRI, L. E. S. et al. Cartas e mapas geotécnicos de áreas urbanas: reflexões sobre as escalas de trabalho e proposta de elaboração vom o emprego do método de detalhamento progressivo. In: Congresso Brasileiro de Geologia de Engenharia, 8., Rio de Janeiro: ABGE, v. 2, p. 537-548, 1996.

CHEVALLIER, P. Aquisição e Processamento de Dados. IN: Hidrologia: Ciência e Aplicação. C. E. M. TUCCI (Org.). Porto Alegre: Editora da UFRGS/ABRH. 485 $-525,2003$.

CHITALE, S. V. River channel patterns. Jornal Hydraulics Division. ASCE, n. 96, p. 1, p. 201-221, 1970.

CHO, J. H. \& HA, S. R. Parameter optimization of the QUAL2K model for a multiple-reach river using an influence coefficient algorithm. Science of the Total Environment. v. 408, p.1985-1991, 2010.

CHRISTOFOLETTI, A. Geomorfologia fluvial. v. 1. São Paulo: Edgard Blucher, 1981.

CHRISTOFOLETTI, A. Geomorfologia. 2ª Ed. São Paulo: Edgard Blucher, 1980. 
$\mathrm{CHURCH}, \mathrm{M}$. \& JONES, D. Channel bars in gravel-bed streams. In: Gravel Bed Streams. R. D. Hey, J. C. Bathurst and C. R. Thorne. Chichester, UK, Wiley: pp. 291-338, 1992.

COELHO NETTO, A. L. \& AVELAR, A. S. Hidrologia de encosta na interface com a geomorfologia. In: Geomorfologia: exercícios, técnicas e aplicações. S. B. Cunha \& A. J. T. Guerra (Org.). $2^{a}$ ed. Rio de Janeiro: Bertrand Brasil, pp. 103138, 2002.

COELHO NETTO, A. L. Hidrologia de encosta na interface com a geomorfologia. In: Geomorfologia: uma atualização de bases e conceitos. A. J. T. Guerra \& S. B. Cunha (orh.). 4ª ed. Rio d Janeiro: Bertrand Brasil, pp. 93-148, 2001.

COLLARES, E. G. Avaliação de alterações em redes de drenagem de microbacias como subsídio ao zoneamento geoambiental de bacias hidrográficas: aplicação na bacia hidrográfica do Rio Capivari - SP. 2000. 2v. Tese (Doutorado em Geotecnia). Escola de Engenharia de São Carlos, Universidade de São Paulo, São Carlos, 2000.

COMPANHIA ESTADUAL DE TECNOLOGIA DE SANEAMENTO AMBIENTAL Legislação ambiental. Controle de poluição ambiental, Estado de São Pauo (atualizado em dezembro de 1998). São Paulo: Série Documentos/ Secretaria de Meio Ambiente, 1999.

COMPANHIA ESTADUAL DE TECNOLOGIA DE SANEAMENTO AMBIENTAL. Índice de Qualidade das Águas. Acessado em 11/03/2011. Disponível em: http://www.cetesb.sp.gov.br/agua/aguas-superficiais/42-indice-de-qualidadedas-aguas-\%28iqa\%29.

CONSELHO ESTADUAL DE RECURSOS HÍDRICOS Plano estadual de Recursos Hídricos: 2004 / 2007 Resumos. São Paulo: DAEE, 2006.

CORREA, G. T. \& SOUZA FILHO, E. E. Avaliação dos processos de erosão marginal no arquipélago floresta japonesa (Alto Rio Paraná). Geografia (Londrina). v. 18, p. 2, 1-20, 2009.

CORREAA, I. C. S. Topografia Aplicada à Engenharia Civil. 12ª ed. Porto Alegre: Dept. de Geodésia/ UFRGS, 137p., 2010.

COSTA, A. N.; POLIVANOV, H. \& ALVES, M. G. Mapeamento GeológicoGeotécnico Preliminar, Utilizando Geoprocessamento, no Município de 
Campos dos Goytacazes, Estado do Rio de Janeiro. Anuário do Instituto de Geociências - UFRJ. v. 31, n. 1, p. 50-64, 2008.

COSTA, I. G. D. D. Análise do assoreamento no reservatório de Três Irmãos SP, utilizando dados topobatimétricos, hidrológicos e técnicas de geoprocessamento. 2009. Dissertação (Mestrado em Ciências da Engenharia Ambiental), Escola de Engenharia de São Carlos, Universidade de São Paulo, São Carlos, 2009.

COSTA, O. V. 2000. Impacto animal sobre o componente abiótico do solo: ciclagem de nutrientes e compactação. Viçosa: Departamento de Zootecnia, Universidade Federal de Viçosa, 30p. Disponível em: http://www.forragicultura.com.br/arquivos/IMPACTOANIMALCOMPONENTEAB IOTICO.pdf

$\operatorname{cosTA}, T$. C. C. et al. Vulnerabilidade de sub-bacias hidrográficas por meio da equação da perda de solo e da integração de parâmetros morfométricos, topográficos, hidrológicos e de uso/cobertura da terra no Estado do Rio de Janeiro, Brasil. In: Revista Ambiente \& Água - An Interdisciplinay Journal of Applied Science. v. 4, n. 1, p. 93-116, 2009.

CPRM. Geologia da borda sudeste da Bacia do Paraná. Acessado em: 08/12/2009.

http://www.cprm.gov.br/Aparados/ap_geol_pag01.htm.

CREPANI et al. Sensoriamento Remoto e Geoprocessamento Aplicados ao Zoneamento Ecológico Econômico e ao Ordenamento Territorial. São José dos Campos: INPE (INPE 8454-RPQ/722), 2001.

CREPANI, E.; MEDEIROS, J, S.; PALMEIRA, A. F. Intensidade pluviométrica: uma maneira de tratar dados pluviométricos para análise da vulnerabilidade de paisagens à perda de solo. São José dos Campos: INPE (INPE 11237-RPQ/760), 2004.

CUNHA, S. B. \& GUERRA, A. J. T. Degradação ambiental. In: Geomorfologia e meio ambiente. A. J. T. Guerra \& S. B. Cunha (org.). Rio de Janeiro: Bertrand Brasil, pp. 337-379, 1996. 
CUNHA, S. B. Geomorfolofia fluvial. In: Geomorfologia: uma atualização de bases e conceitos. A. J. T. Guerra \& S. B. Cunha (org.). $4^{\text {a }}$ ed. Rio de Janeiro: Bertrand Brasil, pp. 211-252, 2001.

DANTAS, A. A. A.; CARVALHO, L. G.; FERREIRA, E. Classificação e tendências climáticas em Lavras, MG. Ciênc. agrotec., Lavras, v. 31, n. 6, p. 1862-1866, 2007.

DAVENPORT, A. J.; GURNELL, A. M.; ARMITAGE, P. D. Habitat survey and classification of urban rivers. River Res. Applic. n. 20, p. 687-704, 2004.

de PAULO, J. R. ; BACELLAR, L. A. P.; DANDERFER FILHO, A. Avaliação de áreas de risco geológico na Bacia de Vargem das Flores, município de Contagem e Betim - MG. Solos e Rochas. São Paulo: ABMS/ABGE. n. 28, v. 2, p. 205-219, 2005.

de ROO, A. P. J. et al. LISEM: a new physically-based hydrological and soil erosion model in a GIS-environment, theory and implementation. In: Variability in stream erosion and sediment transport. L. J. Olive, R. J. Loughran, J. A. Kesby (org). Great Britain: IAHS. v. 224, p. 439-448, 1994.

De ROSE, R. C. \& BASHER, L. R. Measurement of river bank and cliff erosion from sequential LIDAR and historical aerial photography. Geomorphology. n. 126, p. 132-147, 2011.

DEERE, D. U. Geological considerations, rock mechanics in engineering practice. R. G. Stagg \& D. C. Ziekiewicz (Org.). NY: Wiley, pp. 1-20, 1964.

DEERE, D. U. Quality Rock Designation (RQD) after twenty years. U.S. Army Corps of egnineers contract report GL-89-1. Waterways Experiment Station. Viksburg: MS, 67pp., 1989.

della FONTANA, G, \& MARCHI, L. Slope area relationships and sediment dynamics in two alpine streams. Hydrol. Process. v. 17, p. 73-87, 2003.

DEMATTÊ, J.A.M. \& DEMÉTRIO, V.A. Fotointerpretação de padrões de drenagem de bacias hidrgráficas na caracterização de solos desenvolvidos de rochas eruptivas básicas no Estado do Paraná. Sci. Agrícola. v. 52, n. 3, p. 569-577, 1995. 
DENG, Y. X.; WILSON, J. P.; SHENG, J. Effects of Variable Attribute Weights on Landform Classification. Earth Surf. Process. Landforms. v. 31, p. 14521462, 2006.

DEPARTAMENTO NACIONAL DE PRODUÇÃO MINERAL. Geologia do Brasil. C. Schobbenhaus; D. A. Campos; G. R. Derze; H. E. Asmus (Coord.). Brasília: DNPM, 1984.

DILLENBURG, A. K. A importância do monitoramento ambiental naavaliação da qualidade de um rio - estudo de caso - Mercedes, PR. Revista Urutágua. v. 12. p. $1-10,2007$.

DIODATO, N. Geostatistical uncertainty modelling for the environmental hazard assesment during single erosive rainstorm events. Environmental Monitoring and Assessment. v. 105, p. 25-42,2005.

DIRECTIVE, 2000/60/EC. Water Framework Directive of the European Parliament and of the Council of 23 October, 2000.

DOEGLAS, D. J. The structure of sedimentary deposits of braided rivers. Sedimentology, v.1, p. 167-193, 1962.

DOTTO, S. E.; SANTOS, R. F.; SINGER, E. M. Determinação de um índice de qualidade de água para algumas culturas irrigadas em São Paulo. Bragantia, Campinas, v.55, n.1, p.193-200, 1996.

DURY, G. H. Relation of morphometry to runoff frequency. In: Water, earth and man. R. J. Chorley (ed.). Londres: Methuen \& Co. 419-430p., 1969.

EMPRESA BRASILEIRA DE PESQUISA AGROPECUÁRIA. Cultivo do Algodão Irrigado. Acessado em 08/02/2011. Disponível em: http://sistemasdeproducao.cnptia.embrapa.br/FontesHTML/Algodao/Algodaolrri gado/solos.htm.

EMPRESA BRASILEIRA DE PESQUISA AGROPECUÁRIA. Manual de métodos de análise de solo. Centro Nacional de Pesquisa de Solos. $2^{a}$ ed. Rio de Janeiro: EMBRAPA, 212p., 1997.

EMPRESA BRASILEIRA DE PESQUISA AGROPECUÁRIA. Reunião técnica de levantamento de solos, 10., 1979, Rio de Janeiro. Súmula... Rio de Janeiro, 83 p., 1979. 
ENVIRONMENTAL PROTECTION AGENCY. Biological criteria for the protection of aquatic life. Division of Water Quality Monitoring Assessment. Columbus, Ohio, v. 1-III, p.120., 1987.

ENVIRONMENTAL PROTECTION AGENCY. Stream flow. In: ENVIRONMENTAL PROTECTION AGENCY. Volunteer stream monitoring: a methods manual. Washington: EPA, pp. 134-138, 1997.

ESPINDOLA, G. M. et. al. Agricultural land use dynamics in the Brazilian Amazon based on remote sensing and census data. Applied Geography. v. 32, p. 240-252, 2012.

EVETTE, A. et al. History of Bioengineering Techniques for Erosion Control in Rivers in Western Europe. Environmental Management. n. 43, p.972-984, 2009.

FERNANDES, A. Fitogeografia brasileira. $2^{\mathrm{a}}$ ed. Fortaleza: Multigraf, 2000.

FERNANDES, D. O. Erodibilidade de matérias inconsolidados da bacia do Ribeirão Samambaia (Região de São Pedro -SP). Dissertação (Mestrado). Escola de Engenharia de São Carlos, Universidade de São Paulo, São Carlos, 2003.

FERNANDES, L. A. \& COIMBRA, A. M. Revisão estratigráfica da parte oriental da Bacia Baruru (Neocretaceo). Revista Brasileira de Geociências. 30. 4: p. 717-728, 2000.

FERNANDES, L. A. Mapa litoestratigráfico da parte oriental da bacia Bauru (PR, SP, MG), escala 1:1.000.000. Boletim Paranaense de Geociências. v.55, p. 5366, 2004.

FERREIRA, G. C. Interferências ambientais e legais entre as atividades de mineração e a implantação e operação de gasodutos. Tese (Livre-docente em Lavra de Minas e Tratamento de Minérios). Rio Claro: UNESP, 107p., 2011.

FERREIRA, M. D. \& PEJON, O. J. Análise temporal das feições erosivas lineares: São Pedro/SP. In: Cartografia Geotécnica e Geoambiental. conhecimento do meio físico: base para a sustentabilidade. O. J. Pejon \& L. V. Zuquette (org.). $5^{\circ}$ Simpósio Brasileiro de Cartografia Geotécnica e Geoambiental. São Carlos: Suprema Gráfica Editora. p. 131-139, 2004. 
FIGUEIREDO, M. A. G. Avaliação e mapeamento de áreas prioritárias para a recuperação e a preservação dos recursos hídricos no município de Cachoeira de Minas - MG, com o auxilio de geoprocessamento. 2009. Monografia (Especialização em Gerenciamento Municipal de Recursos Hídricos). Instituto de Ciências Biológicas, Universidade Federal de Minas Gerais, Belo Horizonte, 2009.

FILIZOLA, N. O fluxo de sedimentos em suspensão nos rios da Bacia Amazônica brasileira. Agência Nacional de Energia Elétrica, Brasília, p.63, 1999.

FONTES, S. B. Estudo geoambiental da bacia do Rio Pardo, a partir da compartimentação em ottobacias: escala 1:100.000. 2004. 2v. Tese (Doutorado em Geotecnia) Escola de Engenharia de São Carlos, Universidade de São Paulo, São Carlos, 2004.

FRANCESCHET, I. et al. Erosão hídrica e infiltração de água no solo em sistemas de manejo na microbacia do Rio Caiabi - Bacia Amazônica. IN: IX Encontro Nacional de Engenharia de Sedimentos - ENES. Brasilia: ABRH, p.14, 2010.

FRYIRS, K. Guiding principles for assessing geomorphic river condition: application of a framework in the bega catchment, South Coast, New South Wales, Australia. Catena. v. 53, p. 17-52, 2003.

FULAZZAKY, M. A.; SEONG, T. W.; MASIRIN, M. I. M. Assessment of Water Quality Status for the Selangor River in Malaysia. Water Air Soil Pollut. v. 205, p. 63-77, 2010.

Geological Society Engineering Group Working Party Report. Tropical residual soil. The Quartely Journal of Engineering Geology. v. 23, n. 1, p. 4-101, 1990.

GIBBS, R. J. Amazon rivers: environmental factors that control its dissolved and suspended load. Science. v. 156, p. 1734-1737, 1967.

GIBOSHI, M.L. Desenvolvimento de um sistema especialista para determinar a capacidade de uso da terra. 1999. Dissertação (Mestrado em Planejamento e Produção Agropecuária). Faculdade de Engenharia Agrícola, Universidade Estadual de Campinas, Campinas, 1999. 
GILSANZ, J. P. Morfometría o geometría del relieve. In: Geomorfología. Principios, métodos y aplicaciones. J. P. Gilsanz (org.). Madrid: Ruenda S. L. p. 51-62, 1996.

GONÇALVES, F. A. Erosividade das chuvas no Estado do Rio de Janeiro. 2002. Dissertação (Mestrado em Engenharia Agrícola). Universidade Federal de Viçosa, Viçosa, 2002.

GONÇALVES, W. G. et al. Sistema radicular de plantas de cobertura sob compactação do solo. Eng. Agríc., Jaboticabal, v.26, n.1, p.67-75, 2006.

GOULDING, M., BARTHEM, R., FERREIRA, E. The Smithsonian Atlas of the Amazon. Smithsonian Institution press, Washington, 2003.

GOURNELLOS, T; EVELPIDOU, N.; VASSILOPOULOS, A. Developing an Erosion Risk Map Using Soft Computing Methods (Case Study at Sifnos Island). Natural Hazards. v. 31, p. 63-83, 2004.

GRIGIO, A. M. Aplicação do sensoriamento remoto e sistemas de informação geográfica na determinação da vulnerabilidade natural e ambiental do Município de Guaramé (RN): simulação de risco às atividades da indústria petrolífera. 2003. Dissertação (Mestrado em Geodinâmica e Geofísica), Universidade Federal do Rio Grande do Norte, Natal: UFRN, 2003.

GROSSI, C. H. Diagnóstico e monitoramento ambiental da microbacia hidrográfica do Rio Queima-Pé, MT. Tese (Doutorado em Agronomia/Energia na Agricultura). Faculdade de Ciências Agronômicas, Universidade Estadual Paulista "Júlio de Mesquita Filho", 2006.

GUERRA, A. J. T. Processos erosivos nas encostas. In: Geomorfologia: uma atualização de bases e conceitos. A. J. T. Guerra \& S. B. Cunha (orh.). $4^{a}$ ed. Rio d Janeiro: Bertrand Brasil, pp.149-209, 2001.

HANCOCK, G. R. The impact of depression removal on catchment geomorphology, soil erosion and landscape evolution. Earth Surf. Process. Landforms. v. 33, p. 459-474, 2008.

HANNAFORD, M. J.; BARBOUR, M. T.; RESH, V. H. Training reduces observer variability in visual-based assessments of stream habitat. J. N. Am. Benthol. Soc. v. 16, n. 4, p. 853-860, 1997. 
HARGETT, E. G., ZUMBERGE, J. R., HAWKINS, C. P. Development of a RIVPACS model for wadeable streams of Wyoming. Wyoming: Wyoming Departament of Environmental Quality/ Water Quality Division, 27p., 2005.

HERING, D. et al. Preface. Integrated assessment of running waters in Europe. Hydrobiologia. v. 516, p. vii-ix, 2004.

HILL, M.O. TWINSPAN-a FORTRAN program for arranging multivariate data in an ordered two-way table by classification of the individuals and attributes. New York: Cornell University, Ithaca, 90p., 1979.

HILLDALE, R. C. \& RAFF, D. Assessing the ability of airborne LiDAR to map river bathymetry. Earth Surf. Process. Landforms. v. 33, 773-783, 2008.

HILLS, R. C. The determination of the infiltration capacity on field soils using the cylinder infiltrometer. British Geomophological Group, Technical Bulletin, v. 3, 25p., 1970.

HOLMES, N.T.H.; BOON, P.J.; ROWELL, T.A. A revised classification system for British rivers based on their aquatic plant communities. Aquatic Conserv: Mar. Freshw. Ecosyst. v. 8, p. 555-578, 1998.

HORTON, R. E. Erosional development of streams and their drainage basins: hydrophysical approach to quantitative morphology. Bull. Geol. Soc. Am. v. 56, p.275-370, 1945.

HORTON, R. E. The role of infiltration in the hydrological cyle. Trans. Am. Geophys. Union. v. 14, p. 446-460, 1932.

HUANG, Y. et al. Spatial Integrated Analysis on Water Erosion of Yellow River China. Geoscience and Remote Sensing Symposium, 2002. IGARSS 2002. IEEE International. v. 4, p. 2411-2413, 2002.

IAEG COMMISSION "ENGINEERING GEOLOGYCAL MAPPING". Classification of rocks and soils for engineering geology mapping. Part 1: rock and soil materials. Krefeld. v. 19. p. 123-371, 1979.

IMESON, A. \& CURFS, M. Erosão do solo. 2010. Acessado em 20/01/2011. Disponível em: http://geografia.fcsh.unl.pt/lucinda/Leahes flets/B1_Leaflet_PT.pdf 
INSTITUTO BRASILEIRO DE GEOGRAFIA E ESTATÍSTICA. Manuais Técnicos em Geociências № 4. Manual Técnico de Pedologia. $2^{\underline{a}}$ ed. Rio de Janeiro: IBGE, 2007.

INSTITUTO DE PESQUISAS TECNOLÓGICAS DO ESTADO DE SÃO PAULO. Mapa Geomorfológico do Estado de São Paulo. Escala - 1:1.000.000. São Paulo, IPT. v.1., 1981a. 94p.

INSTITUTO DE PESQUISAS TECNOLÓGICAS DO ESTADO DE SÃO PAULO. Mapa Geológico do Estado de São Paulo. Escala - 1:500.000. São Paulo, ITP. v.1. 1981b. 126p.

JEPSEN, R.; ROBERTS, J.; LICK, W. Effects of bulk density on sediment erosion rates. Water, Air an Soil Pollution. v. 99, p. 21-31, 1997.

JOHNSON, K. K. \& LOVING, B. L. Use of an Acoustic Doppler Current Profiler (ADCP) to Measure Hypersaline Bidirectional Discharge. Acessado em 25/07/2011.

Disponível

em:

http://hydroacoustics.usgs.gov/publications/KJBiflow.pdf

JUNG, K.; J. D. NIEMANN; HUANG, X. Under what conditions do parallel river networks occur? Geomorphology. v. 132, p. 260-271, 2011.

KANNEL, P. R. et al. Application of water quality indices and dissolved oxygen as indicators for river water classification and urban impact assessment. Environ. Monit. Assess. v. 132, p. 93-110, 2007.

KAYO, E. K. \& SECURATO, J. R. Método Delphi: fundamentos, críticas e vieses. Cadernos de Pesquisa em Administração. v. 1, n. 4, 51-61, 1997

KENT, M. \& COKER, P. Vegetation description and analysis - a practical approach. John Willey \& Sons. 1994.

KÖPPEN, W. \& GEIGER, R. Klima der Erde (Climate of the Earth). Wall Map 1:16 Mill. Klett-Perthes, Gotha, 1954.

KÖPPEN, W. Die Wärmezonen der Erde, nach der dauer der heissen, gemässigten und kalten Zeit und nach der Wirkung der Wärme auf die organische Welt betrachtet (The thermal zones of the Earth according to the duration of hot, moderate and cold periods and of the impact of heat on the organic world), Meteorol. Z. n. 1, p. 215-226, 1984. Disponível em: http://koeppen-geiger.vu-wien.ac.at/pdf/Koppen_1884.pdf 
KÖPPEN, W.; GEIGER, R. Klimate der Erde. Gotha: Verlag Justus Perthes. Wallmap 150cm×200cm, 1928.

KRUEGER, C. P. Integração do GPS e da ecobatimetria. Bol. Ciênc. Geod., Curitiba, v. 5, p.55-68, 1999.

KRUPEK, R. A. Análise comparativa entre duas bacias hidrográficas utilizando um protocolo de avaliação rápida da diversidade de habitats. Guarapuava: Ambiência. n. 6, v. 1, p. 147 - 158, 2010.

LACERDA, W. A. Comportamento geomecânico de massas coluviais. In: Anais do III Simpósio de Prática de Engenharia Geotécnica da Região Sul, Geosul '2002. E. Odebrecht et al. (org.). Porto Alegre: Ed. Pallotti. pp. 219-223, 2002.

LAL, R. Soil erosion in the tropics - principles and management. McGraw-Hill, 580p.,1990.

LANA, C. E,; ALVES, J. M. P.; CASTRO, P. T. A. Análise morfométrica da bacia do Rio do Tanque, MG - Brasil. Rem: Rev. Esc. Minas, Ouro Preto, v. 54. n. 2, p. 121-126, $2001 . \quad$ Disponível em: http://www.scielo.br/scielo.php?script=sci_arttext\&pid=S037044672001000200008\&lng=en\&nrm=iso >. access on 16 Mar. 2013. http://dx.doi.org/10.1590/S0370-44672001000200008.

Land \& Water Australia. Case Study 23. River Styles - a generic geomorphic framework to assess catchment character. Acessado em 25/06/2011. Disponível em: http://wa.gov.au/files/products/land-and-water-australiacorporate/ew071245/ew071245-cs-23.pdf

LANZANOVA, M. E. et al. Atributos físicos do solo em sistema de integração lavoura-pecuária sob plantio direto. R. Bras. Ci. Solo, v. 31, p. 1131-1140, 2007.

LANZANOVA, M. E. et al. Efeito do pisoteio bovino na infiltração de água de um argissolo vermelho-amarelo. Acessado em 27/06/2011. Disponível em: http://w3.ufsm.br/ppgcs/congressos/CBCS_RECIFE/MANEJO\%20E\%20CONS ERVA\%C7\%C3O\%20DO\%20SOLO\%20E\%20DA\%20\%C1GUA/pdf/Mastrangel lo\%20Lanzanova.pdf. 
LAWLER, D. M. The measurement of river bank erosion and lateral channel change: A review. Earth Surface Processes and Landforms. v. 18, n. 9, p. 777-821, 1993.

LEGLEITER, C. J.; ROBERTS, D. A.; LAWRENCE, R. L. Spectrally based remote sensing of river bathymetry. Earth Surf. Process. Landforms. v. 34, p. 10391059, 2009.

LEI, T. et al. Run off-on-out method and models for soil infiltrability on hill-slope under rainfall conditions. Science in China: Series D. Earth Sciences. V. 49, n. 2,p. 193- 201, 2006.

LEITE C. B. B. Avaliação do impacto do reservatório de Três Irmãos sobre a superfície potenciométrica do Aquífero Livre na cidade de Pereira Barreto (SP) - uma abordagem numérica e geoestatística. 2005. Tese (Doutorado em Geociências), Instituto de Geociências e Ciências Exatas, Universidade Estadual Paulista, São Paulo, 2005

LEMES, M. J. L. Avaliação de metais e elementos-traço em águas e sedimentos das Bacias Hidrográficas dos Rios Mogi-Guaçu e Pardo, São Paulo. 2001. Dissertação (Mestrado em Tecnologia Nuclear - Aplicações) - Instituto de Pesquisas Energéticas e Nucleares, Universidade de São Paulo, São Paulo, 2001.

LEOPOLD, L. B. \& WOLMAN, M. G. River channel patterns: braided, meandering and straight. USGS Prof. Paper. n. 282-B, p. 39-84, 1957.

LÉVY, S. et al. Erosion and channel change as factors of landslides and valley formation in Champlain Sea Clays: The Chacoura River,; Quebec, Canada, Geomorphology. In Press, Accepted Manuscript doi: 10.1016/j.geomorph.2011.09.014

LIMA, E. R. V. Erosão do solo: fatores condicionantes e modelagem matemática. Revista Cadernos do Logepa. v. 1. n. 1, 2003. Disponível em: http://www.geociencias.ufpb.br/logepa/revistas/pesquisa/ano1_n1/ano1_n1_arti go1.htm

LIN, Q. \& WANG, X. Soil Erosion Prediction Using RUSLE with GIS, A case study in upper Chaobai River basin of China. Geoscience and Remote 
Sensing Symposium, 2006. IGARSS 2006. IEEE International Conference on 2006. v.1, p. 1086-1089, 2006.

LIPORACI, S.R.; ZUQUETTE, L.V. Uma contribuição à geologia do maciço alcalino de Poços de Caldas - MG: mapa do substrato rochoso. In: Geociências. São Paulo: EdUnesp, v. 14. n.1, p. 179-197, 1995.

LOCH, C. \& CORDINI, J. Topografia contemporânea: planimetria. $2^{a}$ ed. Rev. Florianópolis: EdUFSC, 2000.

LÓPEZ, J. L. S. Channel Response to Gravel Mining Activities in Mountain Rivers. Journal of Mountain Science. n.1, v. 3, p. 264-269, 2004.

LORANDI, R. et al. Carta de potencial à erosão laminar da parte superior da bacia do Córrego do Monjolinho (São Carlos, SP). In: Revista Brasileira de Cartografia, n. 53, p. 111-117, 2001.

LOUREIRO, D. D. T. Métodos computacionais e novas tecnologias para o monitoramento do transporte de sedimentos em rios: necessidade de dados e incertezas envolvidas. 2008. Dissertação (Mestrado em Ciências da Engenharia Ambiental), Escola de Engenharia de São Carlos, Universidade de São Paulo, São Carlos, 2008.

LOURES, S. S. A. Ambientes, Uso e Ocupação do Solo e Zoneamento Estratégico para as Sub-bacias dos Rios Jacupiranga e Pariquera-Açu, Vale do Ribeira, SP. 2008. Tese (Doutorado em Engenharia Civil). Universidade Federal de Viçosa, Viçosa 2008.

LUGÃO, C. W.; CALIJURI, L. M.; LOURES, S. S. P. Caracterização da bacia hidrográfica do Rio Jacupiranguinha. In: Subsídios para a sustentabilidade dos recursos hídricos: um estudo de caso em sub-bacias do Baixo Ribeira de Iguape, São Paulo, Brasil. M. C. CALIJURI; A. C. P. MIWA; P. B. FALCO (Org.). São Carlos: EESCUSP, p.17-32, 2009.

MACCARINI, M. (2002). Observações do comportamento mecânico de solos moles na duplicação da Br 101/ SC. In: Anais do III Simpósio de Prática de Engenharia Geotécnica da Região Sul, Geosul '2002. E. Odebrecht et al. (org.). Porto Alegre: Ed. Pallotti. 219-231.

MACHADO, R. E. Simulação de escoamento e de produção de sedimentos em uma microbacia hidrográficautilizando técnicas de modelagem e 
geoprocessamento. 2002. Tese (Doutrado em Agronomia). Escola Superior de Agricultura "Luiz de Queiroz", Universidade de São Paulo, Piracicaba, 2002. MACIEL FILHO, C. L. Introdução à geologia de engenharia. Brasília: CPRM/ UFSM, 1994.

MACKA, Z. Determination of texture of topography from large scale contour maps. Geografski Vestnik. v. 73, n. 2, 53-62, 2001.

MAGRO, T. C. \& TALORA, D. C. Planejamento e manejo de trilhas e impactos na flora. Acessado em: 01/10/2012. Disponível em: http://arquivo.rosana.unesp.br/docentes/fernando/ECO\%20II/MAGRO.\%20Plan ejamento\%20e\%20manejo\%20de\%20trilhas\%20e\%20impactos\%20na\%20flora \%20(CNPMT).pdf

MANABE, S. \& VESEROLD, R. Variations in Water Resources at the Century Scale as a Consequence of Global Warming, Vsemirnaya konf. po izmeneniyu kli_mata. Tez. dokl. World Conference on Climate Change. Abstracts of Papers), Moscow, pp. 14-15, 2003.

MARCHI, L. \& Dalla FONTANA, G. GIS morphometric indicators for the analysis of sediment dynamics in mountain basins. Environ. Geol. v. 48, p. 218-228, 2005.

MARINS, R. V. et al. Distribuição de mercúrio total como indicador de poluição urbana e industrial na costa brasileira. Quim. Nova. v. 27, n. 5, 763-770, 2004.

MARQUES, J. J. G. S. M. et al. Estimativa da erodibilidade a partir de atributos de solos com horizonte b textural no Brasil. R. bras. Ci. Solo, Viçosa, v. 21, p. 457-465, 1997.

MARTIN, S. R.; MCCOOL, S. F.; LUCAS, R. C. Wilderness campsite impacts: Do managers and visitors see them the same? Environmental Management. v. 13, n. 5, p. 623-629, 1989.

MARTINEZ, J.M. et al. Increase in suspended sediment discharge of the Amazon River assessed by monitoring network and satellite data. Catena. 79. 257-264, 2009.

MARTINEZ, J.M. et al. Surface water quality monitoring in large rivers with MODIS data application to the amazon basin. In: Geoscience and Remote Sensing Symposium, 2007. IGARSS 2007. IEEE International. Disponível em: 
http://ieeexplore.ieee.org.ez67.periodicos.capes.gov.br/stamp/stamp.jsp?tp=\&ar number $=4423873$

MARTINS, J. A. Escoamento superficial. In: Hidrologia básica. N. S. Pinto et al. (Org.). São Paulo: Blucher. pp. 36 - 23, 1976a.

MARTINS, J. A. Escoamento superficial. In: Hidrologia básica. N. S. Pinto et al. (Org.). São Paulo: Blucher. pp. 44 - 55, 1976b.

MATULA, M. Principles and types of engineering geological mapping. Report of the omission on engineering geological mapping. Bulletin the International Association of engineering geology. v. 24, 227-234, 1976.

MEADE, R.H., et al. Sediment loads in the Amazon River. Nature, v. 278, p. $161-$ 163, 1979.

MEDINA JÚNIOR, P. B. Avaliação dos impactos da visitação pública no Rio Formoso, Bonito, MS, Brasil: subsídios à gestão ambiental do turismo em áreas naturais. 2007. Tese (Doutrado em Ciências da Engenharia Ambiental) Escola de Engenharia de São Carlos, Universidade de São Paulo, São Carlos, 2007.

MEDRADO, W. A. Caracterização geotécnica de solo da região norte de minas gerais para aplicação em obras rodoviárias. 2009. Dissertação (Mestrado em Engenharia Geotecnia) - Universidade Federal de Ouro Preto, Ouro Preto, 2009.

MEIDA, C. L. et al. Estimativa do potencial erosivo no município de Acopiara, CE, utilizando as ferramentas de SIG. IN: IX Encontro Nacional de Engenharia de Sedimentos - ENES. Brasilia: ABRH, p.14, 2010.

MEIRELES, A. J. A. \& CAMPOS, A. A. Componentes geomorfológicos, funções e serviços ambientais de complexos estuarinos no nordeste do Brasil. Revista da ANPEGE. v. 6. p.89-107, 2010.

MELLO, G.; BUENO, C. R. P.; PEREIRA,G. T. Variabilidade espacial de perdas de solo, do potencial natural e risco de erosão em áreas intensamente cultivadas. R. Bras. Eng. Agríc. Ambiental, v.10, n.2, p.315-322, 2006.

MELOS, A. R.; SATO, A. M. \& COELHO NETTO, A. L. Produção, Estoque e Retenção Hídrica da Serrapilheira em Encosta Sob Plantio de híbridos de 
Eucalyptus urophylla e Eucalyptus grandis: Médio Vale do Rio Paraíba do Sul. Anuário do Instituto de Geociências - UFRJ. v. 33, n. 2, p.66-73, 2010.

MELTON, M. A. An anlysis of the relations among elements of climate, surface properties and geomophology. Technical Report. 11. Dept. Geology, Columbia University, 1957.

MENDES, C. A. R. Erosão superficial em encosta íngreme sob cultivo perene e com pousio no município de Bom Jardim - RJ. 2006. Tese (Doutorado em Engenharia Civil) - Universidade Federal do Rio de Janeiro, Rio de Janeiro, 2006.

MENDES, C. M. \& MENDIONDO, E. M. Histórico da expansão urbana e incidência de inundações: o caso da Bacia do Gregório, São Paulo - SP. Revista Brasileira de Recursos Hídricos. v. 12, n. 1, 17-27, 2007.

MENDICINO, G. Sensitivity Analysis on GIS Procedures for the Estimate of Soil Erosion Risk. Natural Hazards, n. 20, p. 231-253, 1999.

MENESCAL, R. A.; FIGUEIREDO, N. N.; FRANCO, S. R. A problemática das enchentes na região metropolitana de Fortaleza. In: A segurança de barragens e a gestão de recursos hídricos no Brasil. R. A. Mensecal (org.). $2^{\underline{a}}$ Ed. Brasiília: Proágua. p. 235-252, 2005.

MENEZES, M. B. M. Análise da influência do teor de umidade na absorção d'água e sucção dos solos em estudo de erodibilidade. 2010. Dissertação (Mestrado em Geotecnia) - Escola de Engenharia de São Carlos, Universidade de São Paulo, São Carlos, 2010.

MIGUEL, F. R. M.; VIEIRA, S. R.; GREGO, C. R. Variabilidade espacial da infiltração de água em solo sob pastagem em função da intensidade de pisoteio. Pesq. Agropec. Bras., Brasília, v.44, n.11, p.1513-1519, 2009.

MIKHAILOV, V. N. Water and Sediment Runoff at the Amazon River Mouth. Water Resources. v. 37, n. 2, p. 150-163, 2010.

MILAN,D. J.; HERITAGE, G, L.; HETHERINGTON, D. Application of a 3D laser scanner in the assessment of erosion and deposition volumes and channel change in a proglacial river. Earth Surf. Process. Landforms. 32, p.1657-1674, 2007. 
MINISTÉRIO DAS CIDADES. Mapeamento de riscos em encostas e margens de rios. C. S. Carvalho; E. S. Macedo; A. T. Ogura (ord.). Brasília: Ministério das Cidades/ Instituto de Pesquisas Tecnológicas, 2007.

MINOTI, R. T. Abordagens Qualitativa e Quantitativa de Micro-bacias Hidrográficas e Áreas Alagáveis de um Compartimento do Médio MogiSuperior/SP. 2006. Tese (Doutorado em Ciências da Engenharia Ambiental) Escola de Engenharia de São Carlos, Universidade de São Paulo, São Carlos, 2006.

MIRANDA, J. G. Mapeamento geotécnico e estudo da susceptibilidade à erosão na bacia do Ribeirão Ponte de Pedra (MT), escala 1: 100.000. 2005. Tese (Doutorado em Geotecnia) - Escola de Engenharia de São Carlos, Universidade de São Paulo, São Carlos, 2005.

MOLINIER, M. et al. Les regimes hydrologiques de l'Amazone et de ses affluents. In: Chevallier, P., Pouyaud, B. (Eds.), L'hydrologie tropicale: geoscience et outil pour le developpement. AlHS, Paris, pp. 209-222, 1996.

MORAES, A. R. et al. Recursos naturais: solos. Acessado em 09/02//2012.

Disponível em: http://educar.sc.usp.br/ciencias/recursos/solo.html MORAIS, F. Estudo dos pocessos erosivos subsuperficiais na Bacia do Rio Maracujá, MG. 2003. Dissertação (Mestrado em Evolução Crustal e Recursos Naturais) - Universidade Federal de Ouro Preto, Ouro Preto, 2003.

MORAIS, F.; BACELLAR, L. A. P.; SOBREIRA, F. G. Análise da erodibilidade de saprolitos de gnaisse. R. Bras. Ci. Solo, v. 28, p.1055-1062, 2004.

MORELLI, S. et al. Urban planning, flood risk and public policy: The case of the Arno River, Firenze, Italy. Applied Geography. v. 34, p.205-218, 2012. MORENO, M. I. C. \& CARDOSO, E. Utilização do método TWINSPAN na delimitação de formações vegetacionais do cerrado. Caminhos de Geografia. v. 16, n. 16, p.108 - 116, 2005.

MOROZ, I. C.; GOUVEIA, J. M. C.; ROSS, J. L. S. Características geomorfológicas e hidrodinâmicas do Campus USP-Leste, anteriores à sua implantação. Ana Luiza Coelho Netto \& André de Souza Avelar (Org.). In: I Encontro IALE-BR de Degradação Ambiental, Resultantes GeoHidroecológicas e Desafios à Reabilitação Funcional da Paisagem. Rio de 
Janeiro, Vale do Paraíba do Sul, São Paulo. Rio de Janeiro: UFRJ/Geoheco. p. 27-29, 2007.

MOTA, S. Preservação e conservação de recursos hídricos. $2^{\mathrm{a}}$ ed. Rio de Janeiro: ABES, 1995.

MOUTINHO, L. PORSANI, J. L.; PORSANI, M. J. Deconvolucção preditiva de dados GPR adquiridos sobre lâmina d'água: exemplo do Rio Taquari, Pantanal Matogrossense. Revista Brasileira de Geofísica. v. 23, n. 1, p.61-74, 2005.

MOYLES, D. et al. Hydrographic Mapping by Combined Operations Using Bathymetric LIDAR and Multibeam Echosounder in Alaska. Acessado em 01/08/2011. Disponível em: http://www.thsoa.org/hy05/04_5.pdf

MYERS, N. Deforestation Rates in Tropical Forests and their Climatic Implications. Friends of the Earth Report, London, 1989.

NAHON, I. M.; KISHI, R.T.; FERNANDES, C. V. S. Desenvolvimento de um Sistema de Apoio à Análise de Outorga de Lançamento de Efluentes Estudo de Caso: Bacia do Alto Iguaçu. Revista Brasileira de Recursos Hídricos. v.14, n. 2, p. 47-58, 2009.

NANSON, G.C. \& YOUNG, R.W. Downstream reduction of rural channel size with contrasting urban effects in small coastal streams of southeastern Australia. Journal of Hydrology. v. 52, p. 239-255, 1981.

NASCIMENTO, F. R. Categorização de usos múltiplos dos recursos hídricos e problemas ambientais. Anpege. v. 7, n. 1, p.81-97, 2011.

NASCIMENTO, P. S. R. \& GARCIA, G. J. Compartimentação fisiográfica para análise ambiental do potencial erosivo a partir das propriedades da rede de drenagem. Eng. Agríc., Jaboticabal, v. 25, n.1, p.231-241, 2005.

NEGREIROS, A. B. \& COELHO NETTO, A. L. Reabilitação funcional de clareira de deslizamento em encosta íngreme no domínio da floresta atlântica, Rio De Janeiro (RJ). Revista Brasileira de Geomorfologia. v. 10, n. 1, p.85-93, 2009.

NEVES, F. F. Análise prospectiva das áreas de risco à erosão na microbacia hidrográfica do Rio Bonito (Descalvado - SP), potencial poluidoras por dejeto de grajas. 2005. Dissertação (Mestrado em Ciências da Engenharia 
Ambiental). - Escola de Engenharia de São Carlos, Universidade de São Paulo, São Carlos, 2005.

NICHOLS, G. Rivers: the fluvial environment. In: Sedimentology and stratigraphy.

Great Britain: Blackwell Science, p. 111-127, 1999.

NOGAMI, J. S. \& VILLIBOR, D. F. Pavimentação de baixo custo com solos lateríticos. São Paulo: Ed. Villibor, p. 213, 1995.

OLIVEIRA et al. Mercúrio total em solos de manguezais da baixada santista e ilha do cardoso, Estado de São Paulo. Quim. Nova. v. 30, n. 3, 519-524, 2007.

OLLIER, C. Tectonics and landforms. In: C. Ollier (Ed.) Series Geomorphology texts. New York: Clayton, p.161-180, 1981.

OMETTO, J.C. Bioclimatologia vegetal. São Paulo: CERES, 1981.

ONYANDO, J. O.; KISOYAN, P.; CHEMELI, M. C. Estimation of Potential Soil Erosion for River Perkerra Catchment in Kenya. Water Resources Management. v. 19, p. 133-143, 2005.

OZDEMIR, H. \& BIRD, D. Evaluation of morphometric parameters of drainage networks derived from topographic maps and DEM in point of floods. Environ Geol. v. 56, p.1405-1415, 2009.

PALHARES J, C.P. et al. Medição da Vazão em Rios pelo Método do Flutuador. Concórdia: EMBRAPA. Comunicado Técnico, n. 455. 4p., 2007

PANKAJ, A. \& KUMAR, J. GIS-based Morphometric Analysis of Five Major Subwatersheds of Song River, Dehradun District, Uttarakhand with Special Reference to Landslide Incidences. J. Indian Soc. Remote Sens. v. 37, p.157-166, 2009.

PARK, S.S.; LEE, Y. S. A water quality modeling study of the Nakdong River, Korea. Ecological Modellig. 152, 65-75p., 2002. Acesso em: 10 de janeiro de 2006.

Disponível

em:

http://www.sciencedirect.com/science?_ob=ArticleURLe_udi=B6VBS44VXOSX-

3e_user $=686451$ e_coverDate $=06 \% 2 \mathrm{~F} 15 \% 2 \mathrm{~F} 2002 \mathrm{e}$-rdoc=1e_fmt=e_orig=sear che_sort=deview $=c e \_a c c t=C 000037559$ e_version $=1$ e_urlVersion $=0$ e_userid $=6$ 86451emd5=3b8debf10fa9ca2bfba95759489b74d1. 
PARZANESE, G. A. C. Gênese e desenvolvimento das voçorocas em solos originados de rochas granitóides da região de Cachoeira do Campo, Minas Gerais. 1991. Dissertação (Mestrado) - Universidade Federal de Viçosa, Viçosa, 1991.

PATTON, P. C. \& BAKER, V. R. Morphometry and floods in small drainage basins subject to diverse hydrogeomorphic control. Water Resources Research. v. 12, n. 5, p.941-952, 1976.

PATTON, P. C. Drainage basin morphometry and floods. In: Baker VR, Kochel RC, Patton PC (eds) Flood geomorphology. Wiley, USA, pp 51-65, 1988.

PAULA E SILVA, F. et al. Sucessão sedimentar do Grupo Bauru na região de Pirapozinho (SP). Geociências. 25. p. 17-26, 2006.

PAULA E SILVA, F. Geologia de subsuperfície e hidroestratigrafia do Grupo Bauru no Estado de São Paulo. 2003. 166p. Tese (Doutorado em Geociências) - Instrituto de Geociências e Ciências Exatas, Universidade Estadual Paulista, 2003.

PAULA E SILVA, F.; Chang, H. K.; CAetano-ChanG, M. R. Perfís de referência do Grupo Bauru (K) no Estado de São Paulo. Geociências. 22. p. 2132, 2003.

PEDRO, F. G. \& LORANDI, R. Potencial natural de erosão na área periurbana de São Carlos-SP. In: Revista Brasileira de Cartografia. n. 56/01, p. 28 - 33, 2004.

PEEL, M. C.; FINLAYSON, B. L.; MCMAHON, T. A. Updated world map of the Köppen-Geiger climate classification. Hydrol. Earth Syst. Sci., n. 11, pp.1633-1644, 2007.

PEJON, O. J. \& SILVEIRA, L. L. L. Index properties to predict erodibility of tropical soil. Bull. Eng. Geol. Environ. v. 66, p. 225-236, 2007.

PEJON, O. J. Mapeamento geotécnico regional da folha Piracicaba - SP escala 1:10.000: estudo de aspectos metodológicos, de caracterização e de apresentação de atributos. 1992. Tese (Doutorado em Geotecnia) - Escola de Engenharia de São Carlos, Universidade de São Paulo, São Carlos, 2005. 
PELLETIER, G. J.; CHAPRA, S. C.; TAO, H. QUAL2Kw - a framework for modeling water quality in streams and rivers using a genetic algorithm for calibration. Environmental Modelling \& Software. n. 21: pp.419-425, 2006.

PEREIRA, A. R., ANGELOCCI, L. R., SENTELHAS, P. C. Agrometeorologia: Fundamentos e Aplicações Práticas. Livraria e Editora Agropecuária LTDA, RS, pp. 478, 2002.

PIMENTEL, D. et al. Environmental and Economic Costs of Soil Erosion and Conservation Benefits. SCIENCE. n. 267. p. 24, 1995.

PINESE JÚNIOR, J. F.; CRUZ, L. M. \& RODRIGUES, S. C. Monitoramento de erosão laminar em diferentes usos da terra, Uberlândia - MG. In: Sociedade \& Natureza. Uberlândia: EDUFU. 20. 2: pp.5-18, 2008.

PINTO, C. S. Curso básico de macânica dos solos em 16 aulas. $3^{\text {a }}$ ed. São Paulo: Oficina de textos, 2006.

PIRES NETO, A. G. As abordagens sintético histórica e analítico dinâmica, uma proposição metodológica para a geomorfologia. 1991. Tese (doutorado em Geografia Física) - Faculdade de Filosofia, Letras e Ciências Humanas da Universidade de São Paulo, São Paulo, 1991.

PONS, N. A. D. Levantamento e diagnóstico geológico-geotécnico de áreas degradadas na cidade de São Carlos - SP, com auxílio de geoprocessamento. 2006. Tese (Doutorado em Geotecnía) - Escola de Engenharia de São Carlos, Universidade de São Paulo, São Carlos, 2006.

PRANDI, E. C. \& VILAR, O. M. Erosão dos solos. In: Solos do interior de São Paulo. São Carlos: ABMS, v. 1, 1993.

Programa das Nações Unidas para o Meio Ambiente. Geo Brasil. Recursos hídricos: componente da série de relatórios sobre o Estado e perspectivas do meio ambiente no Brasil. Brasília: MMA/ANA, 2007.

QUINTAS, M. C. L. Um estudo de compensação isostática para a bacia do Paraná. In: Bol. Ciênc. Geod., sec. Artigos, Curitiba, v. 8, n. 2, p.93-108, 2002. QUINTON, J. N. et al. The impact of agricultural soil erosion on biogeochemical cycling. Nature Geoscience. n. 3, p. $311-314,2010$.

RAIMUNDO, H. A.; SANTOS, G. T.; DIAS, R. D. Aspéctos geotécnicos do contato granito/diabásio associados à instabilidade de encostas em Florianópolis 
- SC. In: Anais do III Simpósio de Prática de Engenharia Geotécnica da Região Sul, Geosul '2002. E. Odebrecht et al. (org.). Porto Alegre: Ed. Pallotti. p. 251 263, 2002.

RAPOSO, A. A. et al. Reflexos de pressões antrópicas e da erosão acelerada sobre a dınâmıca fluvıal da bacıa do Rıbeırão Sardınha - Quadrı́átero Ferrífero / MG. 2010. 15p. Acessado em: 14/07/2010. Disponível em: www.geo.ufv.br/simposio/simposio/trabalhos/trabalhos_completos/eixo3009.pdf.

$\mathrm{RAUCH}, \mathrm{W}$. et al. River water quality modelling: I. State of the art. 38: n. 11. p. 237-244, 1998.

REDDY G.P.O.; MAJI A.K.; GAJBHIYE, K.S. Drainage morphometry and its influence on landform characteristics in basaltic terrain, central India - a remote sensing and GIS approach. Int. J. Appl. Observ. Geoinf. v. 6, p.1-16, 2004.

REGO, J. J. V. Erosão superficial em taludes de corte em solo residual de gnaisse. 1978. Dissertação (Mestrado em Engenharia Civil). Universidade Federal do Rio de Janeiro, Rio de Janeiro, 1978.

RICKERT, D. A. \& HINES, W. G. River quality assessment implications of a prototype project. Results of the Willamette River, Oregon, have national implications for resource management programs. Science. v. 200, n. 4346, p.1113 - 1118, 1978.

RIGO, M. L. et al. Resistência ao cisalhamento residual de alguns solos da Formação Serra Geral (RS). In: Solos e rochas: revista latino-americana de geotecnia. São Paulo: ABMS/ABGE. v. 27, n. 3, p.273-286, 2004.

RIGO, M. L. et al. Resistência ao cisalhamento residual de alguns solos da Formação Serra Geral (RS). In: Solos e rochas: revista latino-americana de geotecnia. São Paulo: ABMS/ABGE. v. 27, n. 3, p.273-286, 2004.

RITTER, D. F.; KOCHEL, R. C.; MILLER, J. R. Process geomorphology. $3^{\text {rd }}$ ed. Dubuque: William C. Brown, 1985.

RODRIGUES, J. E. Estudo de fenômenos acelerados: boçorocas. 1982. Tese de Tese (Doutorado em Geotecnia) - Escola de Engenharia de São Carlos, Universidade Federal de São Paulo, São Carlos, 1982. 
RODRIGUES, R. A. Modelação das deformações por colapso devido à ascensão do lençol frático. 2007. Tese (Doutorado em Geotecnia) - Escola de Engenharia de São Carlos, Universidade Federal de São Paulo, São Carlos, 2007.

RODRIGUES, R. R. \& GANDOLFI, S. Conceitos, tendências e ações para a recuperação de florestas ciliares. In: Matas ciliares: conservação e recuperação. R. R. RODRIGUES \& H. F. LEITE FILHO (Org.). $2^{\text {a }}$ ed. São Paulo: EdUSP/ FAPESP, p. 15-25, 2001.

ROLIM, G. S. et al. Classificação climática de Köppen e de Thornthwaite e sua aplicabilidade na determinação de zonas agroclimáticas para o Estado de São Paulo. Bragantia, Campinas, v. 66, n. 4, p.711-720, 2007.

ROMANA, M. New adjustment ratings for application of Bieniawski classification to slope. Int. Sym. on the role of rock mechanics. Zacatecas, p. 49-53, 1985.

ROSGEN, R. L. A classification of natural Rivers. Catena. n. 22, p.169-199, 1994.

ROSS, J. L. S. Análise empírica da fragilidade dos ambientes naturais antropizados. Revista do Departamento de Geografia. n. 8, p.63-74, 1994.

ROSS, J. L. S. Geomorfologia aplicada aos EIAs-Rimas. In: Geomorfologia e meio ambiente. A. J. T. Guerra \& S. B. Cunha (org.). Rio de Janeiro: Bertrand Brasil. p. 291-336, 1996.

ROSS, J. L. S. O registro cartográfico dos fatos geomórficos e a questão da taxonomia do relevo. Revista do Departamento de Geografia. n. 8, p.17-29, 1992.

ROSS, J. L. S. Relevo brasileiro: uma nova proposta de classificação. Revista do Departamento de Geografia. n. 4, p.25-39, 1985.

RUBEL, F. \& KOTTEK, M. Observed and projected climate shifts 1901-2100 depicted by world maps of the Köppen-Geiger climate classification. Meteorologische Zeitschrift, v. 19, n. 2, p. 135-141, 2010.

SANCHEZ, P. A. et al. Amazon Basin Soils: Management for Continuous Crop Production. Science. n. 216. p. 821-827, 1982. 
SANTANNA et al. Estudo preliminar da velocidade e direção dos ventos, em Cuiabá, MT, Brasil. Revista Brasileira de Agrometeorologia, v.16, n. 2, p.175180, 2008.

SANTI, O.G.R. et al. Relações entre estado de compactação, aeração e textura de solos do Rio Grande do Sul. Acessado em 27/06/2011. Disponível em: http://w3.ufsm.br/ppgcs/congressos/CBCS_RECIFE/FISICA/pdf/Olavo\%20Gabr iel\%20R\%20Santi.pdf

SANTOS, L. L. Modelos hidráulicos-hidrológicos: conceitos e aplicações. Revista Brasileira de Geografia Física. n.2. v. 3, p.01-19, 2009.

SANTOS, M. L.; FERNANDEZ, O. V. Q.; STEVAUX, J. C. Aspectos morfogenéticos das baras de canal do Rio Paraná, trecho de Porto Rico, PR. Boletim de Geografia - UEM. n. 10. v. 1, p.11- 24, 1992.

SARMA, J.N.; BORAH, D.; GOSWAMI, U. Change of river channel and bank erosion of the Burhı Dihıng River (Assam), assessed usıng remote sensıng data and GIS. Journal of the Indian Society of Remote Sensing. n. 35, v. 1, p.93-100, 2007.

SBCS. Manual de descrição e coleta de solo em campo. $2^{\mathrm{a}}$ Ed. Campinas: SBCS, 1982.

SCHLUTER, U. Zur Geschichte der Ingenieurbiologie. Landschaft: Stadt. n. 16, p. 2-9, 1984.

SCHMIDT, J. The impact of rainfall on sediment transport by sheetflow. In: Erosion, transport and deposition processes: theories and models. Germany: CATENA VERLAG. n. 19, p.9-17, 1991.

SCHNEIDER et al. Revisão estratigráfica da bacia do Paraná. In: Anais do Congresso Brasileiro de Geologia, 28, Porto Alegre, v.1, p. 41-65, 1974.

SCHNEIDER, D. D.; BERNAL, T. A.; RISSE, F. Application of the Rapid Habitat Diversity Evaluation Protocol and concentration of phosphorous and nitrogen of Barrinha Stream. I Simpósio Internacional de Ecologia. São Carlos: UFSCAR, 2011.

SCHUMM, S. A. Sinuosity of alluvial rivers on the great plains. Geol. Soc. America Bull. n. 74. V. 9, p.1089-1100, 1963. 
SCOTTISH ENVIRONMENTAL PROTECTION AGENCY. River habitat survey in Britain and Ireland. Field survey guidance manual. 2003. 74p.

Secretaria de Meio Ambiente de São Paulo. Qualidade das águas interiores no Estado de São Paulo. Série relatórios: APÊNDICE B. São Paulo: SEMA, 2008. $27 p$.

SEOK, S. S. \& LEE, Y. S. A water quality modeling study of the Nakdong River, Korea. Ecological Modelling. n. 152, p.65-75, 2002.

SHANAHAN, P. et al. River water quality modelling: II. Problems of the art. Water Science and Technology. n. 38, v. 11, p.245-252, 1998.

SHERMAN L. K. The relation of hydrographs of runoff to size and character of drainage basin. Trans Am Geophys Union. n. 13, p.332-339, 1932.

SHIKLOMANOV, I.A. Water Resources as a Challenge of the Twenty First Century. Tenth IMO Lecture. WMO, 959, 2003.

SILVA, A. F. Mapeamento geotécnico e análise dos processos erosivos na bacia do córrego Tuncum, São Pedro-SP, escala 1:10.000. 2003. $131 \mathrm{f}$. Dissertação (Mestrado em Geotecnia) - Escola de Engenharia de São Carlos, Universidade de São Paulo, São Carlos, 2003.

SILVA, A. M.; SCHULZ, H. E.; CAMARGO, P. B. Erosão e hidrossedimentologia em bacias hidrográficas. São Carlos: RiMa, 2003. 140p.

SILVA, F. F.; LOUREIRO, H. A. S.; SILVEIRA, T. S. Diagnóstico dos deslizamentos na cidade do Rio de Janeiro a partir das chuvas de abril de 2010: estudo de caso do Morro dos Prazeres. Revista de Geografia (Recife). n. 27, v. 3, p.180-192, 2010.

SILVA, F. P. Geologia de subsuperfície e hidroestratigrafia do Grupo Bauru no estado de São Paulo. 2003. Tese (Doutorado em Geociências) - . Rio Claro: Universidade Estadual Paulista, Instituto de Geociências e Ciências Exatas.

SILVA, J. E. B. \& GUERRA, A. J. T. Análise das propriedades dos solos das subbacias do Rio Tindiba e do Córrego do Catonho, Rio de Janeiro, com fins à identificação de áreas com predisposição à erosão. 2001. In: VII Simpósio Nacional de Controle de Erosão. Acessado em 08/02/2011. Disponível em: http://www.labogef.iesa.ufg.br/links/simposio_erosao/articles/T017.pdf 
SILVA, M. A. F. Podologia em bovinos: conceitos basilares. Vila Real: Universidade de Trás-Os-Montes e Alto Douro, 2009.

SILVINO, A. N. O. Avaliação e modelagem da qualidade da água da bacia do rio Coxipó, no município de Cuiabá - MT. 2008. 145p. Dissertação (Mestrado em Física e Meio Ambiente) - Universidade Federal de Mato Grosso, Cuiabá, 2008. SIMON, A. L. H. A Dinâmica do Uso da Terra e sua Interferência na Morfohidrografia da Bacia do Arroio Santa Bárbara-Pelotas (RS). 2007.185 f. Dissertação (Mestrado em. Geografia) - Universidade Estadual Paulista Júlio de Mesquita Filho, Rio Claro-SP, 2007.

SINGH, B. \& GOEL, R. K. Rock mass classification: a practical approach in civil engineering. The Nederlands: ELSEVIER, 1999. 262p.

SOARES et al. Ensaio de caracterização estratigráficado Cretácio no Estado de São Paulo: Grupo Bauru. In: Revista Brasileira de Geociências, São Paulo SP. p.177-185, 1980.

SOARES, J. M. D. ; PINHEIRO, R. J. B.; TAVARES, S. P. Notas de aula de mecânica dos solos. Santa Maria: UFSM/ Departamento de Transportes, 2006.

SOBREIRA, F. G. Processos erosivos acelerados (voçorocas): o exemplo de Cachoeira do Campo, Ouro Preto, MG. Solos e rochas. n. 23, v. 3, p. 217233, 2000.

Sociedade Brasileira de Ciência do Solo. Manual de descrição e coleta de solo no campo. $2^{\mathrm{a}}$ ed. Campinas: SBCS/ Serviço Nacional de Levantamento e Conservação de Solos, 1982.

SONNEMAKER, J. P. Meteorologia. 23를 ed. São Paulo: ASA, 2002.

SOUSA PINTO, N. L. Águas subterrâneas. In: Hidrologia básica. N. S. Pinto et al. (Org.). São Paulo: Blucher. pp. 67 - 91, 1976.

SOUSA, A. R., SILVA, A. B., RESENDE, M. Influência da pressão exercida por pisoteio de animais na compactação do solo do vale do Pajeú, em Pernambuco. In: REUNIÃO BRASILEIRA DE MANEJO E CONSERVAÇÃO DO SOLO DA ÁGUA, 12, 1988, Fortaleza. Anais... Fortaleza: SBCS. pp.256$257,1998$. 
SOUSA, L. M. O. Fracturação de afloramentos graníticos - implicações na extracção de rocha ornamental. In: Solos e rochas: revista latino-americana de geotecnia. São Paulo: ABMS/ABGE. 27. 3: pp.273-286, 2004.

SOUZA PINTO, N. I. \& HOLTZ, A. C. T. Medições de vazão. In: Hidrologia básica. N. S. Pinto et al. (Org.). São Paulo: Blucher. pp.182-204, 1976.

SOUZA, G. F. et al. Vulnerabılıdade natural da paısagem em função das áreas de plantıo de cana-de-açúcar. Geografia (Londrina). n. 19, v. 3, p. 51-65, 2010. Disponível em: http://www.uel.br/revistas/uel/index.php/geografia/

SOUZA, L. A. P. Revisão crítica da aplicação dos métodos geofísicos na investigação de áreas submersas rasas. 2006. Tese (Doutorado em Oceanografia) - Universidade de São Paulo, São Paulo 2006.

SOUZA, M. L.; GASPARETTO, N. V. L.; NAKASHIMA, P. Diagnóstico geoambiental da bacia do Córrego Tenente em Mariluz, Paraná, Brasil. Revista Brasileira de Geociências. São Paulo: SBG. n. 38, v. 2, p.379-391, 2008.

STAL, C. et al. Accuracy assessment of a LiDAR digital terrain model by using RTK GPS and total station. EARSeL eProceedings n. 10, v. 1. 2011. 8p.

STANCATI, G.; NOGUEIRA, J.B. \& MONJEVILAR, O. Ensaios de laboratório em Mecânica dos Solos. São Carlos. EESC/USP, 1981. 208p.

STANISZEWSKI, R. et al. Assessment of sources of uncertainty in macrophyte surveys and the consequences for river classification. Hydrobiologia. $n$. 566, p. 235-246, 2006.

STRAHLER, A. N. Hypsometric (area-altitude) analysis of an erosional topography. Geol. Soc. Am. Bull. n. 38, p.1117-1142, 1952.

STRAHLER, A.N. Quantitative geomorphology of drainage basins and channel networks. In: Handbook of applied hydrology. Chow VT (ed). New York, pp 440-474, 1964.

STUDART, T. M. C. Escoamento Superficial. 2003. Disponível em: http://www.deha.ufc.br/ticiana/hidrologia/apostila.htm .

SUÁREZ, J. M. Sítio fossilífero de Piraporazinho, SP. Extraordinário depósito de quelônios do Cretácio. SIGEP 32. In: Sítios geológicos e paleontológicos do Brasil. p. 49-54, 2002. 
SUMMERFIELD M. A. Neotectonics and landform genesis. Progress in Physical Geography, n. 11, v. 3, p. 384-397, 1987.

SUMMERFIELD M. A. Tectonics geomorphology. Progress in Physical Geography. London. n. 15, v. 2, p. 193-205, 1991.

SUZUKI, L. E. A. S. et al. Grau de compactação e sua influência nas propriedades físicas do solo e rendimento da soja. 2011. Acessado em 27/06/2011. Disponível em: http://w3.ufsm.br/ppgcs/congressos/CBCS_RECIFE/FISICA/pdf/Luis\%20Eduar do\%20Akiyoshi\%20Sanches\%20Suzuki.pdf

TALORA, D. C. Efeitos do pisoteio experimental sobre a vegetação de dunas do Parque Estadual da Serra do Mar, Picinguaba, Ubatuba, SP. 2007. Tese (Doutorado em Recursos Florestais) - Escola Superior de Agricultura Luiz de Queiroz, Universidade de São Paulo, Piracicaba, 2007.

TERZAGHI, K. Rock defects and load on tunnel supports. Introduction to tunnelling with steal support. Ohio: Commercial Sheering \& Stamping Co., 1946.

TEWARI, P. A Study on Soil Erosion in Pasighat Town (Arunachal Pradesh) India. Natural Hazards. n. 32, p.257-275, 2004.

THOMA, D. P.; GUPTA, S. C.; BAUER, M. E. Quantifying River Bank Erosion with Scanning Laser Altimetry. In: International Archives of Photogrammetry and Remote Sensing. pp.169-174, 2001.

THOMSON, J. R.; TAYLOR, M. P.; BRIERLEY, G. J. Are river styles ecologically meaningful? a test of the ecological significance of a geomorphic river characterization scheme. Aquatic Conserv. Mar. Freshw. Ecosyst. n. 14, p. 25-48, 2004.

THORNBURY, W.D. Principles of Geomorphology. $2^{\text {nd }}$ ed. New York: Wiley, 1969. 594pp.

THORNE, P. D. \& HANES, D. M. A review of acoustic measurement of smallscale sediment processes. Continental Shelf Research. n. 22, p.603-632, 2002.

THORNTHWAITE, C.W. An approach towards a rational classification of climate. Geographical Review, London, v. 38, p. 55-94, 1948. 
TOCKNER, K. et al. Ecology of braided rivers. In: Swiss Federal Institute for Forest, Snow and Landscape Research WSL. 36p. Acessado em 23/09/2011. Disponível em: http://www.wsl.ch/land/products/rhonethur/publikationen/Tockner_et_al_Braided_rivers.pdf

TOMASINI, B. A. et al. Infiltração de água no solo em áreas cultivadas com cana-de--açúcar sob diferentes sistemas de colheita e modelos de ajustes de equações de infiltração. Eng. Agríc., Jaboticabal, v.30, n.6, pp.1060-1070, 2010.

TONELLO, K. C. et al. Morfometria da bacia hidrográfica da Cachoeira das Pombas, Guanhães - MG. R. Árvore, Viçosa-MG. n. 30, v. 5, p,849-857, 2006. TRINDADE, M. Nutrientes em sedimentos da represa do Lobo (Brotas Itirapina, SP). 1980. Dissertação (Mestrado em Ecologia e Recursos Naturais) - Universidade Federal de São Carlos São Carlos, São Carlos, 1980.

TROEH, F.R. Landform equations fitted to contour maps. American Journal of Science. n. 263, p. 616-627, 1965.

TUCCI, C. E. M. Enchentes urbanas. In: Drenagem Urbana. Ed. da Universidade, ABRH, 1995.

TUCCI, C. E. M. Plano diretor de drenagem urbana: princípios e concepção. Revista Brasileira de Recursos Hídricos. n. 2, v. 2, p.5-12, 1997.

TUCKER, G. E. Drainage basin sensitivity to tectonic and climatic forcing: implications of a stochastic model for the role of entrainment and erosion thresholds. Earth Surf. Process. Landforms. n. 29, p. 185-205, 2004.

TUNDISI, J. G. Impáctos ecológicos da construção de represas: aspectos específicos e problemas de manejo. IN: Limniologia e manejo $d$ e represas. Série Monografias em limnologia. J. G. Tundisi (org.). v. 1. São Carlos: EESC/USP/CRHEA/ Academia de Ciências. pp.1-7, 1988.

VALDIVIESO, F. O. Metodología para la evaluación del riesgo de erosión hídrica en zonas áridas y su aplicación en el manejo y proteccion de proyectos hidráulicos. REDLACH. v. 1, n. 1, p. 27-32, 2004.

Van OOST, K et al. The Impact of Agricultural Soil Erosion on the Global Carbon Cycle. Science. v. 318, n. 5850, p. 626-629, 2007. 
VENDRAMINI, D. Aspectos hidrogeoquímicos de uma microbacia reflorestada com Eucaliptus grandis no município de Angatuba - São Paulo. $195 f$. 2009. Dissertação (Mestrado em Química na Agricultura e Ambiente) - Escola Superior de Agricultura "Luiz de Queiroz", Universidade de São Paulo, Piracicaba, 2009.

VERRIOS, S.; ZYGOURI, V.; KIKKALAS, S. Morphotectonic analysis in the Eliki fault zone (Gulf of Corinth, Greece). Bulletin of the geological society of Greece. n. 36, p. 1706-1715, 2004.

VERSTAPPEN, H.T. Applied geomorphology. ITC, Enschede, 1983.

VICENTE, M. L.; NAVAS, A.; MACHÍN, J. Geomorphic mapping in endorheic catchments in the Spanish Pyrenees: An integrated GIS analysis of karstic features. Geomorphology. n. 111. 38-47, 2009.

VIEIRA, L. S. Manual da ciência do solo: com ênfase aos solos tropicais. São Paulo: Ed. Agronômica Ceres, 1988.

VIEIRA, M. N. F. et al. Levantamento e conservação do solo. Belém: FCAP, 1996.

VILAR, O. M. Formulação de um modelo matemático para erosão dos solos pela chuva. 1987. 196f. Tese (Doutorado). São Carlos: EESC/ USP,

WARN, S. River long profiles \& valley cross profiles. 2001. Geo Factsheet. № 25. Acessado em: 29/07/2011. Disponível em: http://www.curriculum-press.co.uk/

Wolman, M. G. A cycle of sedimentation and erosion in urban river channels. Geografiska Annaler. Series A. Physical Geography, pp. 385-395, 1967.

WRIGHT, J. F. Development of RIVPACS in the UK and the value of the underlying data-base. Limnética. v. 0, n. 1, p. 15-31, 1994.

WRIGHT, J.F.; FURSE, M.T.; MOSS, D. River classification using invertebrates: RIVPACS applications. Aquatic Conserv: Mar. Freshw. Ecosyst. n. 8, p. 617$631,1998$.

WYRICK, J. R. \& KLINGEMAN, P. C. Proposed fluvial island classification scheme and its use for river restoration. River Research and Applications. 2010. p.12.

XAVIER, A. L. \& TEIXEIRA, D. A. Diagnóstico das nascentes da sub-bacia hidrográfica do Rio São João em Itaúna, MG. IN: Anais do VIII Congresso de 
Ecologia do Brasil, 23 a 28 de Setembro de 2007, Caxambu - MG. Acessado em 29/09/2011. Disponível em: http://www.sebecologia.org.br/viiiceb/pdf/1597.pdf.

YANG, S. et al. A review of soil erodibility in water and wind erosion research. Journal of Geographical Sciences. v. 15, n. 2, p. 167-176, 2005.

YOSHIZANE, H. P. Notas de aula de mecânica dos solos. Campinas: UNICAMP/CESET, 2005. pp.46.

YUAN, L. L. Predictive models for bioassessment of large and great rivers. In: Great Rivers Reference Condition Workshop. Cincinnati: The U.S. Environmental Protection Agency and The Council of State Governments, 2006. $17 \mathrm{p}$.

YUE-QING, X.; JIAN, P.; IAO-MEI, S. Assessment of soil erosion using RUSLE and GIS: a case study of the Maotiao River watershed, Guizhou Province, China. Environ. Geol. n. 56, p. 1643-1652, 2009.

ZACHAR, D. Developments in soil science 10: Soil erosion. Bratislava: VEDA/ Elsevier, 1982.

ZAINE, J. ED. Mapeamento geológico-geotécnico por meio do método do detalhamento progressivo: ensaio de aplicação na área urbana do município de Rio Claro (SP). 2000. 149f. Tese (Doutorado em Geociências e Meio Ambiente) - Universidade Estadual Paulista Júlio de Mesquita Filho, 2000.

ZANCOPÉ, M.H. C. Estudo dos padrões de canal luvial do Rio Mogi Guaçu/SP. 2004. 90f. Dissertação (Mestrado em Geografia) - Instituto de Geociências e Ciências Exatas, Universidade Estadual Paulista Júlio de Mesquita Filho. Rio Claro, 2004.

ZANINI, H. L. H. T. Caracterização limnológica e microbiológica do córrego rico que abastece Jaboticabal (SP). 2009. 75f. Tese (Doutorado em Ciências Agrárias e Veterinárias) - Universidade Estadual Paulista Júlio de Mesquita Filho Jaboticabal, 2009.

ZAÚ, A. S.; COELHO NETTO, A. L.; OLIVEIRA, R. R. Cobertura florestal: degradação, resultantes ecológicas e efeitos de borda no Parque Nacional da Tijuca, Rio de Janeiro/RJ. In: I ENCONTRO IALE-BR. Degradação 
Ambiental, Resultantes Geo-ldroecológicas e Desafios à Reabilitação Funcional da Paisagem. pp. 53-65, 2007.

ZOCCAL, J. C. Soluções cadernos de estudos em conservação do solo e água.

Presidente Prudente: CODASP, 2007.

ZUFFO, A. C. Seleção e aplicação de métodos multicriteriais ao planejamento ambiental de recursos hídricos. 1998. Tese (Doutorado em Hidráulica e Saneamento) - Escola de Engenharia de São Carlos, Universidade de São Paulo, São Carlos, 1998.

ZUQUETTE, L. V. \& PALMA, J. B. Avaliação da condutividade hidráulica em área de recarga do aqüífero Botucatu. R. Esc. Minas. 59. 1: p. 81-87, 2006.

ZUQUETTE, L. V. Importância do mapeamento geotécnico no uso e ocupação do meio físico: fundamentos e guia para elaboração. 2v. 1993. Tese (Livre Docência) - Escola de Engenharia de São Carlos, Universidade de São Paulo, São Carlos, 1993.

ZUQUETTE, L. V.; CARVALHO, J. A. R. \& YAMANOUTH, G. R. B. Feições erosivas na bacia do córrego do Espraiado, São Pedro (SP), seus tipos e evolução entre 1972-2002. In: Revista Brasileira de Geociências. v. 37, n. 2, p. 414-425, 2007. 


\section{Apêndice 1}

Dados das Seções Ecobatimétricas 


\section{Apêndice 1}

\section{Seção ecobatimétrica 1 -1'}

\% ADP Data File: VOC1101131100.adp

$\%$ Start Date + Time: 02/01/2011 01:56:43

$\%$ All Track Calculations use: GPS data

$\%$ All Flow Velocities Relative to: GPS

$\%$ Metric Units

$\%$

\%Profile Time Distance DMG DistEast DistNorth GPS Latitude GPS Longitude Depth1 Depth2 Depth3 AvDepth EsDepth uVess DirVess uFlow DirFlow StdDev DQI \# Valid Q Q Cumul
$\%$
$(\mathrm{m}) \quad(\mathrm{m}) \quad(\mathrm{m})$
(m) (deg) (deg)
$(\mathrm{m}) \quad(\mathrm{m}) \quad(\mathrm{m})$
$(\mathrm{m}) \quad(\mathrm{m}) \quad(\mathrm{m}) \quad(\mathrm{m} / \mathrm{s}) \quad(\mathrm{deg}) \quad(\mathrm{m} / \mathrm{s}) \quad(\mathrm{deg})$

$(\mathrm{m} / \mathrm{s}) \quad$ Cells $\quad\left(\mathrm{m}^{\wedge} 3 / \mathrm{s}\right) \quad\left(\mathrm{m}^{\wedge} 3 / \mathrm{s}\right)$

$\%$

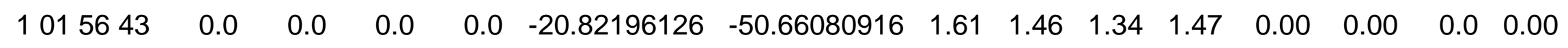
$\begin{array}{llllll}0.0 & 0.00100 .0 & 1 & 0.00 & 0.0 & 0.00\end{array}$

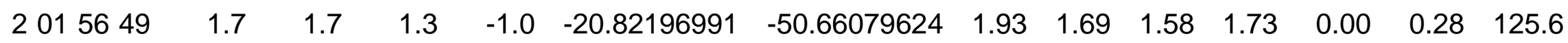

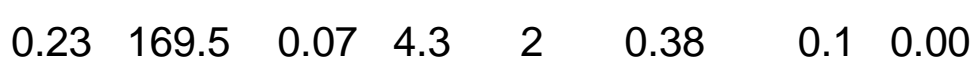




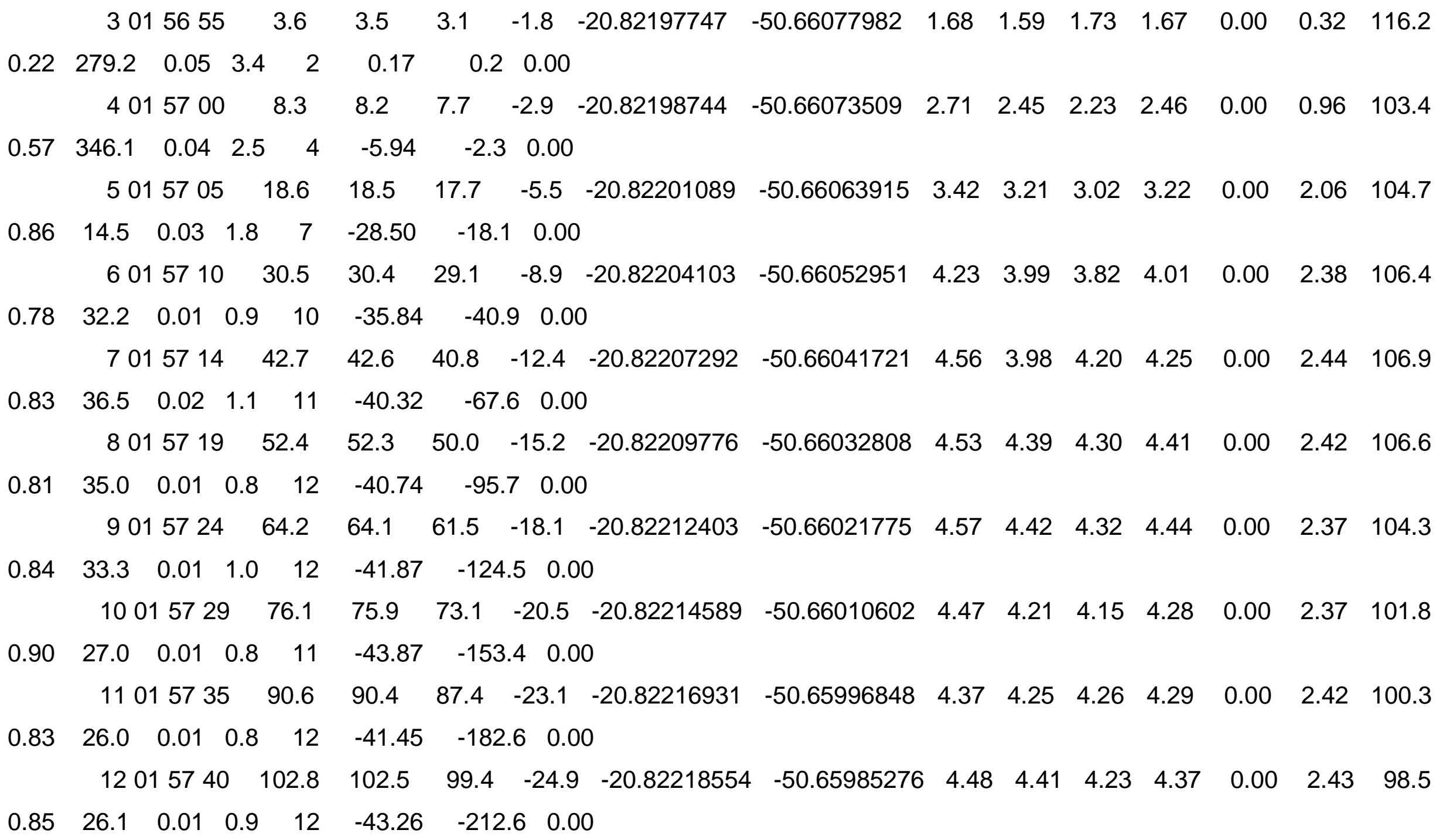




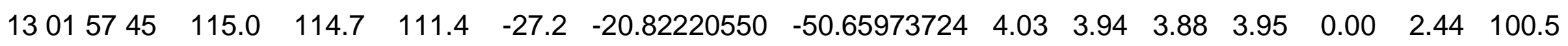

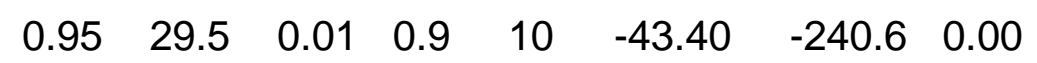

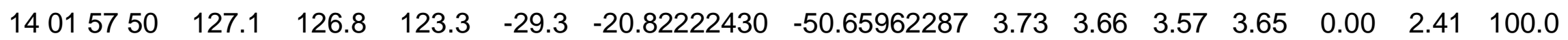

$\begin{array}{llllllll}0.89 & 26.1 & 0.02 & 1.4 & 9 & -37.72 & -264.2 & 0.00\end{array}$

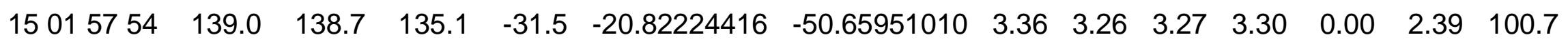

$\begin{array}{llllllll}0.90 & 17.9 & 0.01 & 1.0 & 8 & -35.18 & -285.7 & 0.00\end{array}$

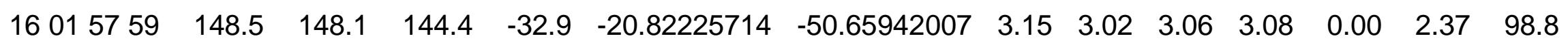

$\begin{array}{llllllll}0.69 & 24.9 & 0.02 & 1.6 & 7 & -24.08 & -299.5 & 0.00\end{array}$

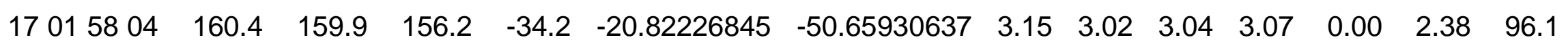

$\begin{array}{llllllll}0.83 & 20.0 & 0.02 & 1.3 & 7 & -29.51 & -316.5 & 0.00\end{array}$

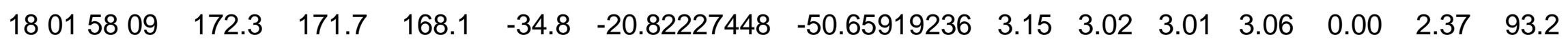

$\begin{array}{llllllll}0.83 & 11.1 & 0.03 & 1.5 & 7 & -29.69 & -333.6 & 0.00\end{array}$

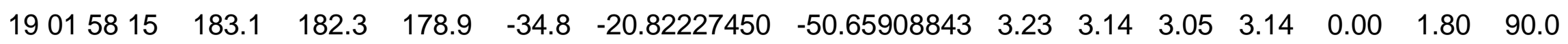

$\begin{array}{llllllll}0.60 & 35.2 & 0.02 & 1.4 & 7 & -13.92 & -341.5 & 0.00\end{array}$

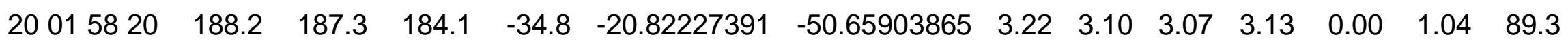

$\begin{array}{llllllll}0.39 & 38.3 & 0.02 & 1.7 & 7 & -4.97 & -344.3 & 0.00\end{array}$

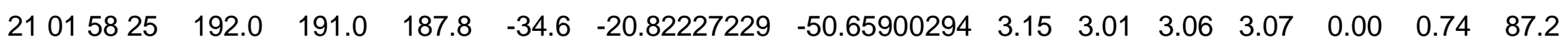

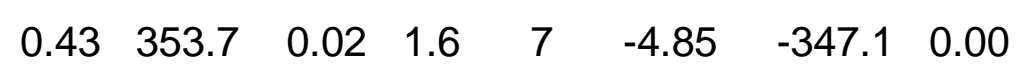




\section{Seção ecobatimétrica 2 - 2'}

Data File: VOC1101141203.adp

\% Start Date + Time: 03/01/2011 02:59:17

$\%$ All Track Calculations use: GPS data

$\%$ All Flow Velocities Relative to: GPS

$\%$ Metric Units

$\%$

\%Profile Time Distance DMG DistEast DistNorth GPS Latitude GPS Longitude Depth1 Depth2 Depth3 AvDepth EsDepth uVess DirVess uFlow DirFlow StdDev DQI \# Valid Q Q Cumul

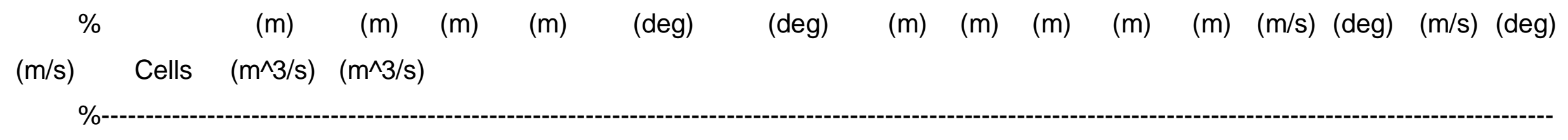

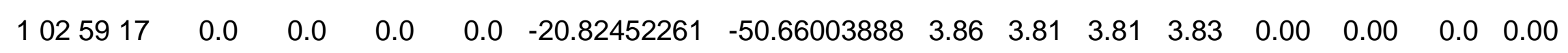

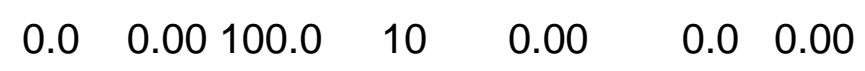

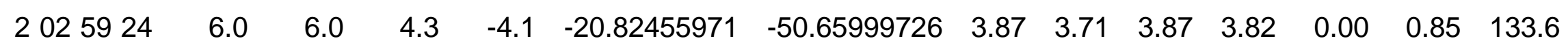

$\begin{array}{llllllll}0.37 & 57.4 & 0.02 & 1.5 & 9 & -5.85 & -3.5 & 0.00\end{array}$

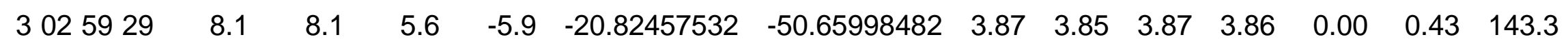

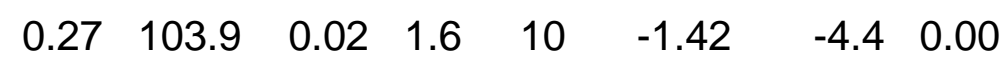




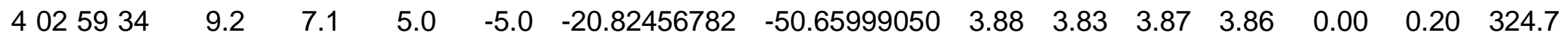

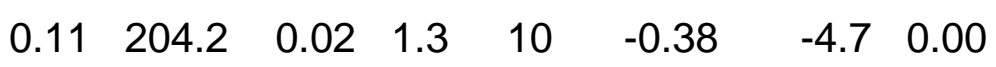

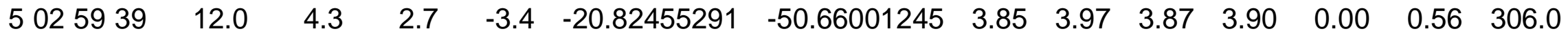

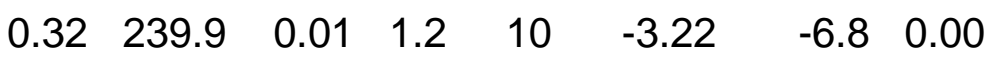

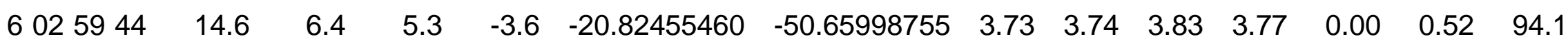

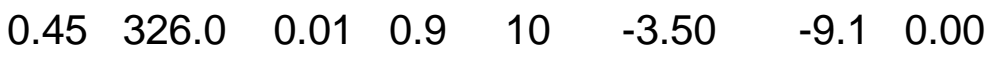

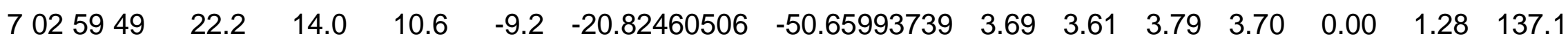

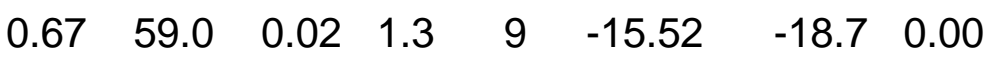

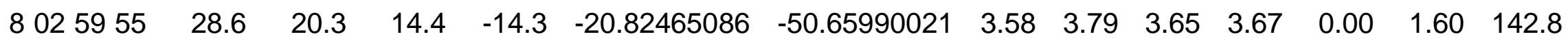

$\begin{array}{llllllll}0.58 & 61.4 & 0.02 & 1.4 & 9 & -16.78 & -29.1 & 0.00\end{array}$

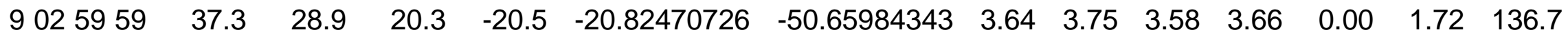

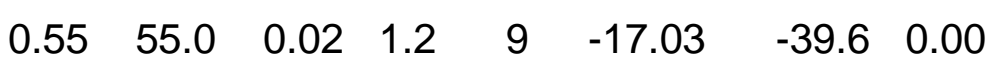

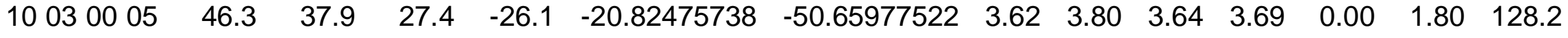

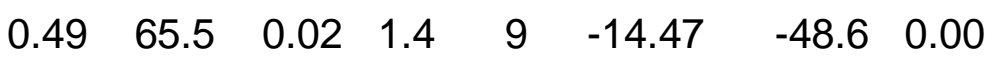

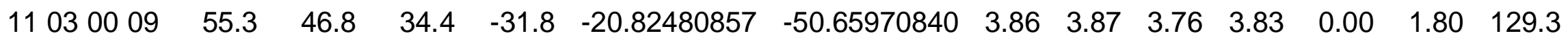

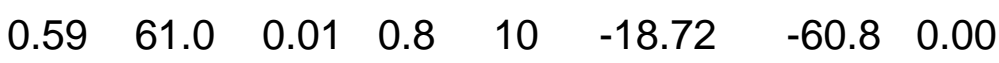

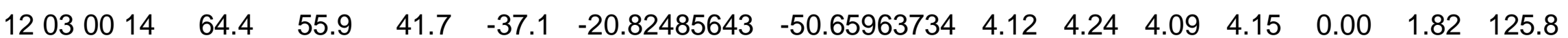

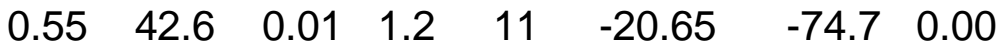

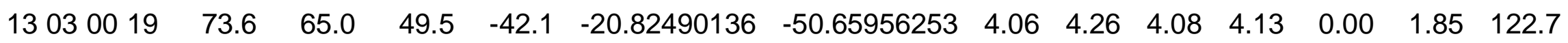

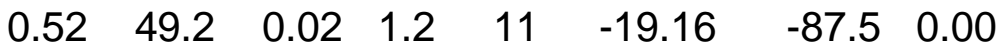




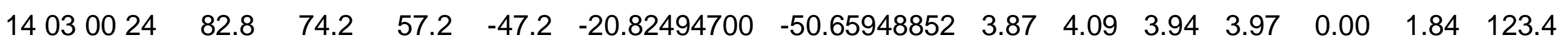
$\begin{array}{llllllll}0.61 & 37.5 & 0.01 & 1.3 & 10 & -22.20 & -101.7 & 0.00\end{array}$

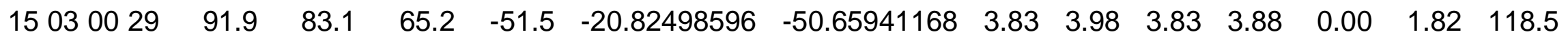

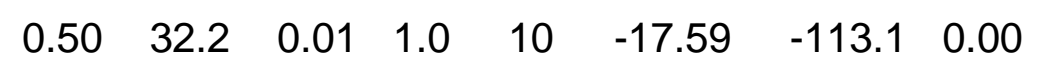

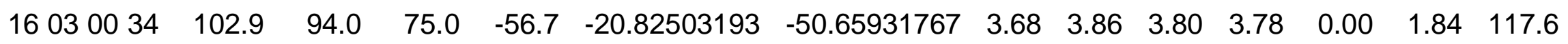

$\begin{array}{llllllll}0.70 & 42.7 & 0.02 & 1.3 & 9 & -23.41 & -127.3 & 0.00\end{array}$

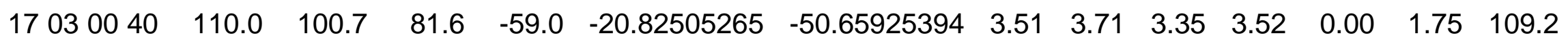

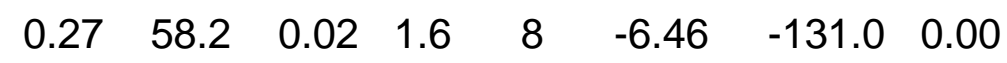

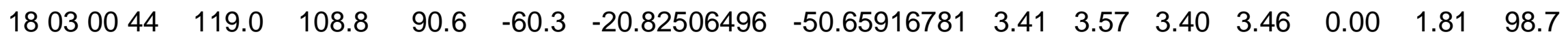

$\begin{array}{llllllll}0.48 & 41.4 & 0.02 & 1.4 & 8 & -12.53 & -138.4 & 0.00\end{array}$

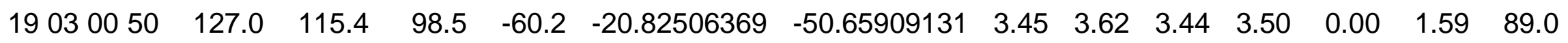

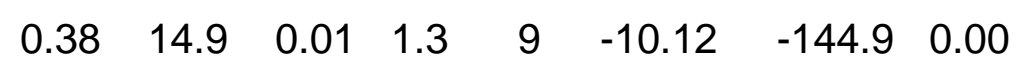

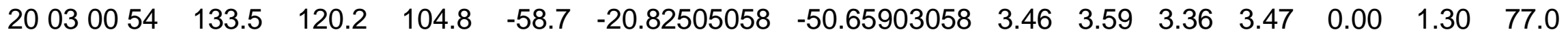

$\begin{array}{llllllll}0.23 & 24.1 & 0.03 & 1.7 & 8 & -4.17 & -147.3 & 0.00\end{array}$

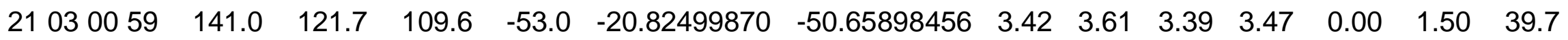

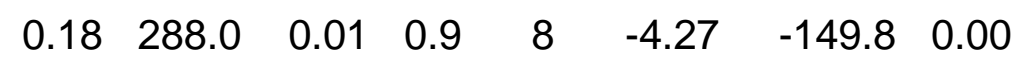

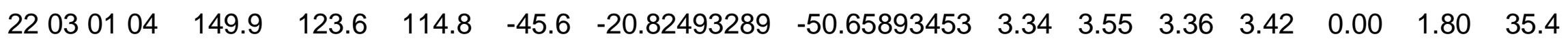

$\begin{array}{llllllll}0.41 & 317.1 & 0.02 & 1.4 & 8 & -12.31 & -157.1 & 0.00\end{array}$

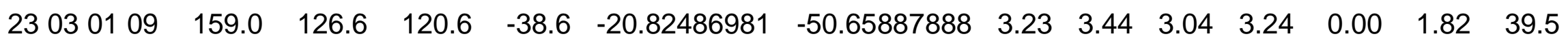

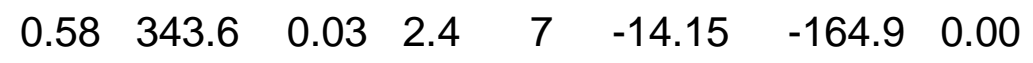




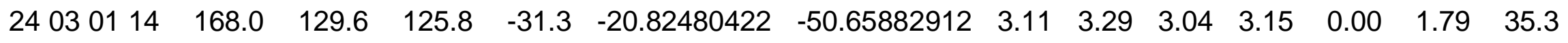

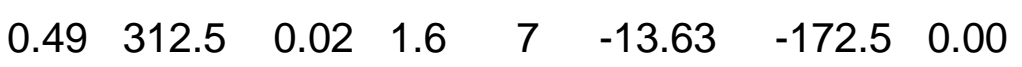

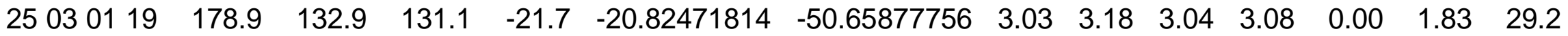

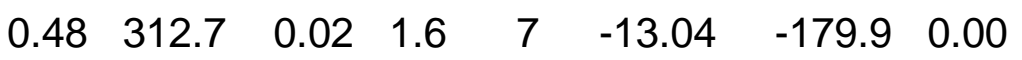

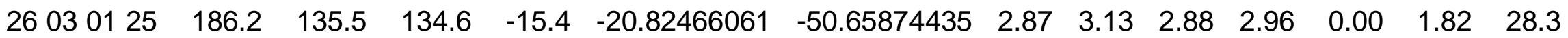

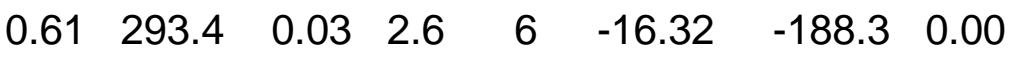

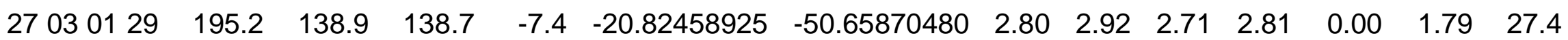

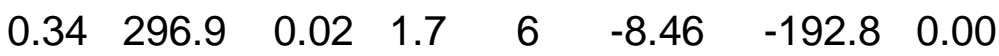

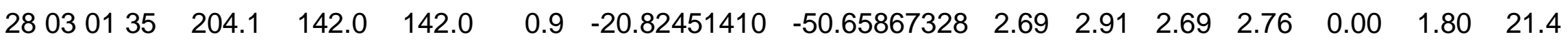

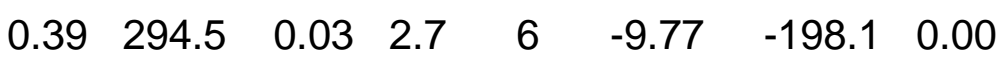

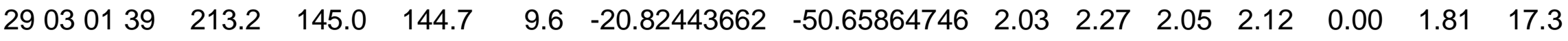

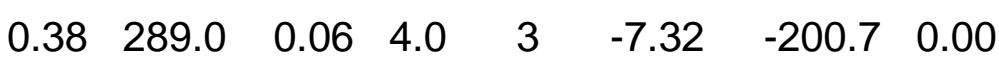

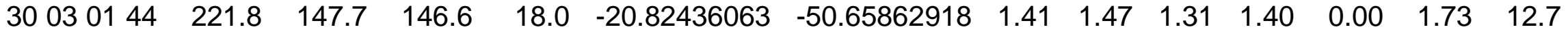

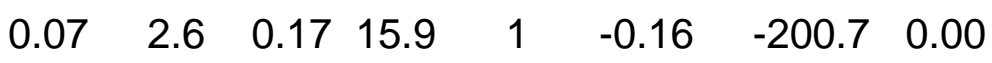

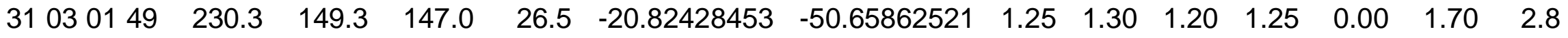

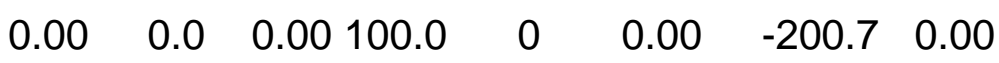

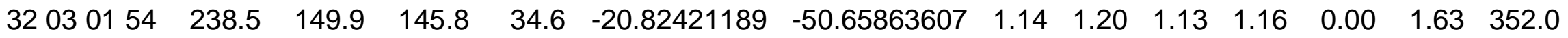

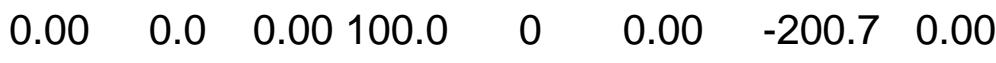

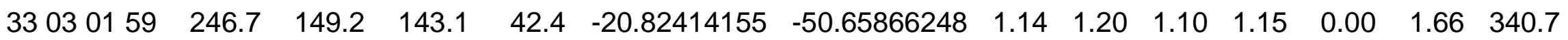

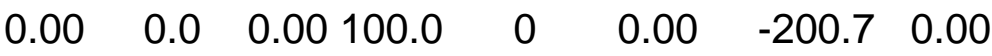




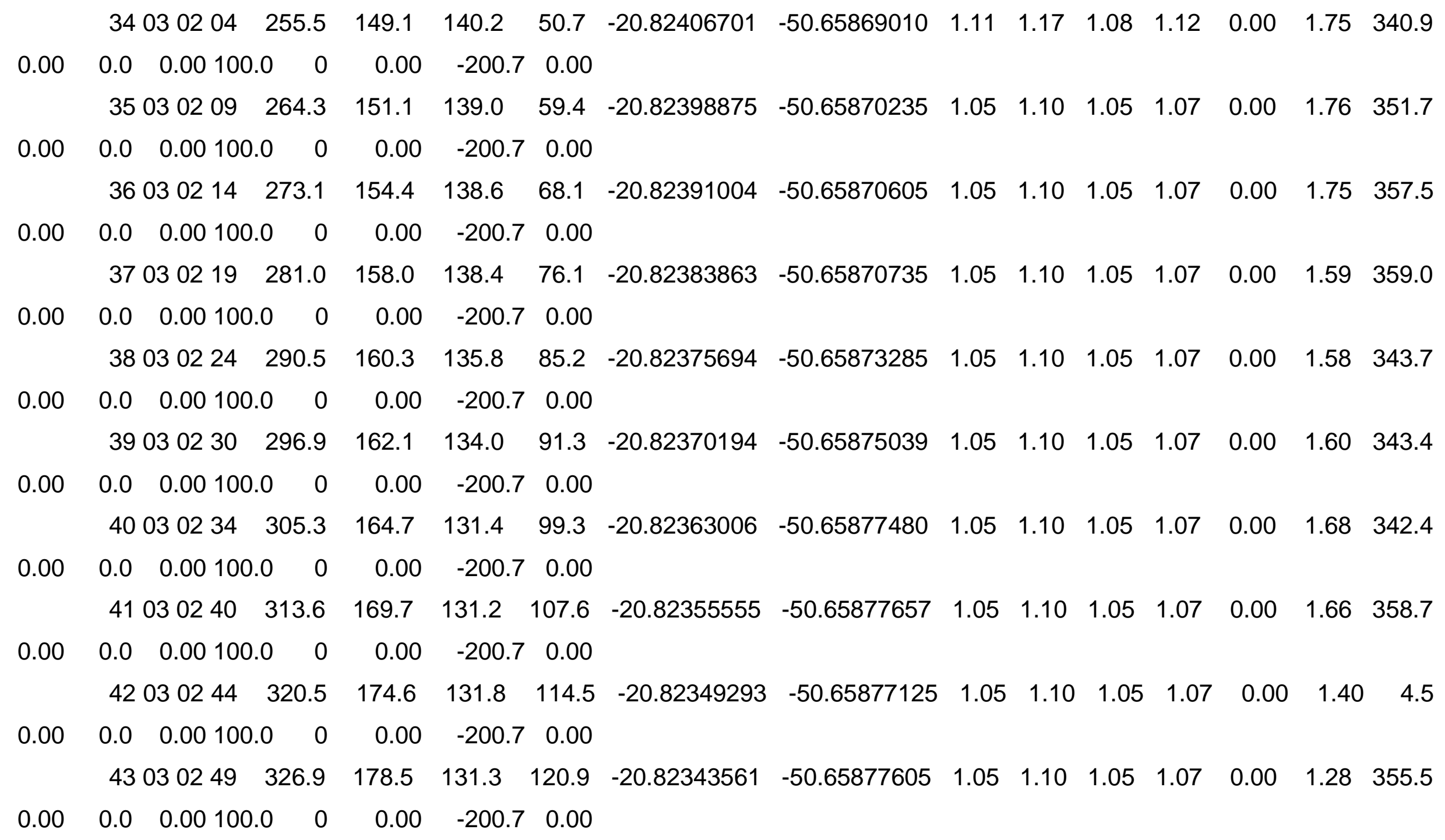




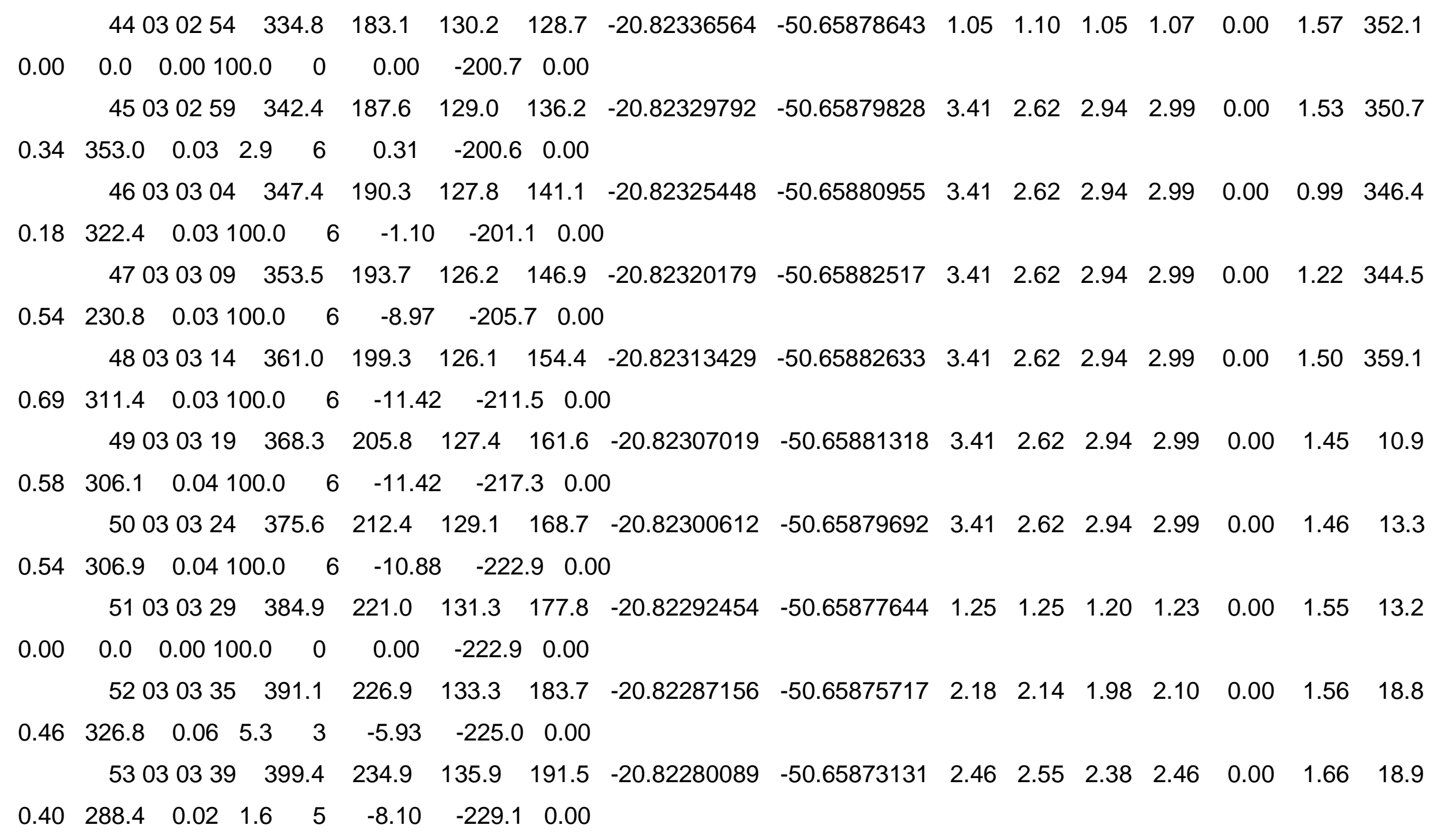




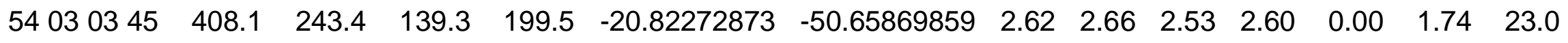

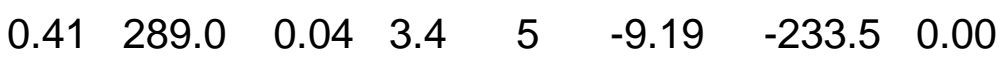

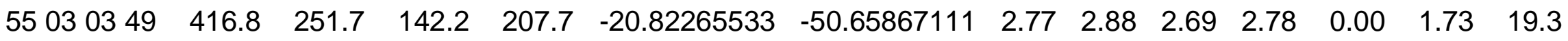

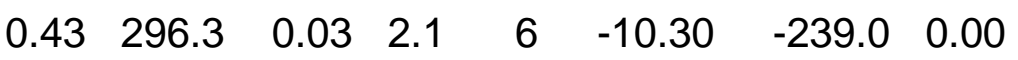

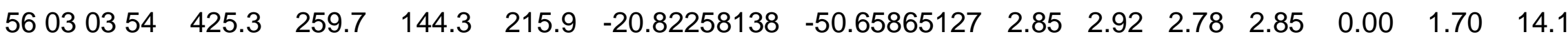

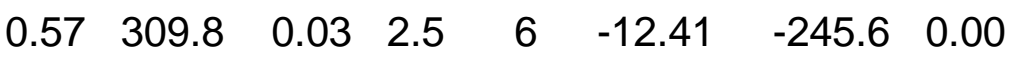

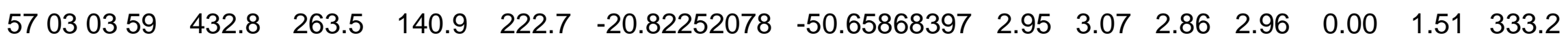

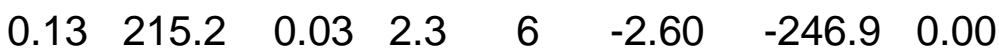

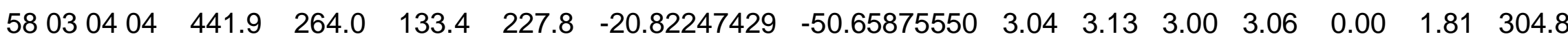

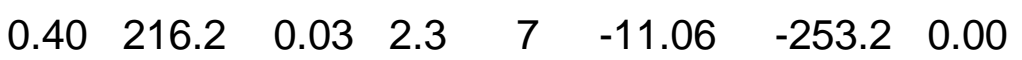

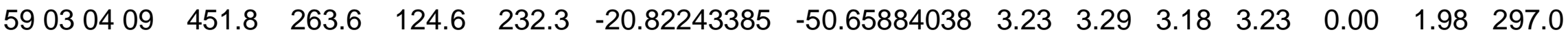

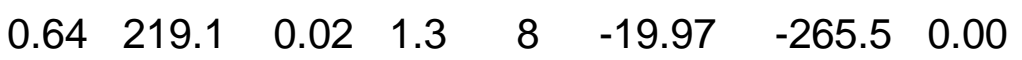

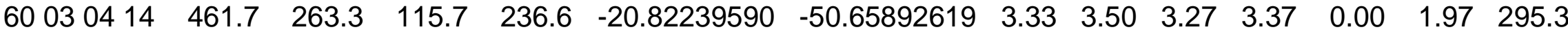

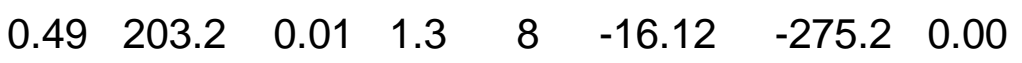

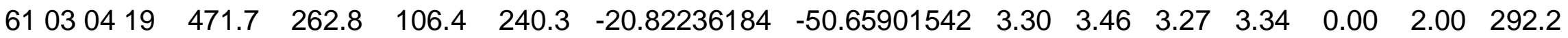

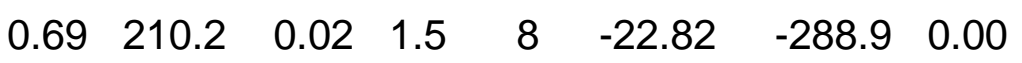

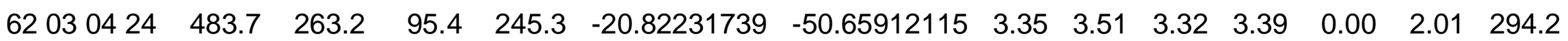

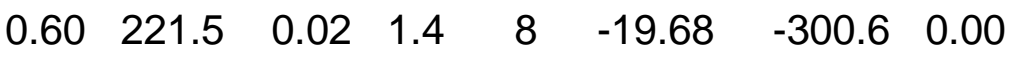

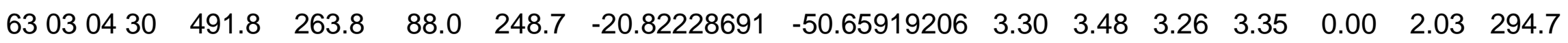

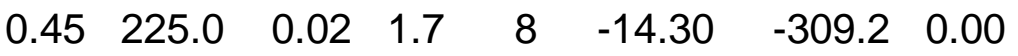




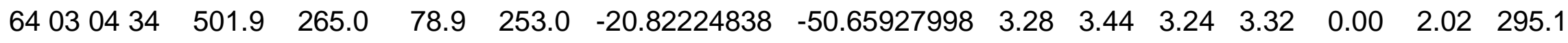

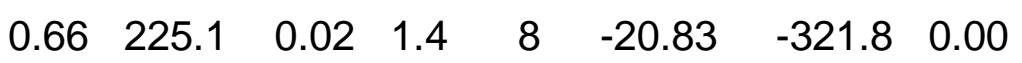

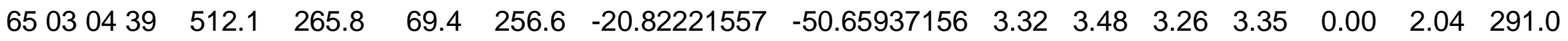

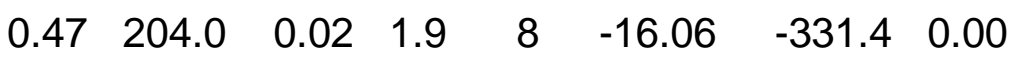

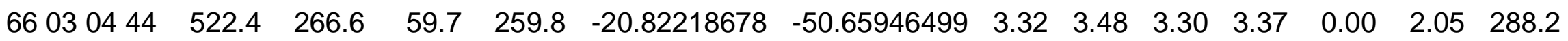

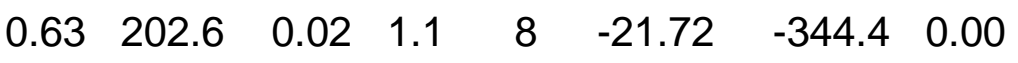

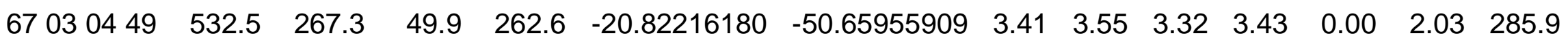

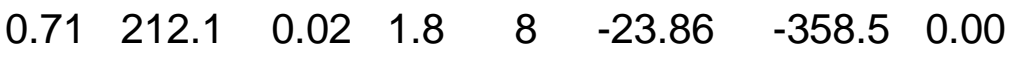

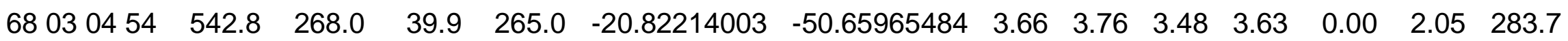

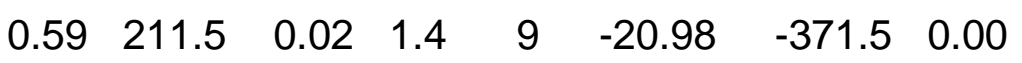

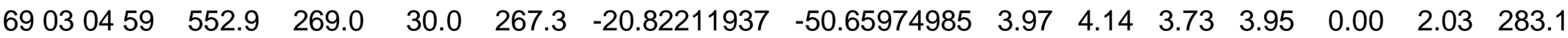

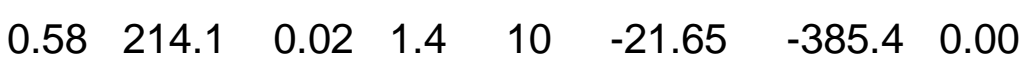

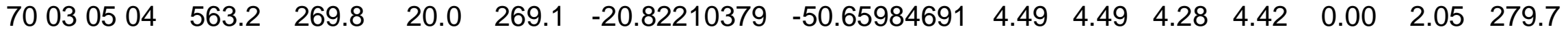

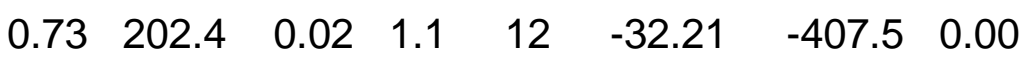

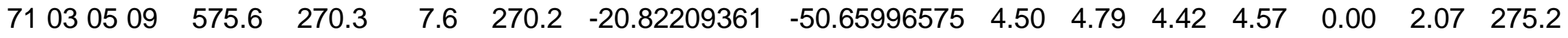

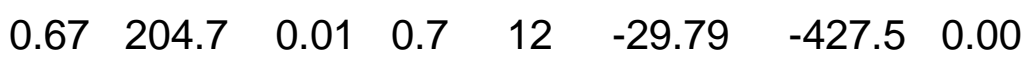

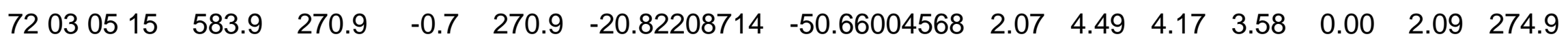

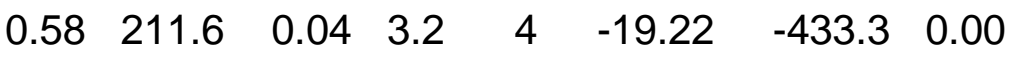

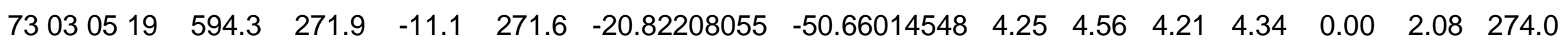

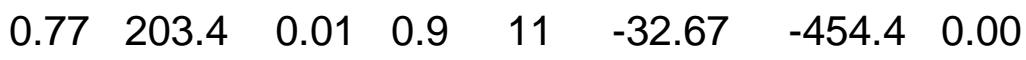




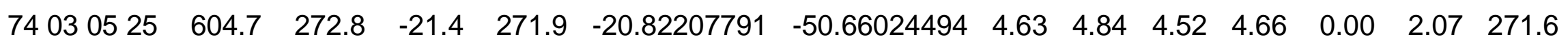

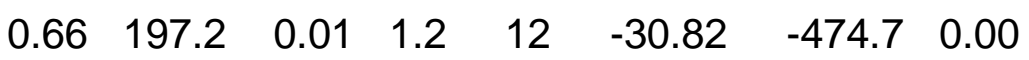

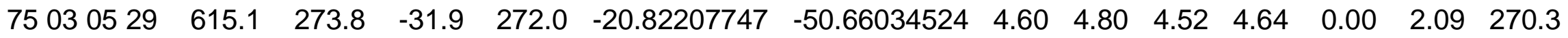

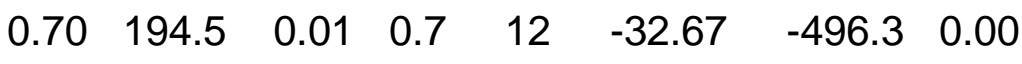

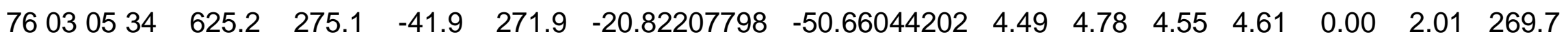

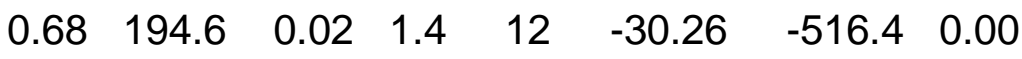

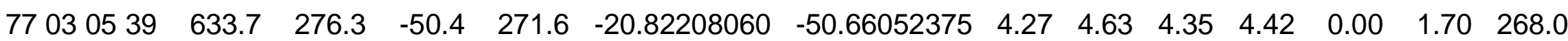

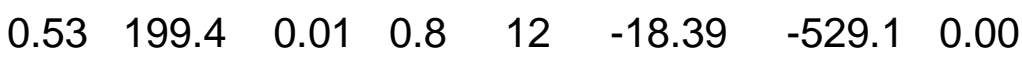

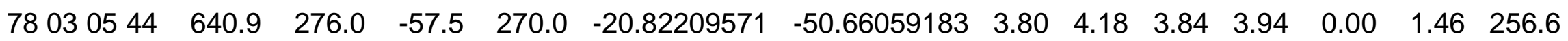

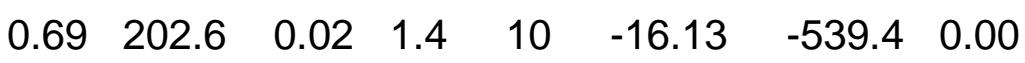

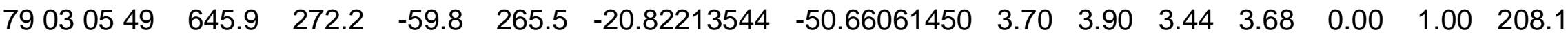

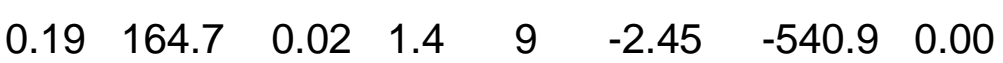

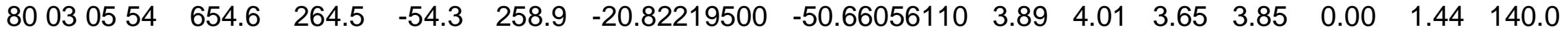

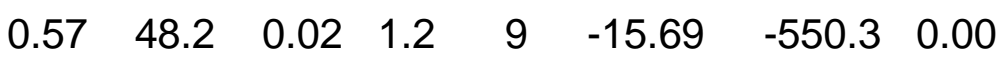

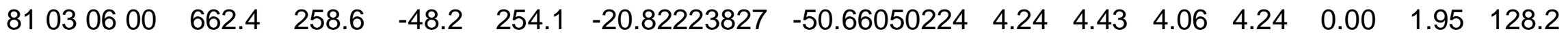

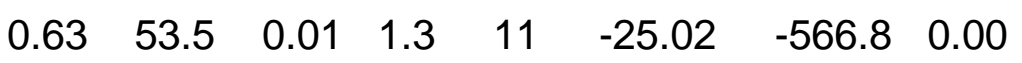

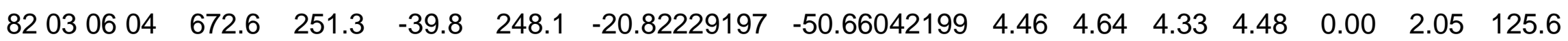

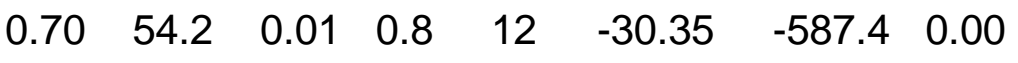

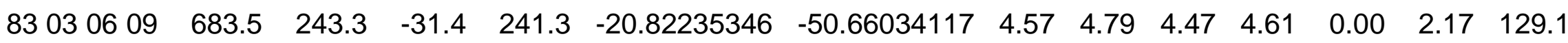

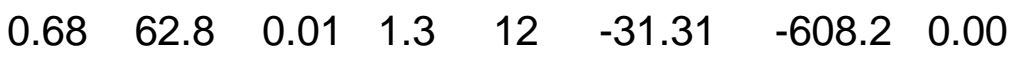




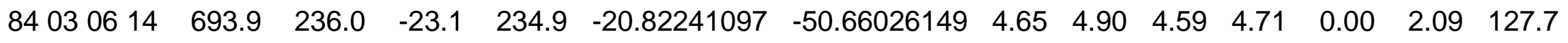

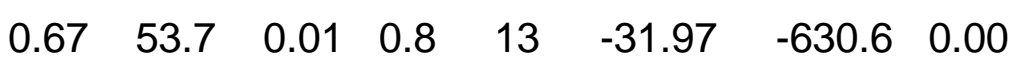

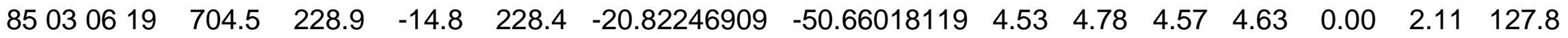

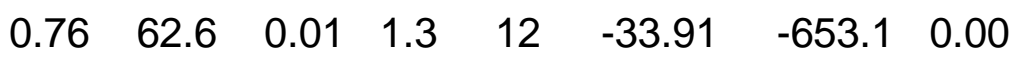

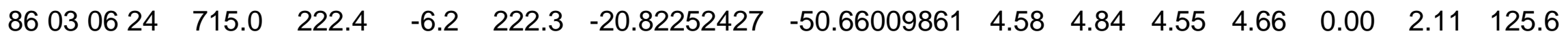

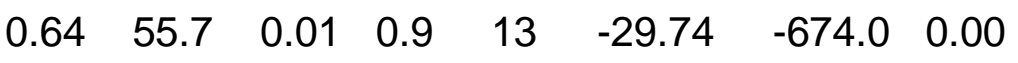

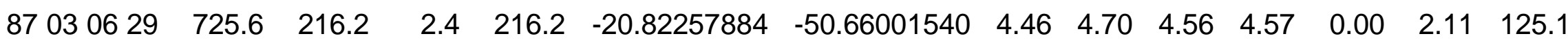

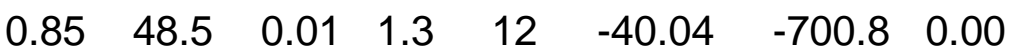

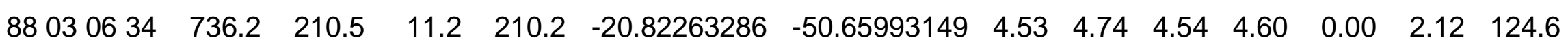

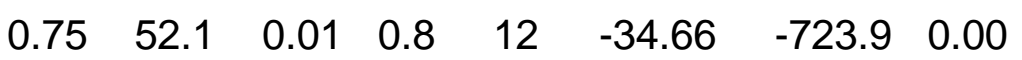

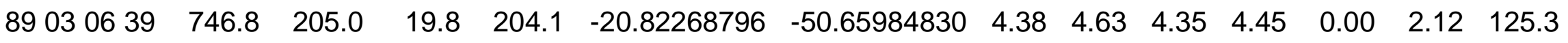

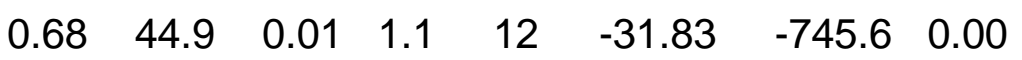

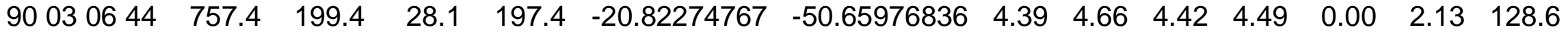

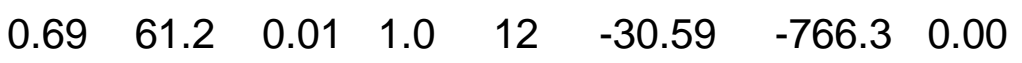

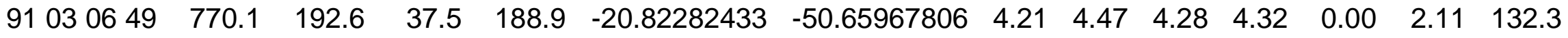

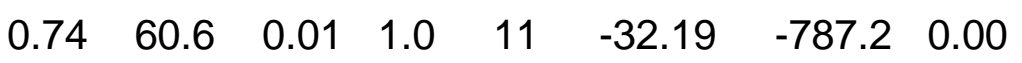

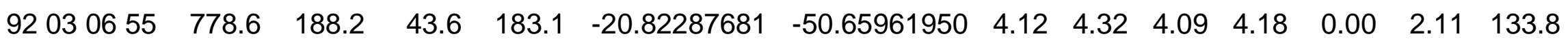

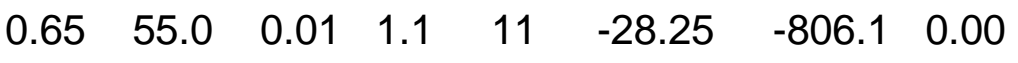

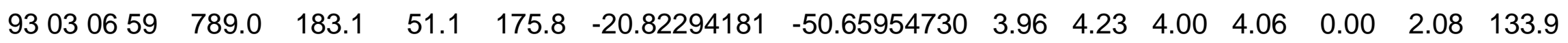

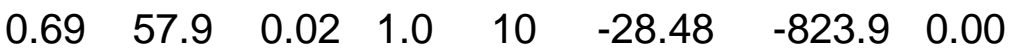




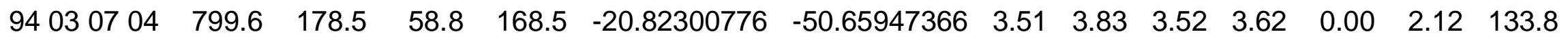

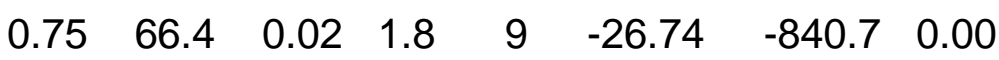

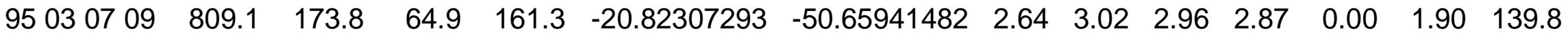

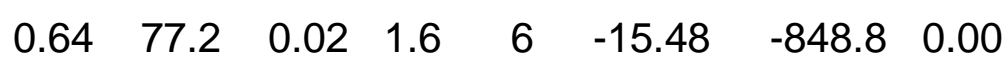

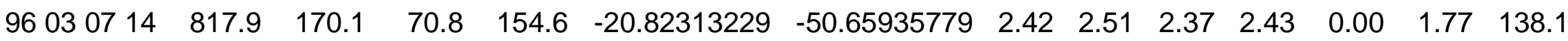

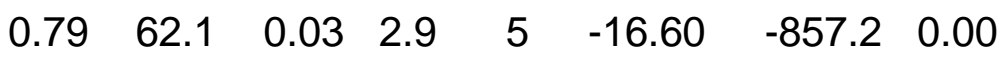

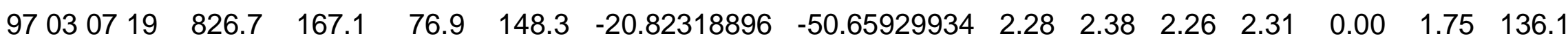

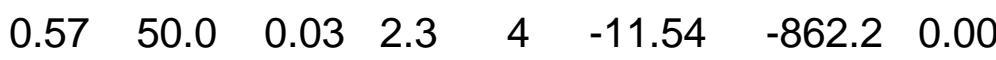

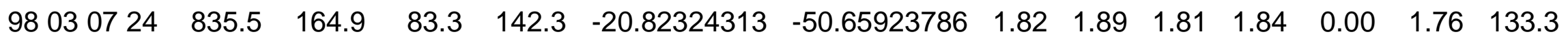

$\begin{array}{llllllll}0.62 & 16.5 & 0.05 & 4.8 & 3 & -8.88 & -865.6 & 0.00\end{array}$

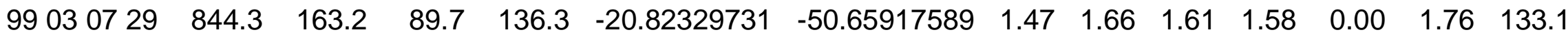

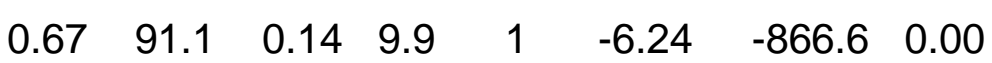

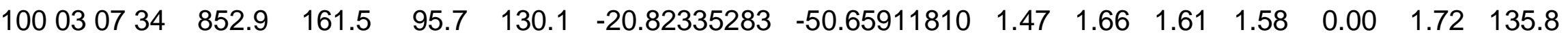

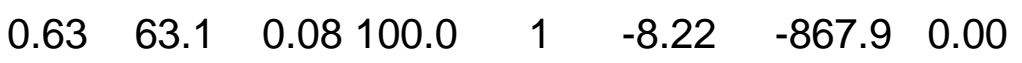

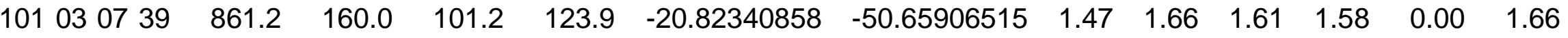

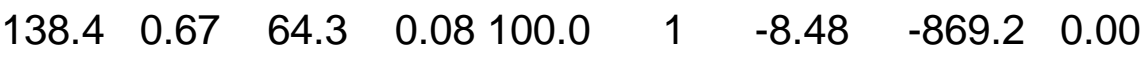

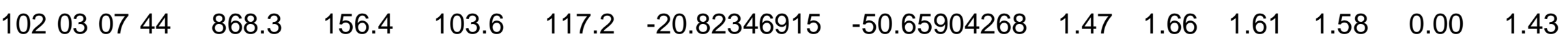

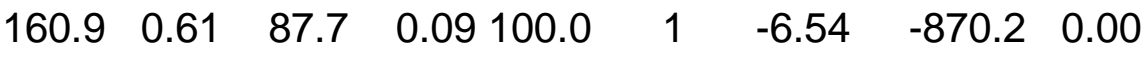

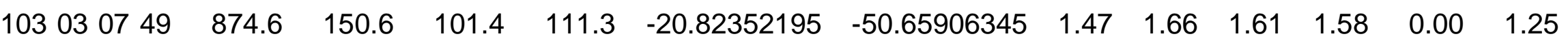

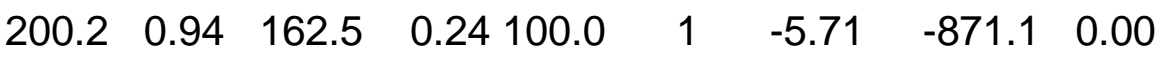




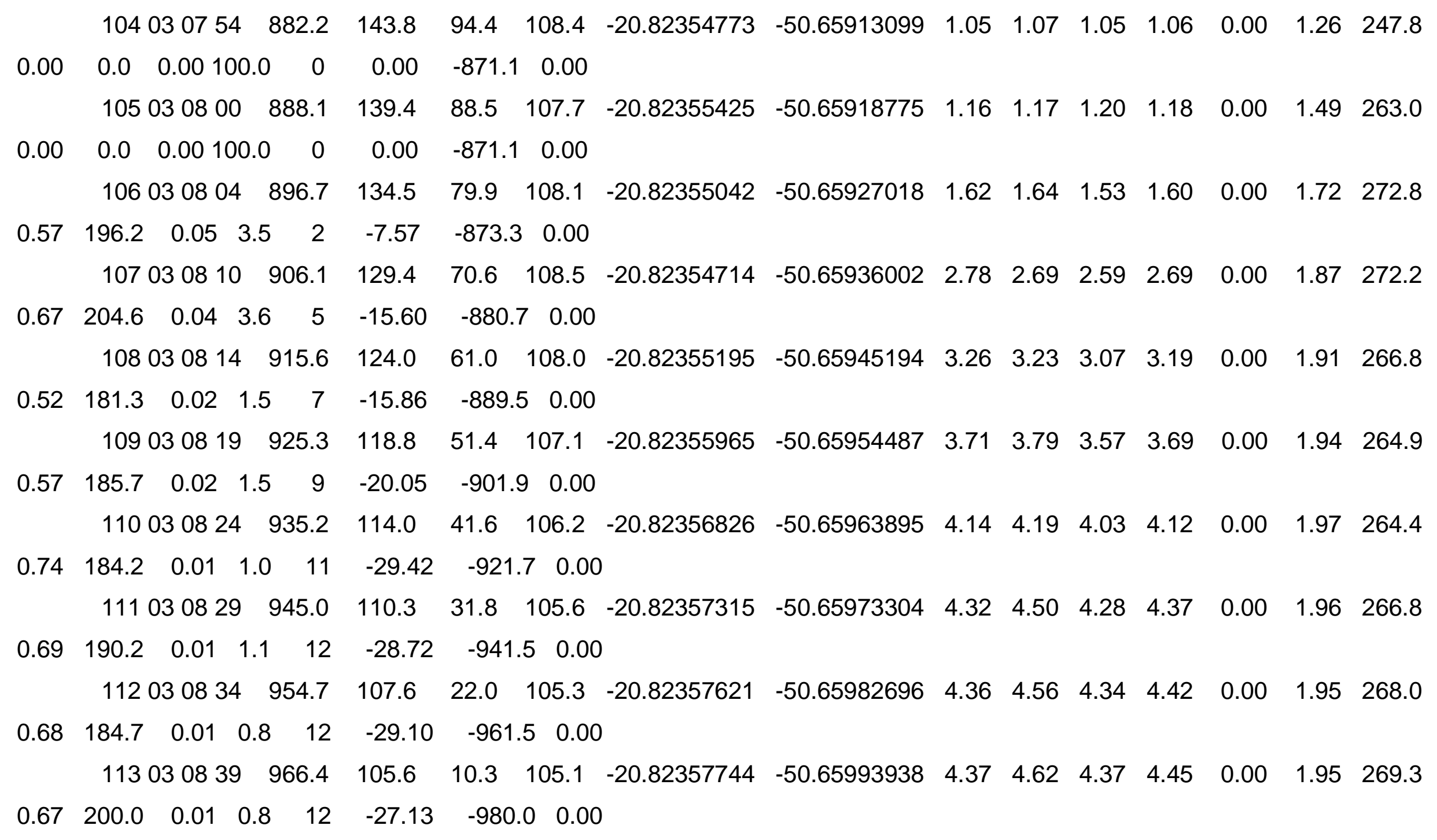




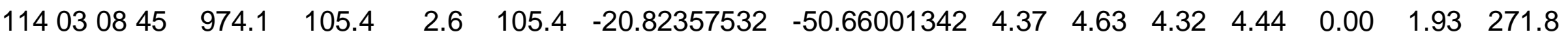

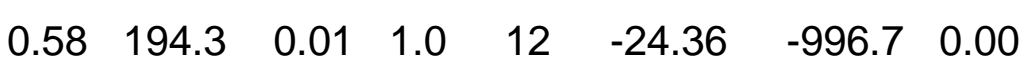

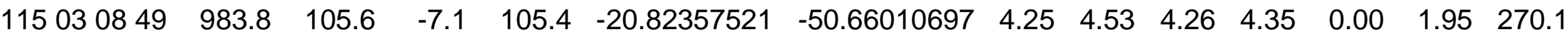

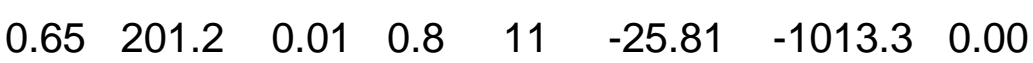

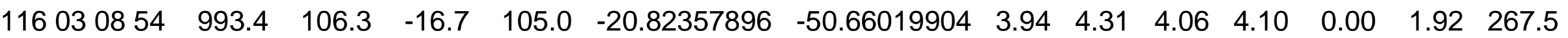

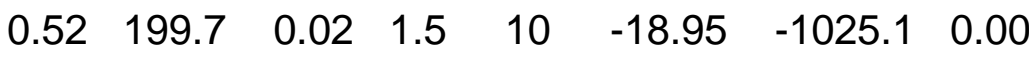

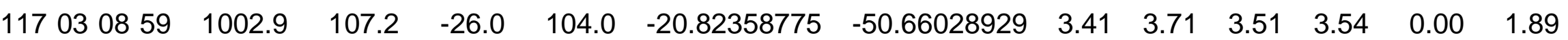

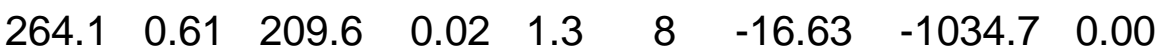

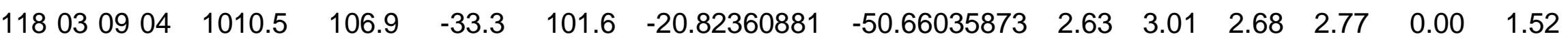

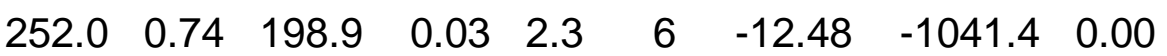

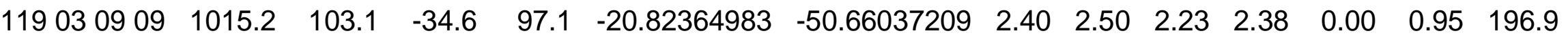

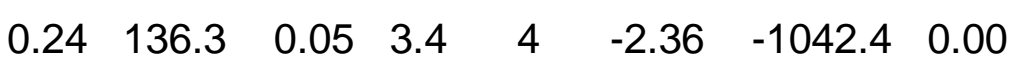

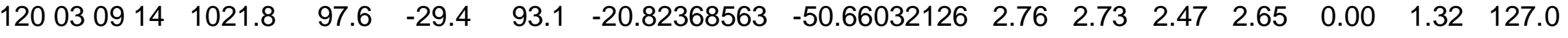

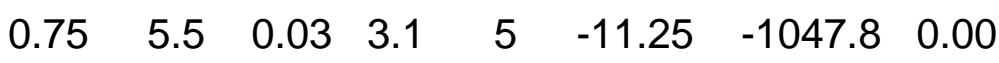

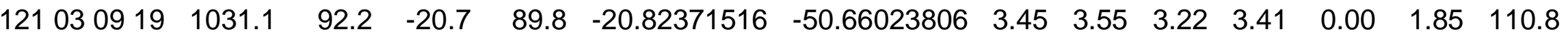

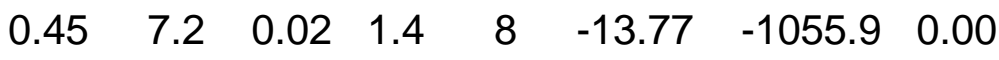

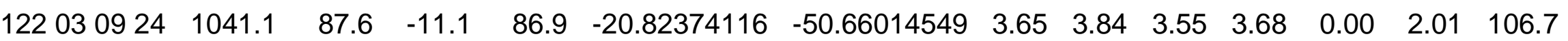

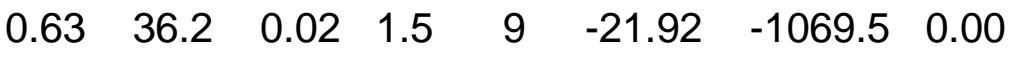

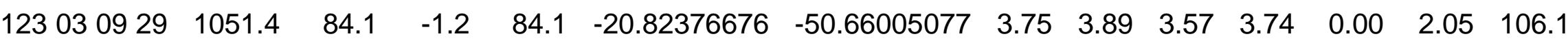

$\begin{array}{llllllll}0.50 & 32.8 & 0.02 & 1.4 & 9 & -18.18 & -1080.6 & 0.00\end{array}$ 


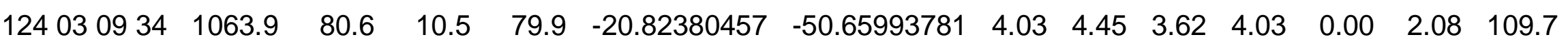

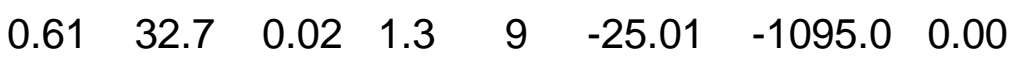

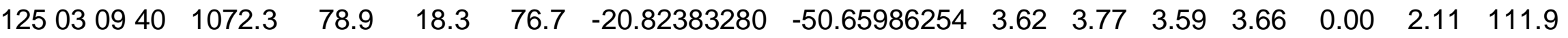

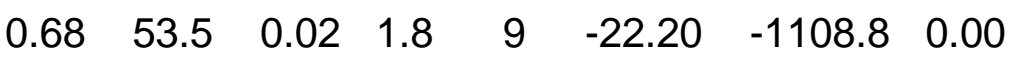

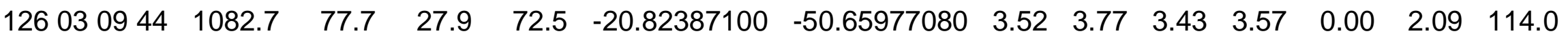

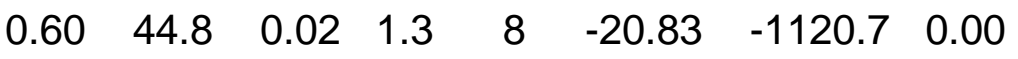

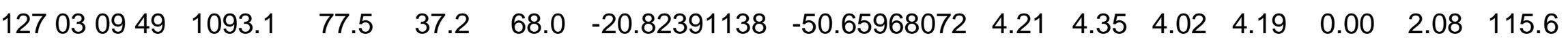

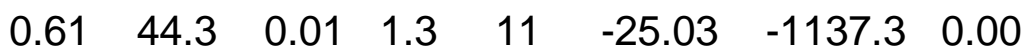

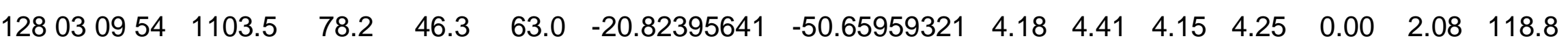

$\begin{array}{llllllll}0.74 & 44.3 & 0.01 & 1.0 & 11 & -31.62 & -1158.1 & 0.00\end{array}$

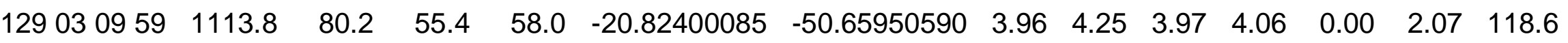

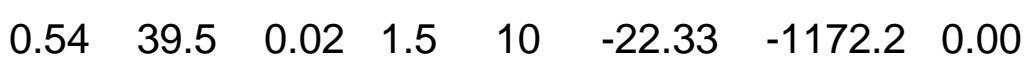

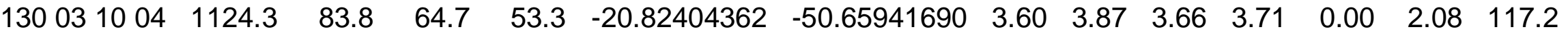

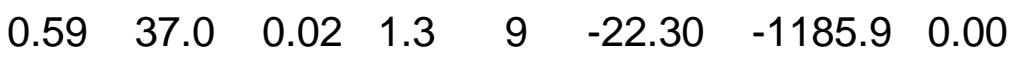

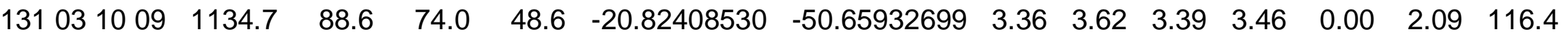

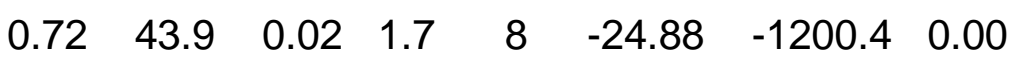

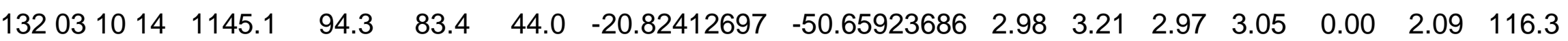

$\begin{array}{llllllll}0.68 & 34.1 & 0.03 & 1.8 & 7 & -21.47 & -1212.8 & 0.00\end{array}$

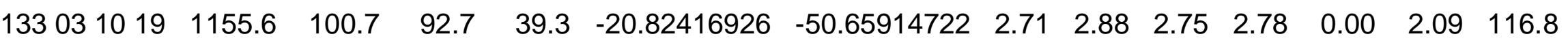

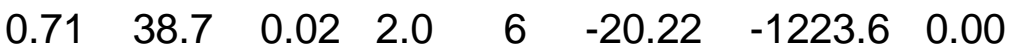




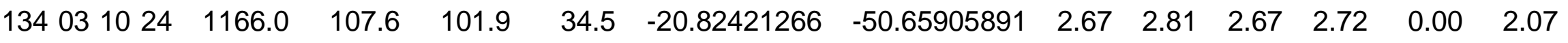
$\begin{array}{lllllllll}117.7 & 0.76 & 41.9 & 0.02 & 1.6 & 6 & -20.74 & -1235.0 & 0.00\end{array}$

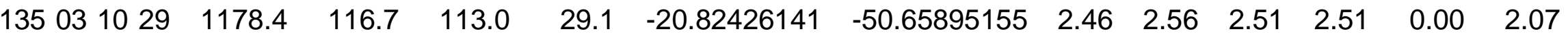

$\begin{array}{lllllllll}115.9 & 0.59 & 32.7 & 0.03 & 1.9 & 5 & -15.16 & -1242.5 & 0.00\end{array}$

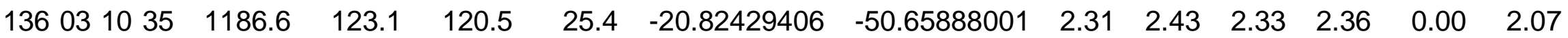

$\begin{array}{lllllllll}116.0 & 0.63 & 34.1 & 0.02 & 2.1 & 4 & -15.24 & -1248.9 & 0.00\end{array}$

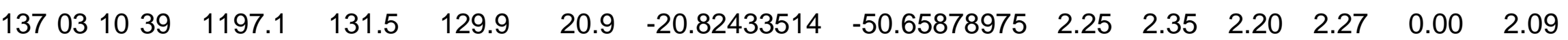

$\begin{array}{lllllllll}116.0 & 0.66 & 38.4 & 0.04 & 2.8 & 4 & -15.28 & -1255.6 & 0.00\end{array}$

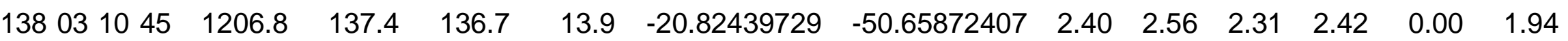

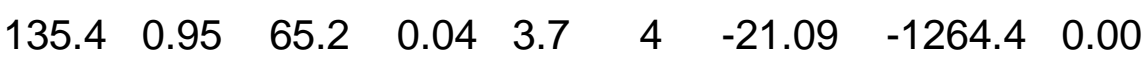

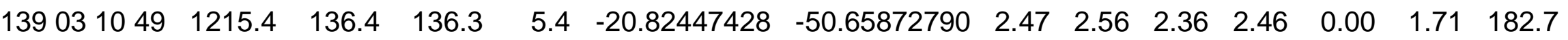

$\begin{array}{llllllll}0.77 & 106.7 & 0.04 & 2.5 & 5 & -15.70 & -1272.3 & 0.00\end{array}$

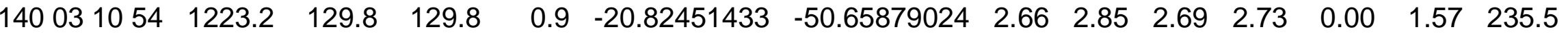

$\begin{array}{llllllll}0.75 & 162.8 & 0.03 & 2.7 & 6 & -15.36 & -1280.6 & 0.00\end{array}$

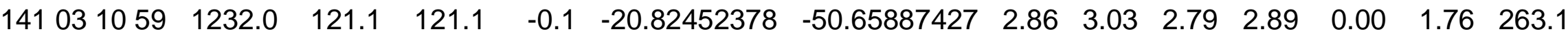

$\begin{array}{llllllll}0.52 & 169.2 & 0.02 & 1.5 & 6 & -13.25 & -1287.5 & 0.00\end{array}$

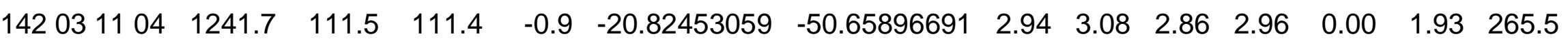

$\begin{array}{llllllll}0.53 & 194.2 & 0.02 & 2.2 & 6 & -14.38 & -1294.9 & 0.00\end{array}$

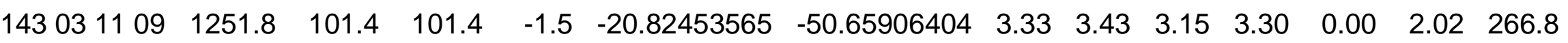
$\begin{array}{llllllll}0.67 & 188.3 & 0.02 & 1.3 & 7 & -21.81 & -1306.7 & 0.00\end{array}$ 


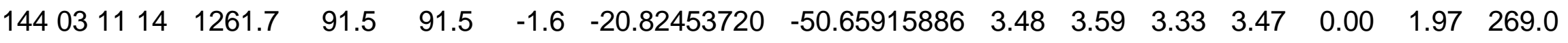

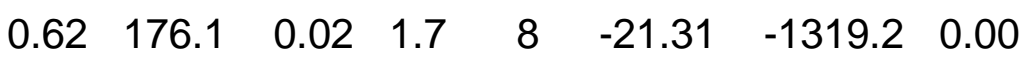

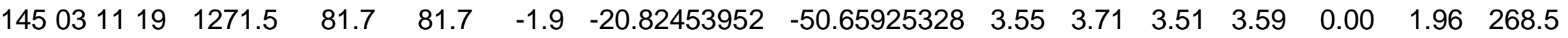

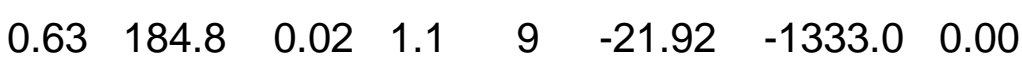

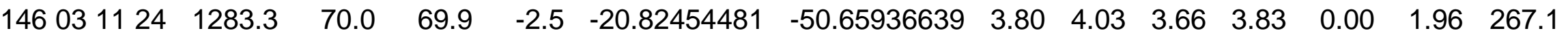

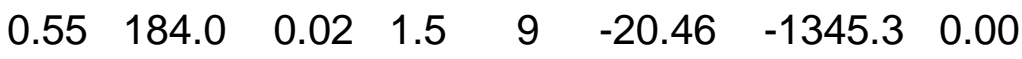

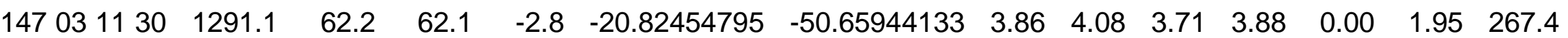

$\begin{array}{llllllll}0.51 & 183.8 & 0.01 & 1.0 & 9 & -19.25 & -1356.7 & 0.00\end{array}$

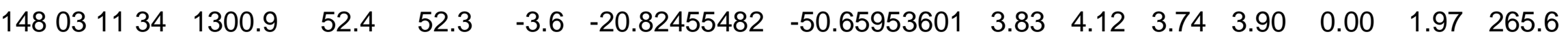

$\begin{array}{llllllll}0.62 & 199.8 & 0.02 & 1.3 & 10 & -21.81 & -1370.8 & 0.00\end{array}$

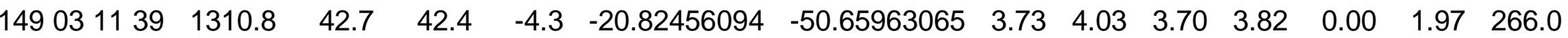

$\begin{array}{llllllll}0.50 & 183.0 & 0.02 & 1.4 & 9 & -18.83 & -1382.1 & 0.00\end{array}$

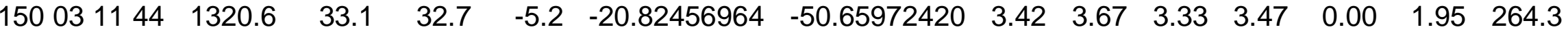

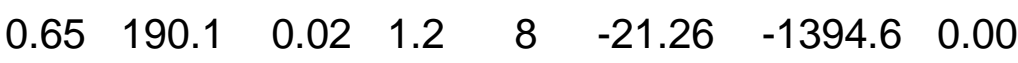

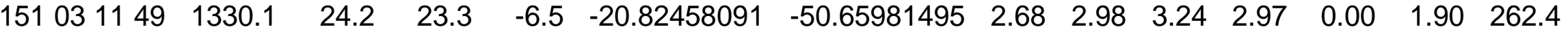

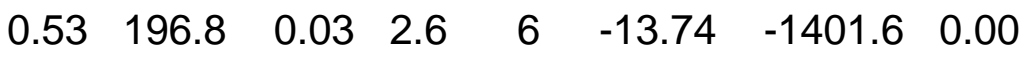

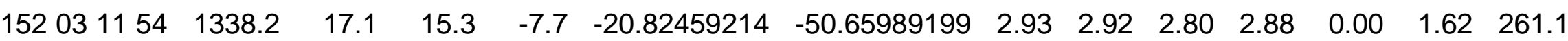

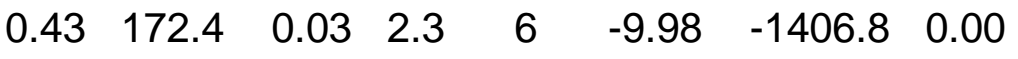

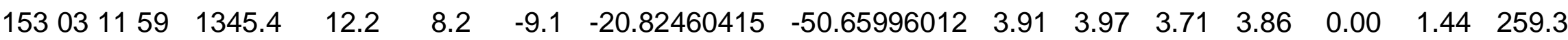

$\begin{array}{llllllll}0.43 & 183.3 & 0.01 & 1.1 & 9 & -11.66 & -1413.8 & 0.00\end{array}$ 
Apêndice 2

Modelo de Ficha Adotado na Avaliação Geoambiental 


\section{Modelo de Formulário}

Data:
Aplicador:
Localidade:
Nome da drenagem:
Coordenadas (UTM):
Hierarquia da drenagem:
Escala de estudo: ( ) Drenagem ( ) Sub-bacia ( ) Bacia
Localização da área: ( ) Continente ( ) Estuário
Tamanho da área de estudo:
Margem: ( ) Direita ( ) Esquerda ( ) Canal （ ) Banco de areia/ilha fluvial

\section{Parâmetros climáticos}

Tabela 72 - Tipo climático local (Köppen-Geiger).

\begin{tabular}{|c|c|c|}
\hline Tipologia & Volume (mm/ano) & Peso \\
\hline Tropical (A) & $>1.500$ & 1 \\
\hline Árido (B) & $\begin{array}{c}\text { Climas secos e precipitação } \\
\text { anual inferior a 500mm }\end{array}$ & 9 \\
\hline Temperado (C) & $\begin{array}{c}? 1.100-2.000 ? \\
\text { Estações de Verão e Inverno } \\
\text { bem definidas }\end{array}$ & 5 \\
\hline Continental (D) & $\begin{array}{c}\text { Estações de Verão e Inverno } \\
\text { bem definidas }\end{array}$ & 9 \\
\hline Glacial (E) & $\begin{array}{c}\text { Estação do Verão pouco definida } \\
\text { ou inexistente, podendo ser } \\
\text { definido como Climas polares e } \\
\text { de alta montanha }\end{array}$ & 5 \\
\hline Não classificado & Ausência de dados & \\
\hline
\end{tabular}


Tabela 73 - Tipo climático local - Köppen-Geiger (PEEL; FINLAYSON; MCMAHON, 2007).

\begin{tabular}{|c|c|c|}
\hline Tipologia & Precipitação pluviométrica & Peso \\
\hline S & Precipitação anual total média entre 380 e $760 \mathrm{~mm}$ & 5 \\
\hline W & Precipitação anual total média < 250mm & 8 \\
\hline f & $\begin{array}{c}\text { Ausência de estação seca definida e ocorrência de precipitação } \\
\text { pluviométrica em todos os meses do ano. }\end{array}$ & 1 \\
\hline w & Chuvas de Verão & 9 \\
\hline S & Chuvas de Inverno & 9 \\
\hline w' Chuvas de Verão-outono & 8 \\
\hline s' & Chuvas de Inverno-outono & 8 \\
\hline m & Precipitação do mês mais seco < 60mm & 7 \\
\hline T & Temperatura média do ar no mês mais quente compreendida entre & 7 \\
\hline F & Temperatura média do mês mais quente < $0^{\circ} \mathrm{C}$ & 8 \\
\hline M & Precipitação abundante e Inverno pouco rigoroso & 6 \\
\hline
\end{tabular}

Tabela 74 - Temperatura média - Köppen-Geiger (PEEL; FINLAYSON; MCMAHON, 2007).

\begin{tabular}{|c|c|c|}
\hline Tipologia & Temperatura média do ar & Peso \\
\hline a & Temperatura média do ar no mês mais quente $\geq 22^{\circ} \mathrm{C}$ & 7 \\
\hline b & Temperatura média do ar no mês mais quente $<22^{\circ} \mathrm{C}$ & 1 \\
\cline { 2 - 3 } & Temperaturas médias do ar nos 4 meses mais quentes $>10^{\circ} \mathrm{C}$ & 7 \\
\hline \multirow{2}{*}{$\mathrm{c}$} & Temperatura média do ar no mês mais quente $<22^{\circ} \mathrm{C}$ & 6 \\
\cline { 2 - 3 } & Temperaturas médias do ar $>10^{\circ} \mathrm{C}$ durante menos de 4 meses & 6 \\
\cline { 2 - 3 } & Temperatura média do ar no mês mais frio $>-38^{\circ} \mathrm{C}$ & 9 \\
\hline $\mathrm{d}$ & Temperatura média do ar no mês mais frio $<-38^{\circ} \mathrm{C}$ & 9 \\
\hline & Temperatura média anual do ar $>18^{\circ} \mathrm{C}$ & 9 \\
\cline { 2 - 3 } & Temperatura media anual do ar $<18^{\circ} \mathrm{C}$ & 5 \\
\hline $\mathrm{k}$ & Deserto ou semi-deserto frio (temperatura anual média do ar & 6 \\
\cline { 2 - 3 } & inferior a $\left.18^{\circ} \mathrm{C}\right)$ & \\
\hline
\end{tabular}


Pontuação Parcial

\begin{tabular}{|c|c|}
\hline Limite & Classificação parcial \\
\hline $3-14$ & Baixo \\
\hline $15-18$ & Médio \\
\hline $19-27$ & Alto \\
\hline
\end{tabular}

\section{Parâmetros Geológicos (Condição do material geológico)}

Tabela 75 - Natureza do substrato.

\begin{tabular}{|c|c|}
\hline Litologia & Peso \\
\hline Solo & 8 \\
\hline Depósito sedimentar & 9 \\
\hline Rocha ígnea & 1 \\
\hline Rocha metamórfica & 2 \\
\hline Rocha sedimentar & 5 \\
\hline Contato geológico & 9 \\
\hline
\end{tabular}

Tabela 76 - Tipos de solos.

\begin{tabular}{|c|c|}
\hline Tipo de solo & Peso \\
\hline Aluvião & 9 \\
\hline Aterro & 6 \\
\hline Depósito sedimentar & 9 \\
\hline $\begin{array}{c}\text { Depósito sedimentar } \\
\text { pedogenisado }\end{array}$ & 5 \\
\hline Orgânico & 5 \\
\hline Paleossolo & 5 \\
\hline Solo residual jovem & 1 \\
\hline Solo residual maduro & 3 \\
\hline Transportado & 9 \\
\hline Contato geológico & 9 \\
\hline Ausente & 1 \\
\hline
\end{tabular}


Pontuação Parcial

\begin{tabular}{|c|c|}
\hline Limite & Classificação párcial \\
\hline $1-8$ & Baixo \\
\hline $9-13$ & Médio \\
\hline $14-18$ & Alto \\
\hline
\end{tabular}

\section{Parâmetros Geomorfológicos}

Tabela 77 - Tipos de vales fluviais

\begin{tabular}{|c|c|}
\hline Tipologia & Peso \\
\hline $\mathrm{U}$ & 8 \\
\hline $\mathrm{V}$ & 9 \\
\hline Tabular & 7 \\
\hline Irregular & 8 \\
\hline Cruzado & 9 \\
\hline
\end{tabular}

Tabela 78 - Tipo de canal fluvial.

\begin{tabular}{|c|c|}
\hline Tipo de canal & Peso \\
\hline Retilíneo & 3 \\
\hline Meandrante & 9 \\
\hline Anastomosados & 5 \\
\hline Entrelaçados & 6 \\
\hline
\end{tabular}

Tabela 79 - Grau de Inclinação do terreno (EMBRAPA, 1979).

\begin{tabular}{|c|c|c|}
\hline Tipologia & Inclinação (\%) & Peso \\
\hline Plana & $0-3$ & 5 \\
\hline Suave Ondulada & $3-8$ & 7 \\
\hline Ondulada & $8-20$ & 9 \\
\hline Muito Ondulada & $20-45$ & 8 \\
\hline Forte Ondulada & $45-75$ & 6 \\
\hline Uso Restrito & $>75$ & \\
\hline
\end{tabular}


Tabela 80 - Tipo de vertentes (adaptado de NBR 11682, 2006).

\begin{tabular}{|c|c|}
\hline Tipologia & Peso \\
\hline Convexa & 9 \\
\hline Côncava & 5 \\
\hline Convexa-Côncava & 6 \\
\hline Côncava-Convexa & 3 \\
\hline Retilínea & 1 \\
\hline
\end{tabular}

Pontuação Parcial

\begin{tabular}{|c|c|}
\hline Limite & Classificação párcial \\
\hline $12-22$ & Baixo \\
\hline $23-26$ & Médio \\
\hline $27-36$ & Alto \\
\hline
\end{tabular}

\section{Parâmetros hidráulicos}

Tabela 81 - Tipo de regime.

\begin{tabular}{|c|c|}
\hline Tipologia & Peso \\
\hline Perene & 9 \\
\hline Intermitente & 7 \\
\hline Irregular & 5 \\
\hline Caótico & 6 \\
\hline
\end{tabular}

Tabela 82 - Vazão $\left(\mathrm{m}^{3}\right)$.

\begin{tabular}{|c|c|c|}
\hline Grau & Variação $\left(\mathbf{m}^{3 / \mathbf{s}}\right)$ & Peso \\
\hline Muito baixa & $\leq 1$ & 8 \\
\hline Baixa & $1-100$ & 7 \\
\hline Normal & 500 & 5 \\
\hline Alta & 1.000 & 9 \\
\hline Muito alta & $\geq 10.000$ & 9 \\
\hline Ausência de vazão & - & 5 \\
\hline Não mensurado & - & 8 \\
\hline
\end{tabular}


Tabela 83 - Ocorrência de nascente.

\begin{tabular}{|c|c|}
\hline Tipologia & Peso \\
\hline Ausente & 1 \\
\hline Presente & 9 \\
\hline Não observado & 5 \\
\hline
\end{tabular}

Tabela 84 - Sólidos em suspenção (\% de sedimento/ 500ml)

\begin{tabular}{|c|c|c|}
\hline Tipologia (\%) & Parâmetro (\%) & Peso \\
\hline Muito baixa & $0-4$ & 3 \\
\hline Baixa & $5-9$ & 5 \\
\hline Normal & $10-24$ & 9 \\
\hline Alta & $25-49$ & 5 \\
\hline Muito alta & $\geq 50$ & 5 \\
\hline
\end{tabular}

Pontuação Parcial

\begin{tabular}{|c|c|}
\hline Limite & Grau de influência \\
\hline $12-21$ & Baixo \\
\hline $22-27$ & Médio \\
\hline $28-36$ & Alto \\
\hline
\end{tabular}




\section{Parâmetros Geotécnicos}

Tabela 85 - Textura dos solos (granulometria).

\begin{tabular}{|c|c|}
\hline Tipologia & Peso \\
\hline Arenosa & 9 \\
\hline Areia franca & 8 \\
\hline Areia siltosa & 9 \\
\hline Franco arenoso & 7 \\
\hline Franco argilosa-arenoso & 7 \\
\hline Franco argilosa & 5 \\
\hline Areia argilosa & 8 \\
\hline Argilosa & 5 \\
\hline Argila siltosa & 8 \\
\hline Franco argilo-siltoso & 6 \\
\hline Franco siltoso & 6 \\
\hline Siltoso & 6 \\
\hline Silte arenoso & 9 \\
\hline Franco & 5 \\
\hline
\end{tabular}

Tabela 86 - Permeabilidade dos solos (adaptado de STANCATI; NOGUEIRA; MONJEVILAR, 1981 apud LORANDI et al., 2001).

\begin{tabular}{|c|c|c|}
\hline Tipo de solo & Parâmetro $(\mathbf{c m} / \mathbf{s})$ & Peso \\
\hline Praticamente Impermeável & $<10^{-7} \mathrm{~cm} / \mathrm{s}$ & 7 \\
\hline Muito Baixa & $10^{-5} \mathrm{a} 10^{-1} \mathrm{~cm} / \mathrm{s}$ & 5 \\
\hline Baixa & $10^{-3} \mathrm{a} 10^{-5} \mathrm{~cm} / \mathrm{s}$ & 3 \\
\hline Média & $10^{-1} \mathrm{a} 10^{-3} \mathrm{~cm} / \mathrm{s}$ & 1 \\
\hline Alta & $<10^{-1} \mathrm{~cm} / \mathrm{s}$ & 7 \\
\hline
\end{tabular}

Tabela 87 - Teor de matéria orgânica dos solos.

\begin{tabular}{|c|c|c|}
\hline Tipologia (\%) & Matéria Orgânica (\%) & Peso \\
\hline Muito baixa & $0-4$ & 3 \\
\hline Baixa & $5-9$ & 5 \\
\hline Normal & $10-24$ & 7 \\
\hline Alta & $25-49$ & 9 \\
\hline Muito alta & $\geq 50$ & 5 \\
\hline Não mensurado & - & 1 \\
\hline
\end{tabular}


Tabela 88 - Grau de Saturação (adaptado de IAEG, 1979).

\begin{tabular}{|c|c|c|}
\hline Tipo de solo & Grau de Saturação (\%) & Peso \\
\hline Naturalemente seco & $0-24$ & 9 \\
\hline Úmido & $25-0,49$ & 5 \\
\hline Muito úmido & $0,50-0,79$ & 7 \\
\hline Altamente saturado & $0,80-0,94$ & 9 \\
\hline Saturado & $0,95-1,00$ & 5 \\
\hline Não mensurado & - & \\
\hline
\end{tabular}

Tabela 89 - Problemas geotécnicos.

\begin{tabular}{|c|c|}
\hline Tipologia & Peso \\
\hline Assoreamento & 9 \\
\hline Ausente & 1 \\
\hline Enchente & 9 \\
\hline Erosão linear & 7 \\
\hline Erosão por Piping & 8 \\
\hline Fluxo de detritos & 9 \\
\hline Inundações & 8 \\
\hline Mixto & 9 \\
\hline Outros & 5 \\
\hline Presença de cunha & 8 \\
\hline Queda de blocos & 6 \\
\hline Ravina & 8 \\
\hline Recalque & 9 \\
\hline Ruptura de talude & 7 \\
\hline Solapamento basal & 8 \\
\hline Tombamento & 8 \\
\hline Voçoroca & 9 \\
\hline
\end{tabular}

Pontuação Parcial

\begin{tabular}{|c|c|}
\hline Limite & Grau de influência \\
\hline $9-32$ & Baixo \\
\hline $33-37$ & Médio \\
\hline $38-45$ & Alto \\
\hline
\end{tabular}




\section{Parâmetros ecológicos}

Tabela 90 - Faixa marginal (mata ciliar).

\begin{tabular}{|c|c|}
\hline Tipologia & Peso \\
\hline Presente & 1 \\
\hline Ausente & 9 \\
\hline
\end{tabular}

Tabela 91 - Característica da faixa marginal (mata ciliar).

\begin{tabular}{|c|c|}
\hline Tipologia & Peso \\
\hline Continua & 1 \\
\hline Descontínua & 7 \\
\hline Irregular & 6 \\
\hline Ausente & 9 \\
\hline
\end{tabular}

Tabela 92 - Aspécto vegetacional da mata ciliar.

\begin{tabular}{|c|c|}
\hline Tipologia & Peso \\
\hline Arbórea & 1 \\
\hline Arbustiva & 6 \\
\hline Reflorestada & 5 \\
\hline Desmatada & 9 \\
\hline
\end{tabular}

Tabela 93 - Tipo de vegetação na drenagem (fixação ao leito).

\begin{tabular}{|c|c|}
\hline Tipologia & Peso \\
\hline Fixa & 1 \\
\hline Flutuante & 5 \\
\hline Mista & 3 \\
\hline Ausente & 9 \\
\hline
\end{tabular}

Tabela 94 - Cobertura do solo da mata cilitar.

\begin{tabular}{|c|c|}
\hline Tipologia & Peso \\
\hline Solo com serrapilheira & 1 \\
\hline Solo exposto & 9 \\
\hline Material compactado & 8 \\
\hline
\end{tabular}


Pontuação Parcial

\begin{tabular}{|c|c|}
\hline Limite & Grau de influência \\
\hline $5-16$ & Baixo \\
\hline $17-27$ & Médio \\
\hline $28-45$ & Alto \\
\hline
\end{tabular}

\section{Uso e ocupação ao longo da drenagem}

Tabela 95 - Infra-estruturas públicas e privadas

\begin{tabular}{|c|c|}
\hline Tipologia & Peso \\
\hline Ausente & 1 \\
\hline Duto/ tubulação & 7 \\
\hline Estrada de terra & 8 \\
\hline Estrada em paralelepípedo & 6 \\
\hline Estrada pavimentada & 9 \\
\hline Galeria pluvial & 5 \\
\hline Outras & 5 \\
\hline Ponte com fundação nas margens & 9 \\
\hline Ponte com fundação no canal & 9 \\
\hline Viaduto & 9 \\
\hline
\end{tabular}

Tabela 96 - Tipo de uso e ocupação

\begin{tabular}{|c|c|}
\hline Tipologia & Peso \\
\hline Agricultura & 7 \\
\hline Área natural & 1 \\
\hline Hidrovia & 5 \\
\hline Industrial & 7 \\
\hline Lazer & 6 \\
\hline Mineração & 9 \\
\hline Misto & 9 \\
\hline Pastagem & 9 \\
\hline Urbano & 7 \\
\hline
\end{tabular}


Tabela 97 - Tipo de animal Valores da massa, área do casco e pressão de animais do Vale do Pajeú, em Pernambuco (adaptado de SOUSA et al., 1998 apud SOUSA et al., 1998).

\begin{tabular}{|c|c|}
\hline Animal & Peso \\
\hline Bovino & 9 \\
\hline Novilho & 7 \\
\hline Bezerro & 6 \\
\hline Equino & 6 \\
\hline Caprino & 5 \\
\hline Muar & 5 \\
\hline Asinino & 6 \\
\hline Ausente & 1 \\
\hline
\end{tabular}

Tabela 98 - № de animais por hectare.

\begin{tabular}{|c|c|c|c|c|c|c|}
\hline \multirow[t]{2}{*}{ Tipologia } & \multicolumn{5}{|c|}{$\mathrm{N}^{\circ}$ de animais } & \multirow{13}{*}{$\begin{array}{l}\text { D } \\
\text { \& }\end{array}$} \\
\hline & 1 & 5 & 10 & 50 & $\geq 100$ & \\
\hline Bovino & 5 & 6 & 7 & 8 & 9 & \\
\hline Novilho & 3 & 4 & 5 & 6 & 7 & \\
\hline Bezerro & 2 & 3 & 4 & 5 & 6 & \\
\hline Equino & 2 & 3 & 4 & 5 & 6 & \\
\hline Caprino & 1 & 2 & 3 & 4 & 5 & \\
\hline Muar & 1 & 2 & 3 & 4 & 5 & \\
\hline Asinino & 2 & 3 & 4 & 5 & 6 & \\
\hline Outros & 5 & 5 & 5 & 5 & 5 & \\
\hline \multirow[t]{3}{*}{ Ausente } & \multicolumn{5}{|c|}{1} & \\
\hline & 1 & 5 & 10 & 50 & $\geq 100$ & \\
\hline & \multicolumn{5}{|c|}{ Hectare } & \\
\hline
\end{tabular}


Tabela 99 - Tipo de pastagem.

\begin{tabular}{|c|c|}
\hline Tipologia & Peso \\
\hline Livre & 9 \\
\hline Confinada & 5 \\
\hline Mista & 7 \\
\hline Ausente & 1 \\
\hline
\end{tabular}

Tabela 100 - Planejamento do uso do solo.

\begin{tabular}{|c|c|}
\hline Tipologia & Peso \\
\hline Presente & 1 \\
\hline Ausente & 9 \\
\hline
\end{tabular}

Tabela 101 - Infra-estruturas pra controle de erosão

\begin{tabular}{|c|c|}
\hline Tipologia & Peso \\
\hline Piscinão & 5 \\
\hline Estruturas em rocha (gabião) & 5 \\
\hline Estruturas em solo (aterro) & 6 \\
\hline Murro de contenção & 3 \\
\hline Cortina atirantada & 3 \\
\hline Concreto projetado & 3 \\
\hline Coluna de Jet grouting & 3 \\
\hline Ausente & 9 \\
\hline Sem erosão & 1 \\
\hline
\end{tabular}

Tabela 102 - Tipo de Manejo (VIEIRA et al., 1996; BERTONI \& LOMBARDI NETO, 1999).

\begin{tabular}{|c|c|}
\hline Tipologia & Peso \\
\hline Cultivo anual & 9 \\
\hline Cordões de vegetação permanente & 3 \\
\hline Rotação de cultura & 5 \\
\hline Cultivo em faixa & 3 \\
\hline Misto & 3 \\
\hline Defensivos agrícolas & 5 \\
\hline Outros & 5 \\
\hline Ausente & 9 \\
\hline Sem cultivo & 1 \\
\hline
\end{tabular}


Tabela 103 - Localização do cultivo agrícola na planície fluvial.

\begin{tabular}{|c|c|}
\hline Tipologia & Peso \\
\hline Ausente & 1 \\
\hline Em área alagada & 3 \\
\hline Em curva de nível & 5 \\
\hline Em declive & 9 \\
\hline Em faixa & 5 \\
\hline Em planície & 1 \\
\hline Em terraço & 3 \\
\hline Sem cultivo & 1 \\
\hline
\end{tabular}

Tabela 104 - Tipo de cultura (adaptado de BERTONI \& LOMBARDI NETO, 1999; PONS, 2006 apud CEREDA JUNIOR, 2006).

\begin{tabular}{|c|c|}
\hline Tipologia & Peso \\
\hline Arroz & 6 \\
\hline Banana & 5 \\
\hline Cana de açúcar & 3 \\
\hline Feijão & 9 \\
\hline Hortaliça & 7 \\
\hline Laranja & 4 \\
\hline Milho & 3 \\
\hline Outras culturas & 5 \\
\hline Soja & 5 \\
\hline Sem cultura agrícola & 1 \\
\hline
\end{tabular}

Pontuação Parcial

\begin{tabular}{|c|c|}
\hline Limite & Grau de influência \\
\hline $9-22$ & Baixo \\
\hline $23-46$ & Médio \\
\hline $47-90$ & Alto \\
\hline
\end{tabular}


Tabela 105 - Somatório total da pontuação para classificação final do curso d'água.

\begin{tabular}{|c|c|c|}
\hline ¿total Limite & Classificação & Classe \\
\hline$<83$ & Natural & I \\
\hline $84-141$ & Levemente alterado & II \\
\hline $142-193$ & Alterado & IV \\
\hline $194-234$ & Muito altado & V \\
\hline$>235$ & Degradado & \\
\hline
\end{tabular}




\section{Apêndice 3}

Tabela 106 - Ensaio de granulometria dos materias geológicos da área de estudo.

\begin{tabular}{|c|c|c|c|c|c|c|c|c|}
\hline \multirow{2}{*}{ A } & \multicolumn{8}{|c|}{ № das Peneiras } \\
\hline & $2 \mu$ & 200 & 100 & 50 & 30 & 16 & 10 & 4 \\
\hline 1 & 14,24 & 26,58 & 65,07 & 27,41 & 14,82 & 0,12 & 0,00 & 0,00 \\
\hline 2 & 11,09 & 37,26 & 86,31 & 13,06 & 1,60 & 0,00 & 0,00 & 0,00 \\
\hline 3 & 4,06 & 98,74 & 98,75 & 13,76 & 1,72 & 0,30 & 0,00 & 0,00 \\
\hline 4 & 4,29 & 27,50 & 67,75 & 21,90 & 12,65 & 6,06 & 11,96 & 0,00 \\
\hline 5 & 4,57 & 23,76 & 98,36 & 19,29 & 0,00 & 0,61 & 0,16 & 0,00 \\
\hline 6 & 17,71 & 33,00 & 74,22 & 20,84 & 2,63 & 0,52 & 0,07 & 0,00 \\
\hline 7 & 21,10 & 33,10 & 58,18 & 21,15 & 8,48 & 5,92 & 0,12 & 0,00 \\
\hline 8 & 4,31 & 18,31 & 96,98 & 27,74 & 5,56 & 0,43 & 0,47 & 0,00 \\
\hline 9 & 3,67 & 20,58 & 99,49 & 24,90 & 0,62 & 0,13 & 0,00 & 0,00 \\
\hline 10 & 18,78 & 40,12 & 79,03 & 8,74 & 1,24 & 0,47 & 0,00 & 0,00 \\
\hline 11 & 23,27 & 47,38 & 65,86 & 10,53 & 1,78 & 0,19 & 0,10 & 0,00 \\
\hline 12 & 18,05 & 47,72 & 69,21 & 11,85 & 1,70 & 0,49 & 0,04 & 0,00 \\
\hline 13 & 6,22 & 24,29 & 80,95 & 21,12 & 8,66 & 3,48 & 9,29 & 0,00 \\
\hline 14 & 24,70 & 39,00 & 55,36 & 17,33 & 7,85 & 4,34 & 0,03 & 0,00 \\
\hline 15 & 20,90 & 41,50 & 50,78 & 14,15 & 11,93 & 9,73 & 0,21 & 0,00 \\
\hline 16 & 1,06 & 11,84 & 119,61 & 17,45 & 0,25 & 0,02 & 0,00 & 0,00 \\
\hline 17 & 12,46 & 34,78 & 217,31 & 47,20 & 10,00 & 15,50 & 49,95 & 13,78 \\
\hline 18 & 47,06 & 66,41 & 22,78 & 7,27 & 5,10 & 0,10 & 0,25 & 0,00 \\
\hline 19 & 9,00 & 51,37 & 85,75 & 2,44 & 0,30 & 0,06 & 0,00 & 0,00 \\
\hline 20 & 6,67 & 34,60 & 103,24 & 5,25 & 0,07 & 0,01 & 0,00 & 0,00 \\
\hline 21 & 50,78 & 77,95 & 6,80 & 4,41 & 7,70 & 1,27 & 0,00 & 0,00 \\
\hline 22 & 11,02 & 36,93 & 84,67 & 12,41 & 2,56 & 1,38 & 0,26 & 0,00 \\
\hline 23 & 3,65 & 30,86 & 101,28 & 13,17 & 0,37 & 0,17 & 0,32 & 0,00 \\
\hline 24 & 3,56 & 38,15 & 94,66 & 12,67 & 0,30 & 0,06 & 0,00 & 0,00 \\
\hline 25 & 28,94 & 51,89 & 57,26 & 9,35 & 4,48 & 0,83 & 0,93 & 0,00 \\
\hline 26 & 7,27 & 38,27 & 97,83 & 9,56 & 1,27 & 0,04 & 0,00 & 0,00 \\
\hline 27 & 5,41 & 28,87 & 97,38 & 19,98 & 2,58 & 0,06 & 0,04 & 0,00 \\
\hline 28 & 23,09 & 30,82 & 32,11 & 7,34 & 14,96 & 7,95 & 7,42 & 0,00 \\
\hline 29 & 27,53 & 37,45 & 47,82 & 9,22 & 13,61 & 8,52 & 9,02 & 0,00 \\
\hline 30 & 19,04 & 58,28 & 57,57 & 7,94 & 5,42 & 0,79 & 0,03 & 0,00 \\
\hline 31 & 17,88 & 40,89 & 71,76 & 15,33 & 2,67 & 0,20 & 0,06 & 0,00 \\
\hline 32 & 5,39 & 22,85 & 61,73 & 21,84 & 15,97 & 5,60 & 7,43 & 0,00 \\
\hline 33 & 5,39 & 22,85 & 61,73 & 21,84 & 15,97 & 7,10 & 5,42 & 0,00 \\
\hline
\end{tabular}

Legenda: $A=№$ da amostra; $h=$ percentual de umidade. 
Continuação da tabela 106

\begin{tabular}{|c|c|c|c|c|c|c|c|c|c|}
\hline \multirow[b]{2}{*}{$A$} & \multicolumn{8}{|c|}{ № das Peneiras } & \multirow{2}{*}{$\begin{array}{l}\mathrm{H} \\
(\%)\end{array}$} \\
\hline & 1" & $3 / 4$ & $5 / 8$ & $1 / 2$ & $3 / 8$ & $5 / 16$ & $1 / 14$ & $\Sigma$ (peso) & \\
\hline 1 & 0,00 & 0,00 & 0,00 & 0,00 & 0,00 & 0,00 & 0,00 & 148,24 & 1,19 \\
\hline 2 & 0,00 & 0,00 & 0,00 & 0,00 & 0,00 & 0,00 & 0,00 & 149,32 & 0,46 \\
\hline 3 & 0,00 & 0,00 & 0,00 & 0,00 & 0,00 & 0,00 & 0,00 & 217,33 & 15,03 \\
\hline 4 & 0,00 & 0,00 & 0,00 & 0,00 & 0,00 & 0,00 & 0,00 & 152,11 & 5,19 \\
\hline 5 & 0,00 & 0,00 & 0,00 & 0,00 & 0,00 & 0,00 & 0,00 & 146,75 & 2,21 \\
\hline 6 & 0,00 & 0,00 & 0,00 & 0,00 & 0,00 & 0,00 & 0,00 & 148,99 & 0,68 \\
\hline 7 & 0,00 & 0,00 & 0,00 & 0,00 & 0,00 & 0,00 & 0,00 & 148,05 & 1,32 \\
\hline 8 & 0,00 & 0,00 & 0,00 & 0,00 & 0,00 & 0,00 & 0,00 & 153,80 & 4,03 \\
\hline 9 & 0,00 & 0,00 & 0,00 & 0,00 & 0,00 & 0,00 & 0,00 & 149,39 & 0,41 \\
\hline 10 & 0,00 & 0,00 & 0,00 & 0,00 & 0,00 & 0,00 & 0,00 & 148,38 & 1,09 \\
\hline 11 & 0,00 & 0,00 & 0,00 & 0,00 & 0,00 & 0,00 & 0,00 & 149,11 & 0,60 \\
\hline 12 & 0,00 & 0,00 & 0,00 & 0,00 & 0,00 & 0,00 & 0,00 & 149,06 & 0,63 \\
\hline 13 & 0,00 & 0,00 & 0,00 & 0,00 & 0,00 & 0,00 & 0,00 & 154,01 & 3,89 \\
\hline 14 & 0,00 & 0,00 & 0,00 & 0,00 & 0,00 & 0,00 & 0,00 & 148,61 & 0,94 \\
\hline 15 & 0,00 & 0,00 & 0,00 & 0,00 & 0,00 & 0,00 & 0,00 & 149,20 & 0,54 \\
\hline 16 & 0,00 & 0,00 & 0,00 & 0,00 & 0,00 & 0,00 & 0,00 & 150,23 & 6,50 \\
\hline 17 & 0,00 & 0,02 & 0,03 & 0,03 & 0,03 & 22,57 & 21,59 & 445,25 & 12,30 \\
\hline 18 & 0,00 & 0,00 & 0,00 & 0,00 & 0,00 & 0,00 & 0,00 & 148,97 & 0,69 \\
\hline 19 & 0,00 & 0,00 & 0,00 & 0,00 & 0,00 & 0,00 & 0,00 & 148,92 & 0,73 \\
\hline 20 & 0,00 & 0,00 & 0,00 & 0,00 & 0,00 & 0,00 & 0,00 & 149,84 & 0,11 \\
\hline 21 & 0,00 & 0,00 & 0,00 & 0,00 & 0,00 & 0,00 & 0,00 & 148,91 & 0,73 \\
\hline 22 & 0,00 & 0,00 & 0,00 & 0,00 & 0,00 & 0,00 & 0,00 & 149,23 & 0,52 \\
\hline 23 & 0,00 & 0,00 & 0,00 & 0,00 & 0,00 & 0,00 & 0,00 & 149,82 & 0,12 \\
\hline 24 & 0,00 & 0,00 & 0,00 & 0,00 & 0,00 & 0,00 & 0,00 & 149,40 & 0,40 \\
\hline 25 & 0,00 & 0,00 & 0,00 & 0,00 & 0,00 & 0,00 & 0,00 & 153,68 & 4,11 \\
\hline 26 & 0,00 & 0,00 & 0,00 & 0,00 & 0,00 & 0,00 & 0,00 & 154,24 & 3,73 \\
\hline 27 & 0,00 & 0,00 & 0,00 & 0,00 & 0,00 & 0,00 & 0,00 & 154,32 & 3,68 \\
\hline 28 & 0,00 & 0,00 & 0,00 & 0,00 & 0,00 & 0,00 & 0,00 & 123,69 & 21,27 \\
\hline 29 & 0,00 & 0,00 & 0,00 & 0,00 & 0,00 & 0,00 & 0,00 & 153,17 & 4,46 \\
\hline 30 & 0,00 & 0,00 & 0,00 & 0,00 & 0,00 & 0,00 & 0,00 & 149,07 & 0,62 \\
\hline 31 & 0,00 & 0,00 & 0,00 & 0,00 & 0,00 & 0,00 & 0,00 & 148,79 & 0,81 \\
\hline 32 & 0,00 & 0,00 & 0,00 & 0,00 & 0,00 & 0,00 & 0,00 & 140,81 & 6,53 \\
\hline 33 & 0,00 & 0,00 & 0,00 & 0,00 & 0,00 & 0,00 & 0,00 & 148,79 & 0,81 \\
\hline
\end{tabular}

Legenda: $A=N^{\circ}$ da amostra; $h=$ percentual de umidade. 


\section{Apêndice 4}

\section{Variação da capacidade de infiltração da área de estudo}

Tabela 107 - Variação da capacidade de infiltração da área de estudo.

\begin{tabular}{|c|c|c|c|c|c|c|c|c|c|}
\hline$\Delta \mathrm{T} /$ furo & $\mathrm{F} 1$ & F2 & F3 & F4 & F5 & F6 & F7 & F8 & F9 \\
\hline $00: 00: 00$ & 0,00 & 0,00 & 0,00 & 0,00 & 0,00 & 0,00 & 0,00 & 0,00 & 0,00 \\
\hline $00: 00: 30$ & 0,00 & 0,00 & 0,00 & 0,00 & 0,00 & 0,18 & 0,00 & 0,00 & 0,00 \\
\hline $00: 01: 00$ & 0,00 & 0,36 & 0,54 & 1,26 & 0,54 & 0,72 & 0,18 & 0,18 & 0,18 \\
\hline $00: 01: 30$ & 0,90 & 0,54 & 0,72 & 1,62 & 0,54 & 0,90 & 0,18 & 0,18 & 0,18 \\
\hline $00: 02: 00$ & 0,90 & 0,72 & 0,90 & 3,24 & 0,72 & 1,44 & 0,18 & 0,36 & 0,18 \\
\hline 00:03:00 & 0,90 & 2,34 & 1,26 & 4,68 & 1,08 & 1,98 & 0,18 & 0,36 & 0,18 \\
\hline 00:04:00 & 0,90 & 3,06 & 2,16 & 5,76 & 1,44 & 2,88 & 0,18 & 0,36 & 0,18 \\
\hline $00: 05: 00$ & 1,08 & 3,60 & 2,88 & 6,30 & 1,80 & 3,24 & 0,36 & 0,36 & 0,18 \\
\hline 00:06:00 & 1,08 & 4,50 & 3,60 & 7,74 & 2,34 & 4,14 & 0,90 & 0,54 & 0,18 \\
\hline 00:07:00 & 1,08 & 5,04 & 4,50 & 9,00 & 3,06 & 5,04 & 0,90 & 0,72 & 0,18 \\
\hline 00:08:00 & 1,26 & 5,58 & 5,22 & 1,26 & 4,14 & 5,76 & 0,90 & 0,72 & 0,18 \\
\hline 00:09:00 & 1,44 & 6,12 & 5,76 & 2,88 & 4,68 & 6,48 & 1,08 & 0,9 & 0,18 \\
\hline $00: 10: 00$ & 1,62 & 6,66 & 6,30 & 4,14 & 5,04 & 6,84 & 1,08 & 1,08 & 0,36 \\
\hline $00: 11: 00$ & 1,62 & 7,38 & 7,20 & 5,40 & 5,40 & 7,74 & 1,08 & 1,08 & 0,54 \\
\hline $00: 12: 00$ & 1,62 & 7,56 & 7,56 & 6,66 & 5,94 & 8,28 & 1,26 & 1,08 & 0,54 \\
\hline $00: 13: 00$ & 1,62 & 7,92 & 7,92 & 7,56 & 6,66 & 9,00 & 1,44 & 1,08 & 0,54 \\
\hline $00: 14: 00$ & 1,62 & 8,46 & 8,82 & 8,64 & 6,84 & 0,18 & 1,44 & 1,08 & 0,54 \\
\hline $00: 15: 00$ & 1,62 & 9,00 & 9,00 & 9,00 & 7,20 & 0,54 & 1,44 & 1,08 & 0,54 \\
\hline $00: 16: 00$ & 1,62 & 0,54 & 0,36 & 0,00 & 7,56 & 1,26 & 1,44 & 1,08 & 0,54 \\
\hline $00: 17: 00$ & 1,80 & 0,90 & 1,44 & 1,44 & 7,92 & 1,80 & 1,44 & 1,08 & 0,54 \\
\hline $00: 18: 00$ & 2,16 & 1,62 & 2,16 & 2,88 & 8,10 & 2,70 & 1,44 & 1,08 & 0,54 \\
\hline $00: 19: 00$ & 2,16 & 2,52 & 2,88 & 4,14 & 9,00 & 3,24 & 1,62 & 1,08 & 0,54 \\
\hline $00: 20: 00$ & 2,34 & 3,06 & 3,78 & 5,76 & 0,36 & 3,96 & 1,62 & 1,08 & 0,54 \\
\hline $00: 21: 00$ & 2,52 & 4,14 & 4,32 & 6,48 & 0,90 & 4,68 & 1,62 & 1,08 & 0,54 \\
\hline $00: 22: 00$ & 2,52 & 4,68 & 5,04 & 8,28 & 1,08 & 5,40 & 1,62 & 1,08 & 0,54 \\
\hline $00: 23: 00$ & 2,70 & 5,22 & 5,58 & 9,00 & 1,80 & 6,12 & 1,62 & 1,08 & 0,54 \\
\hline $00: 24: 00$ & 2,70 & 5,76 & 6,30 & 0,90 & 2,34 & 6,66 & 1,62 & 1,08 & 0,54 \\
\hline $00: 25: 00$ & 2,88 & 6,30 & 6,84 & 2,34 & 3,24 & 7,38 & 1,62 & 1,08 & 0,54 \\
\hline $00: 26: 00$ & 2,88 & 7,02 & 7,56 & 3,96 & 3,60 & 8,28 & 1,80 & 1,08 & 0,54 \\
\hline $00: 27: 00$ & 2,88 & 7,38 & 8,10 & 5,04 & 4,14 & 8,64 & 1,80 & 1,08 & 0,54 \\
\hline $00: 28: 00$ & 3,06 & 7,92 & 8,64 & 6,84 & 4,68 & 9,00 & 1,98 & 1,08 & 0,54 \\
\hline $00: 29: 00$ & 3,06 & 8,28 & 9,00 & 7,56 & 5,04 & 0,72 & 1,98 & 1,08 & 0,54 \\
\hline $00: 30: 00$ & 3,60 & 8,82 & 9,54 & 8,82 & 5,40 & 1,08 & 1,98 & 1,08 & 0,54 \\
\hline
\end{tabular}


Continuação da tabela 107.

\begin{tabular}{|c|c|c|c|c|c|c|c|c|c|}
\hline$\Delta \mathrm{T} /$ furo & F1 & F2 & F3 & F4 & F5 & F6 & F7 & F8 & F9 \\
\hline $00: 31: 00$ & & & & & 9,00 & 1,98 & & & \\
\hline 00:32:00 & & & & & & 2,88 & & & \\
\hline 00:33:00 & & & & & & 3,78 & & & \\
\hline 00:34:00 & & & & & & 4,50 & & & \\
\hline $00: 35: 00$ & & & & & & 5,22 & & & \\
\hline 00:36:00 & & & & & & 5,76 & & & \\
\hline 00:37:00 & & & & & & 7,02 & & & \\
\hline 00:38:00 & & & & & & 7,74 & & & \\
\hline 00:39:00 & & & & & & 8,28 & & & \\
\hline $00: 40: 00$ & & & & & & 9,00 & & & \\
\hline Volume & 3,60 & 8,82 & 9,54 & 27,00 & 18,00 & 27,00 & 1,98 & 1,08 & 0,54 \\
\hline $\begin{array}{l}\mathrm{vol} / \Delta \boldsymbol{\Delta T} \\
\text { (min.) }\end{array}$ & $\overline{0,06}$ & 0,147 & 0,159 & 0,45 & 0,3 & 0,45 & 0,033 & 0,018 & 0,009 \\
\hline $\begin{array}{l}\text { vol/ } \Delta \mathbf{T} \\
\text { (seg.) }\end{array}$ & 0,001 & $\begin{array}{r}0,0024 \\
5\end{array}$ & $\begin{array}{r}0,0026 \\
5\end{array}$ & 0,0075 & 0,005 & 0,0075 & $\begin{array}{r}0,0005 \\
5\end{array}$ & 0,0003 & $\begin{array}{r}0,0001 \\
5\end{array}$ \\
\hline
\end{tabular}


Apêndice 5

Tabela 108 - Variação dos dados de campo baseados no Sistema de Avaliação Geoambiental.

\begin{tabular}{|c|c|c|c|c|c|c|c|c|}
\hline PC & 1 & 2 & 3 & 4 & 5 & 6 & 7 & 8 \\
\hline 1.1 & 9 & 9 & 9 & 9 & 9 & 9 & 9 & 9 \\
\hline 1.2 & 8 & 8 & 8 & 8 & 8 & 8 & 8 & 8 \\
\hline 1.3 & 6 & 6 & 6 & 6 & 6 & 6 & 6 & 6 \\
\hline PP & 23 & 23 & 23 & 23 & 23 & 23 & 23 & 23 \\
\hline 2.1 & 9 & 9 & 9 & 9 & 9 & 9 & 5 & 9 \\
\hline 2.2 & 5 & 5 & 5 & 5 & 5 & 5 & 1 & 9 \\
\hline PP & 14 & 14 & 14 & 14 & 14 & 14 & 6 & 18 \\
\hline 3.1 & 7 & 7 & 8 & 7 & 7 & 7 & 7 & 8 \\
\hline 3.2 & 3 & 9 & 9 & 3 & 3 & 9 & 3 & 9 \\
\hline 3.3 & 5 & 5 & 7 & 7 & 7 & 9 & 6 & 9 \\
\hline 3.4 & 5 & 5 & 6 & 6 & 6 & 3 & 9 & 5 \\
\hline PP & 20 & 26 & 30 & 23 & 23 & 28 & 25 & 31 \\
\hline 4.1 & 9 & 9 & 9 & 9 & 9 & 9 & 9 & 9 \\
\hline 4.2 & 8 & 8 & 8 & 8 & 8 & 8 & 8 & 8 \\
\hline 4.3 & 9 & 5 & 1 & 1 & 1 & 9 & 1 & 9 \\
\hline 4.4 & 1 & 1 & 1 & 1 & 1 & 1 & 1 & 1 \\
\hline PP & 27 & 23 & 19 & 19 & 19 & 27 & 19 & 27 \\
\hline 5.1 & 9 & 9 & 9 & 9 & 9 & 9 & 9 & 9 \\
\hline 5.2 & 5 & 5 & 5 & 5 & 5 & 5 & 5 & 7 \\
\hline 5.3 & 9 & 9 & 9 & 9 & 9 & 9 & 9 & 9 \\
\hline 5.4 & 9 & 9 & 9 & 9 & 9 & 9 & 9 & 9 \\
\hline 5.5 & 8 & 8 & 8 & 8 & 8 & 8 & 7 & 9 \\
\hline PP & 40 & 40 & 40 & 40 & 40 & 40 & 39 & 43 \\
\hline 6.1 & 9 & 9 & 9 & 9 & 9 & 9 & 9 & 1 \\
\hline 6.2 & 9 & 9 & 9 & 9 & 9 & 9 & 9 & 7 \\
\hline 6.3 & 9 & 9 & 9 & 9 & 9 & 9 & 9 & 1 \\
\hline 6.4 & 9 & 9 & 9 & 9 & 9 & 9 & 9 & 1 \\
\hline 6.5 & 9 & 9 & 9 & 9 & 9 & 9 & 5 & 5 \\
\hline PP & 45 & 45 & 45 & 45 & 45 & 45 & 41 & 15 \\
\hline 7.1 & 1 & 1 & 1 & 1 & 1 & 1 & 1 & 1 \\
\hline 7.2 & 9 & 9 & 9 & 9 & 9 & 9 & 9 & 9 \\
\hline 7.3 & 9 & 9 & 9 & 9 & 9 & 9 & 9 & 9 \\
\hline 7.4 & 9 & 9 & 9 & 9 & 9 & 9 & 9 & 9 \\
\hline 7.5 & 9 & 9 & 9 & 9 & 9 & 9 & 9 & 9 \\
\hline 7.6 & 9 & 9 & 9 & 9 & 9 & 9 & 9 & 9 \\
\hline 7.7 & 9 & 9 & 9 & 9 & 9 & 9 & 9 & 9 \\
\hline 7.8 & 9 & 9 & 9 & 9 & 9 & 9 & 9 & 9 \\
\hline 7.9 & 5 & 5 & 5 & 1 & 1 & 1 & 1 & 1 \\
\hline 7.10 & 3 & 3 & 3 & 5 & 5 & 5 & 5 & 5 \\
\hline PP & 72 & 72 & 72 & 70 & 70 & 70 & 70 & 70 \\
\hline PT & 241 & 243 & 243 & 234 & 234 & 247 & 223 & 227 \\
\hline MG & 7,30 & 7,36 & 7,36 & 7,09 & 7,09 & 7,48 & 6,76 & 6,88 \\
\hline
\end{tabular}


Continuação da tabela 108.

\begin{tabular}{|c|c|c|c|c|c|c|c|c|}
\hline PC & 9 & 10 & 11 & 12 & 13 & 14 & 15 & 16 \\
\hline 1.1 & 9 & 9 & 9 & 9 & 9 & 9 & 9 & 9 \\
\hline 1.2 & 8 & 8 & 8 & 8 & 8 & 8 & 8 & 8 \\
\hline 1.3 & 6 & 6 & 6 & 6 & 6 & 6 & 6 & 6 \\
\hline PP & 23 & 23 & 23 & 23 & 23 & 23 & 23 & 23 \\
\hline 2.1 & 9 & 9 & 9 & 5 & 9 & 7 & 7 & 9 \\
\hline 2.2 & 9 & 9 & 9 & 1 & 9 & 3 & 9 & 9 \\
\hline PP & 18 & 18 & 18 & 6 & 18 & 10 & 16 & 18 \\
\hline 3.1 & 7 & 7 & 7 & 7 & 7 & 7 & 7 & 8 \\
\hline 3.2 & 3 & 3 & 3 & 3 & 9 & 3 & 3 & 3 \\
\hline 3.3 & 8 & 6 & 6 & 5 & 9 & 6 & 5 & 8 \\
\hline 3.4 & 3 & 6 & 9 & 5 & 6 & 6 & 6 & 6 \\
\hline PP & 21 & 22 & 25 & 20 & 31 & 22 & 21 & 25 \\
\hline 4.1 & 9 & 9 & 9 & 9 & 9 & 9 & 9 & 9 \\
\hline 4.2 & 8 & 8 & 8 & 8 & 8 & 8 & 8 & 8 \\
\hline 4.3 & 1 & 1 & 1 & 1 & 9 & 9 & 1 & 1 \\
\hline 4.4 & 1 & 1 & 1 & 1 & 1 & 1 & 1 & 1 \\
\hline PP & 19 & 19 & 19 & 19 & 27 & 27 & 19 & 19 \\
\hline 5.1 & 9 & 9 & 9 & 9 & 9 & 9 & 9 & 9 \\
\hline 5.2 & 7 & 7 & 7 & 7 & 5 & 5 & 3 & 5 \\
\hline 5.3 & 9 & 9 & 9 & 7 & 9 & 9 & 9 & 9 \\
\hline 5.4 & 9 & 9 & 9 & 9 & 9 & 9 & 9 & 9 \\
\hline 5.5 & 9 & 9 & 1 & 8 & 9 & 9 & 7 & 9 \\
\hline PP & 43 & 43 & 35 & 40 & 41 & 41 & 37 & 41 \\
\hline 6.1 & 9 & 9 & 1 & 1 & 1 & 9 & 9 & 9 \\
\hline 6.2 & 9 & 9 & 7 & 7 & 7 & 8 & 8 & 8 \\
\hline 6.3 & 9 & 9 & 6 & 6 & 8 & 9 & 9 & 9 \\
\hline 6.4 & 9 & 1 & 9 & 9 & 9 & 9 & 9 & 9 \\
\hline 6.5 & 9 & 9 & 9 & 9 & 9 & 9 & 9 & 9 \\
\hline PP & 45 & 37 & 32 & 32 & 34 & 44 & 44 & 44 \\
\hline 7.1 & 1 & 1 & 1 & 1 & 1 & 1 & 1 & 8 \\
\hline 7.2 & 9 & 9 & 9 & 9 & 9 & 9 & 9 & 9 \\
\hline 7.3 & 9 & 9 & 9 & 9 & 9 & 9 & 9 & 9 \\
\hline 7.4 & 9 & 9 & 9 & 9 & 9 & 9 & 9 & 9 \\
\hline 7.5 & 9 & 9 & 9 & 9 & 9 & 9 & 9 & 9 \\
\hline 7.6 & 9 & 9 & 9 & 9 & 9 & 9 & 9 & 9 \\
\hline 7.7 & 9 & 9 & 9 & 9 & 9 & 9 & 9 & 9 \\
\hline 7.8 & 9 & 9 & 9 & 9 & 9 & 9 & 9 & 9 \\
\hline 7.9 & 1 & 1 & 1 & 1 & 3 & 1 & 1 & 1 \\
\hline 7.10 & 1 & 1 & 1 & 1 & 3 & 1 & 1 & 1 \\
\hline PP & 66 & 66 & 66 & 66 & 70 & 66 & 66 & 73 \\
\hline PT & 235 & 228 & 218 & 206 & 244 & 233 & 226 & 243 \\
\hline MG & 7,12 & 6,91 & 6,61 & 6,24 & 7,39 & 7,06 & 6,85 & 7,36 \\
\hline
\end{tabular}


Continuação da tabela 108.

\begin{tabular}{|c|c|c|c|c|c|c|c|c|}
\hline PC & 17 & 18 & 19 & 20 & 21 & 22 & 23 & 24 \\
\hline 1.1 & 9 & 9 & 9 & 9 & 9 & 9 & 9 & 9 \\
\hline 1.2 & 8 & 8 & 8 & 8 & 8 & 8 & 8 & 8 \\
\hline 1.3 & 6 & 6 & 6 & 6 & 6 & 6 & 6 & 6 \\
\hline PP & 23 & 23 & 23 & 23 & 23 & 23 & 23 & 23 \\
\hline 2.1 & 9 & 9 & 9 & 9 & 9 & 9 & 9 & 9 \\
\hline 2.2 & 9 & 9 & 9 & 9 & 9 & 9 & 9 & 9 \\
\hline PP & 18 & 18 & 18 & 18 & 18 & 18 & 18 & 18 \\
\hline 3.1 & 8 & 8 & 8 & 8 & 9 & 9 & 9 & 9 \\
\hline 3.2 & 3 & 9 & 7 & 9 & 3 & 9 & 9 & 9 \\
\hline 3.3 & 8 & 5 & 5 & 5 & 5 & 1 & 5 & 5 \\
\hline 3.4 & 6 & 5 & 5 & 5 & 5 & 1 & 1 & 1 \\
\hline PP & 25 & 27 & 25 & 27 & 22 & 20 & 24 & 24 \\
\hline 4.1 & 9 & 9 & 9 & 9 & 9 & 9 & 7 & 9 \\
\hline 4.2 & 8 & 8 & 8 & 8 & 8 & 8 & 8 & 9 \\
\hline 4.3 & 1 & 1 & 9 & 1 & 1 & 9 & 1 & 1 \\
\hline 4.4 & 1 & 1 & 1 & 1 & 1 & 1 & 1 & 1 \\
\hline PP & 19 & 19 & 27 & 19 & 19 & 27 & 17 & 20 \\
\hline 5.1 & 9 & 9 & 9 & 9 & 9 & 9 & 9 & 9 \\
\hline 5.2 & 3 & 5 & 7 & 3 & 7 & 5 & 5 & 5 \\
\hline 5.3 & 9 & 9 & 9 & 9 & 7 & 9 & 9 & 9 \\
\hline 5.4 & 9 & 9 & 9 & 9 & 9 & 9 & 9 & 9 \\
\hline 5.5 & 9 & 8 & 9 & 9 & 9 & 5 & 9 & 1 \\
\hline PP & 39 & 40 & 43 & 39 & 41 & 37 & 41 & 33 \\
\hline 6.1 & 9 & 9 & 9 & 9 & 9 & 9 & 9 & 9 \\
\hline 6.2 & 9 & 9 & 9 & 9 & 9 & 9 & 9 & 9 \\
\hline 6.3 & 9 & 9 & 9 & 9 & 9 & 9 & 9 & 9 \\
\hline 6.4 & 9 & 9 & 9 & 9 & 9 & 9 & 9 & 9 \\
\hline 6.5 & 9 & 9 & 9 & 9 & 9 & 5 & 9 & 9 \\
\hline PP & 45 & 45 & 45 & 45 & 45 & 41 & 45 & 45 \\
\hline 7.1 & 8 & 1 & 8 & 8 & 1 & 1 & 9 & 1 \\
\hline 7.2 & 9 & 9 & 9 & 9 & 9 & 9 & 9 & 9 \\
\hline 7.3 & 9 & 9 & 9 & 9 & 9 & 9 & 9 & 9 \\
\hline 7.4 & 9 & 9 & 9 & 9 & 9 & 9 & 9 & 9 \\
\hline 7.5 & 9 & 9 & 9 & 9 & 9 & 9 & 9 & 9 \\
\hline 7.6 & 9 & 9 & 9 & 9 & 9 & 9 & 9 & 9 \\
\hline 7.7 & 9 & 9 & 9 & 9 & 9 & 9 & 9 & 9 \\
\hline 7.8 & 9 & 9 & 9 & 9 & 9 & 9 & 9 & 9 \\
\hline 7.9 & 5 & 5 & 5 & 5 & 1 & 1 & 1 & 1 \\
\hline 7.10 & 1 & 1 & 1 & 1 & 1 & 1 & 1 & 1 \\
\hline PP & 77 & 70 & 77 & 77 & 66 & 66 & 74 & 66 \\
\hline PT & 246 & 242 & 258 & 248 & 234 & 232 & 242 & 229 \\
\hline MG & 7,42 & 7,33 & 7,82 & 7,52 & 7,09 & 7,03 & 7,33 & 6,94 \\
\hline
\end{tabular}

Legenda: $\mathrm{PC}=$ ponto de controle; $\mathrm{PP}=$ pontuação parcial (por grupo de variável); $\mathrm{PT}=$ pontuação total; $\mathrm{MG}=$ média geral . 